\title{
Az alkotmány stabilitását védő garanciák
}

Doktori $(\mathrm{PhD})$ értekezés

Készítette: Dr. Szakály Zsuzsa

(Kézirat lezárva: 2018. március 11.)

Témavezetö:

Prof. Dr. Trócsányi László, PhD.

Szegedi Tudományegyetem

Állam- és Jogtudományi Doktori Iskola

Szeged, 2018. 


\section{Tartalomjegyzék}

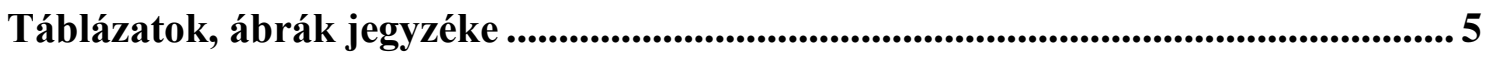

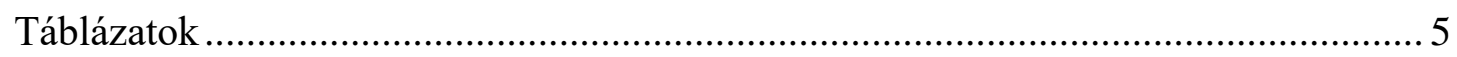

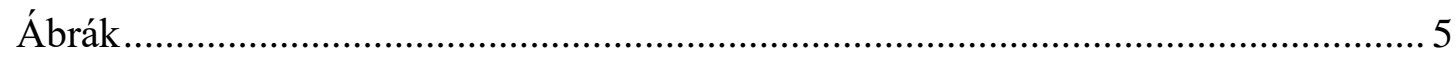

Rövidítések jegyzéke..................................................................................................6

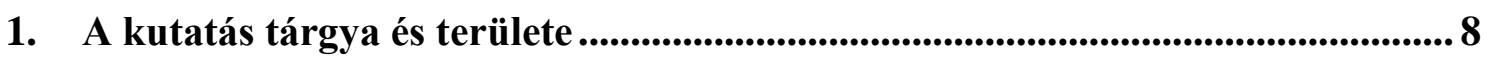

1.1 Az alkotmány stabilitása - az alkotmány stabilitását védő garanciák .............. 8

1.1.1 Az alkotmányfejlődést érő hatások ................................................... 8

1.1.2 A vizsgálat határvonalai és szempontjai ............................................. 10

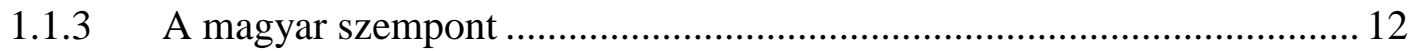

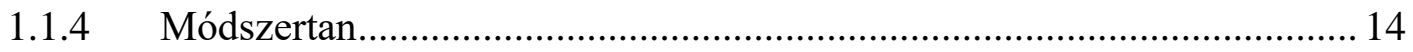

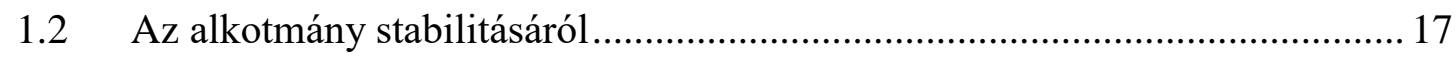

1.2.1 Miért nem alkotmányos stabilitás? ................................................. 17

1.2.2 Miért nem alkotmányosság? ......................................................... 19

1.2.3 Miért nem jogállamiság? ................................................................. 21

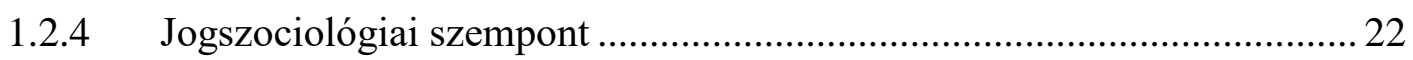

1.2.5 Az Európai Unió joga és a nemzetközi jog? .......................................... 23

1.2.6 Az alkotmány stabilitásának szerepe ................................................ 23

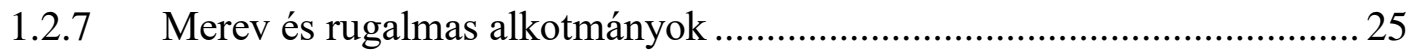

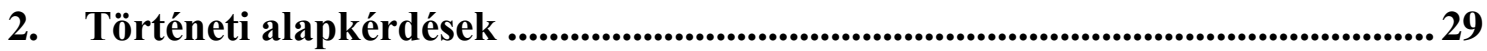

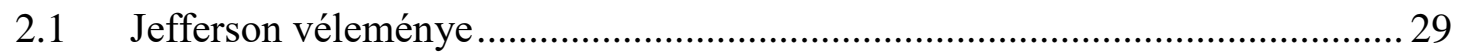

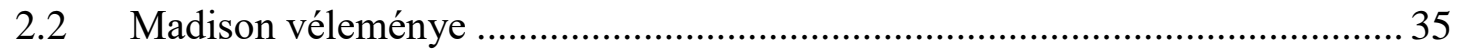

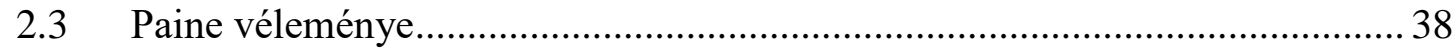

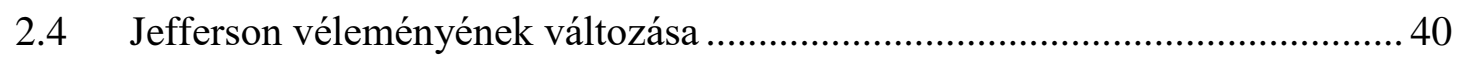

3. A Velencei Bizottság értelmezése az alkotmány stabilitásáról .......................... 43

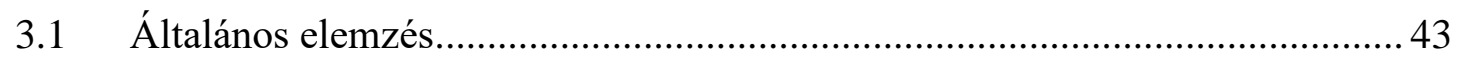

3.2 A Velencei Bizottság véleménye néhány konkrét ügyben............................. 46 
3.3 A Velencei Bizottság a magyar Alaptörvényről 48

4. Alkotmányozás és alkotmánymódosítás elhatárolása stabilitási szempontból 52 4.1 Alkotmányozás és alkotmánymódosítás elválasztása a hazai alkotmányos rendszerben

5. A sziklára épített házról, vagyis az alkotmány stabilitásáról szóló elméletekről 61

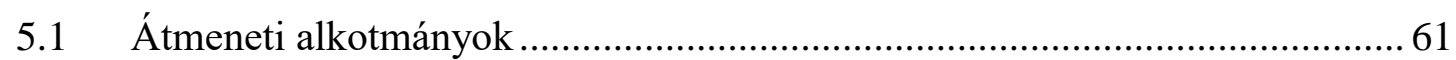

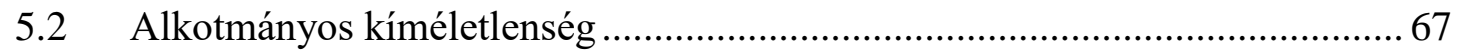

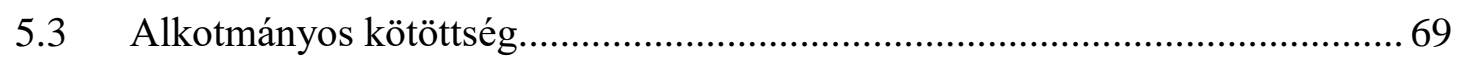

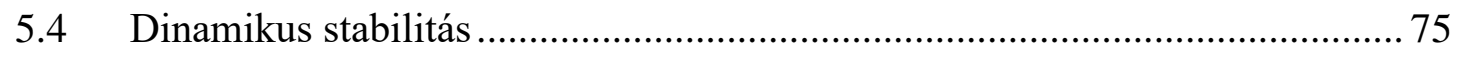

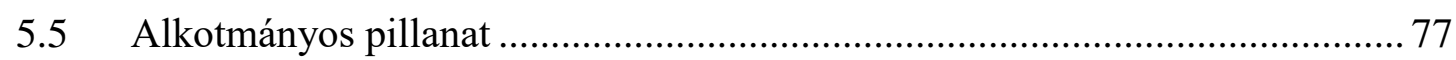

6. Az alkotmánymódosítási eljárás típusai az Európai Unió tagállamaiban ....... 82

6.1 Az alkotmány stabilitása az eljárási eszközök szempontjából........................ 82

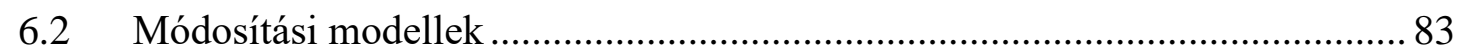

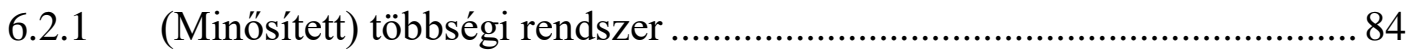

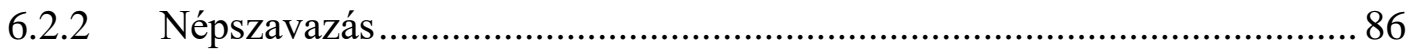

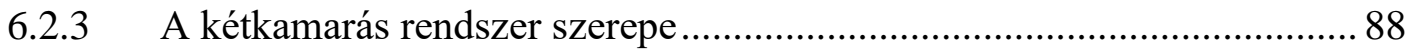

6.2.4 Kezdeményezési jog alapján történő megkülönböztetés ......................... 89

6.2.5 Késleltetési eljárások .................................................................... 90

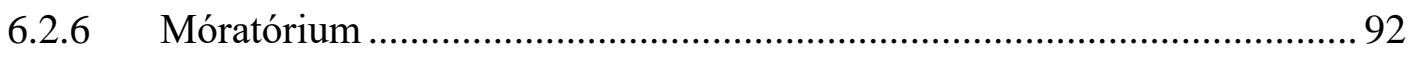

6.2.7 Az alkotmányozó nemzetgyülés modellje .......................................... 93

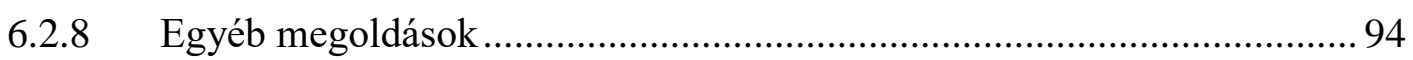

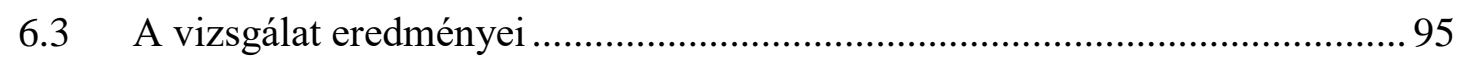

7. Örökkévaló-e a stabilitás? Az örökkévalósági klauzulák az alkotmány

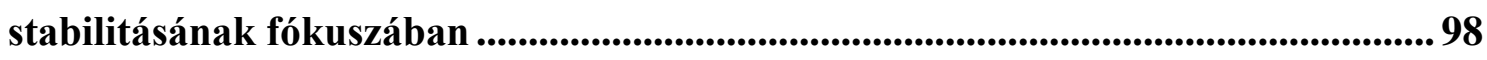

7.1 Az örökkévalósági klauzula fogalmi keretei............................................. 98

7.2 Örökkévalósági klauzulák az Európai Unió tagállamainak alkotmányaiban. 102

7.2.1 Az államforma 104 


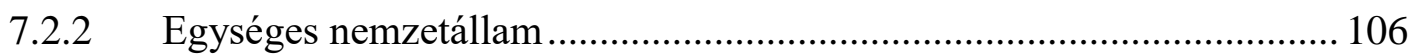

7.2.3 A hatalmi ágak elválasztása .................................................................... 106

7.2.4 Az alapjogok védelme ………………………………………………... 107

7.2.5 Hatalomgyakorlás és jogállamiság ........................................................ 108

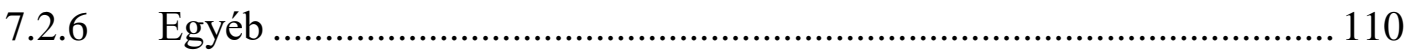

7.3 Az örökkévalósági klauzulák szerepe az alkotmány stabilitásának védelmében 110

8. Múlt és jövő az Európai Unió tagállamaiban az alkotmány preambulumában 113

8.1 A múlt az EU tagállamok alkotmányainak preambulumaiban ...................... 115

8.2 A jövő az EU tagállamok alkotmányainak preambulumaiban......................... 119

8.3 A Nemzeti Hitvallás múltra és jövőre utaló rendelkezései ............................. 121

8.3.1 A preambulum hatása az értelmezési gyakorlatra ……………………... 124

8.4 A preambulum múltra és jövőre vonatkozó rendelkezéseinek jelentősége összegzés

9. A történeti alkotmány vívmányai az Alaptörvényben ........................................... 132

9.1 A történeti alkotmány .................................................................................... 133

9.2 A történeti alkotmány vívmányainak tartalma ............................................... 136

9.3 Az alkotmányos identitás .............................................................................. 144

9.4 Lehetséges kapcsolódási pont az alkotmányos identitás és a történeti alkotmány vívmányai között.................................................................................... 147

10. A jövő elkezdődött? Az intergenerációs igazságosság és az alkotmányok stabilitása ...................................................................................................................................... 153

10.1 Az intergenerációs igazságosság.............................................................. 154

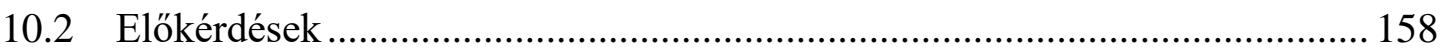

10.3 Az alkotmány stabilitása és a jövő generációk jogai ...................................... 163

10.4 A jövő generációk érdekeinek védelmének megjelenési formái...................... 169

11. Alkotmányellenes alkotmánymódosítások alkotmányossági vizsgálata ..... 175 


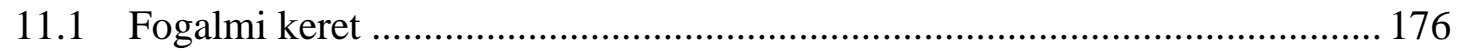

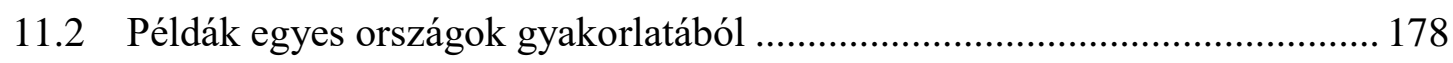

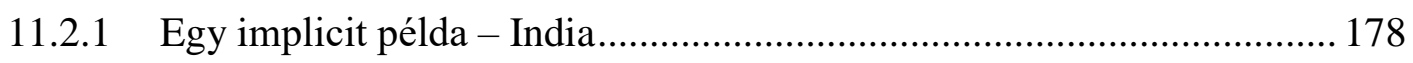

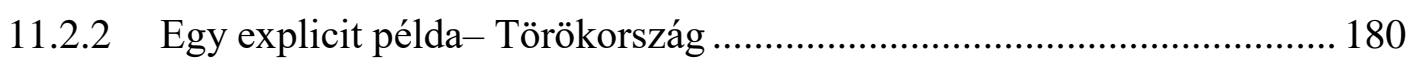

11.2.3 Egy ,elszalasztott lehetőség” - Magyarország...................................... 182

12. Következtetések és hasznosítási javaslatok ............................................ 189

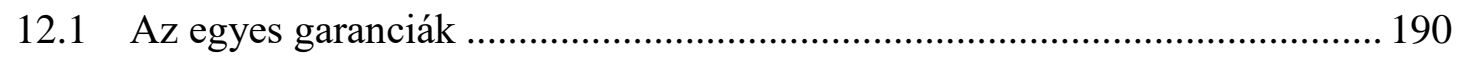

12.1.1 Eljárási eszközök .................................................................... 191

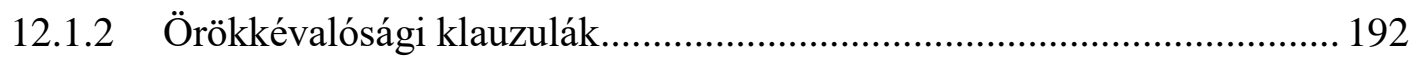

12.1.3 A preambulumok múltra és jövőre utaló rendelkezései......................... 193

12.1.4 A történeti alkotmány vívmányai ........................................................ 193

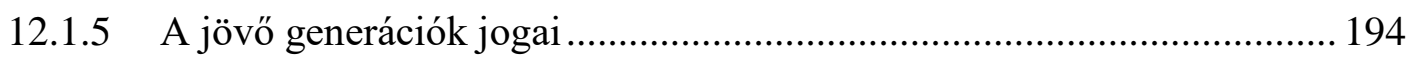

12.1.6 Alkotmányellenes alkotmánymódosítások alkotmányossági vizsgálata 195

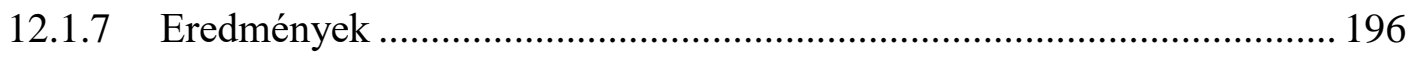

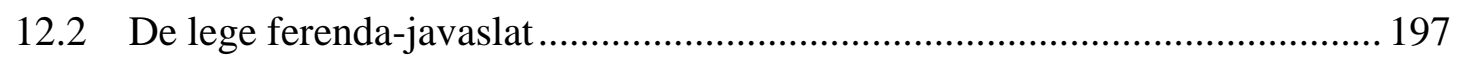

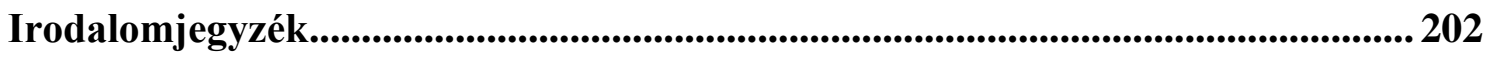

Szülői szavazati jog - érvek pro és kontra http://alkotmany.reblog.hu/szuloiszavazatijog 235

Hivatkozott jogszabályok, jogesetek jegyzéke........................................................... 236

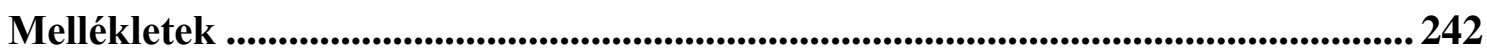




\section{Táblázatok, ábrák jegyzéke}

\section{Táblázatok}

1. táblázat. A vizsgált garanciák jellemzése.

201

2. táblázat. Az egyes eljárási eszközök előfordulása az Európai Unió tagállamainak alkotmányaiban. 243

3. táblázat. A múlt és a jövő megjelenése az Európai Unió tagállamainak alkotmányaiban. 244

4. táblázat. A történeti alkotmány vívmányai és az örökkévalósági klauzulák közötti kapcsolódási pontok. 245

5. táblázat. Az örökkévalósági klauzulák megjelenése az Európai Unió tagállamainak alkotmányaiban. 248

\section{Ábrák}

1. ábra. Az egyes örökkévalósági klauzulák előfordulásnak gyakorisága 102

2. ábra. Az egyes eljárási eszközök előfordulásának gyakorisága az Európai Unió tagállamainak alkotmányaiban. 249 


\section{Rövidítések jegyzéke}

Alaptörvény: Magyarország Alaptörvénye (2011. április 25.)

Alkotmány: 1949. évi XX: törvény

VB: Jog a Demokráciáért Európai Bizottság

EU: Európai Unió

$\mathrm{AB}$ határozat: alkotmánybírósági határozat

ÁR: Átmeneti Rendelkezések 


\section{Köszönetnyilvánítás}

Elsőként szeretnék köszönetet mondani témavezetőmnek, Prof. Dr. Trócsányi Lászlónak, aki mindig segített irányba állítani a kutatást, és tanácsaival inspirálta a munkám.

A kollégák közül szeretném kiemelni dr. Tóth Judit tanszékvezető asszonyt, aki figyelemmel kísérte és hasznos tanácsaival előre vitte munkám alakulását. Emellett nagyon hálás vagyok dr. Sulyok Márton adjunktus úrnak, aki számtalan elméleti és gyakorlati kérdésben segítette előrehaladásom, és az eszmecseréink gyakran mutattak rá fontos kérdésekre.

Külön köszönet illeti dr. Chronowski Nóra tanszékvezető asszonyt és Prof. dr. Schanda Balázs egyetemi tanár urat, akik nagyban hozzájárultak dolgozatom fejlődéséhez.

Szeretném megköszönni a Szegedi Tudományegyetem Állam-és Jogtudományi Kara Alkotmányjogi Tanszékén minden kollégának, valamint az Igazságügyi Minisztérium Igazságügyi Szolgálatok Jogakadémiáján dolgozó kollégáimnak, hogy támogatták munkám, sokat tanultam tőlük, látóköröm szélesedett. Külön szeretném kiemelni dr. Siket Judit adjunktus asszonyt, aki mindig jó tanácsokkal látott el.

Köszönöm családomnak a támogatást, különösen férjemnek, aki végig élte velem az egész folyamatot, és mindig biztatott, hogy elérjem célom, remélem, tudtam viszonozni a saját disszertációjának elkészítése során. 


\section{A kutatás tárgya és területe}

„Semmi sem állandó, csak a változás maga.”

(Hérakleitosz)

\subsection{Az alkotmány stabilitása - az alkotmány stabilitását védő garanciák}

\subsubsection{Az alkotmányfejlődést érö hatások}

Az alkotmány egy ország „bibliájának” tekinthető, ${ }^{1}$ szerepe kiemelkedő egy demokratikus ország megfelelő müködésében, ${ }^{2}$ hiszen a hatalomgyakorlás módját, az adott ország államszervezetének alapjait, valamint az alapvető jogok körvonalait ebben a dokumentumban rögzítik. Az alkotmányok a további részletek tekintetében különböző mértékben eltérőek, hiszen nincs két ország, amelynek alkotmányos berendezkedése teljesen megegyező volna, ${ }^{3}$ valamint az adott alkotmányozó konkrét választásai is jelentős szerepet játszanak a végleges eredmény kialakulásában - pl. szerkezet, kiemelt tartalom, stb. - Emellett az alkotmány jelképes identitásának elemei általában megjelennek az alkotmányban (legtipikusabb a zászló és a címer). ${ }^{4}$

\footnotetext{
${ }^{1}$ KuKORELli István: Hány éves az Alaptörvény? A régi-új kérdése az Alaptörvényben. Gondolat Kiadó, Budapest, 2017 272. p.

${ }^{2}$ A szabály alóli kivétel lehet Nagy-Britannia, ahol nem fogadtak el kartális alkotmányt, ún. történeti alkotmány érvényesül, azonban az ország müködése ennek ellenére megfelel a demokratikus normáknak, ez is azt bizonyítja, hogy a kartális alkotmány és az alkotmányosság nem feltétlenül járnak mindig kéz a kézben, és a különböző időpontokban elfogadott, önálló jogszabályok összessége is alkothat ilyen rendszert, amelyben szintén megjelenhetnek az alktomány stabilitását erősítő garanciák, azonban ezek vizsgálata már szétfeszítené a dolgozat kereteit. Nem vitatva, hogy a történeti alkotmány is az alkotmány egy fajtája, jelen munka a kartális alkotmányokat vizsgálja, mert egy történeti alkotmány pontos szövegtartalmának meghatározása önmagában sem egyszerü feladat, a szerző erre nem vállalkozott.

3 Természetesen vannak olyan országok, melyek alkotmányát mintának tekintik, valamint az összehasonlító alkotmányjog megjelenése is a (vélhetően) jó példák átvételét segíti elö, de alkotmányos transzplant esetén is tekintettel kell lenni az adott ország egyedi jellemzőire.

A jogi transzplant-elmélet összefoglalóját lásd: SULYOK MÁRTON: Magánszféravédelem a tisztességes eljárásban - Az alapjogsértő bizonyitás összehasonlitó alkotmányjogi vizsgálata. PhD értekezés 144-154. pp.

Emellett a szovjet mintaalkotmányt számos ország átvette kényszerüségböl, nem is felelt meg egyedi igényeiknek. Magyarország esetében lásd: KOVÁCS IsTVÁN: Az alkotmányfejlődés elvi kérdései, In: KOVÁCS ISTVÁN (szerk.): Alkotmány és alkotmányosság, Akadémiai Kiadó, Budapest, 1989, 11.p.

${ }^{4}$ SMUK PÉTER: A szuverenitás jelképei és alkotmányos védelmük. MTA Law Working Papers 2014/37. 13. pp.; KUKORELLI ISTVÁN: Tradíció és modernizáció a magyar alkotmányjogban, Századvég Kiadó, Budapest, 2006. 23-26. pp.
} 
Figyelembe veendő továbbá a gyakorlati érvényesülés kérdése is, hiszen az alkotmányos szokások súlya olyan erős lehet, hogy akár desuetudo-ként is hathatnak az alkotmányba foglalt szabályokkal szemben. Elegendő csupán Ciprus hatályos alkotmányát megvizsgálni, amely hosszasan értekezik a görög-török arányok érvényesítéséről az államszervezet müködésében, bár a valóságban ezek a rendelkezések nem érvényesülnek. ${ }^{5}$

Az alkotmány különböző funkciókkal rendelkezik, amelyek más-más szerepben jelenítik meg, ${ }^{6}$ azonban e munka nem az egyes funkciókat vizsgálja, hanem azokat a garanciákat, amelyek segíthetik stabillá tenni magát az alkotmányt, hogy ezáltal jobban elláthassa funkcióit.

Az első modern értelemben vett alkotmányok elfogadása a XVIII. század végén történt meg. Az első francia, valamint az amerikai alkotmány úttörő szerepet töltött be annak a képnek a kialakításában, ahogy ma látjuk, szemléljük az alkotmányokat. Előtte nem volt jellemző az állami élet alapjainak egyetlen dokumentumban való rögzítése, ahogyan napjainkban is lehetséges demokratikus müködés alkotmány nélkül, akárcsak diktatórikus működés hatályos alkotmánnyal. ${ }^{7}$

Franciaország és az USA példáját néhány európai ország követte a XIX. században, mint például Norvégia (1814), Belgium (1830). Általánosan elterjedtté az alkotmányozás Európában csak az első világháború után vált, a létrejövő új államok alkotmányozásba kezdtek, és a többi kontinensen is terjedni kezdett az alkotmányozás. ${ }^{8}$ A második világháború után a tragikus tapasztalatok hatására, valamint a gyarmati rendszer megszünésével az alkotmányozás szükségessége más országokban is megmutatkozott.

Ha megvizsgáljuk az elfogadott alkotmányokat, levonható az a következtetés, hogy a szervesebb történelmi fejlődéssel rendelkező országok alkotmányai stabilabbnak tekinthetőek, mivel ott ritkább az alkotmányozás. A „forradalmi alkotmányozással

\footnotetext{
${ }^{5}$ Például a Ciprusi Alkotmány 1. cikke szerint:,,A Ciprusi Állam független és szuverén prezidenciális köztársaság, amelynek elnöke görög, alelnöke török nemzetiségü, akiket Ciprus görög és török közösségei választanak a jelen Alkotmány szerint.", azonban nincs török alelnöke az országnak. http://www.presidency.gov.cy/presidency/presidency.nsf/DMLindex_en/DMLindex_en?OpenDocument ${ }^{6}$ DRINÓCZI TímEA: Az alkotmány legitimitásáról. Pázmány Law Working Papers, 2011/3. 2-4. pp.

7 Észak-Korea alkotmánya létezik, de az ország müködése nem alkotmányos a nyugati jogállami gondolkodás mércéjével. A másik „szélsőség” Nagy-Britannia, ahol nincs alkotmány, de az ország müködése alkotmányos. Az alkotmány és az alkotmányosság közti különbség a későbbiekben kerül vizsgálatra.

${ }^{8}$ A teljesség igénye nélkül: Mexikó alkotmánya - 1917, Weimari Alkotmány - 1919, Csehszlovákia alkotmánya - 1920 .
} 
rendszert váltó” országok - pl. Franciaország - és a „békésen rendszert váltó” országok - pl. Magyarország - alkotmányai gyakrabban változnak, nem övezi öket olyan tisztelet, mint azokat az alkotmányokat, amelyek akár évszázadok óta stabilan irányítják az adott ország működését, és „összeforrnak” a monarchiával. Ha megnézzük Norvégia (1814), Belgium (1830), Hollandia (1815), Luxemburg (1868), Dánia (1953) alkotmányait, mind régóta hatályban levők, vagyis a stabil társadalmi rendszer, a nyugodt politikai környezet elősegíti az alkotmány stabilitását. Ahol nem volt rendszerváltozás, forradalom, ott az alkotmány hosszú időn keresztül képes szerepét betölteni, tisztelete egyre nő. Ezekben az országokban értéknek is tekinthetjük az alkotmány stabilitását, hiszen kifejezi az egész társadalmi rendszer stabilitását. Ahol nincs társadalmi-politikai válság, megfelelően működnek az alkotmányos intézmények, ott maga az alkotmány szerepe is jelentősebb, mint azokban az országokban, ahol gyakran kerül sor új alkotmány elfogadására. Ezek az országok sok esetben monarchiák, kapcsolatot felételezhetünk a hosszabb távon hatályban levő alkotmányok és az államforma között, mivel a monarchiák tipikusan stabilabb politikai berendezkedéssel bírnak.

\subsubsection{A vizsgálat határvonalai és szempontjai}

A technikai fejlődés, az egyre gyorsabb információ-áramlás hatása megjelent az alkotmányjog mezsgyéjén is, hiszen az összehasonlító alkotmányjog segítségével megismerhetővé váltak az egyes országok alkotmányos megoldásai. ${ }^{9}$ A különböző nemzetközi standardok megkövetelésének egyre elterjedtebbé válása befolyásolja egy ország mozgásterét, amikor alkotmánymódosítás vagy új alkotmány elfogadása van napirenden. ${ }^{10}$

Az Európa Tanács égisze alatt a Velencei Bizottság vizsgálja az alkotmányosságot, a jogállami normák megjelenítését a tagállamok alkotmányaiban. A testület fó tevékenysége az ún. ,alkotmányos tanácsadás” (constitutional assistance), figyelemmel

\footnotetext{
9 Az összehasonlító alkotmányjog leggyakoribb alkalmazási módjai: „,külföldi példák felhasználása alkotmányozásnál -tág értelemben magában foglalja az alkotmányozást és az alktománymódosítást-és alkotmányértelmezésnél, valamint leirások és normativ értékelések kidolgozása során (...)”

The Oxford Handbook of Comparative Constitutional Law. (szerk.): ROSENFELD, MICHEL - SAJÓ ANDRÁS Oxford University Press, 2012. 6. p.

${ }^{10}$ Például egy izraeli összehasonlító alkotmányjogi anyag a Knesszet számára a Jövő generációkkal és a fenntartható fejlődéssel foglalkozó intézményekről: TESCHNER, NAAMA: Official Bodies that Deal With the Needs of Future Generations and Sustainable Development. Comparative Review 3. https://www.knesset.gov.il/mmm/data/pdf/me03194.pdf
} 
kísérni az Európa Tanács tagállami alkotmányainak minőségét, $\mathrm{s}$ így például az Alaptörvény elfogadásakor is több vizsgálatot lefolytatott. ${ }^{11}$ Emellett az EU normarendszere is meghatározó egy adott állam alkotmányainak kialakításakor a tagállamok esetében, hiszen az elvárt jogállami kritériumok rögzítettek. ${ }^{12}$

Latin-Amerikában az USA alkotmányos eszméi voltak jelentős hatással az alkotmányozásra, ${ }^{13}$ valamint a japán alkotmány kidolgozásakor is jelentős amerikai hatás érvényesült, akárcsak a volt szovjet befolyás alatt álló államokban a Szovjetunió alkotmányáé. Kérdéses, hogy abban az esetben miként lehet vizsgálni a stabilitást, ha az alkotmány nemzetközi szerződés részeként kerül elfogadásra, elég csak a Daytoni Békeszerződésre gondolni, amely több, mint húsz éve határozza meg egy ország müködését.

A vizsgálat tárgya tehát igencsak szerteágazó, azonban szétfeszítené e munka kereteit, ha globális szinten folytatnám a vizsgálódást, ezért az elemzés fókusza az Európai Unió tagállamainak alkotmányaira terjed ki, kiemelten kezelve a magyar alkotmányos rendszert. A különböző ázsiai, latin-amerikai és afrikai országok alkotmányos gyakorlata mutathat jó példát bizonyos alkotmányos kérdések megítélésekor, ${ }^{14}$ ám az eltérő kulturális, társadalmi berendezkedés miatt más következményekkel járhat ugyanolyan alkotmányos eszközök bevezetése, mint a mintaadó országban.

Az Európai Unió tagállamait vizsgálódási terepként meghatározva alakítható ki olyan keretrendszer, melyben a jogállamiság és az alkotmányos demokrácia követelményként megjelenik, egységet képezve az adott államok alkotmányos rendszerében. Ezek teremtik meg a megfelelő kiindulópontot a vizsgálódáshoz.

\footnotetext{
${ }^{11}$ Lásd: TRÓCSÁNYI LÁSZLÓ: Az alkotmányozás dilemmái Alkotmányos identitás és európai integráció. HVGOrac Lap- és Könyvkiadó, 2014. 110-124. pp.; CDL-AD(2011)001; CDL-AD(2011)016; CDL$\mathrm{AD}(2013) 012$

12 A koppenhágai kritériumok részletes listája meghatározza a csatlakozási feltételeket. https://ec.europa.eu/neighbourhood-enlargement/policy/conditions-membership/chapters-of-theacquis_en

A jogállamisági kritériumok pedig külön kérdést tesznek ki, lásd:

http://www.europarl.europa.eu/thinktank/en/document.html?reference=EPRS_IDA(2016)579328

${ }^{13}$ Például minden ország a prezidenciális kormányformát vette át alkotmányozása során. Lásd a latinamerikai alkotmányok stabilitásáról: NEGRETTO, GABRIEL L.: The Durability of Constitutions in Changing Envirnments: Explaining Cosntitutional Replacements in Latin America. The Helen Kellogg Institute for International Studies, Working Paper No. 350, August 2008. 11. p.

${ }^{14}$ Például az indiai Legfelső Bíróság alkotmányellenes alkotmánymódosításra vonatkozó gyakorlata jelentős hatással bírt számos ország alkotmányos gyakorlatára, lásd: ROZNAI, YANIV: Unconstitutional Constitutional Amendments The Limits of Amendment Power. Oxford Constitutional Theory, Oxford University Press, Oxford, 2017. 47-70. pp.
} 


\subsubsection{A magyar szempont}

Az Alaptörvény elfogadásának, valamint a jogrendszer jelentős változásainak hatására felélénkült a magyar alkotmányjogi szakirodalom. Néhány kérdés különösen nagy figyelmet kapott (történeti alkotmány vívmányai, ${ }^{15}$ alkotmányellenes alkotmánymódosítás), ${ }^{16}$ amelyeket érint az elemzés, de csak a stabilitás szemszögéből. Emellett a dolgozat inkább az összehasonlító nézőpontot helyezi előtérbe, nem a speciális magyar kérdéseket. ${ }^{17} \mathrm{Az}$ a hipotézis, hogy lehetséges egy ilyen garanciarendszert meghatározni egy demokratikus jogállamban. A cél tehát egy olyan garanciarendszer felállítása és bemutatása, amely bármely demokratikus országban támogathatja az alkotmány stabilitását, és az egyes elemek vizsgálatával elemezni lehet az alkotmány stabilitását.

\footnotetext{
${ }^{15} \mathrm{~A}$ teljesség igénye nélkül: ZLINSZKY JÁNOS: Történeti alkotmányunk fejlődése 1. rész és 2. rész. Magyar Szemle Új folyam XI. 3-4., 5-6. rész; SMUK PÉTER: Nemzetfogalom és történeti narratíva az Alaptörvényben. In: KECSKÉS GÁBOR (szerk.): Doktori Mühelytanulmányok, Széchenyi Egyetem Államés Jogtudományi Doktori Iskola, Győr, 2013, 286- 287. pp., CsINK LÓRÁNT - FRÖHLICH JOHANNA: Történeti alkotmány és kontinuitás az új Alaptörvényben. Közjogi Szemle 2012/1. 10-11. pp., SzENTE Zoltán: A historizáló alkotmányozás problémái - a történeti alkotmány és a Szent Korona az új Alaptörvényben. Közjogi Szemle, 2011/3. 1-13. pp; ORBÁn ENDRE: Az Alaptörvény paradoxonjai Átmenetböl? Átmenetbe! Közjogi Szemle, 2013/2. 51-58. pp.; MiLÁnKovich AndRÁs - SzentGáliTóTH BOLDIZSÁR: Diszitö elem vagy új értelmezési távlatok? A magyar közjog történeti dimenziói az Alaptörvény tükrében. Közjogi Szemle 2014/1. 65-74. pp; SZAKÁLY ZSUZSA: A történeti alkotmány és az alkotmányos identitás az Alaptörvény tükrében. Pro Publico Bono, 2015/2. 24-38. pp., 24-38. pp.; VÖRÖS IMRE: A történeti alkotmány az Alkotmánybiróság gyakorlatában. Jogtudományi Közlöny 2016/10. 491508. pp.; VARGA Zs. ANDRÁs: Történeti alkotmányunk vívmányai az Alaptörvény kógens rendelkezésében. Iustum Aeuum Salutare, 2016/4. 83-89. pp.

${ }^{16}$ Példák a külföldi szakirodalomból: ALBERT, RichARD: Nonconstitutional Amendments. Canadian Journal of Law and Jurisprudence, Vol. XXII., No. 1. January 2009, 5-47. pp.; BARAK, AHARON: Unconstitutional Constitutional Amendments. Isreal Law Review, 2011/44. 321-341. pp.; RozNAI 2017; ALBERT, RICHARD: The Theory and Doctrine of Unconstitutional Constitutional Amendment in Canada. Boston College Law School Faculty Papers 1-1-2016, 143-206. pp.; SAMAR, VinCENT J.: "Can a Constitutional Amendment Be Unconstitutional?" Oklahoma City Law Review Vol. 33 Iss. 3 (2009) 688748. pp.

Példák a magyar szakirodalomból: DRINÓCZI TíMEA: Újra az alkotmányozó, az alkotmánymódositó hatalomról és az alkotmányellenes alkotmánymódositásról - az Alaptörvény alapján - Jogtudományi Közlöny 2015/7-8, 361-378. pp.; GÁRDOS-OROSZ FrUZSINA: Az alkotmánymódositások alkotmányossági felülvizsgálata: elméleti koncepciók, nemzetközi trendek es magyar kérdések. in: GÁRDOS-OROSZ FRUZSINA - SZENTE ZOLTÁN (szerk.): Alkotmányozás és alkotmányjogi változások Európában és Magyarországon. Nemzeti Közszolgálati Egyetem Közigazgatás-tudományi Kar Budapest, 2014. 167184. pp.; KOCSIS MiKLós: Az Alkotmánybíróság határozata az „,alkotmányellenes alkotmánymódositások" ügyében Az indokolás koherenciahiányának következményei. Jogesetek Magyarázata 2011/3. 3-17. pp.; SZENTE ZOLTÁN: Az „alkotmányellenes alkotmánymódositás” és az alkotmánymódositások birósági felülvizsgálatának dogmatikai problémái a magyar alkotmányjogban. in: GÁRDOS-OROSZ FRUZSINA - SZENTE ZOLTÁN (szerk.): Alkotmányozás és alkotmányjogi változások Európában és Magyarországon, Nemzeti Közszolgálati Egyetem Közigazgatás-tudományi Kar Budapest, 2014. 209-241. pp.; ZSUGYÓ VIRÁG: Az Alkotmánybiróság határozata az alkotmánymódositások alkotmányossági felülvizsgálatáról Fogalmilag kizárt-e az alkotmányellenes alkotmánymódositás? Jogesetek Magyarázata Hallgatói különszám 2011. 52-62. pp.

${ }^{17}$ Az alkotmányozás összehasonlító vizsgálatáról lásd: ZsUGYÓ 2011. 132-146. pp.
} 
Természetesen foglalkozik az elemzés magyar szempontokkal, amennyiben talál hasonló példát folyamatra, módszerre, figyelembe véve minden esetben, hogy az alkotmányos transzplant nem alkalmazható alapos előkészítés és annak figyelembe vétele nélkül, hogy minden ország egyedi társadalmi, gazdasági, politikai körülményekkel rendelkezik, melyeknek hatására minden módszer, minta eltérő eredményekre vezet.

Az egyes garanciák elemzésénél azt vizsgálom, hogy erősítik-e az alkotmány stabilitását, majd a magyar rendszer áttekintése során azt feltételezem, hogy az egyes garanciák közül több is megjelenik a hatályos magyar szabályozásban. Ezek erősségének vizsgálata után javaslattal élek a jövőre nézve azzal a céllal, hogy erősödjön az alkotmány stabilitása.

A 2011-ben elfogadott magyar alkotmány több szempontból is fokozta az érdeklődést, hiszen komoly nemzetközi visszhangot váltottak ki bizonyos rendelkezései, ${ }^{18}$ és több kérdést is reflektorfénybe emelt, különös tekintettel arra, hogy Magyarország volt az első posztszovjet európai uniós tagállam, amely új alkotmány elfogadása mellett döntött az EU-csatlakozást követően. ${ }^{19}$ Számos vita merült fel a megoldások kapcsán.

Az eltérés adódhat abból is, hogy maga az alkotmány egy dokumentum - ez tekinthető tipikusnak, pl. a magyar alkotmány -, vagy több, különböző időpontban elfogadott, különálló törvényböl áll össze - pl. svéd alkotmány -. Alapulhat azon is, hogy az alkotmányozó akarat csak a legfontosabb kérdéseket tartotta szükségesnek a legmagasabb jogszabályi szinten szabályozni - pl. dán alkotmány -, vagy igyekezett a lehető legteljesebb körben rendezni az állami élet felmerülő kérdéseit - pl. portugál alkotmány -. Emellett számos egyéb szempont alapján is különbséget lehet tenni az alkotmányok között, azonban ez nem tartozik a kutatáshoz, hiszen annak célja az alkotmány stabilitásának vizsgálata. Álláspontom szerint ez egy alkotmány fontos tulajdonsága, hiszen az alkotmány az alkotmányos rendszer alapja, és ha maga a dokumentum instabil, könnyen azzá válhat a rajta alapuló szervezet- és garanciarendszer is.

Az alkotmány tartalma, megjelenési formája megváltoztatható egy döntéssel: új alkotmány elfogadásával vagy a meglevő alkotmány módosításával, azonban a stabilitás olyan jellemző, amelyre más módon hatnak ezek a döntések, hiszen maga a változtatás

${ }^{18}$ SZENTE Zoltán: Az Alaptörvény (2012-2015) in: Jakab András - Gajduschek György (szerk.): A magyar jogrendszer állapota MTA Társadalomtudományi Kutatóközpont, 2016. 222-227. pp.

${ }^{19}$ TRÓCSÁNYI 2014,17. p. 
ténye vagy annak elmaradása befolyásolja ezt a faktort, melynek segítségével magának az alkotmánynak a megfelelő alkalmazhatóságára, sőt, az adott állami berendezkedés stabilitására vonatkozóan is vonhatóak le következtetések.

$\mathrm{Az}$ alkotmány megváltoztatásához vagy új alkotmány elfogadásához mindenképp szükséges egy olyan politikai szándék, mely elindítja a folyamatot. ${ }^{20}$ Ezután a szükséges társadalmi támogatás kérdése merül fel, hiszen egy alkotmánynál kiemelt szerepe van a társadalmi legitimációnak, mert egy alkotmány stabilitását nagyban befolyásolhatja, hogy milyen a tisztelete a társadalom körében, amennyiben nincs magas társadalmi támogatottsága, az megnehezítheti beépülését a hagyományok közé.

\subsubsection{Módszertan}

A munka célja, hogy az általam meghatározott, az alkotmány stabilitását védő garanciákat vizsgálat alá vonva, azok jelentősége ebben a szerepkörükben megállapítható legyen. A kutatás során végig igyekeztem úgy használni a különböző módszereket, hogy ezt a szempontot segítsék elő, vagyis a szakirodalom feldolgozása során is azt tekintettem elsődlegesnek, hogy az ebbe az irányba előremutató, a rendszer kidolgozását elősegítő elméletek kerüljenek felhasználásra.

$\mathrm{Az}$ összehasonlító módszer használata kiemelt a dolgozatban, elsősorban külföldi alkotmányok szövegét használtam fel ahhoz, hogy például az alkotmány módosítására vagy új alkotmány elfogadására vonatkozó szabályokat megvizsgáljam.

A kapcsolódó szakirodalom feldolgozása során azt tapasztaltam, hogy rendkívül kiterjedt a kérdés vizsgálata, ezért mindig úgy szükítettem a felhasználást, hogy az adott részkérdéssel foglalkozó szerzők munkáit emeltem be az elemzésbe.

A kutatás során végig irányadónak tekintettem a Velencei Bizottság kérdésben elfogadott állásfoglalásait, véleményeit, hiszen a vizsgált EU-s országok mind tagjai az Európa Tanácsnak, vagyis a VB vizsgálatai kiterjednek rájuk, valamint a vélemények is kapcsolódnak.

A többi állam azért került ki a vizsgálódásból, mivel túl nagy a különbség az alkotmányos rendszerek, intézmények, értékek között. Milyen skála alapján döntsük el, hogy az adott állam megfelel-e a jogállamiság követelményeinek ${ }^{21}$

\footnotetext{
${ }^{20}$ TRÓCSÁNYI 2014, 41-42. pp.

${ }^{21}$ JAKAB ANDRÁs: A jogállamiság mérése indexek segitségével. Pázmány Law Working Papers, 2015/12. 1-21. pp.
} 
Az empirikus kutatás szempontjából hangsúlyos szerepet kaptak a magyar Alkotmánybíróság döntései, különös tekintettel a történeti alkotmány vívmányainak vizsgálatakor, hiszen ezt a speciálisan magyar fogalmat a testület kezdte el kidolgozni, a vonatkozó határozatok alapján vizsgálható, hogy milyen módszerekkel és mely intézmények esetében „fedezett fel” vívmányt az Alkotmánybíróság.

A történeti módszert csak kivételes esetekben, és visszafogottan kezeltem, mivel a téma tág értelmezési lehetőségeire és gazdag szakirodalmára tekintettel a jelenkori kérdések között is szürést kellett elvégeznem, ennek okán a történeti kérdések háttérbe szorultak. Kivételt képez ez alól a történeti bevezető rész, amely csak egy kis szelete a kérdést vizsgáló vonatkozó szakirodalomnak, azonban a dolgozat megalapozásához elengedhetetlennek tartottam ennek bevonását annak érdekében, hogy bemutassa, mi tekinthető modern kiindulópontnak a kérdés vizsgálata során.

Mivel az a cél, hogy a garanciák vizsgálata után a magyar alkotmányos rendszer vonatkozásában felhasználható tapasztalatok kerüljenek megállapításra, a komparatív módszer különösen hangsúlyosan jelenik meg több fejezetben is. Az alkotmány módosításával és az örökkévalósági klauzulákkal, valamint a preambulumokkal foglalkozó fejezetekben végig központi szereppel bír ez a módszer.

Az alkotmány stabilitásának fogalma szándékosan nincs meghatározva - a garanciákat vizsgálom, és azt az elméleti keretet, amely meghatározásukhoz szükséges, ami segít felrajzolni a keretet.

Az alkotmány stabilitását védő garanciák vizsgálata elött szükséges az elméleti alapok tisztázása. A gondolat alapjainak, valamint néhány releváns elméletnek az elemzése után a VB vonatkozó gyakorlatának rövid bemutatása következik, valamint elengedhetetlen az alkotmányozás és az alkotmánymódosítás egymáshoz való viszonyának elemzése is. A vizsgálat eredményeként kialakítottam egy szempontrendszert, amely bemutatja az alkotmány stabilitását védő garanciák rendszerét.

Kiindulópontként az alkotmányszövegekbe foglalt, az alkotmány módosítására, illetve új alkotmány elfogadására vonatkozó rendelkezéseket vizsgáltam az Európai Unió tagállamainak alkotmányszövegei alapján, melynek eredményeként felállítottam egy rendszert a módosítási eszközökre vonatkozóan, és megvizsgáltam, melyik ország milyen eszközöket használ, mennyire bonyolult az alkotmány módosítása, illetve az alkotmányozás. 
Ezt követően szintén a szöveg szintjén maradva vizsgáltam azokat az európai uniós tagállami alkotmányokat, melyek tartalmaznak explicit örökkévalósági klauzulákat. ${ }^{22}$ Az örökkévalósági klauzulákat tipizálva megállapítottam, hogy általában mely rendelkezések kapnak kiemelt védelmet az alkotmányozótól, megbontva az alkotmányos rendelkezések egységét.

Majd, ugyancsak az Európai Unió tagállamainak alkotmányaira kiterjesztve a vizsgálatot, a preambulumokat elemeztem abból a szempontból, hogy jelennek-e meg bennük a múltra és a jövőre utaló rendelkezések, mivel ezek segíthetik elő az összekötő kapocs erősítését a különböző generációk között az alkotmányban, melynek tisztelete esetén erősödhet a stabilitása is.

A jövőre utaló rendelkezések kapcsán érdemes vizsgálni a jövő generációk jogait is az alkotmány stabilitásának szemszögéből, hiszen általában egy alkotmány nem egy generáció számára íródik, ellentétben Jefferson véleményével, miszerint „,(...) minden alkotmány és minden jog természetes módon hatályon kívül helyezödik 19 év után. ", 23

A történeti lehetőségekre visszatérve érdemes vizsgálat alá vonni egy magyar „specialitást”, a történeti alkotmány vívmányait, mely új lehetőségeket biztosít az alkotmány értelmezése, valamint stabilitásának biztosítása során, az eddigi alkotmánybírósági gyakorlat rövid elemzése bemutatja a kérdés alapjait, valamint a benne rejlö lehetőségeket.

Az utolsó nagyobb fejezet az alkotmányellenes alkotmánymódosítások kérdését járja körbe. Bár első látásra úgy tünik, hogy ebben az esetben a vizsgálat elszakad az alkotmány szövegétöl, hiszen a bírói értelmezés területére kerül át a hangsúly, valójában azonban nem erről van szó, hiszen még mindig az alkotmány rendelkezéseinek - vagyis éppen az a kérdés, hogy a rendelkezéseinek-e - vizsgálata áll a bírói értelmezés középpontjában.

A vizsgált garanciák elemzésének eredményeit a Következtetések rész tartalmazza, melyben a magyar stabilitást erösítő jelenlegi garanciák vizsgálata után javaslatokat teszek arra, hogy miként lehetne erösíteni a magyar Alaptörvény stabilitását.

22 BRAgYOVA ANDRÁS - GÁRDOS-OROSZ FRUZSINA: Vannak-e megváltoztathatatlan normák az Alaptörvényben? Állam- és Jogtudomány, 2016/3. 50-53. pp.

23 The Founders' Constitution Volume 1, Chapter 2, Document 23, http://presspubs.uchicago.edu/founders/documents/v1ch2s23.html The University of Chicago Press;

The Papers of Thomas Jefferson. Edited by Julian P. Boyd et al. Princeton: Princeton University Press, $1950-$ 


\subsection{Az alkotmány stabilitásáról}

\subsubsection{Miért nem alkotmányos stabilitás?}

Az első kérdés az alkotmányos stabilitás és az alkotmány stabilitása közti különbség. Az alkotmány stabilitása azt fejezi ki, hogy magáról a konkrét dokumentumról van szó, míg az alkotmányos stabilitás kifejezés ennél messzebbre mutat. Az alkotmányosság fogalma ugyanis túllép a szöveg szintjén, és elvi szinten mutat rá a legfontosabb jellemzőkre, melyek szükségesek egy ország alkotmányos működéséhez. A jogállamisággal állítható párhuzamba abból a szempontból egyes álláspontok szerint, hogy „,...) az egész közélet értékelvü szabályozását, a közrend és a közéleti tisztaság biztositását szolgálja, ,, ${ }^{24}$ de nem szinonim fogalmak, viszont a ,,(...) a jogállam elvei, követelményei, intézményei elösegitik az alkotmány alapvető tételeinek érvényesülését.". ${ }^{25}$ Tehát szoros kapcsolat van a két fogalom között, azonban ennek a kapcsolatnak a részletes vizsgálata szétfeszítené e munka szándékozott kereteit. Ezért nem az alkotmányos stabilitás kifejezés szerepel a címben.

Arra azonban szükséges felhívni a figyelmet, hogy „,...) egyik fogalomnak sincs vitán felül álló definíciója, így a közöttük lévő viszonyt illető állásfoglalások is lényegüknél fogva vitathatóak maradnak, mivel a jogállamiság egy meghatározott koncepcióját csak az alkotmányosság egy meghatározott koncepciójával vethetjük össze értelmesen. „26 Vagyis csak bizonyos esetekben vizsgálható ez a kapcsolat. ${ }^{27}$

A szövegszint jelentősége néha háttérbe szorul a többihez képest, azonban jelentős szerepe lehet magának a szövegnek is - természetesen nem minden esetben -, mivel a formális alkotmányt ez határozza meg. Alapelvnek tekinthető, hogy „Nem minden, ami alkotmányos van leírva, és nem minden, amit leírtak, alkotmányos. ", ${ }^{28}$ vagyis nem mindig garanciája a szövegszint megfelelösége egy állam alkotmányos müködésének.

Az alkotmány tehát csak akkor alkotmányos, ha megfelel a jogállamiság követelményeinek. Felvetődik, hogy ebben az esetben, ha létezik egy demokratikus alkotmány, az milyen módon tudja követni a társadalmi, gazdasági, politikai

\footnotetext{
${ }^{24}$ SAMU MiHÁLY: Alkotmányozás, alkotmány, alkotmányosság Korona Kiadó, 1997. 130. p.

${ }^{25}$ SAMU 1997, 130. p.

${ }^{26}$ GYÖRFI TAMÁS - JAKAB ANDRÁS: $2 . \oint$ [Alkotmányos alapelvek; ellenállási jog] In: JAKAB ANDRÁS (szerk.): Az Alkotmány kommentárja, I., Századvég Kiadó, Budapest, 2009. [239]

${ }^{27}$ GYÖRFI - JAKAB 2009, [240-242]

${ }^{28}$ Blount, Justin - Elkins, ZACHARY - GinsbURG, TOM: Does the Process of Constitution-making Matter? in: TOM GinSBURG, (szerk.): Comparative Constitutional Design, University of Chicago, School of Law, Cambridge University Press, 2012. 36. p.
} 
változásokat, azaz mennyire rugalmas vagy merev. Fontos kérdés, hogy az alkotmány stabilitása miként befolyásolja egy ország alkotmányosságát, hiszen egy könnyen módosítható alkotmány elősegítheti a változásokhoz való gyors alkalmazkodást, ugyanakkor veszélyeztetheti a jogbiztonságot. ${ }^{29}$ Más szempontot vizsgálva, egy túlzottan merev alkotmány gátja lehet a fejlődésnek, bár biztosítja az alkotmány alapjainak védelmét, de amikor a változás szükséges lenne, nem biztos, hogy sikerül megváltoztatni, ha túl bonyolultak a szabályok, melyekkel módosítani lehet az alkotmányt, vagy újat elfogadni.

Természetesen nem vitatom az alkotmányba foglalt értékek jelentőségét, ${ }^{30}$ azonban nem értékközpontú elemzést végzek, hanem szövegközpontút.

$\mathrm{Az}$ értékközpontú elemzések jelentősége nem vitatható, hiszen „,[m]aradéktalanul objektív alkotmány, alkotmányos- rend és jogrend legfeljebb elméleti konstrukcióként létezhet (...), "31 vagyis minden alkotmány tartalmaz szükségképpeni értékválasztásokat, nem lehet teljes mértékben semleges, azonban az értékválasztás és következményei vizsgálata más irányt adna a munkának, ezért a szövegszint vizsgálata marad az elsődleges.

Ádám Antal szerint „,(...) a vázolt alkotmányi értékeket tiszteletben tartó társadalmi, politikai és állami rendszer az értékteremtés, értékrendezés és értékvédelem állandó folyamata. Mindehhez mellözhetetlen, hogy az alkotmány minél korszerübb és gazdagabb tartalommal, minél világosabban határozza meg az alkotmányi értékek jelzett csoportjainak összetevöit. "32

Az alkotmánynak értékkatalógusként is kell funkcionálnia, amely elösegíti az alkotmányos értékek érvényesülését, azonban az értéktartalmú vizsgálat az alkotmányosság témájához tartozik, ezért ilyen szempontú elemzést a dolgozatban csak itt végzünk röviden, valamint a preambulumok múltra és jövőre utaló rendelkezéseinek elemzésénél, mivel abban az esetben nem lehet eltekinteni az értéktartalmú vizsgálattól. A vállalt önkorlátozással nagyjából külön lehet kezelni a textualista és az értékközpontú elemzést, az utóbbi szintén összetett kérdés, egy későbbi külön munka tárgya lehet vizsgálni az alkotmányok stabilitásának mélyebb alapjait, ugyanis a társadalmi,

\footnotetext{
${ }^{29}$ CDL-AD (2010)001

30 Hiszen az alkotmány értelmezésekor „Az értelmező az alkotmány írott szövegéböl indul ki, és racionális érveléssel juthat el a következetetésig." То́TH GÁBOR ATTILA: Túl a szövegen Értekezés a magyar alkotmányról Osiris, 2009. 108. p.

${ }^{31}$ VARGA ZS. ANDRÁS: Alkotmányunk értékei. Fogalmi keretek. Iustum Aequum Salutare, 2009/1, 97. p.

32 ÁDÁm ANTAL: Az alkotmányi értékek fejlödési irányairól. Jura 2002/1, 20. p.
} 
kulturális, politikai, gazdasági környezet nagyban befolyásolja a garanciák gyakorlatban való érvényesülését.

\subsubsection{Miért nem alkotmányosság?}

Az elemzés során a szövegközpontú metódust választottam, amelynél a tételes alkotmányszövegeket tekintettem kiindulópontnak, nem pedig az alkotmány mögöttes értékeit, vagy a kialakult alkotmánybírósági/felsőbírósági gyakorlatot, netán az alkotmányos szokást vagy kultúrát. Természetesen a szöveg vizsgálatához elengedhetetlen a vonatkozó szakirodalom, elméleti háttér megismerése és bemutatása. Az alkotmányosság fogalmának vizsgálatát mellőzve a stabilitással foglalkozom, hiszen az alkotmányosság fogalmának alapos elemzéséhez szükséges a szociális, gazdasági, politikai és kulturális kérdések vizsgálata is, ${ }^{33}$ amelyek szétfeszítenék az elemzést. Az alkotmányosság kérdéséhez hozzátartozik a társadalmi véleménynyilvánítás vizsgálata is, amely meghaladná a szövegközpontú elemzést a kialakult elméletek vizsgálatba vonásával. Azonban az alkotmányosság fogalmának rövid elemzése szükséges ahhoz, hogy megfelelő keretrendszeren belül folyhasson az alkotmány stabilitását védő garanciák vizsgálata.

Ha a hazai szerzők véleménye alapján vizsgáljuk meg a teljesség igénye nélkül az alkotmányosság fogalmát, az alábbi álláspontokat találhatjuk:

Takács Imre szerint „Az alkotmányosság olyan elvi követelmények együttese, amelyek az ideális demokratikus alkotmány tartalmát és megvalósulását jellemzik."34 Antal Attila elhatárolja a jogi és politikai alkotmányosság fogalmát, így elemezve a magyar helyzetet. ${ }^{35}$ Véleménye szerint 1989-től 2010-ig a jogi alkotmányosság volt domináns, azonban 2010 óta a politikai alkotmányosság vált uralkodóvá, ${ }^{36}$ amely jelentős mértékben befolyásolta az egész alkotmányos rendszer müködését. A jogi alkotmányosság jellemzője, hogy az alapjogok biztosítását, azok bírói felülvizsgálatot emeli a középpontba, míg a politikai alkotmányosság eszméje szerint a többségi elv érvényesülésével a demokrácia procedurális védelme áll a fókuszban. ${ }^{37}$ Álláspontja

\footnotetext{
${ }^{33}$ SAMU 1997, 127. p.

34 TAKÁCS IMRE: Az alkotmány és az alkotmányosság fogalma. in: Kukorelli István (szerk.): Alkotmánytan I., Alapfogalmak, alkotmányos intézmények 2., átdolgozott kiadás, Osiris Kiadó, Budapest, 2007. 29. p.

35 AnTAl ATTILA: Politikai és jogi alkotmányosság Magyarországon. Politikatudományi Szemle XXII/3. 50-64. pp.

${ }^{36}$ ANTAL 2013, 57. p

${ }^{37}$ ANTAL 2013, 50-53. pp.
} 
szerint azért került az Alkotmánybíróság a viták középpontjába, mert a jogi alkotmányosság eszmerendszerében az alkotmánybíróság szerepe meghatározó, ezért a politikai alkotmányosság egyik első feladata volt ezen változtatni. ${ }^{38}$

Kovács Ágnes a politikai konstituticionalizmus elméletével kapcsolatban rámutat arra, hogy a politikai hatalom ebben a modellben sem lehet korlátok nélküli, mivel explicit uniós és alapjogi korlátok, valamint a bírói jogvédelem is része a rendszernek. ${ }^{39}$ Álláspontja szerint kötik ebben az esetben is bizonyos korlátok a politikai döntéshozót, míg Antal álláspontja szerint ebben az esetben a „a jog a politika "szolgálóleánya«”. ${ }^{0}$ Petrétei József alapos elemzését adja a fogalomnak, felhívja a figyelmet arra, hogy az alkotmányosság egyszerre követelmény és állapot. ${ }^{41}$ A következő feltételeket állapítja meg az alkotmányosság érvényesüléséhez:

- korszerü szabályozási tartalommal rendelkező, stabil alkotmány,

- az alkotmányos rendelkezések érvényesülésének megfelelő biztosítékai,

- alkotmányos ellenőrzés rendszere,

- keletkezett alkotmánysértések orvoslása. ${ }^{42}$

A stabilitással kapcsolatban így fogalmaz: „A stabilitás követelménye azt jelenti, hogy az alkotmány elöirásainak elvben tartósan, hosszabb idöre szólóan, és a jövöre vonatkozóan kell megtervezniük és kialakitaniuk a társadalmi együttélés számára szükséges alaprendet. ", ${ }^{43}$ vagyis az alkotmányosság egyik feltételének tartja azt, hogy hosszabb távon érvényesüljön az alkotmány, stabilan biztosítsa a rendszer alapjait."44 Az alkotmány stabilitása az alkalmazhatóság kritériuma inkább, de ez is beleértendő az abszolút alkotmányosságba, hiszen lehet egy alkotmány stabil, de ha nem tartják be a benne foglaltakat, ha nincs kötőereje, ha nem érvényesülnek egyes elemei. Hiába van egy jól müködő rendszer az alkotmányba foglalva, ha az csak leírás („használati útmutató”) marad.

Az alkotmány szövegének stabilitását vizsgálva fontos kiemelni, hogy a szöveg tartalma változatlan formaiság mellett is megújulhat, ahogy az az USA példájából is látható, azonban az alkotmány szövegének kiszámíthatósága egy olyan érték, mely segítséget

\footnotetext{
38 ANTAL 2013, 63. p.

39 KovÁCs ÁGNES: Fényevők? A hazai alkotmányelmélet esete a politikai konstitucionalizmussal. Fundamentum 2015/2-3. szám. 20. p.

${ }^{40}$ ANTAL 2013, 60. p.

${ }^{41}$ Petrétei JózSEF: Az alkotmányos demokrácia alapintézményei. Dialóg Campus, 2011, 100. p.

42 PeTRÉTEI 2011, 99-115. pp.

43 PeTRÉTEI 2011, 102. p.
} 
nyújthat az állampolgároknak fogódzót találni a változások során, mivel értékhordozóként jelenik meg a szemükben. Hiszen egy alkotmány szövege - normál körülmények között - nem változik olyan gyakran, mint egy rendes törvényé. Az állampolgároknak rendelkezésére áll kellő idő arra, hogy elkezdjenek kötődni a szöveghez, tiszteljék azt, főleg, ha érvényesül is, betartják és betartatják az alkotmányba foglaltakat.

\subsubsection{Miért nem jogállamiság?}

A témához szorosan kötődik a jogállamiság kérdése, ugyanis az alkotmány stabilitását védő garanciák vizsgálatának az alkotmányosság mellett a jogállamiság adja meg a háttérben húzódó keretét, ugyanis a jogbiztonság fogalmához hozzátartozik az is, hogy stabil legyen az alkotmány, hiszen az egész jogrendszer stabilitására kihatással van az alkotmány stabilitása, és ha instabil az alkotmány, az a jogbiztonságra is hatással lesz.

Egy megfelelően müködő alkotmányos rendszer elképzelhetetlen a jogállami elvek érvényesülés nélkül. A jogállamiság komplex fogalmának alapos vizsgálata ${ }^{45}$ más irányba vinné az elemzést, azonban azt fontosnak tartom leszögezni, hogy az elemzés során végig a jogállamiság kereteit tekintem alapvetőnek abból a szempontból, hogy egy alkotmányos állam müködéséhez elengedhetetlen a jogállamiság biztosítása.

Varga Zs. András a jogállam fogalmával kapcsolatban arra a következtetésre jut, hogy az Alkotmánybíróság számára „szabad kártyaként” minden kérdésben felhasználható eszközként szolgál, ${ }^{46}$ „egyfajta varázspálca szerepet kapott” ${ }^{47}$ Úgy véli, hogy az Alaptörvény hatályba lépése után az Alkotmánybíróság lassan ,,szakitott az önkényes, a jogállamiságot csak a jogállamisághoz mérö értelmezési kerettel, és elfogadja az alkotmányozó hatalom primátusát. "48 Nem ért egyet az alapjogi fundamentalistákkal ${ }^{49}$ Varga Zs., amely elmélet szürő nélküli alkalmazása valóban túlzó lehet, azonban az alkotmányozó annyi irányból megkötötte az Alkotmánybíróság kezét, ${ }^{50}$ hogy nem állt fenn a bírói túlhatalom veszélye álláspontom szerint.

\footnotetext{
${ }^{45}$ A fogalom részletes elemzését lásd például: 2009. = GYÖRFI - JAKAB 2009, [73]-[284]; ÁDÁM ANTAL: Bölcseletek, vallások, jogi alapértékek. Pécs, 2015, 387-402. pp.; PETRÉTEI 2011, 139-159. pp.; VARGA Zs. ANDRÁS: Eszményből bálvány? A joguralom dogmatikája. Századvég Kiadó, 2015, 87-108. pp.

${ }^{46}$ VARGA Zs. 2015, 16-18. pp.

47 VARGA Zs. 2015, 169. p.

${ }^{48}$ VARGA Zs. 2015, 136. p.

${ }^{49}$ ANTAL 2013 54-55. pp.

${ }^{50}$ ANTAL 2013, 63. p.
} 
Azért alakult ki ez a szerepe a jogállamiságnak, mert amikor az Alkotmánybíróság szükségét érezte, hogy az adott kérdésben döntést hozzon, de ehhez kiterjesztő értelmezésre volt szükség, akkor a jogállamiság elve tudott segíteni. Ha a testület a megfelelő alkalmakkor él a használatával, álláspontom szerint egy ilyen szabad kártya hasznos, mivel segítő kezet nyújt abban az esetben, amikor az alkotmány rendelkezései nem kellően egyértelmủek egy kérdés megítéléséhez, azonban a túlzott alkalmazással szemben önmérsékletet kell tanúsítani használójának.

A jogállamiság definíciójának bizonytalanságára hívja fel a figyelmet Trócsányi László. ${ }^{51}$ Mivel a fogalom meghatározása kontextusfüggő, az alkotmány szövegének több értelme is lehet ebben a kérdésben, amelynek részletes vizsgálata értékközpontú elemzéshez vezetne. Az azonban megállapítható, hogy a jogállamiság fogalma kiemelkedő jelentőséggel bír, ezért óvatos használata ajánlatos annak érdekében, nehogy parttalanná váljon.

\subsubsection{Jogszociológiai szempont}

Mellőzöm a jogszociológiai szempontokat, noha a társadalmi jogtudat megléte - vagy annak hiánya - nagyban befolyásolja az alkotmány elfogadottságát. Ha az állampolgárok tisztában vannak például alkotmányos jogaikkal, és azokra hivatkoznak is a mindennapokban, vagy a többség ismeri az alkotmányba foglalt rendelkezéseket, akkor jobban magukénak érzik a szöveg változásait is. Nagyobb érdeklődés övezi az alkotmányozást/alkotmánymódosítást, mivel jobban kötődnek a szöveghez, ezáltal fontosabb annak változása is, mert közvetlenebb a kapcsolat.

Nem az alkotmány stabilitásának védelmét szolgáló konkrét gyakorlatokat elemzem, hanem olyan jogi konstrukciókat, amelyekkel biztosítani lehet a stabilitást, nem pedig a tényleges eseteket, a garanciák használatának valós eredményei külön kérdést képeznek. A másik szempont a szokásjog és az alkotmány kapcsolata. Amennyiben az adott ország alkotmányába foglalt bizonyos rendelkezéshez képest lex imperfecta alakult ki a gyakorlatban akár a jogalkalmazók, akár a társadalom cselekményei révén, akkor az eredeti alkotmányos rendelkezés a múlt homályába veszhet, és a bevált szokás él a

51 TrÓCsÁNYI LÁszló: Tagság, jogállamiság, Európai Unió. in: JAKÓ MIRA ANNA (szerk.): Nemzeti identitás és alkotmányos identitás az Európai Unió és a tagállamok viszonylatában, Generál Nyomda Kft, Szeged, 2014, 10-12. pp. 
társadalmi gyakorlatban. Ha elég nagy ennek a társadalmi támogatottsága, az ahhoz is vezethet, hogy ennek hatására megváltoztatják magát a jogszabályt is.

Az alkotmányok formális és társadalmi elfogadottságát nem választja szét Szentpéteri István, akinek álláspontja szerint „Az alkotmány társadalmi elfogadottsága végeredményben azon nyugszik, hogy maga a jog mennyire és milyen minöségben „elfogadott” (érvényesül) az adott társadalomban." 52 Ez abból a szempontból logikus, hogy valóban az alkotmányon alapul az egész jogrendszer, tehát ha az egyes részeket elfogadja a társadalom, akkor az egészet is.

\subsubsection{Az Európai Unió joga és a nemzetközi jog?}

Az Európai Unió joga és a nemzetközi jog korlátozza az egyes államok szuverenitását, vagyis nemcsak az alkotmánymódosító, hanem az alkotmányozó hatalomnak is tekintettel kell lennie ezekre a limitációkra.

A belső jog, az európai uniós jog, valamint a nemzetközi jog kapcsolata olyan komplex rendszer, hogy egy-egy részkérdésének elemzése is külön kutatás tárgya. ${ }^{53} \mathrm{~A}$ stabilitási eszközök vizsgálatánál ebbe a keretbe helyeztem bele az alkotmányok vonatkozó részeit és magukat a garanciákat, hiszen napjainkban nem érvényesülhet egyetlen alkotmány sem légüres térben. Tekintettel kell lenni a belső társadalmi elfogadottság mellett a nemzetközi, európai szabályokra és közvéleményre is. A magyar Alaptörvény elfogadása körüli nagy nemzetközi érdeklődés is ezt példázza. ${ }^{54}$

\subsubsection{Az alkotmány stabilitásának szerepe}

Mivel az alkotmányok szövege tipikusan absztrakt, az adott körülményekre való alkalmazása során ritkábban alakul ki az a szituáció, hogy elavul a szöveg, és szükségessé válik annak korrigálása, netán egészen új alkotmány elfogadása, mint a rendes törvények esetében. Ennek nyilvánvaló pozitív értéktartalma mellett olyan

\footnotetext{
${ }^{52}$ SZENTPÉTERI ISTVÁN: Az alkotmány társadalmi legitimitása. In: KovÁCS ISTVÁN (szerk.): Alkotmány és alkotmányosság, Akadémiai Kiadó, Budapest, 1989, 48. p.

${ }^{53}$ BLUTMAN LÁsZLó: A magyar Lisszabon-határozat: befejezetlen szimfónia luxemburgi hangnemben. Alkotmánybírósági Szemle, 2010/2. 90-99. pp.; BLUTMAN LÁszLÓ: Szürkületi zóna: az Alaptörvény és az uniós jog viszonya. Közjogi Szemle, 2017/1. 1-14. pp.; CHRONOWSKI NÓRA: „Integrálódó" alkotmányjog. Dialóg Campus Kiadó, 2005. 93-116. pp., 248-265. pp CHRONOWSKI NÓRA - VINCZE ATTILA: Önazonosság és európai integráció - az Alkotmánybiróság az identitáskeresés útján. Jogtudományi Közlöny 2017/3. 117-132. pp.; VÖRÖS IMRE: Csoportkép Laokoónnal A magyar jog és az alkotmánybiráskodás vívódása az európai joggal., HVGOrac Lap- és Könyvkiadó Kft., 2012. 17-31. pp.; JAKAB ANDRÁs: Az európai alkotmányjog nyelve, NKE Szolgáltató Nonprofit Kft., 2016. 109-120. pp.

${ }^{54}$ TRÓCSÁNYI 2014, 97-128. pp.
} 
következményei is lehetnek, amelyek negatív hatással bírhatnak. Ha avíttá válnak az alkalmazandó alkotmányos rendelkezések, kisebb változtatás szükségessége esetén alkotmánymódosítással, teljes revízió esetén alkotmányozással lehet kiküszöbölni a problémát, egyfajta alkotmányos „,evolúció” keretében. Ennek hatására az alkotmányos rendszer lépést tud tartani a korral, képes megfelelő keretrendszert biztosítani az adott állam müködéséhez.

Egy adott ország alkotmányának stabilitása legalapvetőbben abban nyilvánul meg, hogy milyen gyakran változik maga az alkotmány szövege, milyen idöközönként érzi szükségét az alkotmányozó/alkotmánymódosító a változtatásnak, vagyis a gyakorlati tapasztalatok alapján milyen időközönként sikerül a változtatáshoz szükséges feltételeket teljesíteni az alkotmányozónak/alkotmánymódosítónak. Ez a kiindulópont, ám az ún. informális alkotmánymódosító módszerek vizsgálatától sem lehet eltekinteni a teljes kép megrajzolásához. Bizonyos országok alkotmányos gyakorlata ezeken alapul, ${ }^{55}$ nélkülük nem lehet megfelelő értelmezési keretet kialakítani. ${ }^{56}$ Informális például a kötőerővel rendelkező bírói értelmezés, az alkotmányos szokás, az alkotmányos kultúra, ${ }^{57}$ vagy az alkotmányos akadályok feltételezése.

Az alkotmány stabilitásának jelentőségét egyre többen felismerik, hiszen „A stabilitás kétség kívül alapvető feltétele az alkotmány alapján álló jogrendszereknek; (...)”,,58 az alkotmány módosítása pedig ezt a kérdést érinti. Egyes szerzők szerint „az alkotmányok módositásánál a fö pont az, hogy a módositásból következhet-e a létezö alkotmány jogi lerontása." ${ }^{59}$ Vagyis minden esetben figyelni kell a módosítás következményeire, hiszen lehet, hogy ritkán változtatják meg az alkotmányt, de ha ennek a módosításnak a tartalma káros hatással van a szövegre, máris veszélybe kerülhet az alkotmányosság.

Előkérdésként a merev és rugalmas alkotmányok kérdését célszerü megvizsgálni, hiszen ez a distinkció segítheti a stabilitás kérdésének megértését.

\footnotetext{
${ }^{55}$ Egyes szerzők szerint nincs jelentősége a formális alkotmánymódosításoknak az informálisok mellett, lásd: STRAUSS, DAVID A.: The Irrelevance of Constitutional Amendments. Harvard Law Review, Vol. 114, 2001. 1469-1478. pp.

${ }^{56}$ CDL-AD(2010)001 22-24. pp.

${ }^{57}$ CDL-AD(2010)001 22-24. pp.

58 CSINK LÓRÁNT - FRÖHLICH JOHANNA: A Haining-elv Az alkotmány identitása, stabilitása és változtathatósága. Iustum Aequum Salutare 2016/4. 22. p.

${ }^{59}$ NEGRETTO 2008, 2. p.
} 
Az alkotmánynak kiemelkedő szerepe van az adott állam müködésében, beleértve „néhányat a legalapvetőbb társadalmi játékszabályok közül”, ${ }^{60}$ Egy demokratikus ország müködése az alkotmányába foglalt elveken alapul, ennek okán „a lehető legszélesebb körü demokratikus legitimációt igényli, ami csak elképzelhető", ${ }^{61} \mathrm{Az}$ alkotmány speciális helyzete okán érthető, hogy elfogadásának és módosításának szabályai is különlegesek, mivel néha a társadalmi alapok frissítése is szükséges. ${ }^{62}$

Egy új alkotmány elfogadása vagy az alkotmány módosítása mindig jelentős esemény, mivel komoly hatása lehet az állam és a társadalom müködésére. „Továbbá, a módositási eljárások hozzájárulhatnak az alkotmányos berendezkedés stabilitásának és tartósságának megerösitéséhez, ennek okán hatással lehetnek a közjóra, hogyha olyan elemeit, mint a konjunktúra, az egészség és a bizalom stabil közrendi intézmények védik. "63

\subsubsection{Merevés rugalmas alkotmányok}

Az alkotmányok összehasonlító vizsgálata során tipikus, mondhatni tankönyvi elhatárolási szempont az adott alkotmány merevsége, illetve rugalmassága ${ }^{64} \mathrm{Ez}$ a kérdés az alkotmánynak arra a tulajdonságára reflektál, hogy milyen nehéz megváltoztatni. Alapvetően az alkotmány módosítására és új alkotmány elfogadására vonatkozó jogszabályi rendelkezések határozzák meg ezt a kérdést, azonban ezek hatása az alkotmány rugalmasságára önmagában nem ad választ. Példának okáért az adott alkotmányt értelmező bírói testület értelmezési gyakorlata képes helyettesíteni a szükséges módosítást - mint pl. az USA-ban -, vagy bár a többi államhoz képest nem tünik nehéznek a változtatáshoz szükséges szabályok megfelelö alkalmazása, mégis az adott ország valós politikai állapota szinte megvalósíthatatlanná teszi a szükséges változtatást. Mivel Magyarországon a megválasztott országgyűlési képviselők szavazatának kétharmada szükséges az alkotmány módosításához vagy új alkotmány elfogadásához, ez alapján európai viszonylatban igencsak rugalmasnak tekinthető. Ám a politikai pártok közötti megegyezés hiányában - adott esetben - évekig sikertelen

\footnotetext{
${ }^{60}$ RASCH, BJORn ERIK- CONGLeton, Roger D.: Amendment Procedures and Constitutional Stability. in. Roger D. Congleton \& BirgitTa Swedenborg (szerk.): Democratic Constitutional Design and Public Policy. Analysis and Evidence. MIT Press, 2006, 538. p.

${ }^{61}$ ELKINS - GINSBURG -MELTON 2009, 36. p.

${ }^{62}$ A változás lehetséges okai: LuTz 1995a, 242. p.

${ }^{63}$ RASCH - CONGLETON 2006, 537. p.

${ }^{64}$ Például: TRÓCSÁNYI LÁSZLÓ - SCHANDA BALÁZS: Bevezetés az alkotmányjogba. HVGOrac Lap- és Könyvkiadó, 2015, 33-35. pp.
} 
maradhat az alkotmány szükséges módosítása. Példa erre a kormányhivatalok helyi önkormányzati rendeletek feletti törvényességi ellenőrzési hatáskörének bevezetése. ${ }^{65}$ Akadnak olyan jellegü alkotmánymódosítási, illetve elfogadási szabályok, melyek valóban megnehezítik a változtatást. Az USA alkotmányának megváltoztatásához az szükséges, hogy a Kongresszus mindkét háza elfogadja kétharmados többséggel a módosítást és a tagállamok háromnegyede azt elfogadja; vagy nemzetgyülést hívnak össze a tagállamok kérésére, ahol szintén a tagállamok háromnegyedének támogatása szükséges az új rendelkezések elfogadásához. ${ }^{66}$ Nem egyszerű ezeken az utakon elérni az alkotmány megváltoztatásához a támogatást. Az USA Legfelső Bírósága talált módot arra, hogy alkotmányértelmezésével lehetővé tegye az 1787-es szabályok alkalmazását napjainkban is. ${ }^{67}$ Azonban az alkotmány módosításához szükséges parlamenti többség vizsgálatakor mindig tekintettel szükséges lenni arra, hogy nagyban befolyásolja a választási rendszer és a pártszerkezet annak realitását, hogy miként lehet elérni a szükséges többséget a képviselők között.

Hasonló példával szolgálhat Belgium, ahol szintén bonyolult eljárás eredményeként lehetséges módosítani az alkotmányt vagy új alkotmányt elfogadni, ${ }^{68}$ noha itt volt már

65 90/2007. (XI. 14.) AB határozat

${ }^{66}$ Article V. ,The Congress, whenever two thirds of both Houses shall deem it necessary, shall propose Amendments to this Constitution, or, on the Application of the Legislatures of two thirds of the several States, shall call a Convention for proposing Amendments, which, in either Case, shall be valid to all Intents and Purposes, as Part of this Constitution, when ratified by the Legislatures of threefourths of the several States, or by Conventions in threefourths thereof, as the one or the other Mode of Ratification may be proposed by the Congress; Provided that no Amendment which may be made prior to the Year One thousand eight hundred and eight shall in any Manner affect the first and fourth Clauses in the Ninth Section of the first Article; and that no State, without its Consent, shall be deprived of its equal Suffrage in the Senate."

http://www.senate.gov/civics/constitution_item/constitution.htm

${ }^{67}$ Mint például a privacy vagy az azonos nemüek házasságkötése esetében.

${ }^{68}$ Belgium Alkotmánya VIII. cím Az Alkotmány felülvizsgálata

„195. cikk. A törvényhozó hatalomnak jogában áll kijelenteni, hogy bizonyos, az általa megjelölt alkotmányos rendelkezés felülvizsgálata szükséges.

Ilyen kijelentés után a két kamara jogszabály erejénél fogva feloszlik.

A 46. cikk szerint két új kamara összehívására kerül sor.

Ez a két kamara a királlyal egyetértésben dönt a felülvizsgálat alá vett kérdésekröl.

Ebben az esetben a kamarák csak akkor tanácskozhatnak, ha a mindkettöt alkotó tagoknak legalább kétharmada jelen van és egyetlen módositásra sem kerülhet sor, ha nem szerzi meg a legalább kétharmados szavazattöbbséget.

196. cikk. Az Alkotmány semmilyen felülvizsgálata sem nem kezdeményezhetö, sem nem folytatható le háború idején, vagy ha a kamarák akadályozva vannak abban, hogy a szövetségi területen szabadon ülésezzenek.

197. cikk. Az uralkodó kiskorúsága vagy távolléte (a régenség) idején semmilyen változtatás sem tehetö az Alkotmányban a király alkotmányos jogositványait illetően és az Alkotmány 85-88., 91-95., $106-197$. cikkeiben.

A királlyal való egyetértésben az alkotmányozó kamarák rendezhetik az Alkotmány cikkeinek, valamint az egyes cikkek felosztásainak számozását, és az Alkotmány címekre, fejezetekre és részekre osztását, 
példa módosításra. ${ }^{69}$ Nem egyszerű végig vinni egy olyan folyamatot az alkotmányozó számára, amelynek része, hogy a parlament házait feloszlatják és új választásokat írnak ki.

Annak ellenére, hogy ezekben az országokban kifejezetten bonyolultnak tünhet az alkotmány módosítása, illetve új alkotmány elfogadása, a véghezvitelükhöz szükséges széles körü társadalmi összefogás azt jelzi, hogy olyan okból kerül sor a változtatásra, amely valóban komoly támogatottságot élvez a választópolgárok körében. Emellett léteznek egyéb utak is az alkotmány jelentésének módosítására, ha maga a szöveg nem is változik. $^{70}$

A túlzott merevség mellett a túlzott rugalmasság sem feltétlenül üdvözítő megoldás, ugyanis az alkotmány túl gyakori változtatása könnyen ingataggá teheti a tiszteletet magával a dokumentum tartalmával szemben is, melynek hatására akár a jogállamiság tisztelete is csökkenhet az adott államban. ${ }^{71}$ Ha olyan részletes a szabályozás, hogy emiatt az alkalmazással is adódhatnak problémák, felmerül az a kérdés, hogy mennyiben van valódi súlya magának a benne foglalt rendelkezéseknek a gyakorlatban. Ahogy azt a VB megfogalmazta, sem a túl könnyen, sem a túl nehezen módosítható alkotmány nem biztosítja a megfelelő stabilitást. ${ }^{72}$

Az egyes államok között nagy eltérések mutatkoznak, és azt is szükséges figyelembe venni, hogy „a túl könnyü eljárás, mely nem választja el megfelelöen egymástól az egyszerü jogalkotást és az alkotmány elfogadását és módositását, és ezáltal megsérti a magasabb szintü egyetértés szükségességének elvét, lealacsonyítja a népszuverenitás eszméjét. A túl nehézkes eljárás viszont ellenkezik a szükséges hibák javitásának

módosithatják a felülvizsgálat alá nem vont rendelkezések terminológiáját avégett, hogy összhangba hozzák öket az új rendelkezések terminológiájával, és hogy összhangot biztositsanak az Alkotmány francia, holland és nemet szövege között.

Az ilyen esetekben a kamarák csak akkor tanácskozhatnak, ha az öket alkotó tagoknak legalább a kétharmada jelen van; és a módositások csak akkor fogadhatók el, ha megkapták a leadott szavazatoknak legalább a kétharmadát."

69 Behrendt, Christian: The Process of Constitutional Amendment in Belgium. In: ContaIDES, XenOPHON (szerk.), Engineering Constitutional Change, A Comparative Perspective on Europe, Canada and the USA, Routledge, 2013. 4-5. pp.

${ }^{70}$ Erre szolgálhatnak az ún. informális utak: bírósági értelmezés, alkotmányos szokás, stb.

71 Például Jakab András bemutat négy nemzetközileg bevett jogállamiság-indexet: JAKAB ANDRÁs: A jogállamiság mérése indexek segítségével. Iustum Aequum Salutare 2016/2. 196-204. pp.

${ }^{72}$ CDL AD (2010)001 21-22. pp. 
szükségességével, emberi tévedhetetlenséget feltételezve, megakadályozva a hatásos segitését a népszuverenitás érvényesülésének, amennyiben arra szükség mutatkozik. "73 Számos tényező befolyásolja egy alkotmány rugalmasságát, amelyek összességükben és külön-külön is meghatározóak lehetnek az alkotmány stabilitásának szempontjából, ahol a szélsőségek elkerülése fontos cél, hiszen az egyedi jellemzők figyelembe vétele mellett kell érvényesíteni az általánosan elfogadott alapelveket annak érdekében, hogy ideális egyensúly jöhessen létre a rugalmasság és a merevség között, lehetővé téve az aurea mediocritas fellelését.

${ }^{73}$ LuTZ, Donald S.: Toward a Theory of Constitutional Amendment in: LEVINSON, SANFORD (szerk.): Responding to Imperfection, The Theory and Practice of Constitutional Amendment, Princeton University Press, Princeton, New Jersey 1995. 240. p. 


\section{Történeti alapkérdések}

A modern alkotmányosság alapelvei visszavezethetőek a felvilágosodás gondolkodóinak munkáira is, elég csak a hatalmi ágak elválasztása vagy a népszuverenitás elméleteire gondolni. Emellett azonban felfedezhető ebben a korban is már az alkotmány stabilitásának kérdése. Ekkor sem volt egységes álláspont arra vonatkozóan, hogy melyik az előnyösebb: ha gyakran változtatható az alkotmányt, vagy ha ritkán. A kezdetekkor, azaz az egyik első alkotmány elfogadásakor már felmerült ez a kérdés, mégpedig az USA alkotmányához kapcsolódóan, egy Thomas Jefferson és James Madison között folytatott levélváltásban.

\subsection{Jefferson véleménye}

Jefferson 1789 szeptemberében levelében azt taglalta, hogy álláspontja szerint az alkotmány minden generációnak a sajátja, ezért lehetőséget kell biztosítani minden újabb generáció számára, hogy az alkotmányt saját képére formálhassa. Részletesen kifejtette véleményét a kérdésben, a következőkben a levélböl kiemelt részletek segítik megvilágítani elméletét.

„Úgy tünik, az a kérdés, hogy egy generációnak van-e joga egy másik generáció kezét megkötni [értsd: az alkotmány kérdésében, a szerző], még soha nem merült fel sem nálunk, sem az óceán túlsó partján. Pedig ez olyan kérdés, amelynek következményei nemcsak a döntés érdemét határozza meg, hanem minden kormány müködésének alapvetö elvei között is megtalálható. "74

Nem teljesen van igaza Jeffersonnak, hiszen például Arisztotelész is foglalkozott a kérdéssel, ha nem is generációkra vonatkoztatva a vizsgálatot, de a megváltoztathatóságot elemezte:

„Már ebböl is kitünik, hogy egyes törvényeket bizonyos esetekben meg kell változtatni; ugyanakkor más szempontból a változtatás, úgy látszik, nagy óvatosságot igényel. (...) De még ha kell is változtatni rajtuk, vajon valamennyin és az egész alkotmányon is? És vajon akárki jöttmentnek szabad-e, avagy csak egyeseknek? Mert ez nagy különbség ám!" 75

\footnotetext{
${ }^{74}$ BOYD 1950.

${ }^{75}$ ARISZTOTELÉSZ: Politika II. könyv Gondolat Kiadó, 1994, 8 pont.
} 
Azonban ez a kérdés valóban nem volt jellemző, különösen a klasszikus értelemben vett alkotmányjog-tudomány kialakulása előtt. Talán ennek oka a monarchikus berendezkedésű államok addigi egyeduralmában található, hiszen ahol az uralkodó személye általában generációnként változott, és az uralkodó személyének változása általában magával hozta a jogrendszer módosulását is, ott nem volt szükség ennek a vizsgálatára.

Ezzel szemben az új amerikai köztársaságban az alkotmány akár több generációt is szolgált, hiszen máig hatályos az eredetileg elfogadott alkotmány szövege, nemcsak bizonyos rendelkezései élnek tovább szokásjogi úton, bár a bírósági értelmezés sokszor új irányt szab az eredeti szöveg jelentésének. A preambulum pedig szövegszerüen tartalmazza azt az igényt, hogy az utókort is figyelembe vegyék. ${ }^{76}$ A kortársak azonban ezt nem tudhatták, és valóban felmerült a kérdés ebben a helyzetben. Jefferson álláspontja szerint: „,Megalapozásul a következőt állitom, amit magától értetődőnek tekintek: „a föld az élők ususfructusa”: a halottaknak nincsenek sem jogai, sem hatalma felette." 77

Álláspontja a holtkéz-elméletet ${ }^{78}$ vetíti rá az alkotmányra. E szerint egy hosszú távon hatályos alkotmány megköti a következő generáció kezét, megnehezítheti a kormányzást számukra, hiszen elég csak USA alkotmányára gondolni, ahol a 18. századi alapító atyák nem gondolhattak arra, hogy egyszer döntéseik alkalmazásra kerülnek olyan kérdések eldöntésére is, mint az abortusz vagy az azonos nemüek házassága. ${ }^{79}$ Ennek gyakorlati müködéséhez szükség van természetesen egy olyan bíróságra, mint az USA Legfelső Bírósága, amely képes úgy használni a rövid, néhol kicsit homályos rendelkezéseket, hogy egy USA méretű és bonyolultságú alkotmányos rendszer képes legyen funkcionálni ennek alapján. Ez, vagyis a bírói jogalkotás az amerikai jogrendszer létezésének alapja.

Tehát Jefferson véleménye alapján az élők uralma korlátozásoktól mentes, és ezt nemcsak az egyén, hanem a társadalom szempontjából is elengedhetetlennek tartja:

\footnotetext{
76 „elömozdítsuk a közjót, biztositsuk a szabadság áldásait magunk és utódaink számára” USA alkotmányának preambuluma

${ }^{77}$ BOYD 1950

78 Részletes elemzése a fogalomnak: SIEGEL, ReVA B.: Heller \& Originalism's Dead hand - In Theory and Practice, Yale Law School, Yale Law School Legal Scholarship Repository. 1-1-2009. 1399-1424. pp.; EASTERbrook, Frank H.: Textualism and the Dead Hand. University of Chicago Law School, Chicago Unbound, 1998. 1119-1126. pp.

79 Jane Roe, et al. v. Henry Wade, District Attorney of Dallas County, 1973; James Obergefell, et al., Petitioners v. Richard Hodges, Director, Ohio Department of Health, et al. 2015.
} 
„Ami igaz a társadalom minden tagjára egyénileg, az igaz rájuk kollektíve is, mivel az egész jogai nem lehetnek nagyobbak, mint az egyének jogainak összessége. "80 Elemzése során absztrakciókat is felhasznál érvei alátámasztására: „Ha elképzeljük, hogy egy generáció egy napon születik, lesz nagykorú, majd hal meg, és az ezt követö is, ha egy generáció adósságot hagy a következőre, akkor a holtak befolyásolják az élök életét. "81 Ekkor az elemzést adósság vállalásával állította párhuzamba. Ezután egy generáció időtartamát is kiszámította Jefferson, végül arra a következtetésre jutva, hogy 19 év az ideális időtartam, ${ }^{82}$ amelynél hosszabb időre nem lehet adósságot vállalni. ${ }^{83}$ Álláspontja szerint ezt érdemes lenne alkotmányba is foglalni, hogy sem a jogalkotó, sem maga a nemzet nem vállalhat nagyobb adósságot, mint amit saját korukban, vagy 19 éven belül vissza lehet fizetni.

Ennek a gondolatnak a mintájára vezeti le azt az elvet, hogy „egy társadalom sem készithet örökké érvényes alkotmányt, vagy örökké érvényes jogszabályt, mivel a föld mindig az élö generációé. Ők irányítják, és döntenek a hasznairól, ahogy kívánják, a használat ideje alatt. Ök saját maguk urai, ennek következményeként szabad a döntésük. Azonban az emberek és a tulajdon a kormány irányitása alá tartoznak. Az elödeik alkotmánya és a törvényei elévülnek természet szerint, és eltünnek, akárcsak azok, akik alkották öket. Ez megelözheti, hogy megszünjenek, mielött már nem önmaguk lennének. Tehát minden alkotmány és minden jog természetes módon hatályon kívül helyeződik 19

\footnotetext{
${ }^{80}$ BOYD 1950.

${ }^{81}$ BOYD 1950.

${ }^{82}$,The length of that term may be estimated from the tables of mortality, corrected by the circumstances of climate, occupation \&c. peculiar to the country of the contractors. Take, for instance, the table of M. de Buffon wherein he states 23,994 deaths, and the ages at which they happened. Suppose a society in which 23,994 persons are born every year, and live to the ages stated in this table. The conditions of that society will be as follows. 1st. It will consist constantly of 617,703. persons of all ages. 21y. Of those living at any one instant of time, one half will be dead in 24. years 8. months. 3dly. 1[8],675 will arrive every year at the age of 21. years complete. 41y. It will constantly have 348,417 persons of all ages above 21. years. 5ly. And the half of those of 21. years and upwards living at any one instant of time will be dead in 18. years 8. months, or say 19. years as the nearest integral number. Then 19. years is the term beyond which neither the representatives of a nation, nor even the whole nation itself assembled, can validly extend a debt." BOYD 1950.

83 „I suppose that the recieved opinion, that the public debts of one generation devolve on the next, has been suggested by our seeing habitually in private life that he who succeeds to lands is required to pay the debts of his ancestor or testator: without considering that this requisition is municipal only, not moral; flowing from the will of the society, which has found it convenient to appropriate lands, become vacant by the death of their occupant, on the condition of a paiment of his debts: but that between society and society, or generation and generation, there is no municipal obligation, no umpire but the law of nature. We seem not to have percieved that, by the law of nature, one generation is to another as one independant nation to another." BOYD 1950.
} 
év után. Ha ezen túl is kikényszeritésre kerül, az már nem a jog cselekedete, hanem az eröszaké." 84

Igazán érdekes, hogy miközben Jefferson 19 évben határozza meg ideális esetként egy alkotmány ,életét” - ami akkoriban egy emberöltö/generáció volt -, Zachary Elkins, Tom Ginsburg és James Melton kortárs amerikai alkotmányjogászok ugyanerre az eredményre jutnak statisztikai vizsgálódás segítségével. Minden rendelkezésükre álló alkotmányt megvizsgáltak 1789 és 2005 között meghatározott szempontrendszer szerint. ${ }^{85}$ Munkájuk végén azt az eredményt kapták, hogy a vizsgált alkotmányok élettartamának mediánja 19 év, tehát a jeffersoni jóslat meglepő módon önbeteljesítő. ${ }^{86}$ Arra a következtetésre jutottak, hogy a 17 éves alkotmány van leginkább „veszélyeztetve”, ha azt az időszakot „túléli”, utána nagyobb az esélye a hatályban maradásának. ${ }^{87}$ Emellett olyan szempontokat is vizsgálták, mint a különböző krízisek, valamint egyéb tényezők hatása az alkotmány ,életben maradására” ${ }^{88}$ A nagyszabású kutatás eredményeként számos olyan eredmény került napvilágra az alkotmányok élettartamára vonatkozóan, melyekre korábban nem volt példa. ${ }^{89}$ Számomra külön érdekes ebben az elemzésben, hogy statisztikai módszerek segítségével igyekeztek vizsgálni egy olyan kérdést, amelynek komplexitása pont abból adódik, hogy minden ország eltérő társadalmi-gazdasági-politikai történettel bír, és az alkotmányok is ettől egyediek, a különbözö hatások révén.

Egymáshoz hasonló alkotmányokat vetettek össze (Pakisztán - India, ${ }^{90}$ USA Franciaország ${ }^{91}$ ) azt kutatva, hogy a hasonló kiindulópontnak van-e valódi hatása az alkotmány utóéletében. Arra a következtetésre jutnak az amerikai példa vizsgálatánál, hogyha az első nagy erőpróbát nem bírta volna ki az alkotmány, akkor valószínűleg hatályon kívül került volna, ám azt „túlélve” megerősödött a pozíciója, és egyre tovább nőtt a mozdíthatatlansága. Másfelől születő állam volt, ahol fontos szempontnak minősült a mielőbbi összetartozás kialakítása az emberekben. A Legfelső Bíróság informális alkotmányértelemzésének szerepe is jelentős. Franciaországban ezzel szemben a túl nehéz megváltoztathatóság és a royalista-köztársasági hívek közötti

\footnotetext{
${ }^{84}$ BOYD 1950.

${ }^{85}$ ELKINS - GinSBURG -MELTON 2009, 122-129. pp.

${ }^{86}$ ELKINS - GINSBURG -MELTON 2009, 129. p.

${ }^{87}$ ELKINS - GINSBURG-MELTON 2009, 130. p.

${ }^{88}$ ELKINS - GINSBURG -MELTON 2009, 132-139. p.

${ }^{89}$ ELKINS - GINSBURG -MELTON 2009, 6-8 fejezet

${ }^{90}$ ELKINS - GinsBURG -MELTON 2009, 150-162. pp.

${ }^{91}$ ELKINS - GINSBURG-MELTON 2009, 162-171. pp.
} 
ellentétek sem segítették elő az alkotmány stabilitásának kialakulását, az ország nem volt úgy elszigetelve az esetleges külső hatásoktól, mint az USA. ${ }^{92}$ A szerzők szerint Franciaországban a Code Civil és a közigazgatás - ha részlegesen is - biztosította a folytatólagosságot az állami szervezetrendszerben az alkotmányok gyakori váltakozása mellett. ${ }^{93}$

Idézett szerzők végkövetkeztetésként megállapítják, hogy három szempont a legmeghatározóbb egy alkotmány tartósságának esetében: a rugalmasság, a specifikusság és az inkluzivitás. ${ }^{94}$

- rugalmasság: „(...) az alkotmány azon tulajdonsága, hogy hosszabb idötartamhoz képes igazodni, lehetővé teszi, hogy a változó körülményekhez alkalmazkodni tudjon és megakadályozza az idö előtti »halált«." 95

- specifikusság: „(...) mind a részletekre, mind az összességre utal, elösegíti az alkotmány érvényesitését azáltal, hogy megerösiti az egyetértést az alkotmány tartalmára és jelentésére vonatkozóan. "96

inkluzivitás:" arra a szerepre utal, melyet különbözö jelentös társadalmi csoportok játszottak az alkotmány elfogadásakor - nagyjából, minél több csoport vett részt az elökészitésben, annál hosszabb ideig marad várhatóan hatályban az alkotmány. "97

A három szempont kiemelkedő, bár egy alkotmány elfogadásakor nem lehet tudni, hogy ezek a körülmények mennyiben meghatározók, hiszen ha az alkotmányozáskor nagy volt az inkluzivitás, a specifikusság és a rugalmasság is, de pár év elteltével úgy változott az ország helyzete, hogy gyökeresen más lett a politikai-gazdasági státusz, mert ennek hatására meg kell változtatni az alkotmányt.

Elkins, Ginsburg és Melton szerint lehet pozitív következménye a folyamatnak: „, Van legalább kézzelfogható érv arra, hogy az intézményi frissités alkotmánycserével együtt fejlödéshez vezet. Néha, úgy sejtjük, hogy a magas törvény újrairrása terapeutikus és jelentös hatással lehet nemcsak az állampolgárok, hanem a vezetők számára is. "98

\footnotetext{
92 ELKINS - GINSBURG -MELTON 2009, 167. p.

${ }^{93}$ ELKINS - GINSBURG -MELTON 2009, 171. p.

${ }^{94}$ ELKINS - GINSBURG -MELTON 2009, 207. p.

${ }^{95}$ ELKINS - GINSBURG -MELTON 2009, 207. p.

${ }^{96}$ ELKINS - GINSBURG -MELTON 2009, 207. p.

${ }^{97}$ ELKINS - GINSBURG -MELTON 2009, 207-208. pp.

${ }^{98}$ ELKINS - GINSBURG -MELTON 2009, 209. p
} 
Végül arra a következtetésre jutnak, amelyre elöttük már többen is, s amely a VB gyakorlat alapján is kikristályosodott: az sem jó, ha túl merev, az sem jó, ha túl rugalmas az alkotmány: „Azonban, az is megállapitható, hogy vannak gyorsan porba hulló érvek is a merevséggel szemben: a túlságosan mozdithatatlan alap ahhoz vezet, hogy az alkotmányt nem veszik figyelembe vagy elmozditják. Azok az alkotmányok, melyek birnak bizonyos fokú rugalmassággal, felkeltik más csoportok érdeklödését funkcionalitásuk fenntartása érdekében és elegendö ösztönzést biztositanak ahhoz, hogy a dokumentum megmaradhasson a változások mellett is.". ${ }^{99}$ Ezek a faktorok természetesen nem jelentenek tökéletes megoldást minden esetre a már vázolt okok miatt, azonban mindenképpen jelentős szerepük van egy alkotmány stabilitásának meghatározásában.

Jefferson stabilitásra vonatkozó gondolatai összegzéséül a következőket írta: „,Ezekben az esetekben a jelen jogalkotója feljogositott arra, hogy meghatározza saját idejének keretét és intézményeit, de annál hosszabb idötartamra nem; és akár a hatalom jelenkori birtokosai, akár az ö öseik, bona fide vevői annak, amit az eladónak nem volt joga eladni.,"100

Amikor még alacsonyabb volt az átlagéletkor, és az élet ritmusa is lassúbb volt, Jefferson szerint a 19 év az a választóvonal, amellyel el lehet különíteni a generációkat, és meghatározni azt a végső pontot, amíg el lehet menni akár adósságvállalás, akár alkotmányos rendelkezések érvényesülésének végső határaként. Ha ennél tovább maradna egy rendelkezés a jogrendszer része, az természetes módon hatályon kívül helyeződne. Ezzel az elmélettel lehetővé válik annak a kérdésnek a vizsgálata is, hogy a jövő generációknak milyen szintü beleszólása van a jelen kérdéseibe, melyeknek következményei rájuk is kihatnak. Látható, hogy a „Brexit”-népszavazás eredményét követően számos választójoggal még nem rendelkező fiatal tüntetett, hogy kifejezze ellenérzését azzal a döntéssel szemben, amely hatalmas jelenőséggel lesz egész elkövetkezendő életekre, azonban nem volt beleszólásuk a döntésbe, mivel még nem érték el a választójoggal való rendelkezés alsó korhatárát. ${ }^{101}$ (A jövő generációk jogai ebből a szempontból valóban érdemesek részletesebb vizsgálatra, s az értekézésben ezt el is végzem majd.)

\footnotetext{
${ }^{99}$ ELKINS - GINSBURG -MELTON 2009, 209. p.

100 BOYD 1950.

101 BLOOM, DAN: Young voters wanted Brexit the least - and will have to live with it the longest http://www.mirror.co.uk/news/uk-news/young-voters-wanted-brexit-least-8271517
} 


\subsection{Madison véleménye}

Jefferson tehát nem volt híve az alkotmányos elvek több generációra való kiterjesztésének, viszont levelezőtársa, Madison vele ellentétes álláspontra helyezkedett a kérdésben, mikor 1790 februárjában válaszolt Jefferson fentiekben elemzett levelére, megfogalmazva véleményét a kérdésben:

„Bármennyire is elfogadható elméletben a doktrina egy alkotmány vonatkozásában, a gyakorlat néhány nagyon erös ellenérvet állit ezzel szemben. Egy ilyen gyakran felülvizsgált kormányzat nem válna változékonnyá, képes lenne visszatartani azokat az elöitéleteket, melyek az elödökre vonatkoznak, és amelyek valószinüleg hasznos támogatói a legracionálisabb kormánynak a legfelvilágosultabb időkben? Az ilyen periodikus felülvizsgálat nem tenné lehetővé a veszélyes pártok létrejöttét, melyeknek egyébként erre nem lenne esélye?"102

Nem ért egyet Jeffersonnal, hiszen valóban kétséges lehet egy meghatározott periodikus felülvizsgálata az alkotmányos rendszerben, amelyet az egyes pártok akár saját érdekeik támogatására hegyezhetnek ki a „kampányidőszakban”, eltérítve így a valódi kérdés vizsgálatától az érintetteket.

Fel kell tenni a kérdést, hogy valóban minden esetben üdvözítő megoldás-e az alkotmány tartóssága, stabilitása? A madisoni gondolat alapján alakult ki az az irányzat, amely szerint egy alkotmány stabilitásának kulcsa annak hosszában található, vagyis minél rövidebb maga a szöveg, annál tartósabb lesz az alkotmány is. Ezt a gondolatot cáfolja empirikus kutatással Hammons, aki arra az eredményre jutott adatelemzéssel, hogy a hosszabb szövegü alkotmányok tartósabbak. ${ }^{103}$

Majd Jefferson ususfructus elméletét is górcső alá vonta Madison:

„Ha a föld a természet ajándéka az élőknek, ez csak a föld természetes állapotára vonatkozhat. Azok a fejlesztések, melyeket az elödök végeztek, megbizás az élöknek, akik hasznát látják ezeknek. Ezt a megbizást nem lehet másképp elvégezni, mint az elödök akaratának végrehajtásával folytatni a fejlesztéseket. "104

Madison vizsgálta az élők és a holtak viszonyát is, csakhogy ebben a kérdésben is más eredményre jutott:

102 The Papers of James Madison. HutChInSON, WILliam T. ET AL. (szerk.) Chicago and London: University of Chicago Press, 1962-77 (vols. 1-10); Charlottesville: University Press of Virginia, 1977(vols. 11-)

103 Hammons, Christopher. Was James Madison Wrong? Rethinking the American Preference for Short, Framework-Oriented Constitution. American Political Science Review 93(4), 1999. 845. p.

${ }^{104}$ HUTCHINSON 1977. 
"Úgy tünik, hogy a dolgok természetének van egy menete abban a tekintetben, hogy egy generáció ráörökiti a következöre kötelezettségeit. Az egyenlöség megköveteli ezt, kölcsönös elönyök származnak belöle. Minden, ami elengedhetetlen az élök és a holtak közötti számla kiegyenlítéséhez, azt a célt szolgálja, hogy a tartozások az utóbbiakkal szemben ne szárnyalják túl az elöbbiek által létrehozott elönyöket." 105

$\mathrm{Az}$ egyenlőség elvének alkalmazása a generációk közötti kötelezettségekre vonatkoztatva azért vet fel kérdéseket, mivel a korábbi generáció nem feltétlenül tudhatta, hogy milyen körülmények között fog boldogulni a következő generáció, azonban döntéseivel meghatározta elöre azt az utat, melyen végig kell mennie majd az utódoknak, hiába változnak a körülmények akár jelentős módon is. Elég csak a jelenleg hatályos iraki alkotmányra gondolni, amelyet a háborút követően fogadtak el. ${ }^{106} \mathrm{~A}$ korábban hatályos szöveg és e között komoly eltérések mutatkoznak, és nem a természetes fejlődés áll e mögött, melyben a korábbi generációk iránymutatása jelenne meg. Egy-egy ilyen éles váltás az állami-társadalmi berendezkedésben felveti azt a kérdést, hogy valóban milyen jelentősége van a korábbi generációk által lefektetett szabályoknak. Álláspontom szerint ez attól függ, hogy a jelenlegi generáció hogyan viszonyul hozzájuk. Be akarja-e tartani a bennük foglaltakat, ugyanazon az úton akar tovább menni, vagy épp ellenkezőleg, homlokegyenest más irányba indul, teljes mértékben ellentmondva a korábbi rendelkezéseknek.

Organikus alkotmányfejlődés esetében korrekt lehet ez az érv, ám ez nem tekinthető tipikusnak, számos ország történelmében a forradalmi alkotmányozás általánosabb, mint az organikus fejlödés, tipikusan olyan történelmi eseményeket követ, melyek szakítanak a korábbi hagyományokkal, és pont az új alkotmányos rend kialakítása miatt kerül sor alkotmányozásra, melynek eredményeként megváltozik az adott ország alapvető müködése.

Madison álláspontja szerint, ha a törvényeket nem kényszerítik ki a 19 éves időtartam letelte után is, a legtöbb tulajdonjog diszfunkcionálissá válna, és eröszakosságig fajulna a régi és az új rendszer érdekeltjeinek harca: ${ }^{107}$

„Nem látok kiutat ezen következmények alól, de a doktrína szerint egy hallgatólagos hozzájárulást lehetne adni ezeknek az elfogadott alkotmányoknak és jogszabályoknak, és ez a hozzájárulás alkalmazható lenne abban az esetben, amikor nincs eröteljesen

\footnotetext{
105 HUTCHINSON 1977.

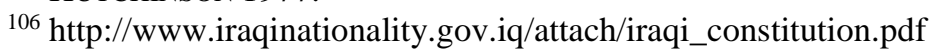

${ }^{107}$ HUTCHINSON 1977.
} 
eltérö vélemény. Inkább tünik praktikusnak a kormány bölcs tervei alapján orvosolni az elv veszélyes használatát, mint találni egy orvosságot egymástól elválaszthatatlan nehézségekre." 108

Ha egy generáció mégsem akarja tovább fejleszteni elődei alkotmányos munkáját, azt gyökeresen meg akarja változtatni, annak milyen körülményei vannak? Honnan lehet felismerni azt, hogy megjelent a társadalmi igény új alkotmány elfogadására vagy a meglevő jelentős módosítására valamely kérdésben? Erre válaszol Ackerman, akinek alkotmányos pillanat-elmélete szerint - részletesen lásd 5.5. alfejezet - a társadalomban megjelenő igény megkülönbözteti a „normál politikát” és a „különleges jogalkotást”, ${ }^{109}$ tehát jelentősen elválik egymástól a kettő, és ritkán alakul ki olyan szintű felfokozott társadalmi érdeklődés, mely alkotmányos pillanathoz vezetne. ${ }^{110}$

Gondolatai zárásaként az alábbiakat fogalmazza meg Madison:

„Nem lehet megkérdőjelezni, hogy lehetséges-e teljes mértékben kizárni a hallgatólagos hozzájárulás elméletét anélkül, hogy felforgatnánk a civil társadalom alapjait? Milyen indok alapján kötheti meg a többség a kisebbség kezét? Ez nem a természet törvényeiböl következik, hanem egy, a közös érdeket szolgáló, kompromisszumon alapuló megállapodásból. Nagyobb arányra lehet szükség egy társadalom alapját képezö alkotmány elfogadásához, ha azt megfelelönek itélik." 111

Madison más szemszögből látja a problémát, mint Jefferson, azonban véleményem szerint mindkettőjük gondolataiban van megfontolásra érdemes, hiszen valóban nem lehet olyan erős befolyást gyakorolni az eljövendő generációkra, hogy ne változzon semmilyen tekintetben az alkotmányos rendszer. Viszont az sem müködne a gyakorlatban, hogy 19 évenként teljes csere történjen. A jogrendszer folyamatos változásai ellenére a kontinuitás talaján áll, mivel az egyes jogszabályok mögött húzódó alapelvek változatlanok, amennyiben nem történik olyan társadalmi változás, mely magát az elvrendszert módosítja (mint például a kommunista hatalomátvétel során Magyarországon a második világháború után). A jogfolytonosság problémájára itt csak utalok. $^{112}$

\footnotetext{
108 HUTCHINSON 1977.

109 ACKerman, BruCE: We the People 1. Foundations. The Belknap Press of Harvard University Press, Cambridge, Massachusetts, London, England, 1993. 31-32. pp.

${ }^{110}$ Mint például a New Deal időszaka.

111 HUTCHINSON 1977.

${ }^{112}$ Lásd pl: VARGHA FERENCZ: Jogfolytonosság. Jogtudományi Közlöny, 1925/9, 66. p.
} 
Mi történik abban az esetben, ha a 19 éves periódus közepén következik be olyan súlyú társadalmi változás, melynek hatására szükséges az alkotmány módosítása? Nem lehetne alkotmányt módosítani, vagy új alkotmányt elfogadni, ha nem telt le a 19 év, mert ez a generáció fogadta el a szabályokat, akkor együtt is kell élniük választásukkal? Ezek a kérdések már mereven értelmezik az elméletet, azonban figyelembe veendő, hogy az alkotmányjog területén, különösen az alkotmányozás - alkotmánymódosítás kérdésében mindig tekintettel kell lenni a realitásokra. Az adott országban történő változások befolyásoljak az egész alkotmányos rendszert, így az alkotmány szövegét is. Hiszen hiába fogadtak el alkotmányt egy országban nem olyan régen, amikor megszünik például a diktatúra, az első dolog az lesz, hogy alkotmányozásba fogjanak, ezzel is hangsúlyozva, hogy elhatárolódnak a régi rendszertől, még akkor is, ha az előtte elfogadott alkotmány például csak 3 éve van hatályban. A valóság gyakran felülírja az elméletet, de az elmélet sokat segíthet a kialakuló helyzetek megfelelő értelmezésében, ha van mire támaszkodni, van ötlet, hogy milyen irányba lehet indulni, az segíti a gyakorlat színvonalát emelni.

\subsection{Paine véleménye}

Jefferson és Madison vitájában megnyugtató válasz azóta sem született, de mások figyelmét is felkeltette a probléma. Thomas Paine is foglalkozott a kérdéssel Dissertation on the First Principles of Government címü munkájában, amelyben az örökölt és a választott kormányok közötti különbségeket vizsgálta. Ebben a tekintetben Jefferson álláspontjára helyezkedett:

„Egy nemzet, bár folyamatosan létezik, állandóan a megújulás és a jogutódlás állapotában van, sohasem mozdulatlan. Minden nap új születéseket, felnötté válásokat, halálokat hoz. (...) Ha másképp vélekedünk ebben a kérdésben, akkor vagy szolgaként, vagy zsarnokként gondolkodunk. Szolgaként, ha úgy gondoljuk, hogy bármelyik korábbi generációnak joga volt megkötni a kezünk; zsarnokként, ha úgy gondoljuk, hogy jogunkban áll megkötni a következö generációk kezét." 113

Paine ezzel végeredményben köztes álláspontot foglal el a vitában, amivel egyet is tudok érteni ebből a szempontból, azonban a realitásokat figyelembe kell venni: nyilván befolyásolja az előző generáció cselekedeteinek eredménye az őket követő generációk

113 PAINE, THOMAS: Dissertation on the First Principles of Government, http://www.thomaspaine.org/major-works/dissertation-on-the-first-principles-of-government.html 
lehetőségeit. Hiába tételezzük fel a teljes szabadságot, meghatározott keretekből kell kiindulni, melyek az alapját képezik a lehetőségeknek.

Paine nem hisz abban, hogy a jelen generáció döntése olyan mértékben befolyásolhatja az eljövendő generációk alkotmányát, amelynek hatására kikerül a kezükből a változtatási lehetőség, azonban megvizsgálta ezt a hipotetikus esetet is:

„Minden korszaknak és generációnak jogában áll, hogy minden esetben szabadon döntsön, ahogy azt a megelözö kor és a generáció is tette. A síron túli kormányzás öntelt és a hiú gondolata a legnevetségesebb és legszemtelenebb minden zsarnokság közül." 114 Valóban nem lehet befolyásolni a következő generációkat abban, hogy miként határozzák meg saját alkotmányos identitásuk ${ }^{115}$, azonban egy generáció képes megkötni a következő generáció, vagy akár több generáció kezét az alkotmány megváltoztatásának tekintetében. Elég csak az USA alkotmányára utalni, ahol 228 év alatt összesen 27 alkotmánykiegészítést fogadtak el, tehát ha a tizenkilenc év-egy generáció arányt vesszük figyelembe, pontosan 12 generációo ${ }^{116}$ kezét kötötték meg az alapító atyák erősen, amikor meghatározták az alkotmány módosításának szabályait. Bár az informális alkotmányértelemzési módszerek igénybe vételével működőképes az alkotmány, igencsak be volt és van határolva a mozgási lehetőség az alkotmány keretei között a társadalom számára.

Gondolatai zárásaként a következőt jegyzi meg Paine:

„Azt az elvet, hogy ez idö szerint minden nemzetnek jogában áll úgy kormányozni, ahogy az neki tetszik, el kell ismernünk; de az örökletes kormányzás már más embercsoport feletti kormányzás, nem saját magunké; azok, akik ezt irányítják, még nem születtek meg, vagy kiskorúak, ezért a létezés joga sem biztosithatja a helyettük való döntést, valamint ilyen jog feltételezése is árulás az utódok jogaival szemben." 117

Paine álláspontja jól érzékelteti azt a dilemmát, hogyan határolható körül, hogy a jelen generáció milyen mértékben befolyásolhatja az eljövendő generációk lehetőségeit, hogy mennyire szükséges figyelembe venni az ő érdekeiket. Valóban szerteágazó kérdés,

\footnotetext{
${ }^{114}$ PAINE 1795.

115 Az alkotmányos identitás fogalmáról részletesen lásd például: SULYOK MÁRTON: Kettő az egyben? Alkotmány és identitás In: BALOGH ElEMÉR (szerk.): Számadás az Alaptörvényröl, Magyar Közlöny Lapés Könyvkiadó Kft., Budapest, 2016. 339-358. pp. KluG, HeINZ: Constitutional Identity and Change. Tulsa Law Review, 2011/47. 41-49. pp.; DRINÓCZI TímEA: Az alkotmányos identitásról. Mi lehet az értelme az alkotmányos identitás alkotmányjogi fogalmának? MTA Law Working Papers, 2016/15. 1-42. pp.

$11612 * 19=228$

117 PAINE 1795.
} 
hogy milyen módon lehet biztosítani a jövő nemzedékek érdekeinek megjelenítését a döntéshozatalban, mely kétség kívül hatást gyakorol majd az ö életükre, akik még nem tudnak vélemény formálni erről, mert mire képesek volnának rá, már nem jövő nemzedékként jelennek meg a folyamatban, hanem döntéshozóként, ezért ambivalens a kérdés.

Más szempontból támasztja alá az érvelést Noah Webster, aki szerint „Az Állam egy szuverén hatalom, amely sohasem hal meg. Hatalma, amikor a maga nevében cselekszik, minden idöben ugyanolyan kiterjedéssel bir; és ugyanolyan joga van hatályon kívül helyezni egy törvényt ebben az évben, mint amilyen joga volt az tavaly megalkotni. "118 Tehát Webster az állami hatalom minőségével magyarázza, hogy miért nem lehet megkötni a jövő generációk kezét, mivel „,(..) semmilyen alkotmány nem lehet megváltoztathatatlan egy szabad kormányzással rendelkezö országban. "119

\subsection{Jefferson véleményének változása}

Az évek múlásával, ahogy Jefferson látta a gyakorlatban müködni az alkotmányt, az új törvényeket, változás történt az alkotmány módosítására vonatkozó véleményében. 37 évvel a már bemutatott levél után Jefferson Samuel Kercheval Monticello számára írt levelében (1816. július 12.) ismét az alkotmányok megváltoztatásával, azok élettartamával foglalkozik:

„Néhányan álszent tisztelettel tekintenek az alkotmányokra és frigyládaként kezelik, mint amely túl becses ahhoz, hogy hozzá lehessen nyúlni. Az elöttük levö generációnak olyan bölcsességet tulajdonitanak, amely több, mint emberi, és úgy vélik, hogy döntéseiket nem lehet megváltoztatni. (...) Azonban azt is tudom, hogy a törvények és az alkotmány fejlödésének párhuzamosan kell haladnia az emberi elme fejlödésével. (...) Ahogy nem várhatjuk egy férfitöl, hogy a gyermekkorában ráillö kabátot hordja, a civilizált társadalomtól sem várható el, hogy örökre barbár öseik irányítása alatt maradjanak. "120

Jefferson 1816-ra finomított álláspontján, és úgy vélte, hogy nem kell kicserélni az egész alkotmányt és a törvények rendszerét, hanem 19 évente elegendő felülvizsgálni,

\footnotetext{
118 WEBSTER, NOAH (as “Giles Hickory”): On the Absurdity of a Bill of Rights. American Magazine (New York), December 1787, from the Debate on the Constitution (two volumes, Library of America, 1993), Volume 1. 670. p.

${ }^{119}$ WEBSTER 1787, 670.

120 The Letters of Thomas Jefferson 1743-1826: To Samuel Kercheval Monticello, July 12, 1816, http://www.let.rug.nl/usa/presidents/thomas-jefferson/letters-of-thomas-jefferson/jefl246.php
} 
és az adott generáció igényeihez igazítani azt, melynek következtében az tovább fog élni, akár az „,idők végezetéig”. Ez már olyan vélemény, melynek a hangsúlya a folytonosság, a stabilitás fenntartásán van, nem pedig a periodikus, gyökeres változtatáson:

„Minden generáció olyan független, mint az öt megelöző, ahogyan az minden korábbi generációra is igaz. (...) ebböl következöen, hogy alkalmazkodhasson a körülményekhez, melyek között találja magát, melyet a felmenöitöl kapott; és az emberiség békéjének és javának szolgálatára, szükséges, hogy ez a lehetőség minden tizenkilenc vagy húsz évben az alkotmány által biztositott legyen; hogy így tovább lehessen adni, periodikus javitásokkal, generációról generációra, az idők végezetéig, amennyiben valamely emberi tényezö képes ennyi ideig fennmaradni.,"121

A periodikus korrekciók már más szempontot mutatnak, de még mindig nem foglalkoznak azzal a kérdéssel, hogy mi történik abban az esetben, ha nem generációs váltáshoz köthető az alkotmányozás, alkotmánymódosítás megjelenésének szükségessége? Mi történt volna, ha az amerikai polgárháború lezárulta előtt 2 évvel lett volna a szokásos 19 éves vizsgálat? A háború végeztét követően nem tudták volna rendezni a szükséges kérdéseket? A racionalitást mindenképpen zászlajára kell tüzni annak, aki az alkotmányok megváltoztatásának szükségességét időintervallumban kívánja meghatározni.

Azonban egy ilyen vizsgálat kezdetekor nem mindig az a fó kérdés, hogy milyen gyakran kell és lehet megváltoztatni az alkotmányt, hanem hogy egyáltalán meg kell-e változtatni az alkotmányt, van-e igény, szükség erre. Arisztotelész szerint:

„Egyesek valóban kételkednek, vajon káros vagy hasznos-e a városállamnak, ha ösi törvényeit megbolygatják, mikor valami jobb kínálkozik. Már csak azért sem könnyü sebtiben csatlakozni ehhez a véleményhez, ha a változtatás valóban nem szokott használni. De az is lehetséges, hogy akadnak, akik a törvény s az alkotmány megbontását közhasznú cselekedetként ajánlják. "122

Tehát mindig alapos megfontolás tárgyává kell tenni azt, hogy valóban szükséges-e hozzányúlni az alkotmány szövegéhez, hiszen az alkotmány az egész jogrendszer alapja, megváltoztatása vagy új alkotmány elfogadása kihat az egész jogrendszerre, ezáltal a társadalomra is.

\footnotetext{
121 JEFFERSON 1816.

${ }^{122}$ ARISZTOTELÉSZ 8. pont
} 
A három gondolkodó megalapozta a kérdésre adható válaszokat, a vita azóta is folyamatos ezen a területen, hiszen az alkotmány tartóssága, a benne foglaltak tiszteletének szintje meghatározó lehet az egész alkotmányos rendszer stabilitásának tekintetében. Számos elmélet került kidolgozásra az alkotmány stabilitásának vonatkozásában, és mostanában kezd előtérbe kerülni a jövő generációk alkotmányos helyzetének vizsgálata. 


\section{A Velencei Bizottság értelmezése az alkotmány stabilitásáról}

\section{1 Általános elemzés}

A VB az Európa Tanács jogállami tanácsadó testületeként 1990-es müködése óta egyéb kérdések mellett számos esetben vizsgálta az Európa Tanács tagjainak alkotmányozási, alkotmánymódosítási folyamatait is. A vizsgálatok során komoly gyakorlati tapasztalat jött létre, melyet a testület 2009-ben ${ }^{123}$ és 2015-ben ${ }^{124}$ összegzett.

A VB fontos szempontnak tekintette, hogy az érintett államok az alkotmányozási, alkotmánymódosítási folyamat során is kapjanak segítséget, nemcsak a folyamatok lezárulta után fogalmazott meg kritikákat. Az átfogó elemzésekböl az alkotmány stabilitásával, merevségével/rugalmasságával kapcsolatos gondolatokat emelem ki.

A VB a megfelelő alkotmányos egyensúly elemzésekor felhívta a figyelmet arra, hogy mindig esetről esetre kell vizsgálni annak megfelelőségét, sem a túl merev, sem a túl rugalmas szabályok nem tekinthetők jó mintának, nincs egyetlen optimális modell. ${ }^{125}$ „Hangsúlyos, hogy nincs "varázsformula«. A kihívás az, hogy a merevség és a rugalmasság követelményei egyensúlyban legyenek." ${ }^{126}$ Mindig magát az adott alkotmányt kell vizsgálni, annak tulajdonságait és a környezetét, amely kialakulását, esetleges fejlődését befolyásolta. ${ }^{127}$ Ezen tulajdonságok közül az elemzés kiemeli az alkotmány eredetét, korát, részletességét és betartathatóságát. ${ }^{128}$

- Az eredettel kapcsolatban fontos hangsúlyozni, hogy különbséget tesz a demokratikus és a nem demokratikus környezetben elfogadott alkotmányok között, felhívva a figyelmet arra, hogy ez a tényező önmagában nem határozza meg azt, hogy az alkotmány később demokratikusnak minősül-e. ${ }^{129}$ Elég csak az USA és Németország, valamint Japán jelenleg hatályos, demokratikus, jogállami alkotmányainak elfogadására gondolni, ahol egyik esetben sem lehet megállapítani az eljárási szabályok betartását és a szabad döntési lehetőséget. ${ }^{130}$ Ajánlja a testület, hogy a demokratikus átmenetet élő országok tegyék könnyen

\footnotetext{
${ }^{123}$ CDL-AD(2010)001

${ }^{124}$ CDL-PI(2015) 23. p.

${ }^{125}$ CDL-AD(2010)001 21-22. pp.

${ }^{126}$ CDL-AD(2013)029 5. p.

${ }^{127}$ CDL-AD(2010)001 24. p.

${ }^{128}$ CDL-AD(2010)001 25-26. pp.

${ }^{129}$ CDL-AD(2010)001 25. p.

${ }^{130}$ JAKAB ANDRÁS: Mire jó egy alkotmány? Kommentár 2010/6.
} 
módosíthatóvá a szöveget, hogy megerősödhessen a legitimációjuk. ${ }^{131} \mathrm{Ha}$ a magyar alkotmányt vizsgáljuk, elég csak a rendszerváltozás során zajlott alkotmányos vitákra gondolni, amelyek eredményeként végül elfogadták az alkotmány átfogó módosítását, de a kiindulási pont egy nem demokratikus alkotmány volt, bár a dokumentum 20 évig szolgált egy demokrácia müködésének alapjaként.

- A kor kapcsán megállapítható, hogy ebben a kérdésben is nagy eltérések vannak az egyes európai országok között, több száz éves alkotmányoktól kezdve a legfrissebbekig. A legrégebbi máig hatályos európai alkotmányok a norvég és a holland, mindkettő 1814 óta van hatályban. ${ }^{132}$ A legújabb alkotmányok között található a magyar Alaptörvény. A régi demokráciákban nem jellemző új alkotmány elfogadása, a közép-kelet-európai országok nagy része pedig a rendszerváltozáskor elfogadott új alkotmánya mellett maradt az idők során. A balkáni és a még keletebbre fekvő országok alkotmányozási, alkotmánymódosítási gyakorlata már gyakrabban kerül a VB vizsgálatának kereszttüzébe. ${ }^{133}$

- A részletesség szempontjából fontos kiemelni, hogy minél részletesebb a szöveg, annál rugalmasabbnak kell lennie magának az alkotmánynak annak érdekében, hogy müködőképes legyen az alkotmányos rendszer: „Egy túlságosan terjengős alkotmány lehetetlenné teheti címzettjei számára, hogy megértsék, és elöirásainak megfelelöen cselekedjenek, ennek következtében nehezebbé válik kikényszeritése, nem pedig könnyebbé." 134 A VB szerint az átlagos európai alkotmány 100-200 szakasz közti terjedelmü. ${ }^{135}$ A magyar Alaptörvény hatodik módosítás utáni szövegét vizsgálva megállapítható, hogy 132 szakaszból áll, ${ }^{136}$ amivel az átlagmezőnybe kerül.

- Betartathatóság alatt az alkotmány bírói védelmét és értelmezését érti a VB, amely modern vívmánynak tekinthető Európában. ${ }^{137}$ Mára kifejezetten

\footnotetext{
${ }^{131}$ CDL-AD(2010)001 25. p.

${ }^{132}$ Hogyha nem vesszük figyelembe az ún. miniállamok alkotmányait, ugyanis San Marino alkotmánya 1244-es.

133 Például Örményország, Ukrajna, Moldova, Horvátország, Szerbia, Montenegró.

${ }^{134}$ ELKINS - GINSBURG-MELTON 2009, 210. p.

${ }^{135}$ CDL-AD(2010)001 26. p.

${ }^{136}$ Amennyiben a Záró és vegyes rendelkezések pontjait is különálló szakaszoknak tekintjük.

${ }^{137}$ CDL-AD(2010)001 26. p.
} 
elterjedtté vált, hogy az alkotmány védelméért külön szerv felel, legyen az akár alkotmánybíróság, akár a legfelső bírói testület.

A formális és informális alkotmánymódosítások közötti különbséget is figyelembe veszi a VB. ${ }^{138}$ A formális, vagyis az alkotmányba foglalt alkotmánymódosítási folyamatnak megfelelő alkotmánymódosítás mellett az informális alkotmánymódosítás három útját vizsgálja a testület, mégpedig a bírói értelmezéssel, az alkotmányos szokásokkal, konvenciókkal való módosítást, valamint az alkotmányos kultúra ilyen jellegü hatásait.

- A bírói értelmezéssel kapcsolatban kimondja a vélemény, hogy bár sok országban képes változást létrehozni az alkotmány értelmezési keretében a tagállamok közül, egyik szerepe sem olyan jelentős, mint az USA Legfelső Bíróságáe. ${ }^{139}$ Általában az adott ország alkotmánybírósága foglalkozik az alkotmány értelmezésével az európai országokban, amely modellként a VB által is támogatott. ${ }^{140}$ Ebben a bírói értelmezés nem rendelkezik olyan jelentőséggel, mint az USA-ban - különösen Nagy-Britanniára, ahol a parlamenti szupremácia érvényesül - azonban jelentősége így is meghatározó lehet egy-egy alkotmányba foglalt kérdés értelmezése során. Ha az adott testület aktív szerepet vállal, például a 23/1990 (X. 31.) AB határozat kifejezetten aktivista megnyilvánulás volt a magyar Alkotmánybíróság részéről.

- Az alkotmányos szokások hatására akár a szövegnek ellentmondó gyakorlat is kialakulhat. $^{141}$

- Az alkotmányos kultúra meghatározó elemei közé sorolja a testület az alkotmányértelmezés nemzeti szabályait, az alkotmány szimbolikus értékét többek között. ${ }^{142}$

Amíg a formális alkotmánymódosítás minden európai ország számára abszolút legális és elfogadott lehetőség - kivéve Nagy-Britanniát -, addig az informális alkotmánymódosítási módszerek megítélése már jelentősen eltérhet az egyes országok gyakorlatában. Egyes országokban nem müködik alkotmánybíróság, és a rendes bíróságok sem értelmezhetik az alkotmányt - például Hollandia -, más országokban ezzel szemben jelentős szerepe van az Alkotmánybíróságnak az alkotmányszöveg

${ }^{138}$ CDL-AD(2010)001 22-24. p.

${ }^{139} \mathrm{CDL}-\mathrm{AD}(2010) 001$ 22. $\mathrm{p}$.

${ }^{140} \mathrm{CDL}-\mathrm{AD}(2010) 001$ 23. p.

${ }^{141}$ CDL-AD(2010)001 23. p.

${ }^{142}$ CDL-AD(2010)001 24. p. 
értelmezésének kialakításában - lásd Németország -. Az alkotmányos szokások milyensége és kötőereje is nagy eltérést mutat, vannak országok, ahol elképzelhetetlen ezek áthágása - Nagy-Britannia -, és vannak olyan országok, ahol ezt könnyen megteheti valamely hatalmi ág - például Oroszország -. Így a kérdés vizsgálata különös gondosságot igényel.

\subsection{A Velencei Bizottság véleménye néhány konkrét ügyben}

A VB megannyi érintett ország alkotmányát vizsgálta, például a grúz, ${ }^{143}$ ukrán ${ }^{144}$ és kirgiz $^{145}$ alkotmányokkal kapcsolatban többször óva intett a testület a túl rugalmas alkotmánymódosítási szabályoknak köszönhető nagyon gyakori alkotmánymódosítás veszélyeitől, ${ }^{146}$ de attól is, hogy merev alkotmánymódosítási szabályokkal aránytalanul megnehezítsék az alkotmány módosítását. ${ }^{147}$

Belgium és Izland régi demokráciának számít, tipikusan nem a hosszú demokratikus történelemmel bíró országok vonatkozásában szokott vizsgálódni a VB. Azonban ahogy arra a VB is felhívja a figyelmet, „(...) még régi és érett alkotmányos rendszerek esetében is szükségessé válhat a megfelelö alkotmányreform a hatékony és demokratikus kormányzás elösegítésének érdekében”. ${ }^{148}$ Mindkét országnál problémaként jelent meg, hogy túl nehéz módosítani az alkotmányt. ${ }^{149}$

A belga alkotmánymódosítási szabályok valóban a legmerevebbek közé tartoznak az európai palettán. ${ }^{150}$ Komoly problémák alakultak ki az országban, mikor a nehézkes alkotmánymódosítási folyamat elakadt olyan kardinális kérdések terén, mint a régiók autonómiája, szövetségi választások, európai parlamenti választások, különböző nyelvhasználati kérdések. ${ }^{151}$ A VB megállapította, hogy nem sérült az alkotmányosság elve a módosítás során, pedig az átlagoshoz képest a belga alkotmány alkotmánymódosításra vonatkozó szabályai különösen merevek. ${ }^{152}$

\footnotetext{
${ }^{143} \mathrm{http} / / /$ www.venice.coe.int/WebForms/documents/by_opinion.aspx?lang=EN

$144 \mathrm{http}: / / \mathrm{www}$. venice.coe.int/WebForms/documents/by_opinion.aspx?lang=EN

145 http://www.venice.coe.int/WebForms/documents/by_opinion.aspx?lang=EN

146 Például Örményország, Horvátország.

${ }^{147}$ Például Szerbia, Belgium, Románia, Izland.

${ }^{148}$ CDL-AD(2010)001 40. p.

149 Belgium: 2 vélemény, CDL-AD(2012)010, CDL-AD(2002)001. Izland: 1 vélemény CDL$\mathrm{AD}(2013) 010$

${ }^{150}$ CDL-AD(2012) 010 6. p.

${ }^{151}$ CDL-AD(2012) 010 3.p.

${ }^{152}$ CDL-AD(2012) 010 6. p.
} 
Izland esetében a hatályos szabályozás szerint az alkotmány módosításához a parlament támogatására van szükség, majd új választásokat írnak ki, és ha az új parlament is elfogadja a szöveget, a módosítást elfogadják. A VB 2013-ban jelezte az akkor tervben levő alkotmánytervezettel kapcsolatban véleményét. A tervezett szabályozás szerint az alkotmánymódosításhoz a parlament jóváhagyása után népszavazásra van szükség alapesetben, a II. fejezetre vonatkozó esetben pedig két egymást követő parlament támogatása után kerülne sor népszavazásra. ${ }^{153} \mathrm{~A} \mathrm{VB}$ álláspontja szerint a tervezet alkotmánymódosításra vonatkozó szabályai túlságosan merevek, főleg a két egymást követő parlament általi jóváhagyást követő népszavazás miatt. A vélemény szerint „,(...) ha a tervezetet elfogadják [az alkotmánymódosítási szabályok tekintetében, a szerző.], szinte biztos, hogy politikailag lehetetlen lesz a módositás, mivel a szavazók nem fognak lemondani az új hatalomról, amit csak épp megkaptak." ${ }^{154}$ Bár az új izlandi alkotmányt végül nem fogadták el, máig az 1944-ben elfogadott alkotmány maradt hatályban, ${ }^{155}$ megállapítható, hogy az alkotmány módosításának szabályai egy stabil, régi demokrácia esetén sem feltétlenül lesznek megfelelőek, függetlenül a jogállamiság szintjétől az adott országban, sőt, a belga példára utalva, az is lehet, hogy komoly gondokat okoz a túl merev alkotmánymódosítási szabály a gyakorlatban.

Az érem másik oldala a túl könnyen módosítható alkotmány problémája. A VB ettől is óva inti az államokat, mivel azok negatívan befolyásolhatják az alkotmányos és politikai stabilitást. ${ }^{156}$ Horvátország esetében egy 2001-es VB-i vélemény állapította meg, hogy a Felsőház megszüntetésekor nemcsak az adott okot az aggodalomra, hogy nagyon rövid időintervallumon belül kétszer módosították az alkotmányt, hanem az is, hogy a módosítások könnyebbé tették az alkotmány módosítását. Ez az alkotmány stabilitásának gyengüléséhez vezethet. ${ }^{157}$ A jelenleg hatályos rendelkezések szerint sincs felsőháza a horvát parlamentnek, bár ez nem okozott olyan szintű gyengülést az ország alkotmányos stabilitásában, ahogy annak lehetőségét előre jelezte véleményében a VB.

\footnotetext{
${ }^{153}$ CDL-AD(2013)010 29. p.

${ }^{154}$ CDL-AD(2013)010 30. p.

$155 \mathrm{http}: / / \mathrm{www}$. government.is/constitution/

${ }^{156}$ CDL-AD(2010)001 22. p.

${ }^{157}$ CDL-INF (2001)15 5. p.
} 
2007-ben a VB Montenegró új alkotmányát vizsgálta, melyben az alkotmánymódosítás szabályaival is foglalkozott többek között. ${ }^{158}$ Ebben jelenik meg az a gondolat, hogy veszélyezteti az alkotmány stabilitását, ha a parlamentnek joga van egy teljesen új alkotmányt elfogadni. ${ }^{159}$

A legfrissebb, alkotmányozást, alkotmánymódosítást is tárgyaló döntése a VB-nak, amely az alkotmány stabilitásának szempontjából is releváns, Kazahsztánhoz köthető.

Egy alkotmánymódosítással kapcsolatban azt állapította meg a VB, hogy pozitív, ha az Alkotmánytanács jogosultságot kap arra, hogy az alkotmánymódosításokat megvizsgálhassa, mielőtt azokat elfogadják, abban a vonatkozásban, hogy „az ország egységét, területét, kormányformáját és függetlenségét érintő rendelkezéseket nem lehet megváltoztatni". ${ }^{160}$ Ám javasolja a testület a lista kiegészítését a demokratikus kormányformával és az elidegeníthetetlen alkotmányos jogokkal. ${ }^{161}$

A törökországi alkotmánymódosítással kapcsolatban azt vizsgálta a $\mathrm{VB}$, hogy amikor egy országban rendkívüli időszak/jogrend alakul ki, lehet-e ennek során az alkotmányt módosítani, az milyen befolyással van az alkotmány stabilitására. ${ }^{162}$

A vizsgálat zárásaként a VB a következő kijelentést tette: „(...) minden alkotmányos rendszernek elég rugalmas szabályokkal kellene rendelkeznie ahhoz, hogy alkalmazkodni tudjon a politikai és szociális változásokhoz, és elég merevnek ahhoz, hogy biztositsa az alkotmányos legitimáció érvényesülését."163 Ez minden alkotmányozó, alkotmánymódosító hatalomnak iránymutatásul szolgálhat, miként az arany középút felé mutató, empirikusan tapasztalatokon alapuló gondolat.

\subsection{A Velencei Bizottság a magyar Alaptörvényről}

Bár a VB vizsgálta egyszer 2011 előtt az Alkotmányt, ${ }^{164}$ azóta pedig háromszor vizsgálta az Alaptörvényt, ${ }^{165,166}$ ezeket a véleményeket a következőkben az alkotmány stabilitásával, az alkotmányozással, alkotmánymódosítással kapcsolatban vizsgáljuk

\footnotetext{
${ }^{158}$ CDL-AD(2007)047

${ }^{159}$ CDL-AD(2007)047 18. p.

${ }^{160}$ CDL-AD(2017)010 7. p.

${ }^{161}$ CDL-AD(2017)010 7. p.

${ }^{162}$ CDL-AD(2017)005 7-11.pp.

${ }^{163}$ CDL-AD (2010)001 40. p.

${ }^{164}$ CDL-INF(1996)002

${ }^{165}$ CDL-AD(2011)001, CDL-AD(2011)016, CDL-AD(2013)012

166 Más kérdésekben is vizsgálódott 2011 óta a VB, például CDL-AD(2012)001, CDL-AD(2012)008, CDL-AD(2012)020, CDL-AD(2017)015
} 
meg, az egyéb lehetséges vizsgálati szempontokat mellőzve, melyek kaptak már figyelmet. ${ }^{167}$

A CDL-AD (2011)001 véleményében a VB magyar kormány által az alkotmányozási folyamatban feltett három kérdésre válaszolt. ${ }^{168} \mathrm{~A}$ VB nem látta az alkotmánytervezet szövegét, úgy készült el a válasz, amit többször is hangsúlyoz véleményében a testület. ${ }^{169} \mathrm{Az}$ actio popularis és az ex ante normakontroll, valamint az alapjogi katalógus konkrét kérdéseinek vizsgálata mellett ${ }^{170}$ a VB tett néhány általános megállapítást az alkotmányozási folyamatról. Ezek szerint a testület aggodalmát fejezi ki, hogy a 2011. április 18-án elfogadni tervezett alkotmány szövege nem volt nyilvános 2011. március 14. napjáig, ami korlátozott társadalmi vitát tett csak lehetővé. ${ }^{171} \mathrm{~A}$ VB felhívta a figyelmet arra, hogy „(...) az átláthatóság, a nyitottság, a kizárólagosság elkerülése, a megfelelö időkeret és a feltételek, amelyek biztositják a nézetek pluralizmusának érvényesülését, valamint az ellentmondásos kérdések megfelelö megvitatásának lehetöségét, kulcselemei a demokratikus alkotmányozási folyamatnak." "172 Ezért kell elkerülni a túl rövid határidejü vitát egy alkotmány elfogadásának során. Trócsányi felhívja a figyelmet arra, hogy „az alkotmány megvitatására rendelkezésre álló idö önmagában nem perdöntö az alkotmány legitimációját illetően", ${ }^{173}$ mert vannak olyan alkotmányok, amelyek elfogadásukkor nem feleltek meg a kritériumoknak, mégis az idő múlásával alkalmassá váltak feladatuk ellátására, mint például a hatályos francia alkotmány elfogadáskor is sokan temették a köztársaságot. ${ }^{174}$

A VB konklúziói között tünteti fel az alábbi gondolatot: „A fokozott rugalmasság, nyitottság és kompromisszumra készség kulcsfontosságú minden érdekelt számára, és lehetővé kellene válnia annak, hogy politikai háttértől és orientációtól függetlenül szabályos és fenntartható alkotmányt fogadjanak el, amely megfelel a demokratikus standardoknak és a magyar társadalom széleskörü támogatását élvezi."175 Ennek

167 Például: TRÓCSÁNYI 2014, 110-123, 225-277.; RENÁTA UITZ: Can you tell when an illiberal democracy is in the making? An appeal to comparative constitutional scholarship from Hungary. International Journal of Constitutional Law, Volume 13, Issue 1, 1 January 2015. 279-300. pp.

${ }^{168}$ CDL-AD(2011)001 4. p.

${ }^{169}$ CDL-AD(2011)001 3-4. pp.

${ }^{170}$ CDL-AD(2011001 5-13. pp.

${ }^{171}$ CDL-AD(2011)001 5. p.

172 CDL-AD(2011)001 5. p.

173 TRÓCSÁNYI 2014, 113. p.

174 ÁDÁM PÉTER: Franciaország alkotmányos rendje és politikai intézményei. Corvina, 2007,18-21. pp.

${ }^{175}$ CDL-AD(2011)001 13. p. 
megvalósítása utópisztikusnak tünhet, ${ }^{176}$ azonban a törekvésnek legalább olyan szinten meg kell jelennie, amely a jogállamiság és a demokrácia alapkövetelményeinek biztosításához elengedhetetlen.

A már elfogadott Alaptörvény első vizsgálatakor ${ }^{177}$ a VB nem foglalkozott sem az alkotmányozás, sem az alkotmánymódosítás kérdésével, csak a vélemény elején tett megjegyzést arra, hogy az alkotmányozásnak ki kell emelkedni a megszokott politikai folyamatok közül, ${ }^{178}$ és annak teljes sikeréhez a lehető legszélesebb körű konszenzus szükséges. ${ }^{179}$

Az Alaptörvény negyedik módosításának vizsgálatával kapcsolatban számos vitás kérdés felmerült. ${ }^{180} \mathrm{~A}$ véleményből ismét csak az alkotmányos stabilitás szempontjából releváns kérdéseket emeljük ki, különös tekintettel az Alkotmánybíróság hatáskörére, bár maga az alkotmánymódosítás témája is érinti ezt a területet.

Az egyik legkiemelkedőbb kérdés ugyanis pont az volt, hogy miképpen befolyásolja az alkotmányosságot az alkotmánymódosítások arra való felhasználása, hogy bizonyos rendelkezéseket az alkotmányszövegbe emelve kerüljék ki az alkotmánybírósági vizsgálatot, különös tekintettel azokra, amelyekről már korábban döntött a testület, megállapítva alkotmánysértő voltukat. A VB kiemelte, hogy az a gyakorlat, amely szisztematikusan a rendes jogalkotásra tartozó kérdéseket alkotmányba emeléssel kezel, megelőzve az alkotmánybírósági normakontrollt, veszélyezteti a fékek és egyensúlyok rendszerét. ${ }^{181}$

Az Alkotmánybíróság alkotmánymódosítások feletti kontrollja elvezet az alkotmányellenes alkotmánymódosítások kérdéséhez. Itt csak annyit jegyeznék meg, hogy a VB áttekintette az erre vonatkozó európai gyakorlatot, és megállapította, hogy nem általános ilyen jellegü jogkört biztosítani az alkotmánybíróságoknak, de nem példa nélküli. ${ }^{182}$

\footnotetext{
176 TRÓCSÁNYI 2014,114. p.

177 CDL-AD(2011)016

${ }^{178}$ CDL-AD(2011)016 4. p.

${ }^{179}$ CDL-AD(2011)016 5. p.

180 A teljesség igénye nélkül: Fö fenntartások Magyarország Alaptörvényének negyedik módositásával kapcsolatban

https://tasz.hu/files/tasz/imce/fo_fenntartasok_magyarorszag_alaptorvenyenek_negyedik_modositasaval_ kapcsolatban_fin.pdf; Az alapvető jogok biztosának Alkotmánybírósághoz fordulása ez ügyben: 12/2013 (V. 24.) AB határozat, GÁva KRISZTiÁN: Az Alaptörvény módositásai. Pro Publico Bono, 2014/2, 34-43. pp.; TRÓCSÁNYI 2014, 89-90. pp.

${ }_{181}$ CDL-AD(2013)012 20.p.

${ }^{182}$ CDL-AD(2013)012 23-24. p.
} 
A VB felhívta a figyelmet arra, hogy az 1949. évi XX. törvény 12 módosítása 20102012 között, az Alaptörvény 4 módosítása alig több, mint egy év alatt és az Átmeneti Rendelkezések szerteágazó módosító hatásai aggodalomra adnak okot. Az alkotmány nem csupán egy politikai eszköz, hanem a jogrendszer alapja. ${ }^{183}$ Többek között e vélemény hatására fogadták el az Alaptörvény ötödik módosítását, mely konszolidálta a helyzetet, és a legproblematikusabb részek, melyeknél a VB jelezte az európai értékek veszélybe kerülését, ${ }^{184}$ kikerültek az Alaptörvény szövegéből. ${ }^{185}$

A VB véleményét ebben a kérdésben az Európa Tanács fötitkára és a magyar külügyminiszter is kérte, számos kiegészítő dokumentum és vizsgálati anyag született. ${ }^{186}$ Emellett a hazai alkotmányjogi szakirodalom is felfokozott érdeklődéssel fordult az eljárás felé, egy amicus levél is született számos közremüködő munkájának eredményeként. ${ }^{187} \mathrm{~A}$ vizsgált területről az a megállapítás született, hogy bár eddig nem volt alkotmányszövegbe foglalt felhatalmazása az Alkotmánybíróságnak az alkotmánymódosítások vizsgálatára, és el is zárkózott tőle, éppen a közelmúlt alkotmányos eseményei miatt jelent meg az alkotmány egységének védelmét szolgáló tartalmi vizsgálat gondolata, melyet a kizárólagos formai vizsgálat alkotmányba emelésével az alkotmányozó kizárt. ${ }^{188}$

Összességében tehát a VB vizsgálatai hozzájárultak az Alaptörvény ötödik módosításának elfogadásához. A testület több kritikát is megfogalmazott az Alaptörvénnyel szemben. Mivel a VB-nek nincs hatásköre kikényszeríthető döntést hozni, nem minden ajánlása került elfogadásra, azonban több is felhasználásra került. A VB, ahogy a többi tagállami alkotmány vizsgálata során, a magyar ügyekben is a jogállamiság egységes európai standardjainak védelme mellett tette le voksát.

\footnotetext{
${ }^{183}$ CDL-AD(2013)012 30. p.

${ }^{184}$ CDL-AD(2013)012 31-32.pp.

185 TRÓCSÁNYI 2014, 119-124. p.

${ }^{186}$ CDL-AD(2013)012 3-5. pp.

${ }^{187}$ BÁNKUTI MikLós et al. Amicus Brief a Velencei Bizottságnak az Alaptörvény negyedik módosításáról. Fundamentum 2013/3., 5-36. pp.

${ }^{188}$ BÁNKUTI 2013, 24-25. pp.
} 


\section{Alkotmányozás és alkotmánymódosítás elhatárolása stabilitási szempontból}

Az alkotmányozás és az alkotmánymódosítás közötti viszony vizsgálata elengedhetetlen az alkotmány stabilitásának elemzése során, mivel ez a különbségtétele alapozza meg az elválasztás gondolatát, vagy annak ellenkezőjét.

Manapság teljesen elfogadott az alkotmány módosításának eljárása, ha változnak a körülmények, szükséges, hogy az alkotmány szövege megfeleljen a változásoknak, kellően rugalmas legyen az új igények kielégítéséhez. Ez lehet az egyik oka annak, hogy az USA alkotmánya már nem annyira népszerü példa az alkotmányozásra készülő országok számára, ${ }^{189}$ ahogy az USA Legfelső Bírósága is kezdi elveszíteni központi szerepét a mintaadásban, ${ }^{190}$ mivel alkotmánya nem alkalmas megfelelő, erős értelmező szerv nélkül a modern demokrácia elemeit kiteljesíteni, alapjogi katalógusa például elég szegényes a modern alapjogi katalógusokhoz képest.

Ha az alkotmányszöveg tartalmaz konkrét kijelentést arra vonatkozóan, hogy eltérő módon lehet az alkotmány módosítását, valamint a teljes alkotmányrevíziót megvalósítani, ${ }^{191}$ akkor nem merül fel probléma. Az örökkévalósági klauzulák léte is arra enged következtetni egy alkotmányszövegben, hogy két különböző eljárásról van szó. ${ }^{192}$ Azonban vannak olyan országok, amelyek alkotmánya hallgat a kérdésről, ebben az esetben válik különösen érdekessé a tárgykör, hiszen nincs egyértelmü szabályozás.

Az alkotmányozás és az alkotmánymódosítás közötti különbség „,atyjának” Sieyés abbét tartják, aki „Mi a harmadik rend?” című írásában fogalmazta meg az alkotmányozó hatalom (pouvoir constituant) és az alkotmánymódosító hatalom (pouvoir constituant institué) közötti különbséget. E szerint elkülönül egymástól az alkotmányozó és az alkotmánymódosító hatalom, mivel alkotmányt csak az alkotmányozó hatalom hozhat létre. ${ }^{193}$ Célja az volt, hogy ezzel az elválasztással alapot biztosítson a népszuverenitásnak, és azóta is főleg ebből a célból teszik meg az elhatárolást, hiszen ha a nép az alkotmányozó, az alkotmány módosításával a parlament nem hozhat teljesen

\footnotetext{
189 http://mult-kor.hu/20120222_mar_nem_olyan_vonzo_az_amerikai_alkotmany

${ }^{190}$ BARAK, AHARON: A Judge on Judging: The Role of a Supreme Court in a Democracy. 116 Harvard Law Review 19. (2002) 27. p.

191 Például az osztrák alkotmány megkülönböztetést tesz.

192 Hiszen ha vannak módosítással meg nem változtatható részei az alkotmánynak, abból $a b$ ovo következik, hogy vannak módosítással megváltoztatható részei, tehát két különböző eljárásról van szó.

193 SIEYÉS, EMMANUEL-JOSEPH: What is the Third Estate? 1789, http://pages.uoregon.edu/dluebke/301ModernEurope/Sieyes3dEstate.pdf
} 
ellentétes döntéseket a szuverénnel szemben. Bár az elméletet nem ő írta le először, ${ }^{194}$ ő tette korlátlanná az alkotmányozó hatalmat elméletében, a konkrét helyzetnek megfelelő eredmény elérése érdekében. ${ }^{195}$

Az alkotmányozás és az alkotmánymódosítás közötti különbségtétel lehetségességét azóta sokan vizsgálták a külföldi szakirodalomban, ${ }^{196}$ a következőkben csak néhányat emelek ki a legfontosabbak közül.

Carl Schmitt alkotmányelméletéből csak az alkotmányozó hatalomra vonatkozó részeket vizsgálom Constitutional Theory című művéből. Schmitt szerint az alkotmány az alkotmányozó hatalomból származik, melyet a politikai egység hozott létre, ennek hatására jön létre az alkotmány, amely megváltoztathatja magát. ${ }^{197}$ Az alkotmány módosításáról a következő a véleménye: megkülönbözteti a rendes törvényhozástól, megállapítja, hogy nem korlátlan, mivel az alkotmány határozza meg határait, az alkotmánymódosítás nem változtathatja meg az alkotmány egészét. ${ }^{198}$

A következő elhatárolásokat teszi az alkotmánymódosítással kapcsolatban:

- az alkotmánymódosítás nem alkotmányos „megsemmisítése”199

- az alkotmánymódosítás nem az alkotmány „kiküszöbölése”200

- az alkotmánymódosítás nem az alkotmány törvénnyel való megsértése ${ }^{201}$

- $\quad$ az alkotmánymódosítás nem az alkotmány felfüggesztése ${ }^{202}$

Schmitt szerint az alkotmánymódosítás tehát az alkotmány által korlátozott, abban fundamentális változást nem hozhat létre, csak bizonyos határokon belül módosíthatja az eredeti dokumentumot.

Holmes és Sunstein az 1989 utáni kelet-európai alkotmányos változásokat vizsgálták, és arra a következtetésre jutottak, hogy szükséges éles elhatárolást tenni, és bár az

\footnotetext{
${ }^{194}$ Lásd: ROZNAI 2017, 107-108. pp.

${ }^{195}$ ROZNAI 2017, 107. p.

196 A teljesség igény nélkül: RASCH - CONGLETON 2006, 536-561. pp.; LUTZ, DONALD S.: Toward a Theory of Constitutional Amendment, American Political Science Review, Vol. 88., No. 2, June 1994. 355-370. pp.; EKeli, Kristian SKagen: How Difficult Should it be to Amend Constitutional Laws? Scandinavian Studies in Law, 2007/52. 80-101. pp.; LOUGHLIN, MARTIN: The Concept of Constituent Power. Critical Analysis of Law Workshop, University of Toronto, 15 Jan 2013. 1-24. pp.; TUSHNET, MARK: Peasants with pitchforks, and toilers with Twitter: Constitutional revolutions and the constituent power. International Journal of Constitutional Law (2015), Vol. 13 No. 3. 639-654. pp.

197 SCHMITT, CARL: Constitutional Theory. Translated and edited by Jeffrey Seitzer. Duke University Press, Durham and London, 2008. 75. p.

198 SCHMITT 2008, 150. p.

${ }^{199}$ SCHMITT 2008, 150. p.

${ }^{200}$ SCHMITT 2008, 151. p.

${ }^{201}$ SCHMITT 2008, 154. p.

${ }^{202}$ SCHMITT 2008, 156. p.
} 
általános minta azt mutatja, hogy könnyü megváltoztatni az alkotmányt ezekben az országokban, a jelentős változások szempontjából ez nem biztos, hogy probléma. ${ }^{203}$ Álláspontjuk szerint az alkotmányt megváltoztathatósága teszi legitimmé, mert fennmarad a lehetőség megváltoztathatóságára. Ha a változó viszonyok között van demokratikus út a módosítások rögzítésére az alkotmányban, akkor előny lehet a flexibilitás. ${ }^{204}$ Mivel a rendszerváltozás után nagyon változó volt a politikai, gazdasági, társadalmi helyzet ezekben az országokban, a könnyebb alkotmánymódosítás lehetőséget biztosított arra, hogy tudjon alkalmazkodni maga az alkotmány is a viszonylag gyors alkotmányos változásokhoz.

Preuss ezzel szemben úgy véli, hogy az alkotmányozó hatalom megalkotja az alkotmányt, majd eltünik, vagyis az alkotmány testesíti meg ezt a hatalmat megalkotásától, csak ezen keresztül gyakorolhatják hatalmuk. Ezért álláspontja szerint az alkotmánymódosítót ugyanakkora hatalommal kell felruházni, mint az alkotmányozót, ,Csak az a különbség a módositó hatalom és az alkotmányozó hatalom között, hogy az elöbbinek az alkotmány keretei között kell hatalmát gyakorolnia.". ${ }^{205}$ Tehát Preuss ebben látja az elhatárolást az alkotmánymódosítás és az alkotmányozás között, hogy az alkotmánymódosító hatalom nem léphet túl az alkotmányozó hatalom által felvázolt kereteken. ${ }^{206}$

Manapság az alkotmányozás kérdése felmerül fel a legfrissebb diskurzusban is, az alkotmányos felhatalmazás (constitutional authority) helyzetével a nemzeti és a transznacionális szinten, ${ }^{207}$ valamint a normativisták és a decizionisták vitájában. ${ }^{208}$

Yaniv Roznai egy új gondolattal kínál megoldást a problémára. Eszerint az alkotmánymódosító hatalom elkülönül az alkotmányozó hatalomtól, sui generis hatalom, de segítségével az alkotmányozó megosztja hatalma egy részét a jövő generációkkal annak érdekében, hogy minden generációnak legyen lehetősége élni

\footnotetext{
${ }^{203}$ HOLMES, STEPHEN - SUNSTEIN, CASS R.: The Politics of Constitutional Revision in Eastern Europe. in: SANFORD LEVINSON (szerk.): Responding to Imperfection, The Theory and Practice of Constitutional Amendment. Princeton University Press, Princeton, New Jersey 1995. 275. p.

${ }^{204}$ HOLMES - SUNSTEIN 1995, 277. p

${ }^{205}$ Preuss, UlRICH K.: The Implications of „eternity clauses”: the German Experience. Israel Law Review, 44, 2011. 434. p.

${ }^{206}$ PREUSS 2011, 434. p.

207 SomeK, AleXANDer: The Constituent Power in a National and in a Transnational Context 3(1) Transnational Legal Theory (2012) U Iowa Legal Studies Research Paper No. 12-35.

${ }^{208}$ WALKER, NEIL: The return of constituent power: A reply to Matthias Kumm. International Journal of Constitutional Law 2016 Vol. 14. 906. p.
} 
ezzel. $^{209} \mathrm{Az}$ alkotmányozó és az alkotmánymódosító hatalom közti kapcsolatot a megbízó és az ügynök viszonyával állítja párhuzamba: az ügynök mindent megtehet, amire felhatalmazást kapott, a megbízó nevében cselekszik, de nem léphet túl megbízatásán. ${ }^{210}$

Érvelését az alábbiakkal támasztja alá:

- „az alkotmánymódositó hatalom az alkotmányhoz kötött ${ }^{\text {,211 }}$

- „a legtöbb alkotmány eltérö szabályt tartalmaz az alkotmány módosítására, mint a rendes törvényhozásra. "212

- az alkotmány megváltoztatásának joga az alkotmányozó hatalom gyakorlása, de mivel az alkotmány által korlátozott, nem teljes körü, mint az alkotmányozó hatalom. ${ }^{213}$

Az alkotmányozás és az alkotmánymódosítás viszonya több szempontból vizsgálható, jelen munkában csak azokat a gondolatokat vizsgáltam, amelyek előremutatóak abba az irányba, hogy külön szükséges kezelni az alkotmánymódosítást az alkotmányozástól, mivel a két eljárás eltér egymástól, de a rendes törvényalkotástól való elhatárolás mindenképpen szükséges. Az alkotmányozás és az alkotmánymódosítás sokrétű viszony régóta foglalkoztatja a gondolkodókat, azonban nem célom ezek teljeskörü bemutatása, hanem csak a fő gondolat jobb megvilágításának céljából szükséges elméletek kerültek vizsgálatra.

\subsection{Alkotmányozás és alkotmánymódosítás elválasztása a hazai alkotmányos rendszerben}

A magyar alkotmányjogi gondolkodás nem vette át ezt az eszmét, csak az Alaptörvény elfogadása óta került a szakirodalmi vitában jobban elötérbe ez az elv. A történeti előzményeket Bihari Mihály vizsgálta ezen a területen. ${ }^{214}$

Ennek magyar viszonyokra való alkalmazása Jakab András szerint a következő három előfeltétel megvalósulása esetén lehetséges: a népszuverenitás elfogadása, a hatalommegosztás eszméje és az alkotmánymódosítás eljárásban a nép részvétele, vagy

\footnotetext{
${ }^{209}$ ROZNAI 2017, 111. p.

${ }^{210}$ ROZNAI 2017, 119-120. pp.

${ }^{211}$ ROZNAI 2017, 111. p.

212 ROZNAI 2017, 111. p.

${ }^{213}$ ROZNAI 2017, 112. p.

214 BIHARI MihÁly: Az alkotmányozó hatalomról in: TAKÁCS IMRE (szerk.): Az alkotmányozás jogi kérdései. Az Eötvös Loránd Tudományegyetem és a linzi Johannes Kepler Egyetem 1995. július 6-7-én tartott alkotmányjogi szimpóziuma Bp. ELTE-Eötvös K. 1995. 225-227. pp.
} 
legalábbis annak fikciója. ${ }^{215} \mathrm{Az}$ 1949. évi XX. törvény esetében a harmadik előfeltétel nem valósult meg. Ha megvizsgáljuk ezt a három előfeltételt jelen helyzetben, megállapítható, hogy a népszuverenitás elfogadott -B) cikk (3) bekezdés-, a hatalommegosztás is megvalósul -C) cikk (1) bekezdés-, valamint fikciós szinten megjelenik a Nemzeti Hitvallásban a nemzet is - „Mi, a magyar nemzet tagjai”, végig többes számban van a Nemzeti Hitvallás megszövegezve, stb. -. Tehát mindhárom előfeltétel megvalósult, beszélhetünk az alkotmányozó és az alkotmánymódosító hatalom elhatárolásáról a magyar alkotmányos rendszerben?

Álláspontom szerint nem, mivel maga az Alaptörvény határozza meg az alkotmány módosítására, illetve új alkotmány elfogadására vonatkozó szabályokat - azokat a S) cikkbe foglalva-, és egy teljesen logikus formai kitételtől ${ }^{216}$ eltekintve ugyanazok a rendelkezések vonatkoznak a két eljárásra. Nincs különbség sem a kezdeményezésben, sem a szavazás menetében, arányaiban, sem a formai felülvizsgálat vonatkozásában. Megállapítható, hogy az alkotmányozás és az alkotmánymódosítás ugyanolyan szabályok szerint zajlik, tehát nem állt szándékában az alkotmányozónak különbséget tenni a két eljárás között. ${ }^{217}$

A textuális és az jogalkotó szándéka szerinti értelmezés mellett azonban figyelembe kell venni azt a szempontot is, amely szerint az alkotmányozás és az alkotmány módosítása olyan nagymértékben eltérő rangúak, súlyúak, eltérő hatással bírnak egy ország alkotmányos rendszerére, hogy megkülönböztetésük szükséges, magától értetődő.

Ha áttekintjük a magyar szakirodalmi álláspontokat, a következő tabló alakítható ki:

Rácz Attila szerint a korábbi alkotmányos szabályozás határait csak alkotmányozással lehet túllépni, ha a módosítás már szétfeszítené a korábbi alkotmányos kereteket. ${ }^{218}$

Trócsányi László felhívja a figyelmet arra az esetre, amikor nem is lehet megfelelően elválasztani a két metódust, mivel folyamatos alkotmánymódosítás hatására jön létre alkotmányozás, ahogy az Magyarországon is történt a rendszerváltozás során. ${ }^{219}$

215 SzENTE ET AL.: [Az Országgyülés hatáskörei] In: JAKAB ANDRÁs (szerk.): Az Alkotmány kommentárja, I., Századvég Kiadó, Budapest, 2009. [111]

${ }^{216}$ S) cikk ,,(4) Az Alaptörvény módositásának kihirdetés során történő megjelölése a címet, a módositás sorszámát és a kihirdetés napját foglalja magában."

217 Az eljárási szabályokról részletesen lásd: ERDÖS CSABA: Rubiconon innen... és túl? Az Alkotmánybiróság gyakorlata az alkotmánymódositások felülvizsgálatának és az alkotmányi szabályok közti kollizió feloldásának területein. in: GÁRDOS-OROSZ FRUZSINA - SZENTE ZOLTÁN (szerk.): Jog és politika határán. Alkotmánybíráskodás Magyarországon 2010 után. HVG-ORAC Kiadó, 2015, 321-324. pp.

${ }^{218}$ RÁCZ ATTILA: Az Alkotmány megváltoztatásának módozatai. In: RÁCZ ATTILA (szerk.): Jogforrások az új alkotmányban. Közgazdasági és Jogi Könyvkiadó, Budapest, 1995, 123. p. 
Samu Mihály szerint az alkotmányozó hatalom jogosult alkotmányozni és az alkotmánymódosítást végrehajtani is, azonban feljogosíthat más szervet is módosításra, de maga a jog erre az alkotmányozó kezében van. ${ }^{220}$

Holló András álláspontja alapján az alkotmányozó hatalom az alkotmány megalkotásában és módosításában nyilvánul meg, ezt a véleményét az alkotmánymódosítások alkotmánybírósági felülvizsgálata kérdésének elbírálásakor több alkotmánybírósági határozatban is kifejtette. ${ }^{221}$

Sólyom László összefoglalja az Alkotmánybíróság első évtizedének gyakorlatát a kérdésben, amely szerint csak formális szempontból vizsgálódik a testület, és nem választja el az alkotmányozást és az alkotmánymódosítást. ${ }^{222}$

Varga Zs. András álláspontja szerint a különbség a „szakadási pont” megléte. Úgy véli, ha van szakadási pont, akkor nagy mélységü és intenzitású a változás, valamint a legalitás és a legitimitás is meghatározó tulajdonság. ${ }^{223}$

Petrétei József szerint az alkotmánymódosító hatalom csak az alkotmányozó által felvázolt keretek közt mozoghat, be kell tartania az alkotmányozó hatalom által meghatározott szabályokat. ${ }^{224}$

Részletes elemző munkája kimutatja, hogy „az alkotmányozó hatalom nincs kötve az alkotmányhoz, mivel alkotmányteremtő hatalom.," ${ }^{225}$ valamint felhívja a figyelmet konszenzus fontosságára. ${ }^{226} \mathrm{Az}$ alkotmánymódosító hatalom álláspontja szerint alkotmányjogi felhatalmazás alapján történik, ${ }^{227}$ tehát a két fogalmat el kell választani egymástól.

Az alkotmányozás és az alkotmánymódosítás közötti különbséget a minőségben fedezi fel a Csink-Fröhlich szerzőpáros. Álláspontjuk szerint a különbség abban található,

219 TRÓCSÁNYI LÁSZLÓ: Az alkotmányozás elvi kérdései. Acta Universitatis Szegediensis: Acta juridica et politica, 47. Tom. 1-18. Fasc. / 1996, Az alkotmányozás elvi, történeti, tételes és összehasonlító jogi problémái: a kar munkatársainak tanulmányai 1. rész. 174. p.

${ }^{220}$ SAMU 1997, 48-49. p.

${ }^{221}$ HOLLÓ ANDRÁs: Az alkotmánybiróság viszonya az alkotmányhoz: Az alkotmányozó és a törvényhozó hatalom elhatárolása. In: PETRÉTEI JÓZSEF (szerk.): Emlékkönyv Ádám Antal egyetemi tanár születésének 70. évfordulójára. Pécs: Dialóg Campus, 2000, (Studia iuridica auctoritate Universitatis Pécs publicata) 95. p.

${ }^{222}$ SÓLYOM LÁSZLÓ: Az alkotmánybíráskodás kezdetei Magyarországon. Osiris, 2001, 276-281. pp.

${ }^{223}$ VARGA Zs. 2009, 95-96. pp.

224 PETRÉTEI 2011, 78. p.

225 PETRÉTEI JÓZSEF: Az alkotmányozó hatalom és az alkotmányosság. in: GÁRDOS-OROSZ FRUZSINA SZENTE ZOLTÁN (szerk.): Alkotmányozás és alkotmányjogi változások Európában és Magyarországon, Nemzeti Közszolgálati Egyetem Közigazgatás-tudományi Kar Budapest, 2014. 51. p.

226 PETRÉTEI 2014, 56. p.

${ }^{227}$ PETRÉTEI 2014, 62. p. 
„,hogy míg az utóbbit [alkotmánymódosító hatalmat, a szerző] a jog, addig az előbbit más logikai rendszer legitimálja. "228

Más szerző amellett érvel, hogy népszavazással, a szuverén közvetlen bevonásával kellene alkotmányozni. ${ }^{229}$

Drinóczi Tímea meghatározza az általa követendőnek tartott demokratikus alkotmányozási eljárás szükséges lépéseit, ${ }^{230}$ és az Alaptörvény vonatkozó rendelkezéseit, valamint az azokról született elméleteket és részletes elemzés alá vonja. $^{231}$

A Bragyova - Gárdos-Orosz szerzőpáros szerint miközben az alkotmány meghatározza a saját módosítására vonatkozó szabályokat, amely már maga is kérdéseket vet fel, megállapítják, hogy valójában az alkotmány a szuverén, mivel saját magára vonatkozó szabályokat állapít meg. ${ }^{232}$

Látható tehát, hogy a magyar szakirodalomban sokféle vélemény alakult ki, amelyek részben változtak, részben ellentmondanak egymásnak, mivel valóban nem fekete-fehér ennek a kérdésnek a megítélése, ugyanis maga a konkrét alkotmányos helyzet járhat olyan következményekkel, amelyek hatására nem egyértelmü a válasz, hiszen a konkrét szöveg értelmezése mellett szükséges az adott ország politikai, jogi, társadalmi, gazdasági körülményeinek figyelembe vétele is.

Véleményem szerint a magyar alkotmányos rendszerben valóban nem valósul meg az alkotmányozó és alkotmánymódosító hatalom elválasztása, viszont azokban az országokban, ahol vannak örökkévalósági klauzulák, szükséges ezek elválasztása, mivel az örökkévalósági klauzulákat csak alkotmányozással lehet megváltoztatni, alkotmánymódosítással pedig nem, ez is szempont a két eljárás megkülönböztetésénél. Ha hazánkban is lennének örökkévalósági klauzulák, azok is egy szempontot képeznének az elhatároláshoz, hiszen az örökkévalósági klauzulák megváltoztatása

${ }^{228}$ CSINK LÓRÁNT - FRÖHLICH JOHANNA: Egy alkotmány margójára Alkotmányelméleti és értelmezési kérdések az Alaptörvényröl. Gondolat Kiadó, Budapest, 2012, 54. p

229 ÁDÁM ANTAL: Az alkotmányozásról. In: FEKETE BALÁZS - HORVÁTHY BALÁZS - KREISZ BRIGITTA (szerk.): A világ mi magunk vagyunk... Liber Amicorum Imre Vörös. HvgOrac Lap- és Könyvkiadó Kft., 2014. 153-154. pp.

${ }^{230}$ DRINÓCZI TíMEA: Többszintü alkotmányosság müködésben - alkotmányos párbeszéd Magyarországon. Akadémiai nagydoktori thesis, Pécsi Tudományegyetem, 2016, 103-105. pp

${ }^{231}$ DRINÓCZI 2015, 366-372. pp.

232 BRAGYOVA - GÁRDOS-OROSZ 2016, 39-40. pp. 
valóban szétfeszíti az alkotmányos berendezkedést, alkotmányozó hatalom szükséges megváltoztatásukhoz.

Ehhez az elhatároláshoz szolgál megoldással Yaniv Roznai, akinek álláspontja szerint az alkotmánymódosító hatalom egy sui generis hatalom, mert el kell határolni mind az alkotmányozástól, mind a rendes törvényhozástól, mert különbözik azoktól. ${ }^{233} \mathrm{Ez}$ a gondolat megoldással szolgálhat abban az esetben is, ha nincs örökkévalósági klauzula az alkotmányban ahhoz, hogy el lehessen határolni az alkotmányozást az alkotmánymódosítástól. Ha külön kezeljük mind az alkotmányozástól, mind a rendes törvényhozástól, lehetőség nyílik arra, hogy sajátosságainak megfelelően kezeljük, hiszen valóban átmenetet képez.

Összegzésképpen megállapítható, hogy korántsem egyszerü meghatározni az alkotmánymódosító hatalom természetét. Annak különleges voltát kiindulópontként tekintve, elhatárolva mind az alkotmányozástól, mind a rendes törvényhozástól, megállapítható, hogy érdemes megfontolni Roznai érveit, és akár az Alaptörvénybe foglalt szabályozás ellenére elkülönülten kezelni az alkotmánymódosító hatalmat annak speciális jellemzői okán.

A képet árnyalja az is, hogy miként húzzuk meg a határvonalat az alkotmány kismértékü módosítása és az alkotmány átfogó módosítása között. Ebben az esetben egy átfogó módosítás de facto alkotmányozásnak minősülhet, ha teljes mértékben megváltoztatja az adott alkotmány alapvető jellemzőit. Minden módosítás változtat az alkotmányon, azonban az alkotmány koherenciájának, főbb alapelveinek megváltoztatása esetében már lehetséges, hogy az alkotmánymódosításon belül is kialakítható két külön kategória, a „kisebb” és a „nagyobb” alkotmánymódosítás, vagyis az alapvető és nem alapvető következményekkel járó alkotmánymódosítások, mint ahogy az az osztrák Alkotmánybíróság gyakorlatában kialakult. ${ }^{234}$ Úgy vélem, hogy az alkotmány alapvető megváltoztatásával járó alkotmánymódosítás valójában már alkotmányozásnak minősül, ahogy az a rendszerváltozáskor Magyarországon történt, hiszen egy teljesen új értékekre épülő, más elveket magáénak valló, alapvetően eltérő jellegü alkotmány jött létre főbb alkotmánymódosítások után, amely, ahogy az

\footnotetext{
${ }^{233}$ ROZNAI 2017, 113. p.

${ }^{234}$ Lásd Gözler, KeMAl: Judicial Review of Constitutional Amendments, A Comparative Study. Ekin Press, Bursa, 2008. 94. p. 34-40. pp.
} 
Alkotmánybíróság fogalmazott 11/1992 (III. 5.) határozatában: „Az 1989. október 23án kihirdetett alkotmánymódosítással gyakorlatilag új alkotmány lépett hatályba, ". ${ }^{235}$ Úgy vélem, hogy az alkotmánymódosító és az alkotmányozó hatalom két különböző entitás, egymástól elválasztott kezelésük szükséges. Azonban a magyar Alaptörvény együtt kezeli a két folyamatot, nem tesz köztük különbséget. A gyakorlat a nem elválasztó fogalom-használatot támogatja, de magában a folyamatban válik el a két fogalom egymástól, hiszen egy alkotmánymódosítás más súllyal, jelentőséggel, következményekkel bír, mint egy alkotmányozás, akkor is, ha más címkével rendelkezik, a valós események alapján általában meg lehet állapítani, hogy az egyedi esetben alkotmányozás vagy alkotmánymódosítás történt, ezért elméletben is szükséges külön kezelésük. Egyetértek Roznai álláspontjával a kérdésben.

Ezt követem a különböző garanciák vizsgálatánál, mivel bizonyos garanciáknál van jelentősége annak a kérdésnek, hogy elkülönítve kezeljük-e a két definíciót.

235 11/1992 (III. 5) ABH 1992, 77. 


\section{A sziklára épített házról, vagyis az alkotmány stabilitásáról szóló elméletekről}

Az alkotmány stabilitásával kapcsolatban számos elméletet dolgoztak ki, sok jogtudós és gyakorlati szakember vizsgálta már különböző szempontok alapján, hogy melyek lehetnek a befolyásoló tényezői annak, hogy az adott ország alaptörvénye milyen gyakran változik. ${ }^{236}$ Ezek közül mutatom be azokat a releváns elméleteket, amelyeket leginkább alkalmazhatónak találtam a vizsgálatra, vagy azokat, amelyek a modern alkotmánytörténetben való gyakorlati megvalósulásuk alapján tanulságul szolgálhatnak a magyar alkotmányos események vizsgálatakor. ${ }^{237}$

\section{1 Átmeneti alkotmányok}

Az átmeneti alkotmányok kivételt képeznek az általános tétel alól, amely szerint egy alkotmány hosszú távra szól. Az alkotmány időtállóságának kérdése megszokott módon abból a szempontból merül fel, hogy minél hosszabb távon képes hatályban maradni, az annál előnyösebb lehet az adott ország jogi-társadalmi-gazdasági berendezkedésének szempontjából, vagy ha nem lehet megváltoztatni, megnehezíti a fejlődés alkotmányi szinten való megjelenését.

Ezt a problémát közelíti meg friss szemmel Varol, aki az átmeneti alkotmányok előnyeit emeli ki. ${ }^{238}$ Ezek előtt érdemes megnézni, hogy a szerző szerint mi az átmeneti alkotmány: olyan alkotmány vagy alkotmányos rendelkezés, amely „meghatározza saját hatályosságának idötartamát, és annak leteltével hatályát veszti, kivéve, ha rendes alkotmánymódositási eljárás keretében újra el nem fogadják.”. ${ }^{239}$ Tehát már maga a dokumentum vagy annak egy része tartalmaz arra vonatkozó rendelkezést, hogy átmeneti jellegű. Legismertebb példája ennek a jelenségnek talán a Németországi Szövetségi Köztársaság 1949-es alaptörvénye, amely saját átmenetiségét a 146. cikkben határozta meg:

\footnotetext{
236 Átfogó elemzés: ELKINS - GiNSBURG - MELTON 2009, például 65-92. pp.

${ }^{237}$ A kapcsolódó magyar elméletek (alkotmány megváltoztathatósága) stabilitási szempontú vizsgálata már szétfeszítené e munka kereteit, csak az alkotmányozás-alkotmánymódosítás viszonyával kapcsolatos magyar véleményeket mutatom be a 4. fejezetben.

${ }^{238}$ VAROL, OZAN O.: Temporary Constitutions. (April 29, 2013). 102 California Law Review 409 (2014), 414. p.

${ }^{239}$ VAROL 2014, 412. p.
} 
„A jelen alaptörvény, mely a német egység és szabadság megteremtését követöen az egész német népre nézve érvényes lesz, hatályát veszti azon a napon, amelyen a német nép szabad elhatározásával elfogadott alkotmány hatályba lép. "240

Emellett más példa is hozható, ${ }^{241}$ akár a magyar 1949. XX. törvény 1989-es módosításával hatályba lépett új preambuluma, mely szerint:

„A többpártrendszert, a parlamenti demokráciát és a szociális piacgazdaságot megvalósitó jogállamba való békés politikai átmenet elösegitése érdekében az Országgyülés - hazánk új Alkotmányának elfogadásáig - Magyarország Alkotmányának szövegét a következök szerint állapitja meg: "242

A magyar alkotmány preambuluma utalt arra a körülményre, mely szerint a kialakult helyzetben elfogadtak egy rövid távra szóló, kompromisszumos megoldást, melyet később majd egy új alkotmány követ, és kidolgozásához így megteremtették a kellő időt, elkerülték a helyzet radikalizálódását. Az, hogy a kellő idő 20 év volt a rendszerváltozás során az alkotmánymódosítást előkészítők elképzelése szerint, igencsak kérdéses, azonban a szándék az alkotmány módosítására többször is megjelent 1990-2010 között. ${ }^{243}$ Ugyanakkor az Alkotmánybíróság alkalmassá tette az 1949. XX. törvényt arra, hogy egy jogállam alkotmánya legyen. ${ }^{244}$ Számos módosítása is segítette a tovább élését, ${ }^{245}$ de érződött a szövegen és az egész szerkezeten, hogy nem demokratikus egyeztetés eredményeként jött létre, nincs meg a szükséges koherencia, $s$ bár az Alkotmánybíróság igyekezett azt megteremteni, magában a szövegben felfedezhető hiányosságokat nem tudták pótolni. A magyar „stabilitási helyzetnek” itt csak az átmeneti alkotmány szempontjából releváns részkérdéseit vizsgálom.

Ezért említem röviden az Alaptörvény Átmeneti Rendelkezéseit, melyek közül azért semmisített meg az Alkotmánybíróság többet is, ${ }^{246}$ mivel nem feleltek meg ennek a

\footnotetext{
240 Németországi Szövetségi Köztársaság Alkotmánya 146. cikk

${ }^{241}$ Például Portugália és Lengyelország alkotmánya.

242 1989. évi XXXI törvény az Alkotmány módosításáról

${ }^{243}$ Lásd pl.: BRAGYOVA ANDRÁS: Az új alkotmány egy koncepciója. Közgazdasági és Jogi Könyvkiadó, MTA Állam- és Jogtudományi Intézet, Budapest, 1995. 17-25. pp.; KUKORELLI IsTVÁN: $A z$ alkotmányozás évtizede Közjogi, politikai tanulmányok, parlamenti jegyzetek, Korona Kiadó, Budapest, 1995, 50-57. pp.; Összefoglaló a próbálkozásokról: ANTAL ATTILA: Alkotmányozási korszakok és technikák. Közjogi Szemle 2013/2. 3-6. pp.

Petrétei József igazságügyi miniszterként készített alkotmány-tervezetének nyilvánossága körüli vitákat lásd például: http://nol.hu/archivum/archiv-431485-240727

${ }^{244}$ SÓLYOM 2001, 223-227. pp.

245 Összesen 26 alkotmánymódosítás történt 1989-2009 között KUKORELLI IsTVÁN: Húsz éve alkotmányozunk... Közjogi Szemle 2009/3. 5. p.

246 45/2012 (XII. 29.) AB harározat [136] „Az Alkotmánybíróság ebböl következően az Ár.-nak a kommunista diktatúrából a demokráciába való átmenetről szóló részét (preambulumát), 1-4. cikkét, 11.
} 
kritériumnak. ${ }^{247}$ Az ÁR-nek más hiányosságait is feltárta az Alkotmánybíróság, ${ }^{248}$ jelen szempontból az átmenetiség majdnem alkotmányos szinten (,a közjogi senkiföldjén”) 249 jelent meg. Az ÁR-t kifejezetten az átmeneti időszakhoz kapcsolódó, valóban átmeneti kérdések rendezésére szánták, azonban többszöri módosítás eredményeként „,kis alaptörvénnyé" vált, nem átmeneti alkotmányos kérdéseket is szabályozva, ${ }^{250}$ ezzel nem alkotmányos szinten létrehozva az átmeneti alkotmányt, ennek hatására semmisítette meg az Alkotmánybíróság a nem átmeneti részeket. Majd a negyedik Alaptörvénymódosítás megszüntette ezt az unikális rendszert, amikor inkorporálta az ÁR meghatározott rendelkezéseit. Az átmenetiség ilyen speciális módon, az alkotmány szövegén kívül jelent meg a magyar rendszerben.

Az a célja az átmeneti rendelkezéseknek Varol szerint, hogy biztosítsák az átmenetet addig, míg a zavaros, esetleg forradalmi időszak után az alkotmányos rendelkezések kidolgozására megfelelő idő és figyelem jut. Ennek eléréséhez szükség van bizonyos minimumokra, amelyeket az átmenetiségük tesz könnyebben elfogadhatóvá minden érintett számára.

Varol álláspontja szerint az átmeneti alkotmány fő előnyei a következők:

- támogatja/elösegíti az inkrementalizmust ${ }^{251}$ és a kísérletezést,

- csökkenti a kognitív elfogultságot, amikor azok előre meghatározzák az alkotmányos mintakövetést,

- elősegíti a konszenzus kialakítását, amikor a döntés „ára” magas,

cikk (3) és (4) bekezdését, 12., 13., 18., 21., 22. cikkeit, 23.cikk (1) és (3)-(5) bekezdéseit, 27. cikkét, 28. cikk (3) bekezdését, 29. cikkét, 31. cikk (2) bekezdését valamint 32. cikkét megsemmisitette."

${ }^{247}$ Részletesen lásd: SZAKÁLy ZsUZSA: Transitional or Permanent? The Transitional Provisions of the Fundamental Law of Hungary. Days of Law 2013 Konferenciakötet, http://www.law.muni.cz/sborniky/dny_prava_2013/07_Soudy_a_soudnictvi_v_historickem_kontextu.pdf 369-370.

248 45/2012 (XII. 29.) AB harározat ,[51] Az Ár. a benne foglalt szabályozás átmenetisége ellenére a hatályba lépését követöen több alkalommal is módositásra került. (...) Az Ár. és annak módositásai megbontották az Alaptörvény egységét, az Alaptörvény mellett létrejött egy "kis Alaptörvény". Az Ar.-ba az Alaptörvény szabályozási tárgykörébe nem tartozó, attól idegen elemek is bekerültek. Az Ár. az Alaptörvényt helyettesitö törvénnyé vált: az Alaptörvény módositása helyett, amelyre az Alaptörvény S) cikk alapján és a beépülési parancs teljesitésével kerülhetne sor, elegendövé vált az Ár. módositása, ezen keresztül bármikor és bármilyen szabályozási tárgykörbe tartozó szabályozás az Alaptörvény "részévé" válhat, inkorporáció nélkül. Az Alkotmánybíróság az ilyen "Alaptörvényt helyettesito"”, az Alaptörvény egységét és szerkezetét megbontó, annak szabályozási tárgykörét és tartalmát nyitottá tevo", az Alkotmánybiróság hatáskörét "elvonó törvény" formai szempontú felülvizsgálatára hatáskörrel rendelkezik."

249 45/2012 (XII. 29.) AB harározat [73]

${ }^{250} 45 / 2012$ (XII. 29.) AB harározat [51]

${ }^{251}$ VAROL 2014, 421-427. pp. 
- lazít a „holtkéz”-problémán az alkotmányozók átmeneti kontrolljának enyhítésével. ${ }^{252}$

Varol tehát belátja, hogy az átmeneti alkotmány nem nyújt megoldást minden esetre, és a pozitívumokat felvázolva mutatja be előnyeit más utakkal szemben. Nem titkolja, hogy az átmeneti alkotmány vagy alkotmányos rendelkezés sem tökéletes megoldás, de minden negatívumra, amit felvet, rögtön válaszol is, néha kissé talán önmagát ismételve. Nem lehet elvetni elméletét abból a szempontból, hogy valóban kompromisszumos megoldást nyújthat egy átmeneti alkotmány vagy alkotmányos rendelkezés abban az esetben, ha az „alkotmányos szenvedélyek”253 túlságosan áthatják az adott ország társadalmát az alkotmányozás idején, és nem biztosított a stabilitáshoz vezető alkotmány elkészítéséhez szükséges idő vagy konszenzus. Hasonló szerepe lehet egy átmeneti alkotmánynak vagy alkotmányos rendelkezésnek abban az esetben, ha átmeneti társadalmi probléma kezelése szükséges. Erre példa az USA alkotmányának hatályba lépésekor elfogadott azon rendelkezés, mely szerint 1808-ig nem lehet döntést hozni a rabszolgaság eltörléséröl. ${ }^{254}$ Ha ebben a kérdésben az alkotmány elfogadásakor végleges döntést kellett volna hozni, könnyen lehet, hogy nem jött volna létre az USA. A halasztással sikerült kompromisszumot elfogadni, és 20 évvel elodázták a döntést. Ez az eset mutatja meg azt a veszélyt is, mely szerint a halasztás ahhoz is vezethet, hogy az adott társadalmi probléma tovább eszkalálódik, és még komolyabb következményekhez vezet; elég csak az amerikai polgárháborúra gondolni, melynek alapkonfliktusa pont ebben a kérdésben gyökerezett többek között. ${ }^{255}$

Az átmenetiség előny is lehet, amennyiben azzal segít a viták csillapításában, hogy a legérzékenyebb kérdések hosszú távú rendezését elhalasztja, amíg lehetőség nyílik például a közvélemény tájékoztatására vagy alapos kutatások elvégzésére. Emellett például, ha egy országban nincs kultúrája a demokratikus pluralizmusnak, mivel addig diktatórikus rendszer volt, nem tud az egész rendszer rögtön stabil demokráciaként müködni, elképzelhető, hogy szükség lesz olyan intézmények átmeneti müködésére, amelyek szükségtelenek, ha megszilárdult a demokratikus rendszer. ${ }^{256}$

Ez történt például Portugáliában, ahol az 1976-os alkotmány a korábbi állami berendezkedésre tekintettel biztosította a hadsereg számára a politikai döntésekben való

\footnotetext{
${ }^{252}$ VAROL 2014, 414. p.

${ }^{253}$ VAROL 2014, 440. p.

${ }^{254}$ VAROL 2014, 444-448. pp.

${ }^{255}$ VAROL 2014, 447. p.

${ }^{256}$ VAROL 2014, 433. p.
} 
részvételt, ám 6 évre megtiltotta az alkotmány módosítását. Miután eltelt ez az időszak, alkotmánymódosítással létrejött a hadsereg demokratikus civil kontrollja, a demokrácia azóta is fejlődik. ${ }^{257}$ Indiában ezzel szemben az átmenetinek szánt rendelkezés, amely szerint extrajudiciális büntetés lehetséges, ${ }^{258}$ sokkal tovább hatályban maradt, mint ahogy az kívánatos lett volna. ${ }^{259}$ Ha átmeneti alkotmányos rendelkezésként épült volna be az alkotmányba, akkor könnyebb lett volna hatásai alól mentesülni.

Tehát az átmeneti alkotmány törékeny megoldás az alkotmány stabilitásának biztosítására, de kiélezett politikai, társadalmi helyzetben a legkényesebb kérdések tekintetében hasznos lehet annak alkalmazása, ugyanis lehetővé teszi, hogy a társadalmat megosztó kérdésben a halasztás mellett döntve az alkotmány egésze elfogadásának ügyében egyet érthessenek.

Előnyös lett volna átmeneti alkotmányos rendelkezés használata a 2010-es kenyai alkotmány elfogadása során is, ahol az abortusz kérdése váltotta ki a legnagyobb vitákat. Míg az alkotmányba került szöveg szerint „Az abortusz nem engedélyezett, kivéve, ha képzett egészségügyi szakember véleménye szerint sürgösségi kezelésre van szükség, vagy az anya élete, egészsége kerül veszélybe, vagy bármely más írott jogszabály ezt lehetővé teszi.". ${ }^{260}$ Az átmeneti alkotmányos rendelkezés használata helyett tehát azt a módszert választotta az alkotmányozó, hogy a részleges szabályozás mellett nyitva hagyta az egyéb jogszabályi úton történő döntés lehetőségét. Ez a félmegoldás azonban olyan heves ellenérzéséket váltott ki a kenyai polgárok azon részében, akik az abortuszt semmilyen formában nem tartják elfogadhatónak, hogy maga az alkotmány elfogadása is veszélybe került. ${ }^{261} \mathrm{Ha}$ az alkotmány hallgatott volna a kérdésről, vagy konkrétan későbbre halasztja a döntést, esetleg meghatározza kötelező felülvizsgálatának időpontját, minden bizonnyal kisebb társadalmi ellenérzés alakult volna ki a polgárokban, akik döntöttek az alkotmány szövegéről, mivel népszavazás volt a kérdésröl. ${ }^{262}$

\footnotetext{
${ }^{257}$ VAROL, OZAN O.: The Democratic Coup d'E'tat. Harvard International Law Journal / Vol. 53, Number 2, Summer 2012. 333-339. pp.

${ }^{258}$ India Alkotmánya 22. cikk

${ }^{259}$ VAROL 2014, 430. p.

${ }^{260}$ Kenyai Alkotmány 2. rész, Jogok és alkotmányos szabadságok, 26. cikk 4.

261 DiXOn, Rosalind - Ginsburg, Tom: Deciding not to Decide: Deferral in Constitutional Design. Chicago, Public Law and Theory Working Paper No. 389. 659. p.

262 Gettleman, JefFreY: Kenyans Approve New Constitution, New York Times, 2010, augusztus 5. http://www.nytimes.com/2010/08/06/world/africa/06kenya.html?mcubz=3
} 
Ez az ügy mutatja, hogy milyen kevés kell ahhoz egy kiélezett helyzetben - ami a forradalmi alkotmányozás sajátjának tekinthető -, hogy akár a teljes alkotmányozás meghiúsuljon annak következtében, hogy egy kérdésben nem sikerült megegyezésre jutni az ellentétes oldalon állóknak, mivel ez olyan súlyúnak bizonyul, hogy veszélybe kerül az egész alkotmányozás.

Egy alkotmánymódosítás is vezethet ilyen következményekhez, például 2012-ben a gyermekvédelemhez kapcsolódó alkotmánymódosítás nagy vitákat váltott ki Írországban, mivel sokáig nem tudtak megegyezni a képviselők a rendelkezések pontos megfogalmazása ügyében. ${ }^{263}$

Venezuelában éppen az alkotmányozó nemzetgyűlés felállítása eredményezett polgárháborús helyzetet, mivel az elnök ellenzéke került többségbe a parlamentben, a törvényhozás kikerülésével igyekszik hatalmát tovább szilárdítani, ezért alkotmányozó nemzetgyülési választásokat írt ki 2017. július 30. napjára, a parlamenti ellenzék pedig erre reagálva népszavazást hirdetett a kérdésről 2017. július 16. napjára. ${ }^{264}$ Az ország egyre inkább polgárháborús helyzetbe süllyed. ${ }^{265}$

Ennek elkerüléséhez nyújthat segítséget az átmeneti alkotmányos rendelkezés, azonban nem minden esetben tekinthető jolly jokernek ez az eszköz, ugyanis nincs arra garancia, hogy az alkotmányozáskor félretett kérdések feletti viták nem fognak még inkább felerősödni, és ezáltal még súlyosabb következményekre vezetni. ${ }^{266} \mathrm{Az}$ ÁR esetében is, ha nem tettek volna bele annyi alkotmányos rendelkezést, müködhetett volna, azonban pont a nem átmeneti rendelkezések miatt került a viták és a vizsgálatok kereszttüzébe.

Álláspontom szerint hasznos lehet az átmeneti alkotmányos rendelkezés, ha az adott országban valóban forradalmi a hangulat vagy egy kardinális kérdésben megosztott a közvélemény. „Rendes” körülmények között inkább hátráltathatja a fejlődést. Főleg, ha a hatályon kívül helyezés időpontjának bekövetkeztekor sincs meg a szükséges egyetértés az új alkotmány elfogadásához. Nagyobb sikerre vezethet egy lassabb

263 THORTON, LIAM: The Children's Referendum: the Oireachtas Debates http://humanrights.ie/constitution-of-ireland/childrens-amendment-blog-carnival-the-oireachtas-debates/ O’MAHONY, CONOR: Having regard for our children http://www.irishexaminer.com/viewpoints/analysis/having-regard-for-our-children-208565.html $264 \mathrm{http} / / /$ index.hu/kulfold/2017/07/06/kilenc_oran_at_tartottak_blokad_alatt_a_venezuelai_parlamentet/ 265 DRAVECZKI-URY ÁDÁM: Venezuela: diktatúra vagy polgárháború? http://www.honvedelem.hu/cikk/64973, BOOTHROYD ROJAS, RACHAEL: Tentative Talks Begin Between Venezuelan Government and Opposition https://venezuelanalysis.com/news/13363

${ }^{266}$ DIXON - GINSBURG 2012. 668. p. 
alkotmányozási folyamat, amelynek eredményeként klasszikus alkotmányt fogadnak el, úgymond „szavatossági idő” nélkül.

\subsection{Alkotmányos kíméletlenség}

Az alkotmány stabilitása fontos szempont a politikát irányító csoportok számára, ugyanis saját helyzetüket is az határozza meg, hogy az alkotmány milyen keretek között állapítja meg a hatalomgyakorlás módját. A kialakult status quo-t megváltoztatni kockázatos lépés lehet mind a hatalmon levők, mind az ellenzékiek számára. Ha egy alkotmányt az adott szituációban csak úgy lehet parlamenti keretek között megváltoztatni, hogy a két oldal összefog, az általában igencsak megnehezíti a módosítási eljárást, ld. Belgium esetében pl. a szöveg megváltoztatásán kívül más módszer is rendelkezésre állhat: az addigi játékszabályok másként való értelmezése, kitágítása oly módon, mely megváltoztathatja a közhatalmi szervek mozgásteret, de magát a rendszert nem rombolja le. (Ehhez azonban - jó esetben - a parlamenti politikán és jogalkotáson kívül álló, vagy ún. alkotmányos politikát folytató olyan hatalmi ágak és aktorok aktivitása szükséges, amelyek az alkotmány elfogadásában per se nem vesznek részt, hanem annak kereteit képesek tágítani, saját tevékenységükön, pl. értelmezésen keresztül. Egy amerikai megközelítésben azonban a játéktér ennél szélesebb, és nem csak a parlamenti politikán felül álló szereplők tevékenysége értékelhető alkotmányos kíméletlenségként.) Ezt a megközelítést nevezte el alkotmányos kíméletlenségnek (constitutional hardball) ${ }^{267}$ Mark Tushnet, amely tulajdonképpen nem jelent mást, mint „,ahogy az alkotmányjogot megkülönböztetett jelentőséggel bíró alkotmányos átalakulási időszakokban alkalmazzák. ”. ${ }^{268}$ Ez nem azt jelenti, hogy csak ily módon lehet a szereplőknek viselkedni alkotmányos átalakulás idején, hiszen ez a fajta attitüd olyan magatartásra utal, mely a határokon belül marad, azonban oly módon alkalmazza a szabályokat, amelyre szokásjogi alapon addig még nem volt példa. Erre a legkiválóbb példa talán a New Deal-hez kapcsolódó események azon része, mikor Roosevelt elnök úgy vette rá a Legfelső Bíróságot, hogy elfogadja a változásokat, és döntéseivel ne hátráltassa a gazdasági programja végrehajtását, hogy bejelentette, felemeli a bírák létszámát. Erre volt lehetősége, az alkotmány nem zárta ki

${ }^{267}$ Ezt a kifejezést és más vonatkozó meghatározások elnevezését is a baseball szabályaitól kölcsönözte Tushnet, melyek szó szerinti alkalmazásától eltekintek a magyar szókincsbe való be nem ágyazódásuk miatt, és inkább a tartalmi fordítás szerinti elnevezést alkalmazok.

268 TuShNET, MARK V.: Constitutional Hardball. 37 J. Marshall L. Rev. 523-553 (2004) 532. p. 
a bírák létszámának növelését, azonban az alkotmány hallgatólagos közmegegyezés szerinti értelmezésének megfelelően erre nem volt lehetőség és mód politikai célok megvalósítás érdekében, valamint Roosevelt álláspontja szerint alkotmányos változás zajlott. $^{269}$

Ez sikeres példa volt, de mi is az oka az alkotmányos kíméletlenség alkalmazásának? Általában az, hogy az átalakulás során a politikai szereplők igyekeznek pozíciójukat bebiztosítani, az eddig hatalmon levő csoport korábban elért „eredményeit” kívánja megőrizni, míg az ellenzék saját jövendő helyzetváltozásában bízva játszik. Tehát a tétek magasak, mivel a cél a kontroll kiterjesztése. ${ }^{270}$

Tushnet szerint az alkotmányos kíméletlenség másik példájának tekinthető a Marbury v. Madison eset is, ugyanis magán viseli annak jellemzőit: addig nem volt példa a Legfelső Bíróság olyan döntésére, amely alkotmánnyal ellentétesnek minősített volna egy törvényt, de az alkotmány nem zárta ki a lehetőséget. Az addig szokásjogon alapuló közmegegyezés az alkotmány értelmezésének vonatkozásában ezt nem tette lehetővé; valamint alkotmányos átalakulás volt folyamatban, s ennek egyik eleme volt a döntés. ${ }^{271}$ A fenti példákból is látszik, hogy az alkotmányos kíméletlenség alkalmazása nem kockázatmentes. Ha egy uralkodó csoport az alkotmányos kíméletlenség alkalmazásával kibővíti saját hatalmát, mindig számítania kell arra, hogy előbb-utóbb kikerül az irányításból, és az általa megerősített pozíció másnak az előnyére válik. Ez hosszútávon ható kockázat, amely inkább olyan időszakban fejti ki hatását, amikor az eredeti játékosok már befejezték politikai pályájukat - például a New Deal rendszer az 1930-as évek közepétől az 1970-es évek közepéig érvényesült-- ${ }^{272}$

Az alkotmányos kíméletlenség amerikai példájával találkozhatunk Magyarországon, ha az Alaptörvény negyedik módosítását vizsgáljuk. A negyedik módosítás az Alkotmánybíróság 45/2012 (XII. 29.) határozatára válaszul született, és rendelkezéseinek hatására olyan események következtek be, amelyekre 2010 előtt még nem volt példa a magyar alkotmányos gyakorlatban: az Alkotmánybíróság által megsemmisített rendelkezések bekerültek az Alaptörvény szövegébe, tehát megváltoztak a játékszabályok. ${ }^{273}$ Ennek utóhatásai között említhető az ötödik alaptörvény-módosítás, valamint az alkotmányellenes alkotmánymódosítások

\footnotetext{
269 TUSHNET 2004, 544-545. pp.

270 TUSHNET 2004, 533. p.

271 TUSHNET 2004, 538-544. pp.

272 TUSHNET 2004, 552. p.

${ }^{273}$ A folyamatról részletesen lásd: SZAKÁLY 2013, 363-378. pp.
} 
kérdésének előtérbe kerülése a magyar alkotmányjog-tudomány szemében, azonban a kérdés részletes vizsgálata külön fejezet tárgya. Ez a magyar típusú alkotmányos kíméletlenség átrendezte az addigi gyakorlatot, amely szerint az Alkotmánybíróság döntéseit tiszteletben tartja az alkotmányozó, és elfogadja azok erga omnes hatályát. Bár a kérdés többé-kevésbe rendeződött az ötödik alaptörvény-módosítás hatására, maga a tény, hogy az alkotmányozó az Alkotmánybíróság által korábban alkotmányellenesnek ítélt jogszabályi rendelkezéseket ${ }^{274}$ emelt alkotmányos szintre, ezzel lehetőséget kínálva az alkotmányellenes alkotmánymódosítások diskurzusba emelésére, esetleges alkalmazására, nagy érdeklődést váltott ki az alkotmányjogászok körében. Azonban ezt a lehetőséget gyorsan kizárta a játékból az Alaptörvény, ${ }^{275}$ amellyel az alkotmányozó átalakította az addig kialakult (szokás)jogi rendszert.

Az alkotmányos stabilitást akkor erösítheti az alkotmányos kíméletlenség, hogyha magán az alkotmányos kereten nem változtat, de azon belül hoz újat, ami megváltoztatja az addigi képet, melynek köszönhetően valószínűleg tovább lesz hatályos az alkotmány, hiszen annak szövegszerü módosítása nélkül sikerült valamely kérdést újrafogalmazni. Másik oldalról komoly veszélyekkel jár, hiszen ha olyan szinten borítja fel a kialakult hatalmi rendszert, melynek hatására megbillen a jogállami egyensúly, és az egyik hatalmi szereplő túlhatalma jön létre, annak következményei károsak az egész alkotmányos rendszerre nézve, veszélybe kerülhet a demokrácia.

Az alkotmányos kíméletlenség megfelelően alkalmazva tehát hasznos eszköze lehet az alkotmány stabilitásának erősítésének, azonban kockázatos eszköz is, mivel használata könnyen átbillentheti a mérleget az alkotmány olyan értelmezése felé, amely akár a korábban meghatározott jogállami kereteken túl mutat.

\subsection{Alkotmányos kötöttség}

Ha abból a szempontból vizsgáljuk egy adott alkotmány stabilitását az ismert formailag merev és rugalmas elhatárolás mentén, hogy milyen nehéz azt megváltoztatni, akkor érdemes az egyes országok alkotmánymódosításra és új alkotmány elfogadására vonatkozó szabályait tanulmányozni (lásd 6. fejezet az EU tagállamok alkotmányai vonatkozásában). Azonban a gyakorlati vizsgálat mellett érdemes arra a szempontra is

\footnotetext{
${ }^{274}$ Melyek jogforrástani megítélése is külön kérdés, lásd 45/2012 (XII. 29.) AB határozat

${ }^{275}$ Az Alaptörvény negyedik módosításával, részletesen lásd GÁVA 2014, 34-43. pp.
} 
tekintettel lenni, hogy miért célszerü az alkotmány módosítását vagy új alkotmány elfogadását nehezíteni, ezáltal az alkotmányt stabilabbá tenni.

Ennek az önkorlátozásnak az okát kereste Jon Elster, aki az alkotmányozót Odüsszeuszhoz hasonlítja, aki magát az árbochoz kötöztette, hogy a szirének énekének ellenálljon. Társai fülüket viasszal tömték be, hogy ne hallják a dalt, így nem engedték el Odüsszeuszt, az hiába kérte. ${ }^{276}$ Elster ehhez hasonlítja az alkotmányozót, aki saját magának állít korlátokat az alkotmányozás során a jövőre nézve, hogy miképpen tudja módosítani az alkotmányt vagy új alkotmányt elfogadni. Ezzel az alkotmányozó saját, esetlegesen nem megfelelő döntéseit igyekszik megakadályozni. ${ }^{277}$ Ezt a fogalmat a továbbiakban alkotmányos kötöttség néven fogom említeni. Ahogy azt Friedrich A. Hayek megfogalmazza: érdemes korlátokat állítani a többséggel szemben arra az esetre, ha később elveszítjük a józanságot. ${ }^{278}$ Az alkotmányozóra ezt úgy vonatkoztathatjuk, ha az alkotmányozás forradalmi típusára gondolunk, amikor valamely rendkívüli esemény hatására „támad fel az alkotmányozó kedv”, és gyorsan kell elkészülnie az új alkotmányos dokumentumnak. Ebben az esetben veszélybe kerülhet a józanság, hiszen pont ilyenkor támadnak fel a viták, forradalmi helyzetek alakul(hat)nak ki. Háború, gazdasági összeomlás is lehet a kiváltó ok, tehát a valóságban olyan helyzetekben fogadnak el gyakran alkotmányokat, amelyeket Elster szerint leginkább el kellene kerülni, mert azokban hiányzik a józanság. ${ }^{279}$

Azonban a józan pillanatokban is akadhatnak olyan kérdések, melyek hosszú vitákat váltottak ki eddig is az adott rendszerben, és az alkotmánynak kellene megfelelően kezelnie azokat, ám az nem jár sikerrel. Tipikusan ilyen ún. ,állandó szenvedélyeknek” tekinthetőek a kisebbségi, nemzetiségi, vallási kérdések. Ezek a területek alapesetben is érzékenyek, az alkotmányba foglalásuk pedig különösen felkorbácsolhatja a szenvedélyeket. $^{280}$

„A probléma nemcsak az, hogy idöt kell adni a szenvedélyek lecsillapodására -bár esetenként ez is fontos lehet-, hanem az, hogy figyelembe vegyük az emberek általános alkalmatlanságát arra, hogy világosan megértsék egy bizonyos lépés minden lehetséges

\footnotetext{
${ }^{276}$ HOMrosz: Odüsszeia 12. ének http://mek.niif.hu/00400/00408/html/

277 ELSTER, JON: Ulysses Unbound: Studies in Rationality, Precommitment and Constraint., Cambridge University Press, 2000. 94. p.

${ }^{278}$ The Collected Works of F. A. Hayek Volume XVII. The Constitution of Liberty The Definitive Edition, HAMOWY, RONALD (szerk.): The University of Chicago Press, 2011. 268. p.

${ }^{279}$ ELSTER 2000, 159. p.

${ }^{280}$ ELSTER 2000, 157. p.
} 
következményét, valamint hajlamukat arra, hogy az elvek általánositásától függjenek azért, hogy sikerüljön egyéni döntéseket a közös döntésekbe beilleszteni. "281

Tipikusan akkor merül fel ún. alkotmányos pillanat, ${ }^{282}$ amikor az állampolgárok igénye az alkotmány elfogadására/módosítására olyan szinten eszkalálódik, hogy komoly társadalmi elvárásként jelenik meg a változás szükségessége, nyomás alá kerül az alkotmányozó. Ebben a helyzetben különösen nehéz a józan ész általános követelményeire hivatkozni, hiszen ezek a „szenvedélyek” teszik lehetővé az alkotmányozás/alkotmánymódosítás megvalósításához szükséges többséget az alkotmányozó oldaláról, és az elengedhetetlen figyelmet a társadalom részéről.

Ahogy azt Finn idézi John Potter Stockton egy 1871-es beszédéből: „Az alkotmányok láncok, melyekkel az emberek megkötözik magukat józan pillanataikban azért, hogy ne haljanak meg önkezüktöl egy örült pillanatban. "283 Ilyen eszköz lehet a különbözö, az alkotmány szövegének korlátozására vonatkozó szabályok mellett intézmény(ek) létrehozása alkotmányos szinten, mely(ek) korlátozzák a törvényhozó hatalom lépéseit. Elster szerint erre igazán szép példa a magyar Alkotmánybíróság létrehozatala 1990ben, ugyanis a testület képes volt korlátozni a törvényhozó hatalom esetleges túlterjeszkedéseit. ${ }^{284} \mathrm{Ez}$ a helyzet azóta változáson ment keresztül, hiszen az Alkotmánybíróság szerepének megváltozása mellett az ország alkotmányos berendezkedésének egészén eltolódás fedezhető fel az 1989-es állapotokhoz képest. A rendszerváltozást követően az alapjaiban megváltoztatott alkotmány nem volt képes minden jogállami kihívásnak megfelelni, ez indikálta az Alkotmánybíróság aktívabb fellépést, amit a testület meg is tett. ${ }^{285}$ Azonban a későbbiekben a testület csökkentett korábbi aktivizmusán, és a demokrácia megszilárdulásával párhuzamosan visszább lépett a jelentős konfliktusok bizonyos kérdéseinek megítélésében. A 2010-et követő események sorában több jelentős kérdésben is állást foglalt a testület, ${ }^{286}$ viszont az alkotmányozó részéről jelentkező alkotmányos kíméletlenség hatására csökkentette

\footnotetext{
${ }^{281}$ HAYEK 2011, 268. p.

${ }^{282}$ A fogalom részletes bemutatása a fejezet későbbi részében következik.

${ }^{283}$ FInN, JoHN E.: Constitutions in Crisis: Political Violence and the Rule of Law. Oxford University Press, 1991. 5. p.

${ }^{284}$ ELSTER 2000, 89. p.

${ }^{285}$ SÓLYOM 2001, 115-119. pp.

286 Például bírák nyugdíjkorhatára, hajléktalanokkal kapcsolatos kérdések, valamint maga az Átmeneti Rendelkezések és az Alaptörvény negyedik módosítása
} 
aktivizmusát a testület, és a hangsúly a jogvédelemre került az államszervezeti kérdések vizsgálata helyett. ${ }^{287}$

Kérdés, mennyire alkalmas az adott testület arra, hogy valóban visszaszorítsa az alkotmányozó/alkotmánymódosító hatalmat. Bizonyos szituációkban alkalmas lehet pl. az igazságszolgáltatás erre a feladatra, mint például az USA Legfelső Bírósága a Marbury v. Madison ügyben megteremtette saját hatáskörét arra, hogy megvizsgálja a jogszabályok alkotmányosságát, ezzel ellenőrzés alá vonva a törvényhozó hatalmat. ${ }^{288}$ Ezzel szemben más helyzetekben nincs meg a megfelelő súlya az adott szervezetnek ahhoz, hogy hatással legyen az események alakulására, mint ahogy a következő példákban is látható. Több afrikai ország Legfelső Bírósága is kimondta alkotmánymódosítás vizsgálata során, hogy az alkotmányozó/alkotmánymódosító bármilyen rendelkezést beemelhet az alkotmányba, azokat nem lehet megvizsgálni abból a szempontból, hogy alkotmányosak-e. ${ }^{289}$ Tehát nyíltan kimondták, hogy bármit be lehet emelni az alkotmányba, nincs korlát. Az alkotmányellenes alkotmánymódosítások kérdése ${ }^{290}$ már más témához vezet, azonban itt az alkotmányozó/alkotmánymódosító hatalommal szemben korlátok meghúzásának szempontjából emeltem ki a problémát.

$\mathrm{Az}$ alkotmányos kötöttség fontos kérdése, hogyha a szuverént tekintjük az alkotmányozónak, mennyire képes/hajlandó egy omnipotens szervezet korlátozni magát, visszatérve a homéroszi hasonlathoz, mivel kötik ki az árbochoz. Elster álláspontja szerint a kérdésre a válasz az ígéretek kötőereje. Úgy véli, hogy a szuverén által tett ígéretek megszeghetőek a szuverén által, mivel nincs, ami korlátozza -ha a klasszikus hobbes-i gondolat mentén haladunk-. Azonban a mindennapok realitása ezt nem teszi lehetővé, hiszen a nyilvánosság előtt tett ígéret megszegése azzal a következménnyel járhat, a szuverén elveszíti hatalmát, tehát ha egy kijelentést nyilvánosság elött megtett a szuverén, többé azt nem tudja visszavonni, az tovább halad a kijelölt úton. ${ }^{291}$

\footnotetext{
${ }^{287}$ Ezt az utat jelölte ki az alkotmányjogi panasz kiterjesztése és az actio popularis korlátozása is.

288 Marbury v Madison 5 U.S. 137 (1803)

289 RoZNAI, YANIV: Unconstitutional Constitutional Amendments-The Migration and Success of a Constitutional Idea. The American Journal of Comparative Law Vol. 61, No. 3 (Summer 2013 ) 708-711. pp.

${ }^{290}$ A teljesség igénye nélkül: BARAK 2002, 321-341. pp.; ALBERT 2009, 5-47. pp.; ROZNAI 2013, 657719. pp.

${ }^{291}$ ELSTER 2000, 148. p.
} 
Elster az alkotmányos stabilitás jelentőségét abban is felfedezni véli, hogy jobb egy gyenge alkotmány, mint az alkotmány hiánya. Ha egy alkotmány nem müködik megfelelően, de stabil, az még mindig elönyösebb véleménye szerint, mint az alkotmány hiánya, amely törékennyé teheti az egész rendszert. ${ }^{292}$

Egy alkotmány puszta léte sem mindig garancia annak betartatására, ha nincs meg mögötte a megfelelő kényszerítő erő. Akkor csupán papírra vetett gondolatok maradnak az alkotmányos rendelkezések, elég csak azokra a diktatúrákra gondolnunk, melyek rendelkeznek alkotmánnyal, hiszen az alkotmány létezése és az alkotmányosság nem szinonim kifejezések. ${ }^{293}$ Lehetnek magas szintű kinyilatkoztatások az alkotmányban, ha a valóság ettől teljesen eltérő képet mutat. Például Szíria alkotmányának 19. cikkében a következő olvasható: "Az Arab Szír Köztársaság társadalma a szolidaritás, a szimbiózis és a szociális igazságosság, szabadság, egyenlöség, valamint minden egyén emberi méltósága fejlesztésének elvi alapjain nyugszik."294 Érezhető az ellentmondás a jelenlegi háborús helyzet és az alkotmány szövegébe foglalt fennkölt nyilatkozat között. Számos példát lehet találni hasonló típusú rendelkezésekre, amelyek szemben állnak a valós helyzettel. ${ }^{295}$

A mérleg másik serpenyőjében vannak azok a helyzetek, amikor az segít az alkotmányos fejlődésnek, ha bizonyos rendelkezéseket, amelyeket nem lehet/tudnak megváltoztatni, félretesznek, vagy teljesen más értelmet adnak az eredeti szövegnek. Erre például szolgálhat az USA alkotmánya, ugyanis pl. a privacyre vonatkozó rendelkezések szó szerint nem találhatóak a szövegben, azonban több alkotmánykiegészítés bizonyos részeinek együttes értelmezésével a Legfelső Bíróság kiolvasztotta a magánszférához való jogot a szövegböl (pl. V. és XIV. alkotmánykiegészítés). ${ }^{296}$

A bírói értelmezés segítségével lehet stabil az alkotmány, ha nehezen módosítható, bár ez sem mindig vezet eredményre. Nemcsak az alkotmány félretétele, hanem annak nem megfelelő értelmezése is vezethet a stabilitás megingásához. Ahogy arra Jackson bíró

\footnotetext{
${ }^{292}$ Kivéve, ha van történeti alkotmánya az országnak, amely biztosítja a szükséges stabilitást az állam müködéséhez.

${ }^{293}$ SAMU 1997, 130. p.

${ }^{294}$ Szíria Alkotmánya

295 Számos fejlődő ország fogalmaz meg alkotmányában fennkölt célokat, melyek gyakorlati megvalósítása általában problematikus.

296 SZABÓ MÁTÉ DÁNIEL: Az alapjogok információs jogi rétege. Jogi tanulmányok, 2010/1, Ünnepi konferencia az ELTE megalakulásának 375. évfordulója alkalmából (2010. április 23.) I. kötet. 111-112. pp.
} 
felhívta a figyelmet a Terminiello v. City of Chicago döntéshez füzött különvéleményében: „Fennáll a veszélye annak, ha a Bíróság nem társít egy kis gyakorlatias bölcsességet a doktrinális logika mellé, akkor az alkotmányos alapjogi katalógust öngyilkos paktummá változtatja”. ${ }^{297}$ Tehát a bíróságnak saját, jól felfogott érdekében figyelnie kell arra, hogy az alkotmány értelmezése a józanság határain belül maradjon (vissza is kanyarodva ezzel megint Homéroszhoz): szükséges, hogy Odüsszeusz az árbochoz legyen kötözve arra az esetre, ha pillanatnyi örület venne rajta erőt. Ezt a szerepet látja el az európai országok nagy részében az Alkotmánybíróság, hogy az alkotmányosság őreként odafigyeljen arra, ne adódjon probléma a józanság hiánya miatt. ${ }^{298}$

Az előbb említett amerikai példában foglalt „alkotmányos öngyilkosság” megelőzésére bevezetett intézkedések nem biztos, hogy kielégítő eredményre vezetnek, ugyanis akár komolyabb problémák kiváltói is lehetnek, mint amelyek elkerülésére elfogadásra kerültek, mivel maga az alkotmány is folyamatos hatásoknak van kitéve, hiszen folyton változnak egy adott rendszert érő külső és belső hatások is. ${ }^{299}$

Az alkotmány stabilitása mindezek ellenére olyan szempont, amelynek biztosítása kiemelkedő jelentőségü. Részben egyetértek Elsterrel, az alkotmány stabilitásának kiemelkedő jelentősége van az egész közpolitikai rendszer stabilitásának, kiszámíthatóságának szempontjából. Ám nem tudom elfogadni a „gyenge alkotmány is jobb, mint a semmilyen alkotmány" elvét. Ugyanis véleményem szerint jobb, ha nincs alkotmány, és akár az addig szokásra, akár a történeti alkotmányra, akár az egyszerü törvényekre, akár az alkotmánybírósági/legfelső bírósági iránymutatásokra támaszkodva müködik az adott rendszer, mintha egy olyan alkotmány rendelkezéseit tartatnák be az állampolgárokkal, amely káros hatásokhoz vezet. Bár az alkotmány irányt mutathat, és egységesítő hatással is rendelkezik, ha azzal a társadalom képes azonosulni, azonban vannak olyan esetek, amikor jobb a társadalom számára, ha először kialakul a közpolitikai rend, majd ezt követi az alkotmányozás.

\footnotetext{
297 Terminiello v. City of Chicago

${ }^{298}$ AZ USA gyakorlatában pedig a 'judicial restraint', legegyszerübben a bírák önkorlátozása segít ennek kiküszöbölésében, a fogalom értelmezéséhez lásd: POSNER, RICHARD A.: The Meaning of Judicial SelfRestraint. Indiana Law Journal, Volume 59, Issue 1, Winter 1983, 10-18. pp.

${ }^{299}$ ELSTER 2000, 174. p.
} 


\subsection{Dinamikus stabilitás}

A stabilitás fontossága mellett azzal is érdemes foglalkozni, hogy ha sikerült azt megvalósítani, hogy egy ország alkotmánya időtálló legyen, akkor milyen mértékben váljon megváltoztathatatlanná úgy, hogy közben biztosítson mozgásteret a kisebb változásokhoz való alkalmazkodáshoz, ezáltal garantálva a minél hosszabb távú alkalmazhatóságot.

Erre a kérdésre igyekszik válasszal szolgálni a dinamikus stabilitás elmélete. David Gray azt a kérdést föleg a vallásra vonatkozó rendelkezések alkotmányba foglalásának mikéntjére vonatkoztatja, ${ }^{300}$ azonban álláspontom szerint gondolatmenetének elemei felhasználhatók az egész alkotmány stabilitására vonatkozóan is.

Gray szerint akkor stabil egy alkotmányos rendszer, ha bizonyos csoportok szemben állnak egymással, de nem egy konfliktus mentén, hanem számos különböző ok miatt. Úgy véli, minél „eröteljesebb a multiplicitás és a változatosság a szegmentált eltérö kapcsolatokban", ${ }^{301}$ annál nagyobb az esélye a stabilitás kialakulásának és fenntartásának. Azok a társadalmak, melyek képesek ezt a dinamizmust fenntartani, jobban tudnak reagálni mind a külső, mind a belső kihívásokra. Ezzel szemben egy olyan társadalomnak, mely egyetlen identitással rendelkezik, könnyen felborulhat a stabilitása, mivel nem elég rugalmas. Gray szerint egy ilyen társadalom „ijesztöen törékeny, instabil és a szakadék szélén táncol, egy kiváltó eseményre várva, mely elszabaditja az agressziv eröszakot és a káoszt." ${ }^{302}$ Ezt a gondolatmenetet tovább folytatva megállapítható, hogy Gray szerint az a társadalom, melyet nem a diverzitás jellemez, monolitikus, és így sokkal sérülékenyebb a változásokkal szemben, mint egy „edzettebb” társadalom. Erről eszünkbe juthat Szent István intelme is, mely szerint „(...) az egy nyelvü és egy szokású ország gyenge és esendö.”. ${ }^{303} \mathrm{Az}$ embereket megosztja többek között a faj, a vallás, a képzettség szintje, stb. Gray leírása alapján a társadalmat Venn-diagrammok összességeként lehet elképzelni, amelynek rendszerében minden ember a különböző irányultságok alapján, egyedileg helyezhető el. ${ }^{304}$

\footnotetext{
${ }^{300}$ GRAY, DAVID: Constitutional Faith and Dynamic Stability: Thoughts on Religion, Constitutions, and Transitions to Democracy. Maryland Law Review 69, no. 26 (2009) 26-38. pp.

301 GRAY 2009, 30. p.

302 GRAY 2009, 30. p.

303 Szent István király intelmei Imre herceghez, VI. A vendégek befogadásáról és gyámolitásáról, http://mek.oszk.hu/00200/00249/00249.htm

${ }^{304}$ GRAY 2009, 32. p.
} 
Ha egyetlen konfliktus felülemelkedik, és eluralkodik a többi felett, az már a homogén társadalom irányába mutat, amely komoly veszélyeket hordozhat magában, elég példának okáért a nemzetiszocialista rezsim kialakulására gondolni, ahol a konfliktusok élére az antiszemitizmust helyezték, vagy Ruanda 1994-ben kitört polgárháborújában a hutuk és a tuszik addig békés egymás mellett élése változott át mindent átható származási konfliktussá. ${ }^{305}$

Találhatunk a magyar alkotmánytörténetben is példát erre a kérdés vizsgálatakor. Amíg a társadalmat többféle konfliktus is uralja egyszerre, kisebb az esélye a radikalizálódásnak. A második világháború kitörése előtt nyilvánvalóvá vált, hogy melyik oldaltól számíthat Magyarország területi igényeinek támogatására, onnantól kezdve a társadalom nagy része abba az irányba indult, ahonnan a trianoni békeszerződés eredményeként elvesztett területek visszaszerzése volt várható, tekintet nélkül minden egyéb következményre, amelynek következtében a revizionista Magyarország a nemzetszocialista Németország szövetségese lett.

A magyar rendszerváltozás során számos érdekkonfliktus alakult ki, a választásokon induló pártok számából arra lehet következtetni, hogy az egymástól teljes mértékben eltérő érdekek megjelenése elnehezítette volna az alkotmányozást, ami éppen ezért parlamenti kereteken kívül is zajlott le..$^{306}$ Talán túl sok kis konfliktust lehetne azonosítani ezzel a szemlélettel ahhoz képest, ami „egészséges” egy alkotmányozás során, s éppen ebből kifolyólag is célszerü volt a kompromisszumos átfogó módosítás, mint a sok vita során elhúzódó parlamenti alkotmányozás.

A dinamikus stabilitás elmélete hasznos az elemzés számára abból a szempontból, hogy az alkotmány stabilitását nem magának az alkotmánynak a tartalma alapján vizsgálja, hanem a mögötte álló társadalom milyenségét veszi alapul. Ennek a gyakorlatias hozzáállásnak a jelentőségét abban vélem felfedezni, hogy fontos az alkotmány stabilitása szempontjából az, hogy milyen rendelkezések vonatkoznak annak módosítására, vagy új alkotmány elfogadására (lásd 6. fejezet). Közben nem lehet elfelejtkezni arról, hogy az adott ország társadalmi, gazdasági, politikai helyzete nagyban meghatározza az alkotmány betüjének gyakorlati érvényesülését, és ha olyan változások következnek be egy adott társadalomban, amelyet az alkotmány nem tud megfelelően kezelni, hiába a nehezen megváltoztatható alkotmányos dokumentum, a

\footnotetext{
${ }^{305}$ GRAY 2009, 34-35.

306 Lásd: SUlYoK MÁRTON - TRÓCsÁNYI LÁszló: Preambulum. In: JAKAB ANDRÁs (szerk.): Az Alkotmány kommentárja, I., Századvég Kiadó, Budapest, 2009. 87-89. pp.
} 
valóság miatt változni fog maga a közhatalmi rendszer, akár félretéve, akár elsöpörve az adott alkotmányt, a kialakított szabályok alkalmazása nélkül is.

Az érem másik oldalán a visszavont módosítások találhatóak. Elég csak arra gondolni, hogy az USA alkotmánytörténetében is találhatóak visszavont alkotmánymódosítások. Példának okáért a XVIII. alkotmánymódosítás, az alkoholtilalom ügyének esetében visszavonás történt 1933-ban a XXI. alkotmánymódosítással. ${ }^{307}$

\subsection{Alkotmányos pillanat}

Bruce Ackerman az 1980-as években kezdte el kidolgozni nagyhatású elméletét, amelynek keretében újraértelmezte az USA alkotmánytörténetét, új szempontból vizsgálva az eseményeket. Kiindulópontja szerint nem szükséges az alkotmány módosításához, hogy az V. cikk szerinti alkotmánymódosítási eljárás menjen végbe, mert az egyéb módon is megvalósulhat, például, ha egy alkotmányos pillanat jön létre. Bemutatja, hogy az USA történetének mely pillanatait tekinti alkotmányosnak. ${ }^{308}$ Három sikeres alkotmányos pillanatot talált: az amerikai polgárháború utáni alkotmánykiegészítések elfogadását, a $N e w$ Deal sikerét ${ }^{309}$ és a civiljogi mozgalmak eredményeként létrejött társadalmi változásokat. ${ }^{310}$

Véleménye szerint az USA egy dualista demokrácia, ahol a „,normál politika” és a „különleges jogalkotás” váltja egymást, ahol az utóbbi jóval ritkább. ${ }^{311}$ A ,különleges jogalkotás” lehetőségéhez szükséges, hogy magas szintű társadalmi mobilizáció jöjjön létre egy adott kérdés megvitatása során, az kilépjen a megszokott mederből, és olyan szintű érdeklődést váltson ki, amely nagyban meghaladja az átlagos állampolgárok politikai aktivitását. ${ }^{312}$ Továbbá az egyik hatalmi ág képviselőjének is a változás mellé kell állnia. ${ }^{313}$ Emellett választásoknak is be kell következnie, mely szintén megerősíti vagy visszaveti a kérdés eldöntését. ${ }^{314}$

\footnotetext{
${ }^{307}$ https://www.senate.gov/civics/constitution_item/constitution.htm\#amdt_14_(1868)

308 ACKerman 1993; ACKERMAN, BRUCE: We the People 2. Transformations. The Belknap Press of Harvard University Press, Cambridge, Massachusetts, London, England, 1998.; ACKERMAN, BRUCE: We the People 3. Civil Rights Revolution. The Belknap Press of Harvard University Press, Cambridge, Massachusetts, London, England, 2014.

ACKERMAN 1993, 44-57. pp.

310 ACKERMAN 1993, 35. p.

311 ACKERMAN 1993, 31-32. pp.

312 ACKERMAN 1993, 231-243. pp.

313 Például a New Deal esetében Roosevelt tett így.

${ }^{314}$ Rooseveltet támogatták a választók - a New Dealt is támogatták ezzel
} 
Felvázolja, hogy milyen lépései vannak ennek a folyamatnak (signaling, proposing, mobilised popular deliberation, legal codification). Ha első lépésként kialakult a megfelelően mozgósított támogatói réteg a társadalomban valamely kiemelt politikai szereplő hatására, és ez a kérdés kerül a viták középpontjába (signaling); a második lépés: az előterjesztés. A korábbi, a párbeszédben megjelent elvek itt jelennek meg szervezett formában, alkotmányos reform kifejezett céljával (proposing). Ezt követően elkezdődnek a mobilizált társadalmi tárgyalások, amelyek során a célokat tesztelik, (mobilised popular deliberation) ez eredményezhet erős ellenállást is, ekkor elbukik a folyamat. Ha továbbjut ezen a perióduson is, utolsó lépésben következik a kodifikáció, amelynek során a Legfelső Bíróság beépíti az alkotmányba az elérni kívánt rendelkezést a jogalkotás hatására, megfelelően magyarázva azokat (legal codification). ${ }^{315} \mathrm{Ez}$ nem mindig jár az alkotmány szövegének tényleges megváltoztatásával -kiegészítésével az USA esetében-. A New Deal érvényre jutása során nem volt alkotmányszövegkiegészítés, hanem a Legfelső Bíróság gyakorlatának módosulása elegendő volt a komoly alkotmányos változások kialakulásához. ${ }^{316,317}$

Ackerman elméletének lényegi pontja, hogy csak akkor lehet alkotmányos pillanat, ha az átlagostól eltérő érdeklődés, támogatás alakul ki egy kérdés mellett, ami kiemeli azt a napi politikai játszmák közül, három vonatkozásban is: mélység, szélesség és határozottság. ${ }^{318}$

Elmélete nagy hatást fejtett ki az alkotmányjogi gondolkodók között, több kritikusa és támogatója akad a mai napig világszerte. Az alkotmányos pillanat-elmélettel szemben kritikus Tushnet szerint az alkotmány elfogadása, és a későbbiekben elfogadottsága nem csak az adott pillanatban kimutatható társadalmi lelkesedétől függ, hanem attól is, hogy gyakorlati alkalmazása milyen módon valósul meg. ${ }^{319}$ Álláspontja szerint a polgárháború után természetes volt a változás, a New Deal esetében pedig kritikusan

\footnotetext{
315 ACKERMAN 1993, 266-267. pp.

316 ACKERMAN 1993, 268-269. pp.

317 Ezt más szerzők is kritikával illetik: MCCONNELL, MichAEL W: The Forgotten Constitutional Moment.. University of Minnesota Law School. Retrieved from the University of Minnesota Digital Conservancy,

(1994). https://conservancy.umn.edu/bitstream/handle/11299/167069/11_01_McConnell.pdf?sequence=1\&isAllo wed=y 118-119. pp.; LEVINSON, SANFORD: Accounting for Constitutional Change (or, how many times has the United States constitution been amended? (A) <26; (B) 26; (C) >26; (D) all of the above) in: LEVINSON, SANFORD (szerk.): Responding to Imperfection The Theory and Practice of Constitutional Amendment, Princeton University Press, 1995, 430. p.

318 ACKERMAN 1993, 272-277. pp.

319 Tushnet, MARK V.: Potentially Misleading Metaphors in Comparative Constitutionalism: Moments and Enthusias. Jean Monnet Working Paper 5/04. 7. p.
} 
tekint arra, hogy volt-e quasi alkotmánymódosítás. ${ }^{320}$ Emellett az elmélet által a „normál politika” és a „különleges jogalkotás” között kialakított elhatárolást is kritika alá vonja több szerző. ${ }^{321}$

További vagy más alkotmányos pillanatot is felfedezni vél az USA történelmében McConnell. Szerinte az 1876-os választások és azok következményei is alkotmányos pillanatnak minősülnek, ${ }^{322}$ amikor megváltozott a polgárháború után elfogadott alkotmánykiegészítések értelmezése, és visszaléptek a kijelölt útról az állampolgárok közti egyenlőség megvalósítása során, amelyet a polgárjogi mozgalom indított újra. Volt, aki az elmélet empirikus bizonyítottságát hiányolta. ${ }^{323}$

Támogatói is vannak elméletének. Empirikus kutatással bizonyították, hogy a XIV. alkotmánykiegészítés elfogadásakor valóban felfedezhető a felfokozott figyelem a társadalom részéről. Korabeli újságok algoritmikus elemzésével igazolta Daniel Taylor Young, hogy 1866-1868-as időszakhoz képest 1868 után jelentősen szükült az alkotmányos dialógus a korabeli újságokban, tehát a közéletben is megszűnt a felfokozott érdeklődés az alkotmányos kérdések iránt. ${ }^{324}$

Más támogatói szerint azért nagy jelentőségű az alkotmányos pillanatok elmélete, mert a gyakorlatban nem használt $V$. cikk szerinti alkotmánymódosítás helyett a gyakorlatban már megvalósult alternatívát kínál, ${ }^{325}$ és friss szemmel tekint az USA-beli alkotmánytörténetre. ${ }^{326}$

Ha a modern magyar jogtörténetet tekintjük át ilyen szemüveggel, a második világháború után lett volna talán lehetőség egy alkotmányos pillanatra, amikor egyértelművé vált az államforma változása. Kezdtek megfogalmazódni a különböző igények, azonban a kommunista hatalomátvétel más irányt adott az eseményeknek, és

\footnotetext{
320 Tushnet 2004. 2. p.; GerhardT, MichaEL J.: Ackermania: The Quest for a Common Law of Higher Lawmaking. William \& Mary Law Review, Volume 40. Issue 5. Article 7. 1747. p.

321 Tushnet, MARK V.: Living in a Constitutional Moment: Lopez and Constitutional Theory. Case Western Reserve Law Review Volume 46. Issue 3 1996. 852. p.; SANDALOW, TERRANCE: Abstract Democracy: A Review of Ackerman 's We the People. Const. Comment. 9, 1992. 324-325. p.

322 MCCONNELL 1994, 122-140. pp.

323 CHOUdhry, SuJIT: Ackerman's Higher Lawmaking in Comparative Constitutional Perspective: Constitutional Moments as Constitutional Failures? International Journal of Constitutional Law, Vol. 6, No. 2, (2008). 197. p.

324 TAYlor Young, DANIEL: How Do You Measure a Constitutional Moment? Using Algorithmic Topic Modeling To Evaluate Bruce Ackerman's Theory of Constitutional Change. 122 Yale Law Journal, 1990 (2013) 2024-2052. p.

${ }^{325}$ LEVINSON 1995, 430-431. p.

326 WINTER, STEVEN L.: Indeterminacy and Incommensurability in Constitutional Law. California Law Review Volume 78, Issue 6, Article 2, December 1990. 1515. p.; SimON, JonATHAN: Columbus in the Twilight Zone: Bruce Ackerman's Discovery of the Constitution. Berkeley Law, Berkeley Law Scholarship Repository, Faculty Scholarship, 1-1-1992. 502. p.
} 
nem tudott kialakulni az az önszervező folyamat, amely erre vezethetett volna. 1989ben is kezdett érvényesülni az alkotmányos dialógus. Tekinthetjük-e ezt alkotmányos pillanatnak?

Vizsgáljuk meg az Ackerman által felvázolt feltételeteket:

- megfelelően mozgósított támogatói réteg volt,

- aztán megjelent szervezett formában is az igény az alkotmány szövegének megváltoztatására. Elindultak a társadalmi tárgyalások, bár a demokratikus hagyományok hiánya miatt az EKA és NEKA tárgyalások vették át a fő szerepet, azonban a közvélemény élénk figyelemmel kísérte a folyamatot.

- Megtörtént a kodifikáció is, hiszen az alkotmány szövegének jelentős megváltoztatásával (a módosítások parlamenti megerösítését követően) új alkotmány jött létre, vagyis az egyik hatalmi ág a változás mellé állt. Az így létrejött új alkotmány megfelelt a demokratizmus és a jogállamiság követelményeinek, teljesen új irányvonalat jelölve ki hazánk számára, tehát

- gyökeresnek tekinthető a bekövetkezett változás.

Kérdéses, hogy össze lehet-e hasonlítani a kettőt, hiszen egy alkotmányos pillanat is gyökeres változásokat eredményez, míg a rendszerváltozás megítélése ebből a szempontból messze nem egyértelmű. Álláspontom szerint bár az alkotmány szövegének teljes körü változása miatt de facto tekinthetjük alkotmányozásnak a folyamatot, de iure olyan alkotmánymódosítás történt, amely megfelel az alkotmányos pillanat ackermani kritériumainak. Egy alkotmányos pillanat valósult meg Magyarországon 1989-1990-ben. Az amerikai analógia azonban nem teljességgel helytálló, mivel a társadalmi, gazdasági, politikai kontextus teljesen más, valamint az alkotmányt övező tisztelet (társadalmi tudat) mértéke is nagy mértékben eltérő, ${ }^{327}$ így teljesen más hatások érték a vizsgált folyamatokat itthon és az Egyesült Államokban. ${ }^{328}$ A rendszerváltozáskori magas társadalmi érdeklődés és részvétel viszont erôsíti a hasonlóságot.

\footnotetext{
327 TUSHNET 2004, 4. p.

${ }^{328}$ HALMAI GÁBOR: Alkotmányjog - Emberi jogok - Globalizáció - Az alkotmányos eszmék migrációja. L'Harmattan Kiadó, 2013. 71-82. p.
} 
Összegzésképpen látható, hogy az alkotmány stabilitására vonatkozó külföldi elméletek gyakorlati szempontú elemzéséhez találhatunk hazai példát, de legalábbis a vizsgált jelenség alapvonalaival számos párhuzam fedezhető fel. Ám minden összehasonlító alkotmányjogi vizsgálat során tekintettel kell lenni az egyes országok közti különbségekre. A VB az alkotmánymódosítás kérdését vizsgálva jelezte: „Nem lehetséges, és nem is kívánatos, hogy kialakitásra kerüljön az alkotmánymódositás absztrakt értelemben vett legjobb modellje. Az egyensúly a merevség és a rugalmasság között változó lehet országonként, a politikai és szociális helyzettöl, az alkotmányos kultúrától, az alkotmány korától, részletességétől és jellemzőitöl, valamint számos más tényezőtől is függ. "329 Tehát nem lehet úgy átvenni egy eszmét vagy modellt, hogy mellőzzük a két különböző ország alkotmányos rendszerének különböző tulajdonságait, viszont más ország sikeres vagy éppen sikertelen alkotmányjogi irányvonalai tanulságul szolgálhatnak akár alkotmányozás, akár alkotmánymódosítás, akár az alkotmány értelmezése során, különösen az alkotmányjog nemzetköziesedése idején. ${ }^{330}$

${ }^{329}$ CDL-AD(2010)001 22. p.

${ }^{330}$ HALMAI 2013, 23-29. p. 


\section{Az alkotmánymódosítási eljárás típusai az Európai Unió tagállamaiban}

\subsection{Az alkotmány stabilitása az eljárási eszközök szempontjából}

Ha egy országban az alkotmány megváltoztatása mellett döntenek, mindenképpen figyelembe kell venni az alkotmánymódosításra vonatkozó formális szabályokat, mivel minden alkotmánynak saját speciális szabályai vannak saját módosítására. ${ }^{331}$ Ezeket a szabályokat általában nem nehéz betartani, habár néha szinte lehetetlen megváltoztatni az alkotmányt. ${ }^{332}$

Számos tanulmány foglalkozott a stabilitás kérdésével és formáltak véleményt az ideális egyensúlyról. Egyetértek Rasch és Congleton azon állításával, mely szerint: „egy demokratikus alkotmány módositási eljárásának lehetövé kell tennie olyan reformokat, melyek széleskörü támogatással birnak, anélkül, hogy aláásnák gyakorlati jelentöségét a fennálló gyakorlatnak a többségi érdek megvalósitása érdekében, miközben védik a kisebbségi érdekeket is". ${ }^{333}$ Megoldást találni az adott helyzetre lehetséges, azonban reménytelen vállalkozás keresni egy általános szabályt a kérdésre, mely tökéletes megoldással szolgál minden esetre, mivel már az európai országok között jelentős eltérések lelhetőek fel. Mivel minden országnak megvan a saját egyedi alkotmánya, emiatt minden országban saját, speciális egyensúly alakult ki az alkotmányos változás merevsége és rugalmassága között. Ha egy alkotmány túl merev vagy túl rugalmas, az könnyen megbonthatja a társadalmi egyensúlyt is, azonban „a stabilitás ára a rugalmasság hiánya, és vice versa",,334 ennek okán minden állam igyekszik megtalálni az arany középutat.

Összegezve, nincs egyetlen tökéletes megoldás minden esetre, azonban néhány irányvonalat fel lehet fedezni. Ehhez az egyik lehetséges út megvizsgálni az

331 A fejezet az alábbi munkák átdolgozott és aktualizált változata: SZAKÁLY ZSUZSA: $A z$ alkotmánymódositási eljárás típusai az Európai Unió tagállamaiban. In. TóTH JUDIT (szerk.) Tanulmányok dr. Tóth Károly címzetes egyetemi tanár 70. születésnapjára, Szeged, 2015, 271-285. pp.; SZAKÁLY ZsUZSA: The Models of Constitutional Amendment in the Member States of the European Union. in: European Legal Studies and Research, International Conference of PhD Students in Law, 7th Edition, Timisoara, 2015. 557-567. pp.

332 Például az Egyesült Államok alkotmánya. Lásd: WILliams, JerRe S: Stability and Change in Constitutional Law, Vanderbilt Law Review, Vol. 17. 1963, 221-238. pp., Denning, B. P.: Means to Amend: Theories of Constitutional Change. Tennesse Law Review, Vol. 65. 1997. 155-244. pp.

${ }^{333}$ RASCH - CONGLETON 2006, 539. p.

${ }^{334}$ SKAGEN 2007, 85. p. 
alkotmányokat, mintákat és hasonlóságokat keresve, modelleket létrehozva az alkotmány elfogadásának és módosításának módjára vonatkozóan. ${ }^{335}$

\subsection{Módosítási modellek}

A tagállamok alkotmányainak módosításra vonatkozó vizsgálata során kialakítottam egy rendszert az alkotmánymódosítás modelljeire vonatkozóan, amelyben főleg az eljárási szempontok kerültek előtérbe. Számos tanulmány vizsgálta már az alkotmányos változás lehetséges módjait, különböző mintákat használva. Hasznát vettem nemcsak magyar, ${ }^{336}$ hanem külföldi kutatók munkájának is. ${ }^{337}$ Összegyüjtöttem, táblázatba foglaltam az Európai Unió tagállamainak alkotmánymódosításra vonatkozó szabályait lásd a 2. táblázat - és a következő eljárási típusokat különböztettem meg:

(i) többségi rendszer (az országgyülési képviselők többsége szavaz az alkotmánymódosításról);

(ii) kétkamarás rendszer (a parlament mindkét házának el kell fogadnia az alkotmánymódosítást);

(iii) kezdeményezés joga alapján történő megkülönböztetés (ki kezdeményezheti az alkotmánymódosítás a parlament előtt);

(iv) késleltetési eljárások (időbeli szünet az alkotmánymódosítási eljárás során);

(v) alkotmányozó nemzetgyülés (speciális testület az alkotmánymódosítási eljárásra);

(vi) moratórium (alkotmánymódosítási tilalom egy meghatározott időtartamra vonatkozóan);

(vii) népszavazás;

\footnotetext{
${ }_{335}$ Az alkotmányos változás határai már egy különálló kérdéskört alkotnak, lásd: GATMAYTAN, DANTE B.: Can Constitutionalism Constrain Constitutional Change? Northwestern Interdisciplinary Law Review, Vol. 3, Issue 1 (Spring 2010), 22-38 pp., Kelbley, Charles A.: Are There Limits to Constitutional Change? Rawl on Comprehensive Doctrines, Unconstitutional Amendments, and the Basis of Equality, Fordham Law Review, Vol. 72, 2004, 1487-1536. p., ROZNAI 2013, 657-720. pp., BARAK 2002, 321-341. pp.

${ }^{336}$ KILÉNYI GÉZA: Az alaptörvény stabilitását szolgáló garanciák a külföldi alkotmányokban és nálunk, Jogtudományi Közlöny, 1996. (Vol. 51.) No. 3, 110-124. pp., CHRONOWSKI NóRA - DrINÓCZI TíMEA ZELLER JUDIT: Túl az alkotmányon... Az alkotmányvédelem elméleti és európai kontextusa, továbbá magyar gyakorlata 2010-ben, avagy felülvizsgálható-e az alkotmánymódositó törvény az Alkotmánybiróság által Közjogi Szemle 2010/4. 1-12.pp.

337 LiJPhART, AREND: Patterns of Democracy Government Forms and Performance in Thirty-Six Countries, Yale University Press, 1999, Chapter 12: Constitutions Amendment Procedures and Judicial Review, 237. p.; ElSTER 2000, 101-104 p.; SKAGEN 2007, 80 p.; HolmeS - SUNSTEIN 1995, 293 p.; Tsebelis, George: Veto Players: How Political Institutions Work New York, Russel Sage Foundation and Princeton NJ: Princeton University Press, 2002. 302-322. pp.; BEZEMEK, CHRISTOPH: Constitutional Core(s): Amendments, Entrenchments, Eternities and Beyond Prolegomena to a Theory of Normative Volatility, The Journal Jurisprudence, 2011, Vol. 11, 527. p.
} 
(viii) egyéb (a többi kategóriába be nem helyezhető egyedi jellegzetesség).

Azt a fajta alkotmányos önkorlátozást, amely szerint az alkotmány bizonyos kiemelt részei csak alkotmányozással változtathatóak meg, alkotmánymódosítással nem lehetséges átírásuk, nem tekintem eme rendszer részének, mivel az ún. örökkévalósági klauzulák külön rendszert képeznek az elméleti rendszerben, vizsgálatukra is külön kerül sor (lásd 7. fejezet).

A legtöbb országban legalább kétféle eljárási eszköz használatos. A lényeges kérdés nem az, hogy elméletben mennyire szigorúak az alkotmánymódosításra vonatkozó szabályok, hanem az, hogy a gyakorlatban mennyire nehezítik meg az alkotmány módosítását. Egy olyan eljárást, amely egy államban egyszerüen lefolytatható, lehetséges, hogy egy másik ország esetében szinte megvalósíthatatlan, tekintettel az eltérő társadalmi, szociális és gazdasági háttérre. Minden ország rendelkezik speciális körülményekkel, ${ }^{338}$ amelyek kihatással vannak az ország alkotmánymódosítási eljárási szabályaira is, és így speciális eljárással is. ${ }^{339}$

\subsection{1 (Minösitett) többségi rendszer}

A többségi rendszer kiemelkedő jelentőségü a demokratikus rendszerekben. A legtöbb parlament, amely a közvetett képviselet elvén alapul, valamilyen típusú többségi rendszerrel müködik. Az általános törvények, amelyeket a parlament egyszerü többséggel szavaz meg, már elfogadásukban is eltérnek az alkotmánymódosítástól, mivel az alkotmánymódosítások elfogadása szinte mindig nagyobb fokú legitimációt igényel, emiatt széleskörü -általában kétharmados- többség szükséges elfogadásához.

Alapvetésként fontosnak tartom megjegyezni, hogy a többségi rendszer vizsgálatakor mindig figyelembe kell venni az adott ország választási rendszerét, és az ennek eredményei alapján kialakuló parlamenti erőviszonyokat, ugyanis ez határozza meg, hogy az adott országban milyen erős korlát a minősített többség, igényel-e politikai kompromisszumot, vagy egyetlen párt is reálisan meg tud valósítani alkotmánymódosítást. Ebben a vonatkozásban példaértékű önkorlátozásról tett tanúbizonyságot az 1994-ben kétharmados többséget szerzett kormánypárt

\footnotetext{
338 Például, speciális körülmények voltak Kelet-Európa új demokráciáiban 1989 után. Lásd: HoLMES SUNSTEIN 1995, 283. p.

${ }^{339}$ Az alkotmánymódosítás USA-ban használatos, speciális értelemben vett jelentését nem vizsgálom, mivel az nem illik bele az európai uniós tagállamok alkotmánymódosításra vonatkozó modelljei közé.
} 
Magyarországon, amikor 4/5-re emelték az alkotmányozáshoz szükséges többséget annak érdekében, hogy ne alakuljon ki egypárti alkotmányozás.

A fentiek alapján nem meglepő, hogy a huszonnyolc tagállam közül huszonnégy használja a többségi rendszer bizonyos fajtáit. A kivételek: Egyesült Királyság, Dánia, Írország és Svédország. Az Egyesült Királyság kivételes esete érthető speciális alkotmányos környezete miatt, azonban a másik három ország már más szempontból különleges.

Írországban nincs speciális többségi szabály az alkotmánymódosításra; minden egyes alkotmánymódosítást népszavazással kell elfogadtatni. ${ }^{340}$ Ebben az esetben egyszerübb elfogadtatni a Parlament (Oireachtas) két hazával az alkotmány módosítását, mint a legtöbb államban, viszont sokkal nehezebb az eljárást sikeresen befejezni. Dániában ${ }^{341}$ és Svédországban ${ }^{342}$ más módosítási eszközök is segítik az eljárás stabilitását.

A minősített többség klasszikusan kétharmada a választott képviselöknek, melyet tizenhárom tagállamban alkalmaznak. ${ }^{343} \mathrm{~A}$ kétharmados többséget négy tagállam használja más speciális többségi szabályokkal együtt. ${ }^{344}$ A huszonnyolc tagállam közül tizenhét tehát elfogadja a kétharmados többségi eljárást az alkotmány módosításához.

A háromötödös minősített többség az általános szabály Csehországban, Görögországban, Spanyolországban és Szlovákiában. Ez az egyik választható lehetőség az alkotmánymódosításra Észtországban és Franciaországban, ugyanis bizonyos országokban többféle különböző módszer közül lehet választani a módosítási eljárás során a konkrét esetnek megfelelően. Néhány országban a szükséges többségre vonatkozó szabályok megengedőbbek: például Olaszországban az abszolút többség is elengendő, ${ }^{345}$ azonban az elsőre rugalmasnak tűnő szabályozás valójában nagyon merev, ahogy az a későbbiekben vizsgált eljárási eszközök elemzésekor meg fog mutatkozni.

Néhány tagállam alkotmánya olyan, a többségre vonatkozó rendelkezéseket tartalmaz, melyek a kétharmados többségnél magasabb többséget követelnek meg az

\footnotetext{
340 Írország Alkotmánya 46. cikk (2)

341 A Dán Királyság Alkotmánya 88. cikk

${ }^{342}$ A Svéd Királyság Alkotmánya Nyolcadik fejezet 15-17. cikk

343 Ausztria, Belgium, Horvátország, Hollandia, Lettország, Litvánia, Luxemburg, Málta, Magyarország, Németország, Portugália, Románia és Szlovénia.

344 Bulgária, Ciprus, Finnország és Lengyelország.

${ }^{345}$ Az Olasz Köztársaság Alkotmánya 138. cikk (1)
} 
alkotmánymódosításhoz, de csak speciális esetekben (pl. sürgősség, az alkotmány elöszövegének elfogadásához szükséges többség.) $)^{346}$

Amíg a többség a leggyakrabban használt alkotmánymódosítási eszköz, szinte mindig kiegészítő eszközökkel együtt használják a módosítási eljárások során. A kivétel Szlovákia, ${ }^{347}$ ahol a többségi rendszer az egyetlen kötőeleme az alkotmánymódosítási eljárásnak. Az egyik kiegészítő eszköz a többségi rendszer mellett lehet annak meghatározása, hogy ki kezdeményezheti az alkotmánymódosítási eljárást. Ezt a módosítási eszközt használják a többségi rendszer mellett Horvátországban ${ }^{348}$ és Magyarországon. ${ }^{349}$ A parlament mindkét házának támogatása szükséges a többségi rendszer mellett Csehországban ${ }^{350}$ és Németországban. ${ }^{351}$ A többi tagállam ennél komplexebb alkotmánymódosítási eljárással rendelkezik, több, mint két módosítási eszközt használva. Azonban a többségi rendszer önmagában is lehet merev alkotmányos rendszer alapja, amennyiben a szükséges többséget nem tudják biztosítani a kormányon levő erők. ${ }^{352}$

\subsubsection{Népszavazás}

A legtöbb demokratikus országban -néhány fontos kivételtől eltekintve- ritkán használják ezt a módosítási eszközt, bár ez egy nagyon jelentős legitimációs lehetőség annak érdekében, hogy az állampolgárok megismerhessék az alkotmánymódosítás szövegét. Az államok gyakorlata ebben a kérdésben széles határok között mozog. Néhány ország minden fontos kérdés esetében alkalmazza a népszavazást, ${ }^{353}$ amíg más országok csak a legritkább esetekben. ${ }^{354}$

Ennek ellenére a második leggyakoribb módosítási eszköz a népszavazás. A huszonnyolc tagállam közül tizenöt használja valamilyen módon ezt a módosítási eszközt. ${ }^{355}$ A népszavazás Dániában, Írországban és Romániában kötelező eleme a módosítási eljárásnak. Itt is megtörténhet, hogy amennyiben egy nemzetközi

\footnotetext{
${ }^{346}$ Bulgária, Észtország és Finnország.

${ }^{347}$ A Szlovák Köztársaság Alkotmánya 84. cikk

${ }^{348}$ A Horvát Köztársaság Alkotmánya 147. cikk

${ }^{349}$ Magyarország Alaptörvénye (2011. április 25.) S. cikk (1)

${ }^{350}$ A Cseh Köztársaság Alkotmánya 39. cikk (4)

${ }^{351}$ A Németországi Szövetségi Köztársaság Alaptörvénye 79. cikk (2)

${ }^{352}$ Ahogy az Ausztria esetében megfigyelhető. Lásd: BEZEMEK 2011, 529-530. pp.

353 Például Svájc.

354 Pl. Németország esetében például csak egy kérdést lehet népszavazásra bocsátani: a tartományok területi beosztásának megváltoztatását. Németországi Szövetségi Köztársaság Alaptörvénye: 29. cikk

355 Ausztria, Dánia, Észtország, Írország, Lengyelország, Lettország, Litvánia, Luxemburg, Olaszország, Románia, Spanyolország, Svédország és Szlovénia.
} 
egyezmény elfogadása népszavazások múlik, végül egy nemzetközi standard vagy kötelezettség -mely kötelező erővel képezi részét a belső jognak - szenvedi meg a következményeket. (Elég csak a Lisszaboni Szerződésről tartott ír népszavazás 2008-as esetére gondolni.) $)^{356}$

Nem ez volt az első, és valószínüleg nem is az utolsó alkalom, amikor egy népszavazás megnehezítette egy alkotmánymódosítás elfogadását. Ez általánosságban könnyen okozhat merevséget az alkotmányos rendszerben, ha az alkotmány módosítására vonatkozó eljárás lefolytatása nem valósítható meg az alkotmányt módosítani kívánó politikai elit szándéka ellenére. Az alkotmánymódosítás speciális esetére vonatkoztatva a kijelentést, egyetérthetünk Lipjharrtal, aki szerint „ez lehetővé teszi az elégedetlen kisebbség számára, hogy kampányt indithasson a bejelentett módositás ellen", 357 amelynek eredményeként akár egy fontos és szükséges alkotmánymódosítás maradhat el, ha elegendő támogatást tudnak szerezni.

Az összes többi tagállam csak speciális eljárásként tekint a népszavazásra, amelyet csak különleges esetben lehet igénybe venni. Például, a spanyol alkotmány szerint a Parlament (Cortes Generales) által elfogadott alkotmánymódosítást akkor kell népszavazásra bocsátani, ha mindkét ház képviselőinek egytizede kezdeményezi ezt meghatározott időn belül. ${ }^{358}$

Másik példa Luxemburg, ahol az alkotmánymódosítás első körben elfogadása után szükséges egy második kör vagy egy népszavazás kiírása, amennyiben erre van igény. Ezt kezdeményezheti a „Képviselöház tagjainak több mint egynegyede vagy huszonötezer, a törvényhozói választások választói névjegyzékén szereplö választópolgár". ${ }^{359}$ A népszavazási eljárás speciális esete emellett még megtalálható a következő alkotmányokban: Ausztria, Észtország, Franciaország, Lengyelország, Lettország, Litvánia, Olaszország, Svédország és Szlovénia.

Franciaországban éppen vitás kérdésnek minősül az alkotmány népszavazás útján történő módosítása, ugyanis, arra az esetre, ha a Szenátus nem támogatná átfogó alkotmánymódosítási csomagját, a köztársasági elnök népszavazásos alkotmánymódosítást helyezett kilátásba. 2018 nyarát jelölte meg végső határidőnek a

\footnotetext{
${ }^{356}$ http://www.theguardian.com/world/2008/jun/13/ireland

${ }^{357}$ LIJPHART 1999, 231. p.

358 Spanyolország Alkotmánya 168. cikk (3)

${ }^{359}$ Luxemburg Nagyhercegség Alkotmánya 114. cikk
} 
kompromisszum kialakítására. ${ }^{360}$ Az átfogó reform például egyharmaddal csökkentené a parlamenti képviselők létszámát, és arányosabbá tenné a választási rendszert. ${ }^{361} \mathrm{~A}$ francia Alkotmánytanács is szerephez juthat az ügyben, amely az alkotmányos szervek egymással való viszonyára is kihatással lehet. ${ }^{362}$

A népszavazási eljárás igénybevételének szükségessége nehezítést jelenthet az alkotmánymódosítási eljárás során, ${ }^{363}$ amennyiben a társadalom mélyen megosztott az érintett kérdésben. Kompromisszum eléréséhez hónapokra vagy évekre is szükség lehet politikai berkekben, miközben az adott módosítás elengedhetetlen volna az ország fejlődéséhez, vagy előfeltétele egy nemzetközi szervezethez való csatlakozásnak.

\subsubsection{A kétkamarás rendszer szerepe}

Nem minden EU tagállamnak van kétkamarás parlamentje, bár a kétkamarás parlamenttel rendelkező országok száma meghaladja az osztatlan parlamenttel rendelkezőkét. A második kamara léte köthető az adott állam történelmi hátteréhez, néha az ország mérete is lehet a kiváltó oka, hogy az érintett politikai erők közötti megegyezés eredményének köszönhető.

Az alkotmánymódosítási eljárás során a második kamara szerepe kiemelkedő lehet, mivel képes lassítani vagy akár ellehetetleníteni az egész eljárást. Az időtartam kulcskérdése az alkotmánymódosításnak. A második kamara részvétele az eljárásban nélkülözhetetlen tizenegy tagállamban. ${ }^{364} \mathrm{Az}$ egyetlen olyan tagállam, mely két parlamenti kamarával rendelkezik, és a második kamarának nincs döntési jogköre az alkotmány módosítása során, Szlovénia.

A szlovén parlament két kamarája a Nemzetgyülés és az Államtanács. Míg a Nemzetgyülés dönt az alkotmány módosításáról, az Államtanács erre nem jogosult, ezáltal ez az egyetlen olyan második kamara a tagállamok közül, amelynek nincs

\footnotetext{
${ }^{360}$ Réforme de la Constitution : le spectre du référendum https://www.publicsenat.fr/article/politique/reforme-de-la-constitution-le-spectre-du-referendum-81858

361 GALTIER, LUDOVIC: Réforme constitutionnelle : les 5 mesures phares prévues par Macron http://www.rtl.fr/actu/politique/reforme-constitutionnelle-les-5-mesures-phares-prevues-par-macron7790235836

362 GALIERO, EMMANUEL: Révision constitutionnelle par référendum: les éclairages d'un constitutionnaliste http://www.lefigaro.fr/politique/le-scan/2018/01/29/25001-20180129ARTFIG00265-revisionconstitutionnelle-par-referendum-les-eclairages-d-un-constitutionnaliste.php ${ }^{363}$ LUTZ 1995a, 254, 264. pp.

364 Ausztria, Belgium, Csehország, Franciaország, Görögország, Hollandia, Írország, Lengyelország, Litvánia, Németország, Olaszország, Románia és Spanyolország.
} 
beleszólási joga az alkotmány módosításába. ${ }^{365}$ Az Államtanács szerepe 2013-ban változott meg. Ezt megelőzően joga volt bármely kérdésben népszavazást elrendelni, nem volt tiltott tárgykör. Az akkori szabályok szerint az Államtanácsnak alkotmánymódosítás esetén is joga volt népszavazást elrendelni. A szlovén alkotmány módosításakor 2013-ban az Államtanács elvesztette ezt a jogkörét, jelenleg speciális szabályok vonatkoznak a tiltott tárgykörökre. ${ }^{366}$

A kétkamarás rendszerben több idő jut a megfontolásra, ami hangsúlyozza az alkotmánymódosítás fontosságát, és „annál nagyobb a választópolgárok általi támogatása az alkotmányos reformnak, minél eltérőbb a két kamara összetétele”, ${ }^{67}$ ezáltal nagyobb legitimációt biztosítva az alkotmánynak.

\subsubsection{Kezdeményezési jog alapján történö megkülönböztetés}

Az alkotmány módosítása mindig az adott ország valamilyen jelentős politikai, társadalmi vagy gazdasági kérdéséhez kötött. Az alkotmány módosításának szükségessége több forrásból is eredhet, azonban a vox populi nem mindig vox dei, ahogy azt az emberiség a történelem viharai során megtanulhatta. Talán ez az oka, hogy minden tagállamban korlátozott azoknak a köre, akik az alkotmánymódosítást kezdeményezhetik.

Amíg elméletben minden tagállam parlamenti képviselőinek jogában áll alkotmánymódosítást kezdeményezni -kivéve meghatározott esetekben-, néhány ország ezt a jogot más közhatalmi szerveknek, vagy akár az állampolgárok bizonyos csoportjának is megadja. A tagállamok közül tizenhárom adott ilyen jogkört bizonyos állami szereplőknek. ${ }^{368}$ Néhány alkotmány meghatározta, hogy a parlament tagjainak önálló kezdeményezése nem elég, csak bizonyos számot elérő parlamenti képviselő kezdeményezhet alkotmánymódosítást. Ez a szabály Bulgáriában, Észtországban, Görögországban, Horvátországban, Lengyelországban, Litvániában, Romániában és Szlovéniában. Néhány országban a köztársasági elnök is kezdeményezhet

\footnotetext{
365 A Szlovén Köztársaság Alkotmánya 97. cikk ,,(1) Az Államtanács: a) törvényeket kezdeményezhet a Nemzetgyülésnél; b) véleményt nyilvánithat a Nemzetgyülés hatáskörébe tartozó ügyekröl; c) kérheti, hogy a Nemzetgyülés a törvény kihirdetése elött erröl ismételten döntést hozzon; d) vizsgálatot kérhet közérdekü ügyben a 93. cikk alapján. (2) A Nemzetgyülés kérésére az Államtanács köteles véleményt nyilvánitani egyes ügyekben. Amikor a Nemzetgyülés kéri, az Államtanács köteles vélemény nyilvánítani egyes ügyekben."

${ }^{366}$ A Szlovén Köztársaság Alkotmánya 90. cikk

${ }^{367}$ RASCH - CONGLETON 2006, 544. p.

368 Bulgária, Észtország, Franciaország, Horvátország, Lengyelország, Lettország, Litvánia, Magyarország, Portugália, Románia, Spanyolország és Szlovénia.
} 
alkotmánymódosítást: Bulgária, Észtország, Franciaország (a miniszterelnök javaslatára), Horvátország, Lengyelország, Magyarország és Románia esetében. Másik mód, ha meghatározott számú választópolgárnak áll jogában kezdeményezni a módosítást. Ez a lehetőség szerepel Litvánia, Románia, Spanyolország és Szlovénia alkotmányában. Néhány alkotmány megadja ezt a jogot a kormánynak is: Horvátország, Magyarország, Románia és Szlovénia. Magyarországon a parlamenti bizottságoknak is jogában áll alkotmánymódosítást kezdeményezni. ${ }^{369}$

A román alkotmány speciális eljárást határoz meg a kezdeményezésre: „Az Alkotmány módositását kezdeményezheti Románia Elnöke a kormány javaslatára, a képviselök vagy a szenátorok legalább egynegyede, valamint legalább 500000 szavazati joggal rendelkezö állampolgár. "370

Ha például a kezdeményezés a köztársasági elnöktől származik, minden bizonnyal több figyelmet fog kapni, mint egy általános törvénymódosítási javaslat, amelyet egy országgyűlési képviselő kezdeményezett. Az eljárás nyilvánossága kiemelkedő jelentőségű annak elfogadottsága miatt. A módosítási eljárás legelső lépésétől szükséges, hogy az nyilvános legyen, mivel az növeli a legitimációt, ami elengedhetetlen az alkotmányos stabilitás fenntartásához.

\subsubsection{Késleltetési eljárások}

Az adott politikai erőviszonyok vagy társadalmi-gazdasági konfliktusok kezelése miatt az időnek kiemelkedő jelentősége van az alkotmány elfogadása vagy módosítása során. ${ }^{371} \mathrm{Az}$ alkotmánymódosítás kezdeményezőinek minden lehetséges okot és következményt figyelembe kell venni annak érdekében, hogy minél szélesebb körben elfogadott megoldást találjanak. A hosszabb időtartam elviekben alkalmas arra, hogy növelje az eljárás legitimációját.

Tizenhárom tagállam alkotmánya tartalmaz valamilyen időmúlásra vonatkozó rendelkezést az alkotmánymódosítási eljárással kapcsolatban. Két késleltetési eljárás között tettem különbséget: (i) többszöri vita vagy (ii) több parlamenti ciklus (nemcsak az idő, hanem a politikai viszonyok változása is jelentős faktor) szükséges a módosítás elfogadásához. Mindkét eljárás lehetővé teszi, hogy a módosítást bizonyos idő eltelte után fogadhassák csak el, ennek segítségével pedig valamilyen szinten el lehet

\footnotetext{
${ }^{369}$ Magyarország Alaptörvénye (2011. április 25.) S) cikk

${ }^{370}$ Románia Alkotmánya 150. cikk

${ }^{371}$ BLOUNT - ELKINS - GINSBURG 2012, 41. p.
} 
határolódni a politikai és jogi kérdésektől, amelyek a módosítás során felvetődtek, és a társadalomnak, valamint a politikusoknak is lehetősége nyílik objektívebben vizsgálni a kérdést.

A többszöri vita szerepel Bulgária, Észtország, Lengyelország, Litvánia, Luxemburg és Olaszország alkotmányában. Bulgáriában „A Nemzetgyülés az ezirányú javaslatot annak beérkezésétöl számitott legkorábban egy hónap és legkésöbb három hónap leteltével tárgyalja meg.", ${ }^{372}$ és három sikeres szavazás szükséges három különböző napon. Észtországban három olvasat szükséges a parlament előtt „, az első és a második olvasat között legalább három hónap, a második olvasat és a harmadik olvasat között legalább egy hónap telik el. " ${ }^{373}$ Litvániában két olvasat és szavazás szükséges, egyhárom hónapos időintervallumokkal. ${ }^{374}$

A késleltetési eljárás másik típusa a közbeékelődő országgyülési választás (ahogy azt a VB fogalmazta meg). ${ }^{375} \mathrm{Ez}$ az eljárás használatos Belgiumban, Dániában, Észtországban, Finnországban, Görögországban, Hollandiában és Svédországban. Két altípusra lehet osztani: (i) ha az alkotmánymódosítás pontos szövegéről szavaz két parlament vagy (ii) az első parlament csak a módosítás alapelveiről szavaz.

A két parlament általi elfogadás sohasem egyszerü, az alkotmány merevségéhez vezethet ez az eljárási eszköz, bár a két altípus között jelentős különbség lehet. Egyszerübb az alkotmány módosítása, ha első körben csak a módosítás alapelveit kell meghatározni, nem pedig a konkrét szöveget. Azonban Dániában, Észtországban, Finnországban és Svédországban a módosítás pontos szövegét kell két parlamentnek elfogadnia bármilyen változás nélkül.

Kivételt képez Spanyolország, ahol nem főszabály parlamenti választások közbeékelése, hanem csak abban az esetben kerülhet rá sor, ha az alkotmány bizonyos rendelkezéseit kívánják módosítani. ${ }^{376}$

Ez a késleltetési mechanizmus nemcsak az állampolgároknak, hanem a parlament tagjainak is lehetőséget biztosít arra, hogy alaposan megfontolják a módosítást. Amíg az állampolgárok megismerkedhetnek a politikai pártok álláspontjával, addig a pártoknak

\footnotetext{
372 A Bolgár Köztársaság Alkotmánya 154. cikk

${ }^{373}$ Az Észt Köztársaság Alkotmánya 163. cikk

${ }^{374}$ A Litván Köztársaság Alkotmánya 148. cikk

${ }^{375}$ CDL-AD(2010)001, 42. p.

376 Spanyolország alkotmánya 168.cikk. „,(1) Az Alkotmány teljes körü módosítására irányuló javaslat, illetve a bevezetö cím, a II. fejezet, az 1. cím 1. szakasza, vagy a II. cím módositására vonatkozó javaslat elfogadása mindkét Kamara részéröl kétharmados többséget igényel és a Parlament azonnali feloszlatását vonja maga után."
} 
is van idejük részletesen átgondolni a döntésük következményeit. Ez az eljárás erös védelmezője lehet az alkotmány eredeti szövegének, mivel minden alkotmánymódosítást kezdeményezőnek számolnia kell azzal a veszéllyel, hogy az alkotmánymódosítási eljárás közepén tartott parlamenti választás befolyásuk csökkenéséhez vezethet, amelynek eredményeként akár az alkotmánymódosítási eljárás is kudarcba fulladhat, ami adott esetben káros hatással lehet az egész alkotmányos rendszerre.

\subsubsection{Móratórium}

A moratóriummal az alkotmányozók célja, hogy megakadályozzák a túl gyakori alkotmánymódosításokat, amelyek csökkenthetik az alkotmány erejét, valamint a tiszteletét is. Ez az eszköz lehetővé teszi a megfelelő felkészülést a résztvevők számára.

A moratórium négy tagállamban használt: Észtország, Görögország, Litvánia, Luxemburg és Portugália. Ezek az országok kizárják az alkotmány túl gyakori módosításának lehetőségét. A moratórium időtartama egy év Észtországban és Litvániában, öt év Görögországban és Portugáliában. Azonban ezt elkerülendő, a portugál alkotmány rendelkezése szerint a parlament négyötödös többséggel határozhat úgy, hogy bármikor módosíthatja az alkotmányt. ${ }^{377}$

Észtországban nem minden kérdésre terjed ki a moratórium, csak a tárgyalt témára, akár elfogadásra került az alkotmánymódosítás, akár nem. ${ }^{378}$ Ezzel szemben Litvániában csak a sikertelen alkotmánymódosításra vonatkozik az egy éves moratórium. ${ }^{379}$ Luxemburgban sem általános a moratórium, csak speciális esetben és kérdésekre vonatkozóan áll be. ${ }^{380}$

Ha az alkotmányt akár havonta megváltoztatják, nem képes betölteni feladatát: szilárd alapot biztosítani az állam müködésének. Hogy lehetne stabil egy kormányzati rendszer, ha alapját folyton változtatják? A túl szigorú szabályok az adott rendszer fejlődése ellen hathatnak, ám a túl extrém megoldások mindig fenyegetik a hatalommegosztás és a jogállam elvének érvényesülését a jogrendszerben.

\footnotetext{
377 A Portugál Köztársaság Alkotmánya 248. cikk

378 Az Észt Köztársaság Alkotmánya 168. cikk Ugyanabban a kérdésben nem terjeszthető elő alkotmánymódosítás a népszavazás vagy a Parlament által elutasított javaslattól számított egy éven belül. ${ }^{379}$ A Litván Köztársaság Alkotmánya 148 (2)

${ }^{380}$ Luxemburg Nagyhercegség Alkotmánya 115. cikk (1998. január 12-i alkotmánymódosítás.)

Régensség időszakában az Alkotmány a Nagyherceg alkotmányos jogosítványait, jogállását és öröklési szabályait érintő rendelkezései nem módosíthatók.
} 
Ha az alkotmány módosításának lehetősége is kizárt legalább egy éves időtartamra, az alkotmánymódosítás kezdeményezői kétszer is meggondolják az eljárás megindítását, és ez a tudatosság elengedhetetlen egy olyan eljárás során, mint az alkotmány módosítása. A moratórium jó eszköze annak, hogy több megfontoltságot és türelmet legyenek kénytelenek tanúsítani az alkotmány módosításának kezdeményezői. Ám azt is figyelembe kell venni, hogyha valamilyen alapvető politikai, társadalmi vagy gazdasági változás történik a moratórium ideje alatt, amelyre az alkotmánynak reagálnia kellene, akkor ezek a szükséges módosítások hosszú ideig nem történhetnek meg a moratórium miatt.

\subsubsection{Az alkotmányozó nemzetgyülés modellje}

Új alkotmány elfogadása az alkotmányozó hatalomhoz kötődik, valamint általában valamilyen kiemelkedő pillanathoz az adott ország történelmében, mint például egy forradalom kitörése vagy egy új hatalmi berendezkedés kezdete. Az alkotmány módosítása is kapcsolódhat fontos alkotmányos pillanathoz (például az EU-hoz való csatlakozás vagy az azonos nemüek házasságát lehetővé tevő szabályozás).

Amíg a múltban elég népszerü volt az alkotmányozó nemzetgyülés használata, manapság ez a legkevésbé elterjedt eszköz a tagállamok alkotmányaiban. Nincs olyan tagállami alkotmány, ahol az alkotmányozó nemzetgyülés kötelező volna alkotmánymódosítás elfogadásához. Alkotmányozó nemzetgyűlés tartásának lehetősége megtalálható Bulgária és Spanyolország alkotmányában.

Bulgáriában a Nemzetgyülés funkcionál parlamentként, elfogadhatja az alkotmány módosításait néhány kivétellel. A tiltott tárgykörökben való alkotmánymódosítás és egy teljesen új alkotmány elfogadása -egyebek mellett-a Nagy Nemzetgyülés hatáskörébe tartozik. ${ }^{381}$ Spanyolországban, ha nem fogadja el mindkét parlamenti ház háromötödös többsége az alkotmány módosítását, egy paritásos bizottságot hoznak létre alkotmány

\footnotetext{
${ }^{381}$ Bulgária Alkotmánya 158. cikk „A Nagy Nemzetgyülés:

1. új Alkotmányt fogad el;

2. dönt a Bolgár Köztársaság területének módositásáról és ratifikálja az ilyen módositást elöirányzó nemzetközi szerzödéseket;

3. dönt az államfelépités és az államigazgatás formájának megváltoztatásáról;

4. dönt az Alkotmány 5. cikke (2) és (4) bekezdésének, valamint az 57. cikke (1) és (3) bekezdésének megváltoztatásáról;

5. dönt az Alkotmány kilencedik fejezetének módositásáról és kiegészitéséröl."
} 
szövegének kidolgozására. Célját tekintve ez minősülhet alkotmányozó nemzetgyülésnek. ${ }^{382}$

Nem lehet eltekinteni attól, hogy ezek a testületek nem szükséges elemei az alkotmány módosításának, csak speciális esetekben. Régen sokkal komolyabb jelentősége volt, napjainkban már minimális szerepe van az alkotmányozó nemzetgyülésnek. Ez talán a bizalom kérdésére vezethető vissza. Az állampolgárok megbíznak a parlament tagjaiban, akiket ők választottak érdekeik képviseletére, de nincs kapcsolatuk egy olyan testülettel, amelynek tagjait nem ők választották meg. A legelterjedtebb módosítási eszközök a többségi rendszer és a népszavazás. Mindkettő kötődik a népszuverenitás elméletéhez, amíg az alkotmányozó nemzetgyülés tagjait nem mindig az állampolgárok választják meg.

Azonban a vizsgált esetekben az alkotmányozó nemzetgyülések kapcsolatban vannak a parlamenttel. Bulgáriában ugyanolyan módon választják tagjait, mint a parlamenti képviselőket, Spanyolországban pedig a Közös Bizottság mindkét ház tagjai közül választott képviselőkből áll. Bár manapság nem divatos az alkotmányozó nemzetgyülés intézményének használata, a jövőben még lehet reneszánsza ennek az eszköznek, ha kívánatosabbá válik egy olyan független testület szerepe az alkotmány elfogadása és módosítása során, mely nem kapcsolódik az adott ország napi politikai helyzetéhez.

\subsubsection{Egyéb megoldások}

Az utolsó kialakított kategória az olyan rendelkezéseket foglalja magában, amelyek nem sorolhatóak be egyik korábbi eljárási eszközhöz sem, azonban hatással vannak az alkotmánymódosítási eljárásra. Összesen tíz országnál találtam olyan jellemzőt, amely ebbe a csoportba került. ${ }^{383}$ Belgiumnál egyedi rendelkezések kerültek ide: mint számos más részénél a belga alkotmánynak, itt is találhatóak ún. Átmeneti rendelkezések, melyek speciális szabályok sokaságát tartalmazzák. ${ }^{384}$ Cipruson a már említett nemzetiségi arány szigorítja jelentős módon az alkotmánymódosítási eljárást. ${ }^{385}$ Észtország, Finnország és Svédország lehetőséget ad sürgősségi eljárásra speciális szabályok szerint. Svédország esetében különösen érdekes, hogy az ún. Alkotmányjogi

\footnotetext{
382 Spanyolország Alkotmánya 167. cikk

383 Belgium, Ciprus, Észtország, Finnország, Franciaország, Görögország, Portugália, Románia, Spanyolország, Svédország

${ }^{384}$ A Belga Királyság Alkotmánya 195. cikket követő Átmeneti rendelkezés

${ }^{385}$ Ciprus Alkotmánya 182. cikk (3)
} 
Bizottság dönt az eljárás felgyorsításáról; egyedi, hogy ilyen jogosultsággal rendelkezzen egy bizottság az alkotmánymódosítási eljárás során. ${ }^{386}$

Franciaországban, Romániában és Spanyolországban lehetőség van a parlament két házának közös ülésére bizonyos esetekben az alkotmánymódosítási eljárás során, mely megváltoztatja az eljárás menetét. Görögországban, ha nincs meg a szükséges többség az alkotmánymódosítás elfogadásához a parlamentben, viszont az abszolút többség kialakul, akkor a következő megválasztott parlament 3/5-ös többséggel elfogadhatja a módosításokat. ${ }^{387}$ Portugáliában pedig el lehet térni a moratóriumra vonatkozó föszabálytól 4/5-ös többséggel.

\subsection{A vizsgálat eredményei}

Az alkotmány módosításának eszközei befolyásolják az alkotmányok stabilitásának kérdését. Ennek során létrehoztam egy osztályozási rendszert a különböző eszközök megjelenésének értékelésére (egytől nyolcig), arra alapítva, hogy hány alkotmánymódosítási eszközt használ az adott ország. Ebből egy rangsor hozható létre, ha minden eszközt egy ponttal ,értékelünk”.

Az Egyesült Királyság alkotmányát nem lehetett vizsgálni ennek a szempontrendszernek a segítségével, nem rendeltem értéket hozzá. Az eredményeket a 2. ábra és a 2. táblázat foglalják össze.

Figyelembe véve a vizsgálat eredményét, a szlovák alkotmányt a legkönnyebb módosítani, mivel ehhez háromötödös parlamenti többség elengendö, és nincs más módosítási eszköz az alkotmányba foglalva, tehát az egy értéket rendeltem mellé. A második legegyszerübb módosítási eljárás a ciprusi alkotmányban található, a szükséges parlamenti többség kétharmados, azonban emellett külön el kell fogadnia a módosítást a görög és a török nemzetiségü képviselőknek is.

A legáltalánosabb eredmény a kettes, nyolc alkotmány használ kétféle különböző módosítási eszközt az alkotmánymódosítás során. ${ }^{388}$ Ausztria, Finnország, Hollandia, Lettország, Svédország és Szlovénia alkotmánya mellé a hármas értéket rendeltem az alkotmánymódosításra vonatkozó szabályaik alapján. Szintén hat ország: Belgium, Bulgária, Görögország, Luxemburg, Olaszország és Portugália mellé a négyes értéket rendeltem alkotmányuk szövegének megfelelően.

\footnotetext{
${ }^{386}$ A Svéd Királyság Alkotmánya Nyolcadik fejezet 15. cikk (1)

387 Görögország Alkotmánya 110. cikk (4)

${ }^{388}$ Ciprus, Csehország, Dánia, Horvátország, Írország, Magyarország, Málta és Németország.
} 
Négy országhoz rendeltem az ötös értéket: Franciaország, Lengyelország, Litvánia, Románia.

A legnehezebben módosítható, tehát a legmerevebb alkotmánnyal Észtország rendelkezik, alkotmánya mellé a hatos értéket rendeltem, vagyis alkotmánya hatféle módosítási eszköz alkalmazását írja elő (csak az alkotmányozó nemzetgyülés és a második kamara alkalmazása nem szerepel a szabályok között). A második legmerevebb alkotmány Spanyolországé, emellé szintén a hatos értéket rendeltem, bár itt inkább a speciális kérdésekre, speciális módokon lefolytatott eljárási szabályok miatt lett ilyen magas a szám, egy egyszerübb tárgyra vonatkozó alkotmánymódosításai eljárás nem annyira komplikált. Nem található olyan alkotmány a tagállamok között, mely mind a nyolc módosítási eszköz alkalmazását elöírná, egyik alkotmányozó sem érezte szükségét minden lehetséges módon nehezíteni az alkotmány módosítását.

Azonban egy alkotmány merevsége nem garancia arra nézve, hogy valóban hosszú ideig lesz hatályban, mivel ,,minden alkotmányos rendszernek képesnek kell lennie arra, hogy alkalmazkodjon a jövö változásaihoz, anélkül, hogy feláldozná szerepét mint a modern alkotmányos állam és az emberi jogok alapja”. ${ }^{389}$ Az alkotmány módosításának lehetnek más útjai is, pl. a bírói esetjog, ahogy ezt az Egyesült Államok alkotmányos hagyománya is példázza. Másfelől, ha nincs valódi lehetőség az alkotmány megváltoztatására, az elveszítheti legitimációját az állampolgárok szemében.

Azonban az a tény, hogy egy ország alkotmányát viszonylag könnyü vagy nehéz módosítani, nem jelenti azt minden esetben, hogy az káros is a konkrét ország vonatkozásában. Találhatunk olyan alkotmányt, melyet viszonylag könnyü módosítani, azonban elképzelhető, hogy nem volt még soha komoly igény az alkotmány módosítására, mivel nem történt az adott ország alkotmányos rendjében ehhez szükséges mértékű változás évtizedeken át, ezért stabil az alaptörvény. Másfelől, ha egy ország alkotmányát nehéz megváltoztatni, miközben alapvető változások történnek az adott ország alkotmányos rendszerében, az alkotmánymódosítás informális útjai (pl. bírói felülvizsgálat) kerülnek az előtérbe, hogy megerősítsék az alkotmányos rendszert.

Egyetértve Lutzzal, miszerint „,felfedezhetö egy »egészséges« minta, ahol az alkotmány rendszeresen, de olyan mértékben kerül megváltoztatásra, hogy lépést tudjon tartani a

389 BEKINK, BERNARD: Balancing constitutional stability and flexibility: An evaluation of the constitutional amendment procedures, Journal of South African Law, Vol. 2004, Issue 4 (2004), 672. p. 
változásokkal", 390 hozzátéve, hogy az adott ország egyedi körülményei mindig kiemelkedő jelentőséggel rendelkeznek az alkotmánymódosítás megvalósítása során.

Miután egy alkotmány hatályba lép, csak az idő mutatja majd meg, hogy milyen stabil. A „gazdasági, politikai és kulturális körülmények, valamint a megoldatlan problémák hatása bármely adott időpontban”391 megmutatják, hogy „,milyen sokáig maradhat hatályban egy alkotmány" módositások vagy új alkotmány elfogadása nélkül. "392 Az egyik ilyen faktor az „alkotmányos szerencse”, az az elem, amely az alkotmány kidolgozóinak hatáskörén kívül esik. ${ }^{393}$ A vizsgált állam demokratikus stabilitása is jelentős lehet az alkotmány módosításának szempontjából. ${ }^{394}$

A vizsgált tendenciák azt mutatják, hogy az „arany középút” országról országra eltérő, már a tagállamok esetében is. A „nem demokratikus” országok kérdése ettől igencsak különböző, eltérő problémákkal. ${ }^{395}$

Emellett az EU demokratikus alapelvei meghúzzák a tagállamok számára a határokat ebben a kérdésben. Az általános európai alkotmányos standardok megkötik a tagállamok kezét, hálót képezve alkotmányos értékeik körül, amelyen belül alakítják ki saját alkotmányos szabályaik.

\footnotetext{
${ }^{390}$ LUTZ 1995a, 262 p.

${ }^{391}$ RASCH - CONGLETON 2006, 548. p.

392 Más szemszögből: „minél öregebb az alkotmány, annál több lehetőség van alkotmányos változás mellett fellépni a társadalmi körülményekre és egyetértésre hivatkozva,". DIXON, RosALIND: Constitutional Amendment Rules: A Comparative Perspective, the University of Chicago Law School, Public Law and Legal Theory Working Paper Series, 347, May 2011, 106. p.

${ }^{393}$ BLOUNT - ELKINS - GINSBURG 2012, 43. p.

394 Például a török Alkotmánybíróság álláspontja szerint az egyetemeken való fejkendő-viselés veszélyezteti a demokráciát, mivel az egész alkotmányos rendszer szenzitív az országban. Lásd RozNAI, YANIV - YOLCU, SORKUN: An unconstitutional constitutional amendment - The Turkish perspective A comment on the Turkish Constitutional Court's headscarf decision, I-CON (2012) Vol. 110. No. 1, 186189. pp.

${ }^{395}$ GATMAYTAN 2010, 23-25. pp.
} 


\section{7. Örökkévaló-e a stabilitás? Az örökkévalósági klauzulák az alkotmány stabilitásának fókuszában}

Az alkotmány stabilitását elősegítő különböző módszerek közül itt csak a kifejezett örökkévalósági klauzulákkal foglalkozom, amelyek in concreto meghatározzák, hogy mely rendelkezések nem változtathatóak meg alkotmánymódosítással. $\mathrm{Az}$ örökkévalósági klauzulák az egyéb alkotmánymódosítási eljárási eszközöktől azért kezelendők külön, mivel ezek nem csupán megtörik az adott alkotmány szövegének egységes szintjét, bizonyos rendelkezéseket a többi felé emelve, hanem definiálják, hogy az adott alkotmányos rendszer mit tekint kiemelt, különösen védendő értéknek. Ezzel egy plusz megerősítést adnak az alkotmány stabilitásának, hiszen új védelmi szint alakul ki az alkotmánymódosítások esetében.

Az EU tagállamainak alkotmányait vizsgáltam ebből a szempontból, mivel azok az alapvető jogállamiság szemszögéből megfelelnek a mércének, és homogén csoportként lehet tekinteni rájuk. ${ }^{396}$

\subsection{Az örökkévalósági klauzula fogalmi keretei}

Az örökkévalósági klauzula az alkotmány olyan része, amelyet nem lehet megváltoztatni alkotmánymódosítással, hanem csak alkotmányozással, teljes alkotmányrevízióval. A fogalom előkérdése az alkotmányozás és az alkotmánymódosítás fogalmának elválasztása, itt csak jelzem, hogy az örökkévalósági klauzulák alkalmazásához elengedhetetlenül szükséges az alkotmánymódosítás és az alkotmányozás külön eljárásként való kezelése, hiszen pont az adja meg az örökkévalósági klauzulák feladatát, hogy az alkotmány bizonyos rendelkezéseit védik az alkotmánymódosítással szemben.

Az örökkévalósági klauzulák fogalma 2010 óta vált népszerübb témává a magyar szakirodalomban, ${ }^{397}$ az alkotmány védelmének új útjait keresők egyik kedvelt

\footnotetext{
${ }^{396}$ Emellett fontos megemlíteni, hogy nemcsak az európai alkotmányok tartalmaznak örökkévalósági klauzulákat, akár a szöveg szintjén, akár az alkotmányosságot vizsgáló testület feltáró munkája révén, lásd például: ROZNAI - YOLCU 2012, 175-207. pp., ROZNAI 2017, 42-69. pp.; KUMAR, VIRENDRA: Basic Structure of the Indian Constitution: Doctrine of Constitutionally Controlled Governance Ifrom Kesavananda Bharati to I.R: Coelho] Journal of the Indian Law Institute Vol. 49, No. 3 (July-September 2007) 365-398. pp.; WeINTAL, SHARON: The Challenge of Reconciling Constitutional Eternity Clauses with Populer Sovereignty: Toward Three-track Democracy in Israel as a Universal Holistic Constitutional System and Theory, Israel Law Review, 2011, Vol. 44, (449-497) 470 p., SMITH, EIVIND: Old and Protected? on the ,supra-constitutional" clause in the constitution of Norway. Israel Law Review, 2011, Vol. 44. 369-388. pp.
} 
hivatkozási pontja lett. ${ }^{398}$ Előtte a témával viszonylag keveset foglalkoztak a hazai jogirodalomban, ${ }^{399}$ mivel a magyar alkotmány nem tartalmazott örökkévalósági klauzulát, és Alkotmánybíróság is kizárta annak alkalmazását. ${ }^{400}$ Azonban az alkotmány gyakori $^{401}$ módosításának hatására növekedett az érdeklődés. Bár az Alaptörvény sem tartalmaz kifejezett örökkévalósági klauzulát, egyes álláspontok szerint felfedezhető benne. ${ }^{402}$

Az örökkévalósági klauzula fajtáit tekintve többféle csoportosítás is létezik. ${ }^{403} \mathrm{~A}$ következőkben csak a kifejezett örökkévalósági klauzulákat vizsgálom, mivel azok jelennek meg az alkotmányok szövegében. Az alkotmányértelmezésből származó ${ }^{404}$ örökkévalósági klauzulák szerepe kiemelkedő lehet egy olyan országban, ahol az alkotmány védelmében szükséges bizonyos rendelkezések magasabb szintre emelése, ${ }^{405}$ ám az európai alkotmánybíróságok kifejezett alkotmányba foglalás hiányában általában tartózkodnak ilyen fokú aktivizmustól, hiszen fennáll annak a veszélye, hogy az értelmező testület minél inkább kibontja a tartalmát a klauzulának, „úgy bővül láthatatlan módon az örökkévalósági klauzula terjedelme is. "406

Azonban az örökkévalósági klauzulákkal kapcsolatban felmerül az a probléma is, hogy mivel megváltoztatásuk nehezebb a többi alkotmányos rendelkezésnél, ezért a jövőbeli

\footnotetext{
${ }^{397}$ Számos értekezés vizsgálta az alkotmányellenes alkotmánymódosítás kérdését, ahol érintőlegesen előfordul az örökkévalósági klauzula is, azonban kifejezetten az örökkévalósági klauzulákkal foglalkozó tanulmányok pl.: BRAGYOVA - GÁRDOS-OROSZ 2016, 35-63. pp.; FRÖHLICH JOHANNA: Az örökkévalósági klauzulák dilemmája. in: DRINÓCZI TÍMEA - JAKAB ANDRÁS (szerk.): Alkotmányozás Magyarországon 2010-2011. Pázmány Press, Budapest-Pécs, 2013. 31-44. pp.; CHRONOwSKI - DRINÓCZI - ZELLER 2010, 1-12 pp.; KÜPPER, HERBERT: Az alkotmánymódositás és az alkotmánybírósági kontroll - megoldás az „örökkévalósági klauzula”? Közjogi Szemle 2013/4. 1-17. pp.; KÜPPER, HERBERT: Tur Tur, az álóriás? avagy a Grundgesetz örökkévalósági klauzulájának jelentése a német jogrendszerben. in: GÁRDOSOROSZ FRUZSINA - SZENTE ZOLTÁN (szerk.): Alkotmányozás és alkotmányjogi változások Európában és Magyarországon, Nemzeti Közszolgálati Egyetem Közigazgatás-tudományi Kar Budapest, 2014, 185194. pp.; CSINK - FRÖHLICH 2012a, 54. p, 57-59; SÓlYOM LÁSZLÓ: Normahierarchia az alkotmányban. Közjogi Szemle 2014/1. 1-7. pp.

${ }^{398}$ Az alkotmány „magja” bizonyos rendelkezéseinek igyekeztek fokozott védelmet nyújtani.

Lásd: VARGa Zs. ANDRÁs: A mag-alkotmány védelmében. Pázmány Law Working Papers, 2011/2. 1-5. pp.

399 Kivétel: BRAGYOVA ANDRÁs: Vannak-e megváltoztathatatlan normák az alkotmányban? In: BRAGYOVA ANDRÁS (szerk.): Ünnepi tanulmányok Holló András 60. születésnapjára. Bíbor Kiadó, Miskolc, 2003. 65-88 pp.; Említi: Sólyom 2001, 278. p., SZENTE ET AL. 2009, 557. p.; VinCZE ATTILA ET AL, 32/A. § [Az Alkotmánybíróság] In: JAKAB ANDRÁS (szerk.): Az Alkotmány kommentárja, I., Századvég Kiadó, Budapest, 2009. 1121. p.

${ }^{400}$ Pl.: 1260/B/1997 AB határozat, ABH 1998, 816, 23/1994. (IV. 29.) AB végzés, ABH 1994, 862.

401 2010-2012 között az Alkotmányt több, mint tízszer módosították.

402 BRAGYOVA - GÁRDOS-OROSZ 2016, 54-55. pp.

${ }^{403}$ FrÖHLICH 2013, 32. p.; BRAGYOVA - GÁRDOS-OROSZ 2016, 51-52. pp.; WeINTAL 2011, 460-463. pp.

${ }^{404}$ BRAGYOVA - GÁRDOS-OROSZ 2016, 52. p.

${ }^{405}$ Például Dél-afrikai Köztársaság, Törökország, India esete.

${ }^{406}$ FRÖHLICH 2013, 41. p.
} 
alkotmánymódosító hatalom előtt is gátat emel, a későbbi szuverént korlátozza az alkotmányozó hatalomhoz képest. Ennek az ellentétnek a feloldására alkalmas az az elmélet, amely szerint egyébként is csak az alkotmányozó által meghúzott határokon belül mozoghat az alkotmánymódosító hatalom. ${ }^{407}$

Az örökkévalósági klauzulák feladatukból adódóan kiemelkednek a többi alkotmányos rendelkezés közül, mivel kifejezetten rögzített, hogy alkotmánymódosítással nem, csak teljes alkotmányrevízióval változtathatóak meg. ${ }^{408}$ Ezzel mindenképp magasabb rangba kerülnek a többi alkotmányrészhez képest, mivel fokozottabb a védelmük.

Sharon Weinthal szerint az örökkévalósági klauzulák ,,(...) létrehozásuk célja a jövőbeli módositások ellenörzése abból a célból, hogy a forradalmiakat ne hagyják érvényesülni, (...)”, 409 tehát nemcsak magasabb „rangban” vannak, hanem egyfajta kontrollszerepük is van a többi rendelkezés felett. Meggátolják az alkotmányos rendszer gyökeres megváltoztatását, a „burkolt alkotmányozást”. Szerepük kiemelkedő lehet, ha valóban előfordul olyan eset, amikor szándék lenne az örökkévalósági klauzulába foglalt rendelkezés megváltoztatására, kikerülésére. ${ }^{410}$ Azonban, ha valós veszély fenyegeti az alkotmányos demokráciát, akkor komoly gyakorlati jelentősége lehet a nem megváltoztatható rendelkezéseknek.

A leggyakrabban hivatkozottak a német szövetségi alkotmányba foglalt örökkévalósági klauzulák, amelyek jelentőségének külön vizsgálata segíthet az örökkévalósági klauzulák általános szerepének bemutatásában. ${ }^{411}$

Herbert Küpper szerint a német örökkévalósági klauzulákat túlzott jelentőséggel ruházzák fel a nem német szerzők, hiszen még sosem került sor megsértésük megállapítására, és nem játszanak nagy szerepet a szakirodalomban sem. ${ }^{412} \mathrm{~A}$ védett cikkek tartalmának nem tulajdonítanak kiterjesztő értelmet, például a „,A demokráciával

\footnotetext{
${ }^{407}$ PETRÉTEI 2011, 71. p.

408 Az örökkévalósági klauzulák lehetséges nemzetközi szinten való felhasználásáról lásd: SzAKÁLY ZSUZSA: Human Rights, Civil Rights and Eternity Clauses. in: MARCEL SZABÓ ET AL. (szerk.): Hungarian Yearbook of International Law and European Law 2014, Eleven International Publishing, Hague, 2015. 271-273. pp.

${ }^{409}$ WEINTHAL 2011, 456. p.

${ }^{410}$ Például a leghíresebb, a német Alaptörvénybe foglalt örökkévalósági klauzulák alapján még sohasem állapított meg a német Szövetségi Alkotmánybíróság alkotmányellenes alkotmánymódosítást. Lásd: KÜPPER 2014, 185. p.

411 A német örökkévalósági klauzulákról részletesen lásd: GoERLICH, HELMUT: Concept of speial protection for certain elements and principles of the constitution against amendments and Article 79 (3), Basic Law of Germany. NUJS Law Review (2008) 1(3), 397-415. pp.

412 KÜPPER 2014, 185. p.
} 
és népszuverenitással kapcsolatban a demokrácia teljesen más formájának - például a prezidenciális vagy a radikálisan közvetlen demokráciának - a bevezetése is elfogadható lehet”, ${ }^{413}$ tehát nem kötötték meg az alkotmánymódosító hatalom kezét az örökkévalósági klauzuláknak nyilvánított kérdések kapcsán teljes mértékben, hanem megengedőbb hozzáállás alakult ki.

Először az ún. Southwest-case-ben vizsgálta a Német Szövetségi Alkotmánybíróság, hogy sérti-e a tartományokra vonatkozó örökkévalósági klauzulát a mai BadenWürttemberg területi kérdéseinek rendezése. ${ }^{414} \mathrm{Az}$ Alkotmánybíróság az örökkévalósági klauzulák szempontjából is vizsgálta a kérdést, és megállapította, hogy ez a szabályozás nem sérti az örökkévalósági klauzulába foglalt értéket. ${ }^{415}$

Nem is került sor megsértésük megállapítására, inkább mellékes kérdésként kerültek elő döntésekben. Akkor kaptak új szerepet, amikor a Német Szövetségi Alkotmánybíróság a német alkotmányos identitás részének minősítette az örökkévalósági klauzulákat, ${ }^{416}$ azonban nem történt még meg sértés megállapítása, valódi jelentőségre ebben a vonatkozásban sem tettek szert, viszont előtérbe kerültek, ${ }^{417}$ összekapcsolódva az alkotmányos identitás elméletével.

Preuss szerint az ,alapítási mítosz” alapvető részeit határozzák meg, „Ha $a z$ „örökkévaló” normatív kikötéseket megváltoztatnák, akkor az alkotmányba foglalt kollektív önértelmezése - vagy az identitása - a közösségnek összeomlana.",, ${ }^{418}$ vagyis nemcsak azt határozzák meg, hogy mely rendelkezéseket nem lehet alkotmánymódosítással megváltoztatni, hanem ezen túlmutatva az állam alapvető kérdéseit tartalmazzák, amelyek nélkül nem tud úgy müködni az ország, ahogy azt addig tette.

Ezzel a gondolattal párhuzamba állítható Küpper véleménye is: „ezek az elvek, értékek a mai német politikai kultúrának az alapját képezik, széles körü támogatást élveznek, és a nyilvánvaló felszámolásukra törekvö politika a választók többsége számára

\footnotetext{
${ }^{413}$ KÜPPER 2014, 190. p.

${ }^{414}$ Az ügy részleteit lásd: LeIBHOLZ, GeRHARD: The Federal Constituional Court in Germany and the „Southwest Case” The American Political Science Review Volume 4-6, Issue 3 September 1952, 724725. pp.

${ }^{415}$ LEIBHOLZ 1952, 728 p.

${ }^{416}$ Lásd részletesen: SCHÖNBERGER, CHRISTOPH: Lisbon in Karlsruhe: Maastricht's Epigones At Sea. German Law Journal; 10 (2009), 8. 1201-1218. pp.

417 PolZIN, MonIKa: Constitutional identity, unconstitutional amendments and the idea of constituent power: The development of the doctrine of constitutional identity in German constitutional law. International Journal of Constitutional Law, Volume 14 Number 2, 2016, 427-430. pp.

${ }^{418}$ PREUSS 2011, 445.
} 
elfogadhatatlan lenne.", ${ }^{419}$ vagyis van valódi jelentőségük, mert invokációjuk nélkül is határvonalat szabnak az alkotmányt módosító hatalom számára.

\section{2 Örökkévalósági klauzulák az Európai Unió tagállamainak alkotmányaiban}

Felmerül a kérdés, hogy a gyakorlatban milyen formában jelennek meg ezek a rendelkezések. Az EU tagállami alkotmányainak vizsgálatával kimutatható, hogy összesen hét ország ${ }^{420}$ alkotmányában van kifejezett örökkévalósági klauzula. A rendelkezéseket konkrétan az 5. táblázat mutatja a Mellékletben, a következő ábra pedig téma szerint csoportosítva ismerteti az örökkévalósági klauzulákat.

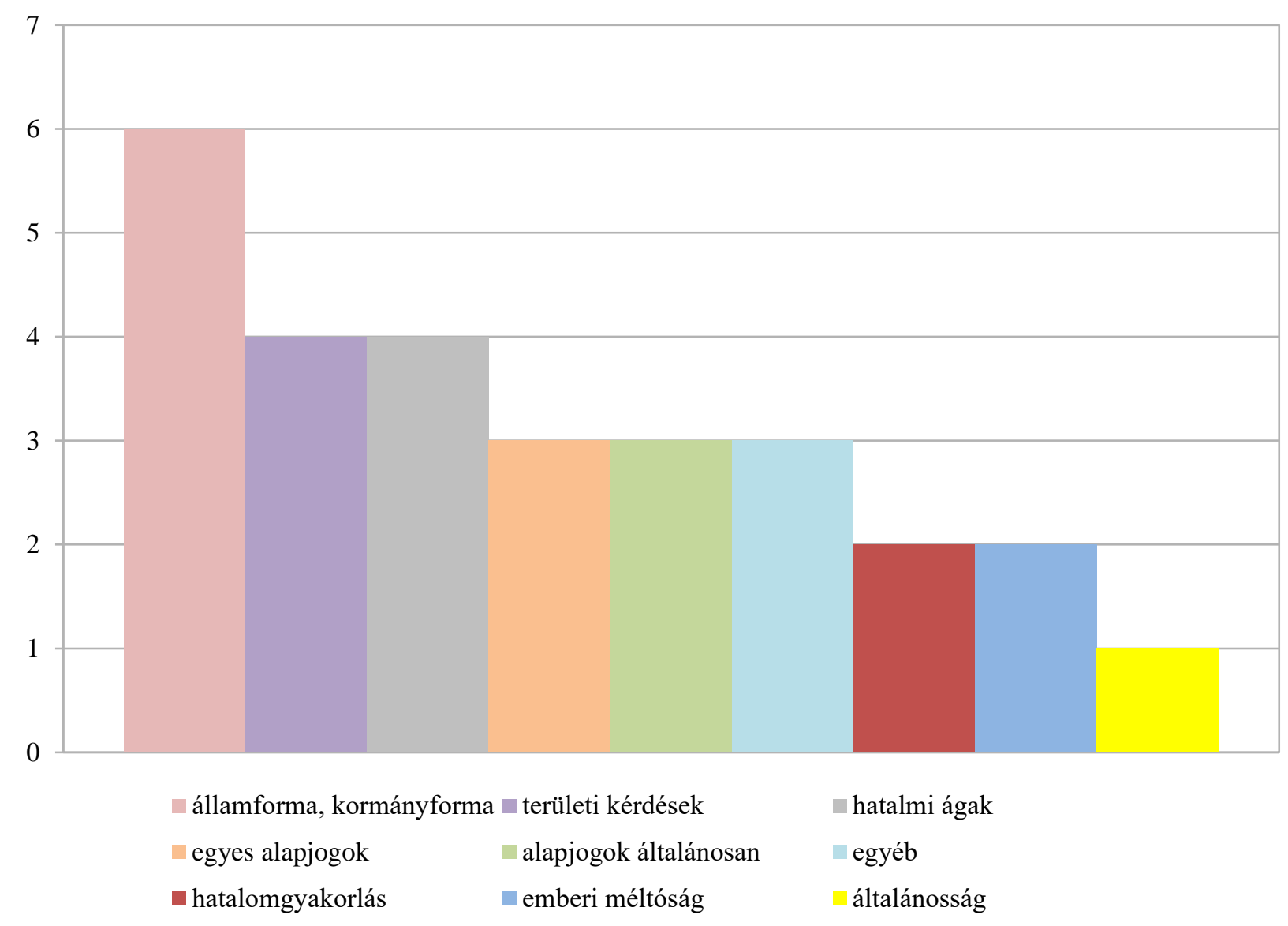

1. ábra. Az egyes örökkévalósági klauzulák előfordulásnak gyakorisága.

${ }^{419}$ KÜPPER 2014, 193. p.

${ }^{420}$ Csehország, Franciaország, Görögország, Olaszország, Németország, Portugália, Románia 
A grafikon az egyes örökkévalósági klauzulák téma alapján való csoportosítását mutatja gyakoriság szerint. (forrás: Nemzeti alkotmányok az Európai Unióban, saját feldolgozás).

Ha megnézzük az alkotmányok elfogadásának időszakát, megállapítható, hogy Csehországban, Görögországban, Olaszországban, Németországban, Portugáliában és Romániában diktatúra volt a ma hatályos alkotmány által meghatározott rendszer előtt. Franciaország nem vehető be ebbe a sorba, ott viszont a különösen instabil alkotmányos rendszer okozott komoly nehézségeket az ország müködésében 1958 előtt. ${ }^{421}$ Főként olyan európai országok alkalmazták tehát ezt az alkotmányvédelmi eszközt, ahol diktatúra vagy instabilitás volt, ezért különösen fontosnak minősülhetett bizonyos rendelkezések kiemelt védelme.

A vizsgálat során csoportokat alakítottam ki az örökkévalósági klauzulák tartalma szerint, ezek a 1. ábrán láthatóak. Számos különböző tárgykör számított a felsorolt országokban olyan komoly jelentőségünek, hogy ily módon igyekeztek minél magasabb szintű védelmet biztosítani számukra. Vannak olyan országok, ahol csak egy-két elvet foglaltak örökkévalósági klauzulába, míg máshol számos rendelkezés kapta meg ezt a kiemelt státuszt. Ezek közül a leggyakrabban védett tárgy a köztársasági államforma, összesen hat ország nyilvánította örökkévalósági klauzulának. ${ }^{422}$

A második leggyakrabban védelem alá helyezett elv négy ország alkotmányában lelhető fel, ez két alapelvre is igaz: a területi kérdések rögzítése ${ }^{423}$ és a hatalmi ágak elválasztása. ${ }^{424}$ Emellett védettek az alapjogok általában, ${ }^{425}$ valamint egyes kiemelt alapjogok, ${ }^{426}$ a hatalomgyakorlás formája, ${ }^{427}$ az emberi méltóság ${ }^{428}$ és a demokratikus jogállam lényeges elemei. ${ }^{429}$ Volt néhány egyéb védelemben részesülő rendelkezés, például a nemesi vagy más megkülönböztető címek tilalma, hivatalos nyelv, termelési eszközök tulajdona, stb. ${ }^{430}$

\footnotetext{
421 ÁDÁM 2007, 9-10. pp.

422 Franciaország, Görögország, Olaszország, Németország, Portugália, Románia

${ }^{423}$ Franciaország, Németország, Portugália, Románia

${ }^{424}$ Görögország, Németország, Portugália, Románia

425 Németország, Portugália, Románia

${ }^{426}$ Görögország, Németország, Portugália

${ }^{427}$ Németország, Portugália

${ }^{428}$ Görögország, Németország

${ }^{429}$ Csehország

${ }^{430}$ Görögország, Portugália, Románia
} 
Megállapítható, hogy a köztársasági államforma, a terület és az alapjogok valamely része védelmet élvez, a többi örökkévalósági klauzula esetén nehéz egységes irányt találni, inkább az adott ország politikai, társadalmi, gazdasági, történelmi körülményeinek hatására lett meghatározva, hogy mi kerül az örökkévalósági klauzulákba.

\subsubsection{Az államforma}

Az államforma kardinális kérdés, az adott ország alkotmányos berendezkedése szempontjából meghatározó. A republikanizmus jelenleg Európában a legelterjedtebb eszmerendszer, azonban ez még két évszázaddal korábban nem volt így. Bár San Marino 301 óta köztársaság, és Svájc, Hollandia, valamint Cromwell Angliája mind a monarchia ellenpéldájaként szolgáltak, a francia republikanizmus és az USA-beli republikanizmus $^{431}$ megjelenése indított el olyan komoly változásokat, melyek világszerte hatást gyakoroltak az alkotmányos fejlődésre.

Bár ma is sok a monarchia, számos ország történelme során változott az államforma többször is. A viharos események miatt nem egy ország döntött úgy, hogy a köztársasági államformát kiemelt védelemben részesíti. A következőkben ezek kerülnek bemutatásra, az adott történelmi helyzetet vizsgálva, (nem alkotmányos pillanatot keresve, Ackerman feltételrendszere szerint, hanem azt elemezve, hogy milyen történeti előzmény hatott a köztársasági államforma örökkévalósági klauzulává nyilvánítására).

Franciaországban 1792-től jelent meg a köztársasági államforma, amelyet kiemelten védenek az alkotmányi rendelkezések. Ez nem meglepő, hiszen „, a forradalmat követö kétszáz év története lényegében a köztársaság története annak ellenére is, hogy azt az alkotmányos monarchia illetve a császárság időszakai szakitották meg”." 432

A köztársasági több forrásból táplálkozik: „A felvilágosodás filozófiájából a Voltaire-i lelkiismereti szabadság és tolerancia, Montesquieu elmélete a hatalmi ágak szétválasztásáról, Rousseau népszuverenitás felfogása, a Concordet-i köztársaság gondolat, illetve a nevelés szerepének felismerése az állampolgárrá válásban". ${ }^{433} \mathrm{Az}$ 1958-as alkotmány elfogadása előtt többször felmerült a parlamentarizmus

\footnotetext{
431 VAJdA ZoLtáN: Republikanizmus az Amerikai Egyesült Allamok 18-19. századi történetében. http://www.aetas.hu/1998_4/republikanizmus.htm

432 NAGY MiKLós: A francia republikanizmus fó kérdései A republikánus hagyomány a francia köztársasági rendszerekben. $\mathrm{PhD}$ dolgozat, 2001. 13. p.

${ }^{433}$ NAGY 2001, 25. p.
} 
visszaszorítása, de ezt csak de Gaulle-nak sikerült megvalósítania. ${ }^{434}$ Republikánus a rendszer, amelyről azonban a következő volt a véleménye: „Az elnök szerepe szükségképpen monarchikus jellegü. Franciaországnak monarchiára van szüksége, nem isteni jogból eredö örökletes, hanem választási monarchiára. Én az egyeduralkodó funkcióját Franciaország nevében látom el". ${ }^{435}$ Tehát álláspontja szerint nem az a hangsúlyos, hogy mi maga az államforma, hanem az államfö feladatai gyakorlásának milyenségében látja a kulcsot.

Görögországban 1822 óta időszakosan megjelenik a köztársasági államforma, ${ }^{436}$ bár ez szinte évtizedenként változik: hol monarchia (különböző országokból származó uralkodókkal), hol köztársasági államforma jellemezte az országot. Az 1975-ös, ma is hatályos alkotmány a köztársasági államformát is kiemelt védelem alá helyezi, előtte a második világháborút követő időszaktól kezdve 1973-ig is királyság volt. ${ }^{437}$

Olaszországban a második világháború után egy viszonylag merev, a demokratikus rendszert őrző alkotmányt dolgoztak ki. ${ }^{438}$ Az alkotmány elfogadása előtt népszavazást tartottak az államforma kérdéséről, ahol szoros versenyben nyert a republikánus államforma, tehát itt valóban reális volt a köztársasági eszme védelmezőinek félelme. Volt valódi támogatói háttere a monarchiának, és a reális kockázat végett érthető az államforma örökkévalósági klauzulába foglalása.

Németország 1918 óta köztársaság, és az 1949-es bonni alkotmány is ezt erősítette meg. Az alkotmány nemcsak a köztársasági államformát védi, hanem a demokratikus és föderális jogállamot is, az 1949-es alkotmányozást megelőző eseményekből tanulva. ${ }^{439}$ Portugália 1910 óta köztársaság, 1933-ig diktatúra, majd a forradalmi helyzetet egy új rendszer váltott fel Salazar vezetésével. Ezzel azonban olyan problémák voltak, mint pl. a politikai pártok hiánya és a cenzúra. Salazar 1968-ban visszavonult a politikától, és egy 1974-es katonai megmozduláshoz csatlakoztak civilek milliói, amelynek eredménye forradalom és a diktatúra bukása lett, majd pedig az 1976-os alkotmány. ${ }^{440}$

\footnotetext{
434 ÁDÁM 2007, 20-21. pp.

${ }^{435}$ NAGY 2001, 121-122. p.

436 BALOGH ÁDÁM: Fejezetek Görögország újkori történetéböl A szabadságharctól napjainkig. Szeged, 2013. 25. p.

${ }^{437}$ BALOGH 2013, 108-109. pp.

438 MOLNÁR ANNA: Olaszország története a második köztársaság idején Az 'elsö köztársaság' összeomlásától Silvio Berlusconi negyedik kormányáig. Áron Kiadó, Budapest, 2011. 16-17. pp.

${ }^{439}$ PREUSS 2011, 439-440.

${ }^{440}$ SARAIVA, JosÉ HeRMANO: Portugália rövid története. Equinter, Budapest, 2010. 330-348. pp.
} 
Romániában a monarchikus hagyományok voltak erősek, még a második világháború után is csak 1948-ban szünt meg a monarchia. ${ }^{441}$ A rendszerváltozás utáni, 1991-es alkotmány az örökkévalósági klauzulák közé emelte a köztársasági államformát, különös súlyt adva ezzel a kérdésnek. Románia alkotmánya az egyik legmerevebb Európában, ${ }^{442}$ 2003-ban sikerült módosítani a parlamentnek hosszú idő után, ${ }^{443}$ mégis, a köztársasági államforma kiemelt védelme megmaradt, bár a közelmúltban felmerült ezzel ellentétes álláspont is. ${ }^{444}$

\subsubsection{Egységes nemzetállam}

Kiemel bizonyos, a területre vonatkozó rendelkezéseket a többi alkotmányos rendelkezés közül Franciaország, Németország, Portugália és Románia. A francia alkotmány szerint az alkotmánymódosítás nem érintheti a terület sérthetetlenségét. ${ }^{445} \mathrm{~A}$ portugál alkotmány a nemzeti függetlenség és egység védelmét emeli ki. ${ }^{446}$ Hasonló rendelkezést tartalmaz a román alkotmány, amely védi a terület integritását és az egységes, oszthatatlan államot. ${ }^{447}$ A német alkotmány tiltja a következők megváltoztatását: „a Szövetség tartományokra való felosztását, a tartományok alapvető közremüködését a törvényhozásban”. ${ }^{448} \mathrm{Az}$ államterület, amely a szuverenitás fontos eleme, különösen kiemelkedő azon országok számára, ahol ezt sérelem érte, változások voltak, vagy esetleg külső erők fenyegetése miatt érezték úgy, hogy fokozottabb védelemben részesítés szükséges.

\subsubsection{A hatalmi ágak elválasztása}

A hatalmi ágak elválasztása a demokrácia fontos alapelve, néhány ország pedig különös jelentőséget tulajdonít ennek a kérdésnek, örökkévalósági klauzulába foglalva ezt. A

\footnotetext{
${ }^{441}$ VARGA ATTILA: A román alkotmányozás és alkotmánymódositás sajátosságai (néhány formai, eljárási és tartalmi elem). Közjogi Szemle, 2014/3. 21.p.

442 BOzSÓ GÁBOR: Románia alkotmánya. Alkotmányelemzés. Pro Publico Bono Online Állam- és Közigazgatás-tudományi Szemle 2011/2. 6. p.

${ }^{443}$ VERESS EMŐD: Az alkotmánymódositás céljai és eredményei Romániában. Jura 2004/1. 79-80. pp.

444 A románoknál felvetődött a királyság visszaállítása https://index.hu/kulfold/2017/12/18/a_romanoknal_felvetodott_a_kiralysag_visszaallitasa/

${ }^{445}$ Franciaország alkotmánya 9. cikk (2)

${ }^{446}$ Portugália alkotmánya 288. cikk a)

${ }^{447}$ Románia alkotmánya 152 . cikk (1)

${ }^{448}$ Németországi Szövetségi Köztársaság Alaptörvénye 79. cikk (3)
} 
görög alkotmány meghatározza mindhárom hatalmi ág gyakorlásának letéteményesét azok külön kezelése érdekében. ${ }^{449}$

A német Alaptörvény szerint „,(3) A törvényhozást az alkotmányos rend, a végrehajtó hatalmat és az igazságszolgáltatást a törvény és jog köti.". ${ }^{450} \mathrm{Ez}$ korlátokat állít a mindhárom hatalmi ág elé. A portugál alkotmány elválasztja a hatalmi ágakat, megállapítja kölcsönös függőségüket, ${ }^{451}$ emellett külön pontba foglalja a bírói függetlenség eszméjét, ${ }^{452}$ azaz az igazságszolgáltatás kétszeres védelemben részesül. Romániában kiemelt szerepe van az alkotmányban az igazságszolgáltatás függetlenségének. ${ }^{453}$

A hatalmi ágak elválasztása, mint a demokrácia egyik legfontosabb sarokköve több ország alkotmányában is fokozott védelemben részesül, így biztosítva, hogy az adott országban ne jöhessen létre hatalomkoncentráció, hanem kiegyensúlyozott maradjon a hatalmi ágak müködése, érvényesülhessen a cheks and balances rendszere.

\subsubsection{Az alapjogok védelme}

Az örökkévalósági klauzulák között az alapjogvédelem kétfajta szempontból is megjelenik: egyik oldala az alapjogok általános védelme, másik oldala pedig az egyes alapjogok védelme. Itt különösen nagyok az egyes országok közötti különbségek. Az örökkévalósági klauzulákba foglalás biztosítja a kiemelt védelmet állami szinten.

Általánosságban illeti meg speciális védelem az alapjogokat Németországban, Portugáliában és Romániában. Mindhárom országban diktatúra volt a hatályos alkotmány elfogadása elött, tehát van közös pont az örökkévalósági klauzulákba foglalás mögött.

Ha megvizsgáljuk azokat az országokat, ahol az egyes alapjogokat kiemelt védelemben részesítették, ${ }^{454}$ ezért örökkévalósági klauzulákba foglalták, azt állapíthatjuk meg, hogy vélhetően az országok adott történeti helyzetére vezethető vissza a szándék.

Németországban a II. világháború után nemcsak az államformát igyekeztek kiemelt védelembe részesíteni, hanem az alapjogok általános védelmét is, valamint külön

\footnotetext{
${ }^{449}$ Görögország alkotmánya 26. cikk (1)-(3)

${ }^{450}$ Németországi Szövetségi Köztársaság Alaptörvénye 20. cikk (3)

${ }^{451}$ Portugália alkotmánya 288 . cikk j)

452 Portugália alkotmánya 288. cikk m)

${ }^{453}$ Románia alkotmánya 152 . cikk (1)

${ }^{454}$ Görögország, Németország, Portugália
} 
kiemelték az emberi méltóságot és az ellenállási jogot is, hogy minél magasabb szintü védelmet biztosítsanak a diktatúra kialakulásával szemben. ${ }^{455}$

Portugália és Görögország rendelkezik a legtöbb örökkévalósági klauzulával Európában. Mindkét országnak nagyon részletező az alkotmánya, ez az egyik oka a terjedelmes örökkévalósági katalógusnak, és a diktatúra elkerülésének érdekében igyekeztek minél több rendelkezést kiemelt védelem alá vonni. Így kerülhetett például a portugál örökkévalósági klauzulák közé a véleménynyilvánítás szabadsága, valamint a munkavállalók jogai. ${ }^{456}$

Görögországban ez a lista hosszabb. Az emberi méltóság mellett a lelkiismereti szabadság, a törvény elötti egyenlöség, a személyiség szabad kibontakoztatása és a személyi szabadság is örökkévalósági klauzulába lett foglalva. ${ }^{457}$ Ezek olyan első generációs alapvető jogok közé tartoznak, amelyek a demokratikus rendszer megszilárdításához nélkülözhetetlenek.

Kiemeli, ezáltal különösen magas szintü védelemben részesíti az emberi méltósághoz való jogot a görög és a német alkotmány. A görög rendelkezés ezt az állam alapvető kötelezettségeként határozza meg, ${ }^{458}$ a német pedig sérthetetlenségét is hangsúlyozza. ${ }^{459}$ Az emberi méltósághoz való jog valóban kiemelt helyet foglal el az alapjogi hierarchiában, ${ }^{460}$ védelemben részesítése pedig számos, belőle származó jogosultság számára is fokozottabb érvényesítési lehetőséget biztosít, ezáltal erősítve az alapjogvédelmi hálót.

\subsubsection{Hatalomgyakorlás és jogállamiság}

Külön csoportba kerültek azok a rendelkezések, amelyek bizonyos, a hatalom gyakorlásának mikéntjére vonatkozó rendelkezéseket tartalmaznak. Németország és Portugália alkotmányában találhatóak ilyen szakaszok. A német Alaptörvény védi a népszuverenitás eszméjét, emellett a történelmi tapasztalatokból okulva kizárja a közvetlen hatalomgyakorlás lehetőségét, kivéve a tartományok területi kérdését. ${ }^{461} \mathrm{~A}$ portugál alkotmány biztosítja a jogállamiságnak megfelelő választások

\footnotetext{
455 Németországi Szövetségi Köztársaság Alaptörvénye 1. cikk

${ }^{456}$ Portugália alkotmánya 288. cikk

457 Görögország alkotmánya 2. cikk (1); 5. cikk (1), (3); 13. cikk (1)

458 Görögország alkotmánya 2. cikk (1)

${ }^{459}$ Németországi Szövetségi Köztársaság Alaptörvénye 1. cikk (1)

${ }^{460}$ SólYOM 2001, 442-445. pp.

${ }^{461}$ Németországi Szövetségi Köztársaság Alaptörvénye 29. cikk
} 
megrendezését, ${ }^{462}$ valamint a helyi önkormányzatok önrendelkezési jogát, ${ }^{463}$ vagyis a lokális autonómiát. Ezek a rendelkezések kiemelt védelemben részesítik a demokratikus hatalomgyakorlás megvalósítását biztosító rendszer müködését, amely elengedhetetlen egy stabil, demokratikus rendszer fenntartásához, hiszen egyes hatalmi ágak túlhatalma veszélyezteti a demokráciát. ${ }^{464}$

Csehország alkotmánya szerint „A demokratikus jogállam lényeges elemei nem változtathatóak meg." ${ }^{465}$ A cseh alkotmányozó nem az egyes alapelvek felsorolása mellett döntött, nem egy katalógus mellett, hanem általában helyezte kiemelt alkotmányos védelem alá a demokratikus jogállam lényeges elemeit. Hogy mi tartozik ebbe a körbe? Ez könnyen tágítható fogalmi meghatározás, hiszen a jogállam fogalma is folyamatos változásnak van kitéve, tehát ez az örökkévalósági klauzula nemcsak a fogalmi keretét tekintve tág, hanem a kidolgozott fogalmi keret együtt tud változni az alkotmányos rendszerrel.

Hasonló rendelkezés található a norvég alkotmányban, amely szerint nem fogadható el olyan rendelkezés, amely megváltoztatná az alkotmány szellemiségét. ${ }^{466}$ Norvégia alkotmánya több, mint kétszáz éves -1814-ben fogadták el-, és hiányzik a mozgalmas történelmi háttér a többi örökkévalósági klauzulával rendelkező európai országhoz képest. Bár 1814-ben a Svédországgal való unió váltott ki ellenérzést a norvég népből, de majdnem 100 évig így működött a rendszer, amely aztán békés úton szünt meg, ${ }^{467}$ noha -majdnem- forradalmi helyzet is előállt az unió ideje alatt. ${ }^{468}$

\footnotetext{
462 Portugália alkotmánya 288. cikk h)

${ }^{463}$ Portugália alkotmánya 288. cikk n)

${ }^{464}$ DRINÓCZI 2016a, 85. p.

${ }^{465}$ Csehország alkotmánya 9. cikk. (2)

${ }^{466}$ Norvégia alkotmánya 121. cikk ,,If experience shows that any part of this Constitution of the Kingdom of Norway ought to be amended, the proposal to this effect shall be submitted to the first, second or third Storting after a new parliamentary election and be publicly announced in print. But it shall be left to the first, second or third Storting after the following parliamentary election to decide whether or not the proposed amendment shall be adopted. Such an amendment must never, however, contradict the principles embodied in this Constitution, but solely relate to modifications of particular provisions which do not alter the spirit of the Constitution, and two thirds of the Storting must agree with such an amendment. An amendment to the Constitution adopted in the manner aforesaid shall be signed by the President and the Secretary of the Storting, and shall be sent to the King for public announcement in print as an applicable provision of the Constitution of the Kingdom of Norway."

${ }^{467}$ LeES-SMITH, Hastings. B.: The Parliamentary System in Norway. Journal of Comparative Legislation and International Law Third Series, Vol. 5, No. 1, 1923. 35-37. pp.

468 Borgeaud, Charles: Adoption and Amendment of Constitutions in Europe and America, Translated by Hazen Charles D., Professor of History in Smith College. With an introduction by Vincent John M., Associate of the Johns Hopkins University. New York and London: Macmillan and Co. 1895. Pp. xi, 353. 101-102. pp.
} 
Mivel ez az egyik legrégebben hatályban levő alkotmány a világon, az örökkévalósági klauzula létét nem a XX. századi diktatórikus berendezkedés tanulságai igazolják, azonban fontos megjegyezni, hogy a norvég alkotmány a hosszú dán uralom után született meg, tehát mégis szembehelyezkedett az előző ,,rendszerrel”. ${ }^{469}$ Mára ez a rendelkezés a demokratikus gyakorlat alapelvévé vált, ${ }^{470}$ bár használata gyakoribb volt a XIX. században és a XX. század elején. ${ }^{471}$

\subsubsection{Egyéb}

Ebbe a kategóriába a lehető legvegyesebb rendelkezések kerültek, amelyek egyik korábban vizsgált csoportba sem illettek. Ilyen rendelkezés például a görög alkotmány azon cikke, amely tiltja a nemesi vagy más megkülönböztető címeket a jogegyenlőség jegyében, ${ }^{472}$ a portugál alkotmánynak az a pontja, amely szerint nem lehet alkotmánymódosítással megváltoztatni „a gazdasági terv szerepét a vegyes gazdálkodás keretei között;", 473 vagy a román alkotmány hivatalos nyelvet védő szakasza. ${ }^{474}$ Ezek a kazuisztikus rendelkezések az alkotmányozói szándéknak köszönhetően kaptak fokozott védelmet.

\subsection{Az örökkévalósági klauzulák szerepe az alkotmány stabilitásának védelmében}

Az EU tagállamainak alkotmányaiban található kifejezett örökkévalósági klauzulák színes képet mutatnak, ahogy az a 5. táblázatban látható. Céljuk minden esetben az, hogy meghatározott rendelkezéseket kiemelt védelemben részesítsenek a napi politikai játszmákkal szemben, és különös figyelem kísérhesse megváltoztatásukat, mivel az csak alkotmányozással lehetséges. Az örökkévalósági klauzulák nemcsak az alkotmányba foglalt bizonyos rendelkezéseket védik, hanem a demokráciát, a jogállamiságot, vagy magát az egységes nemzetállamot és az államformát. Ezáltal szimbolikus jelentőséget nyernek, hiszen kiemelkednek az alkotmány szövegéből, „,egyenlőbbekké” válnak az egyenlök között és a bennük foglaltak jelentősége hangsúlyosabbá válik. Közös pont,

\footnotetext{
${ }^{469}$ BALOGH ElEMÉR: 200 éves a norvég alkotmány. Alkotmánybírósági Szemle, 2014/1. 111-112. pp.

${ }^{470}$ OPSAHL, TORKEL: The Reflection of Social Values in the Constitutional History of Norway - Some Illustrations. 15 Holdsworth L. Review, 181, 1991-1992. 185. p.

${ }^{471}$ SMITH 2011, 383-384. p.

${ }^{472}$ Görögország alkotmánya 4. cikk (7)

473 Portugália alkotmánya 288. cikk g)

${ }^{474}$ Románia alkotmánya 152 . cikk (2)
} 
hogy tipikusan olyan országok fordultak ehhez az eszközhöz, ahol az alkotmány hatályba lépése előtt diktatúra volt, gyengék voltak a demokratikus hagyományok, ezért is érezhették különösen fontosnak örökkévalósági klauzulák alkalmazását.

A Grundgesetz előkészítésekor azért merült fel az alkotmánymódosító hatalom korlátozásának gondolata, hogy egy esetleges forradalom esetén ne merülhessen fel annak legitim volta, védelmezzék a szabadságot és a demokratikus rendet. ${ }^{475}$ Hasonló motivációi lehettek a többi alkotmányozónak is az örökkévalósági klauzulák alkotmányba emelésekor.

Az alkotmány stabilitását úgy is védelmezhetjük, ha bizonyos, az alkotmány alapját, mondhatni magját képező rendelkezéseket kiemelünk a többi közül, és fokozott védelemben részesítjük. Ha más, relatíve kisebb súllyal bíró rendelkezések meg is változnak, az alkotmányos rendszer alapkövei a helyükön maradnak.

Ezen rendelkezések megváltoztatása különösen nehézkes, hiszen maga az alkotmánymódosítási eljárás is bonyolultabb, mint egy egyszerü törvénymódosítás, egy új alkotmány elfogadása ehhez képest is hosszú folyamat.

Abban az esetben, ha ilyen rendelkezést akar megváltoztatni az alkotmánymódosító hatalom, és van az országban alkotmánybíróság, ez a testület léphet fel az alkotmányellenes alkotmánymódosítással szemben (lásd a 11. fejezetet). Az örökkévalósági klauzulák védik a bennük foglalt rendelkezéseket, az alkotmány szövegének meghatározott részeit, elősegítve az adott alkotmány stabilitásának erōsítését.

Több vizsgált országban azért nincs gyakorlati jelentősége az örökkévalósági klauzuláknak, mivel nem fenyegeti mára valós veszély a bennük foglalt, védendő alapértékeket, ${ }^{476}$ mint ahogyan bevezetésük elött. ${ }^{477} \mathrm{Az}$ örökkévalósági klauzulák gyakorlati használatának valós jelentőségéről ír Szente Zoltán az alkotmányellenes alkotmánymódosítások kérdése kapcsán. ${ }^{478}$ Felhívja a figyelmet arra, hogy ilyen rendelkezések hiányában nehezen igazolható hierarchiát kialakítani az alkotmányos rendelkezések között. ${ }^{479}$ Sólyom László szerint az Alkotmánybíróság kialakított egy

\footnotetext{
475 POLZIN 2016, 422-424. pp.

476 KÜPPER 2014, 187. p.

477 Németország esetében lásd: PREUSS 2011, 441. p.

${ }^{478}$ SZENTE 2014, 219-221. pp.

${ }^{479}$ SZENTE 2014, 223. p.
} 
világos alapjogi hierarchiát, anyagi jogi sorrendet. ${ }^{480}$ Viszont külön kategóriát képeznek az alkotmány és a rá épülő rendszer önazonosságát meghatározó rendelkezések. ${ }^{481}$

Az önazonosság kérdésével összekapcsolva már új irányba mutat az örökkévalósági klauzulák vizsgálata, különösen, ha a történeti alkotmány vívmányait is bevonjuk az értelmezési körbe, ahogy az a 9. fejezetben történik.

${ }^{480}$ SÓLYOM 2014, 2. p.

${ }^{481}$ SÓLYOM 2014, 4. p. 


\section{Múlt és jövő az Európai Unió tagállamaiban az alkotmány preambulumában}

„[...] minden törvénynek megvan a maga természetes bevezetése, és annak, aki törvényhozásba fog, valamennyi szövegrész éle odaillö, a »rátermett» bevezetést kell helyeznie: hisz nem kis dolog, ami utána következik, és nagy különbség van a között, hogy világosan véssük-e a törvényt az emlékezetünkbe, vagy sem; [...]",482

Az alkotmányi preambulumok témáját már többen vizsgálták Magyarországon, értéktani, ${ }^{483}$ történeti, ${ }^{484}$ összehasonlító, ${ }^{485}$ nyelvfilozófiai ${ }^{486}$ és hazai jogfejlődési ${ }^{487}$ szempontból. Most nem célom ezek ismétlése, hanem a fogalmi keret megrajzolása és az összehasonlító példák után a Nemzeti Hitvallás elemzése abból a szempontból, hogy alkalmas-e az alkotmány stabilitásának erősítésére, kiemelve az ahhoz kapcsolódó alkotmánybírósági gyakorlatot. ${ }^{488}$

482 Platón összes müvei kommentárokkal. Törvények Szerk: MIKLÓs TAMÁs, Atlantisz, 2008. 723c.

${ }^{483}$ FEKETE BALÁzS: A jéghegy csúcsa. Strukturális értékek az európai alkotmányok preambulumaiban. In: FEKETE BALÁZS - HORVÁTHY BALÁZS - KREISZ BRIGITTA (szerk.): A világ mi magunk vagyunk... Liber Amicorum Imre Vörös. HvgOrac Lap- és Könyvkiadó Kft., 2014. 136-147. pp.

${ }^{484}$ KUKORELli ISTVÁN - MÁTHÉ GÁBOR: Közjogi értékeink a preambulumban. In: LAMM VANDA MAJTÉNYI BALÁZS - PAP ANDRÁS LÁSZLÓ (szerk.): Preambulum az alkotmányokban, Complex, 2011. 922. pp.; NAGY ATtILA TIBOR: A magyar múlt a preambulumban. in: ANTAL ATTILA - NovÁK ZOLTÁN SZENTPÉTERI NAGY RICHARD (szerk.): Az Alkotmány arca Preambulum-tanulmányok. L’Harmattan, Budapest, 2011.

94-106. pp.; TRÓCSÁNYI 2014, 52-55. pp.

${ }^{485}$ FEKETE BALÁZS: Történeti elemek az EU-tagállamok alkotmány-preambulumaiban. In: LAMM VANDA - MAJTÉNYI BALÁZS - PAP ANDRÁS LÁSZLÓ (szerk.): Preambulum az alkotmányokban. Complex, 2011. 33-46. pp; PAÁR ÁDÁM: Európa preambulumai. in: ANTAL ATTILA - NovÁK ZOLTÁN - SZENTPÉTERI NAGY RICHARD (szerk.): Az Alkotmány arca Preambulum-tanulmányok. L’Harmattan, Budapest, 2011. 107-122. pp.; VARGA CSABA: Preambulumok az alkotmányi gyakorlatban. Iustum Aequum Salutare, 2010/4. 217-241. pp.

486 FEKETE BALÁZS: Preambulumok és nyelvfilozófia avagy a preambulum normativitásáról másképp. Pázmány Law Working Papers 2011/33. 1-12. pp.

487 TRÓCSÁNYI 2014, 56-69; ANTAL ATTILA: A preambulum ornamentikája és közjogi ereje. in: ANTAL ATTILA - NovÁK ZOLTÁN - SzEnTPÉTERI NAGY RICHARD (szerk.): Az Alkotmány arca Preambulumtanulmányok, L’Harmattan, Budapest, 2011. 31-40. pp.; VÖRÖS IMRE: Preambulumot az alkotmányhoz de milyet? In: LAMM VANDA - MAJTÉNYI BALÁZS - PAP ANDRÁS LÁSZLÓ (szerk.): Preambulum az alkotmányokban, Complex, 2011. 23-32. pp.; HORKAY HÖRCHER FERENC: A Nemzeti hitvallásról. In: JAKAB ANDRÁS -KÖRÖSÉNYI ANDRÁS (szerk.): Alkotmányozás Magyarországon és máshol. Politikatudományi és alkotmányjogi megközelítések. MTA Társadalomtudományi Kutatóközpont Politikatudományi Intézet - Új Mandátum Könyvkiadó, Budapest. 2012. 287-309. pp.

${ }^{488}$ A fejezet az alábbi munka átdolgozott és aktualizált változata: SZAKÁLY ZSUZSA: Múlt és jövő értékei az Európai Unió tagállamaiban az alkotmány preambulumában, különös tekintettel a Nemzeti Hitvallásra. Fontes Iuris, 2017/4. szám, 56-63. pp. 
Az alkotmány megalkotásának történelmi pillanatában óhatatlanul felmerül a késztetés a múlt jó példáinak felhasználására, valamint a jövő szebbé tételének a szándéka is felbukkan. Ezeknek a hatásoknak köszönhetően számos alkotmány-preambulum tartalmaz a múltra és/vagy a jövőre vonatkozó rendelkezéseket.

$\mathrm{Az}$ alkotmányok preambulumai többféle szerepet is betölthetnek. Amellett, hogy ünnepélyességükkel felhívják a figyelmet az egész dokumentum fontosságára, normatív jelentőségük is lehet. ${ }^{489}$ Politikai-szimbolikus jelentőségük azonban nagyobb jogitartalmi jelentőségüknél. ${ }^{490}$

A magyar Alaptörvény preambulumának feladata ehhez képest speciális, mivel külön alkotmányos rendelkezés szól róla. ${ }^{491}$

Egy új alkotmány elfogadására általában valamilyen kiemelkedő eseményhez kapcsolódóan kerül sor, gyakran forradalmi pillanatban. Azonban bizonyos alkotmányos pillanatokban ${ }^{492}$ felmerül a múlthoz való viszony, néha pedig a jövő kérdése is az alkotmányozók részéről. Vajon ezek preambulumban való megjelenése bírhat-e olyan jelentőséggel, amelynek gyakorlati szempontból is szerep jut az alkotmány értelmezése során, a magyar Alaptörvény preambulumában található rendelkezések fényében?

A preambulumok egyes elemeit az alábbiak szerint csoportosítja a Sulyok-Trócsányi szerzőpáros:

- önmeghatározás,

- a jogalkotói hatalom eredetére, esetleg terjedelmére, illetve tárgyára (mandátum) tett utalás,

- a célok és étékek deklarálása,

- történelmi narratíva,

- $\quad$ egyéb elemek. ${ }^{493}$

${ }^{489}$ VARGA 2010, 220-224. pp.; SULYOK - TRÓCSÁNYI 2009, 90-91. pp. Sőt, normatívnak is tekinthetőek, lásd: TótH JUDIT: Jogalkotástan. Egyetemi jegyzet, Szegedi Tudományegyetem ÁJTK, $2016,24$.

${ }^{490}$ JAKAB ANDRÁs: Mire jó egy alkotmány? Kommentár 2010/6.

${ }^{491}$ Magyarország Alaptörvénye (2011. április 25.) R) cikk „(3) Az Alaptörvény rendelkezéseit azok céljával, a benne foglalt Nemzeti hitvallással és történeti alkotmányunk vívmányaival összhangban kell értelmezni."

492 ACKERMAN 1993, 266-269. pp.

493 SULYOK - TRÓCSÁNYI 2009, 91. p. 
Ezek közül itt a történelmi narratívához kapcsolódó elemeket vizsgálom, valamint a jövőre tett utalásokat is, mivel azok ugyanúgy hozzájárulhatnak az alkotmány megszilárdításához.

Az alkotmányozó hatalom mindig értékek között választ, sohasem értéksemleges, ${ }^{494}$ és ezek az értékek -vagy legalábbis egy részük - megjelenik a preambulumban is. Az európai alkotmányok preambulumainak értékszempontú elemzése során Fekete Balázs a következő módon helyezi el a két vizsgált témakört: a történeti kérdésre vonatkozó részt az államisággal kapcsolatos értékek közé sorolja, a jövőre (generációkra) vonatkozó részt pedig a társadalmi léttel kapcsolatos kérdések közé. ${ }^{495}$ A történelmi hagyományt mint értékhivatkozást hét ország alkotmány-preambulumában fedezte fel, amelynél jelen írás tágabban kezeli a történelmi narratívát. Ettől eltérő módon jelen esetben nem a preambulum-részek által hordozott értékek kerülnek vizsgálatra, hanem az, hogy milyen lehetőségeket nyithatnak a felhasználásukra. Az angol-amerikai felfogás általában nem tulajdonít normatív erőt a preambulum-szövegnek, de a gyakorlat ingadozó. ${ }^{496}$

Bár az EU tagállamainak alkotmányos hagyományában nincs standard a preambulumokra vonatkozóan, ${ }^{497}$ érdemes megvizsgálni a nyilvánvalóan bevezetőnek szánt szövegekben ${ }^{498}$ található utalásokat a múltra és a jövőre nézve. A 3. táblázat mutatja, hogy mely tagállami alkotmányokban találhatóak ilyen jellegű rendelkezések.

\subsection{A múlt az EU tagállamok alkotmányainak preambulumaiban}

A történelmi hagyományok összesen 12 alkotmány preambulumában jelennek meg az EU-ban. ${ }^{499}$ Ezt nem az alkotmány elfogadásához kapcsoltam, mert akkor lehetővé válna a bővebb körben való vizsgálódás, ${ }^{500}$ hanem az alkotmány elfogadását megelőző történelmi eseményekhez.

Ahogy a felsorolásból látható, a múlttal foglalkozó alkotmány-preambulumok többsége az új demokráciákhoz tartozó országok alkotmányában jelent meg, ugyanis ezek „,fö

\footnotetext{
${ }^{494}$ PETRÉTEI 2011, 76. p.

${ }^{495}$ FEKETE 2014 143. p.

${ }^{496}$ Lásd: VARGA 2010, 220. p.

${ }^{497}$ CDL-AD(2011)016, 8. p.

498 A preambulum nélküli alkotmányok első pár szakasza általában preambulum-stílusú és témájú, Ld. pl. finn alkotmány 1-5. cikk, máltai alkotmány 1-6. cikk

499 Csehország, Észtország, Franciaország, Horvátország, Írország, Lengyelország, Lettország, Litvánia, Magyarország, Portugália, Szlovákia, Szlovénia

${ }^{500}$ FEKETE 2011, 41-43. pp.
} 
funkciója az identitásteremtés, amelynek kialakulása egyértelmüen az 1989-ben kezdödö rendszerváltozásokkal függ össze. "501

Ezek közül a leghosszabb a horvát alkotmány vonatkozó része, amelyben 14 külön kijelentés található, amelyek a horvát történelem különböző mérföldköveit emelik ki. ${ }^{502}$ Több ország is említi a küzdelmeket, amelyek eredményeként elnyerték függetlenségüket, önállóságukat, ${ }^{503}$ ami nem meglepő, hiszen a vizsgált államok nagy része 1989 után vált függetlenné. Így önmeghatározásukban fontos szerepet játszik annak kinyilvánítása, hogy önálló államiságuk elnyerték.

Ez a gondolat azonban nemcsak a szovjet befolyás alatt álló országok alkotmánypreambulumában lelhető fel, hanem Írország alkotmány-preambulumában is. A szöveg szerint az alkotmányozók ,,hálásan emlékezve hösies és lankadatlan küzdelmükre, hogy visszanyerjék Nemzetünk jogos függetlenségét"504 emlékeznek saját múltjuk eseményeire, amelyek befolyásolják a jelen alkotmányozóit is. Írország történelmére gondolva, különös tekintettel a több évszázados brit uralomra, valóban különleges jelentőség tulajdonítható az elért függetlenségnek.

Néhány ország a korábbi történelmi állapotára való hivatkozással erősíti a kontinuitást, ${ }^{505}$ azonban csak kettő, Lettország és Magyarország nyilvánítja ki konkrétan, hogy nem fogadja el a megelőző időkben érvényesülő diktatúrát. ${ }^{506} \mathrm{~A}$ lett preambulum, bár elítéli a diktatúrát, és nem fogadta el az elnyomást, de nem megy el odáig, mint a magyar preambulum, amely kinyilvánítja az 1949-es alkotmány

${ }^{501}$ Berkes Lilla - FeKeTE BALÁzs: Nemzeti Hitvallás: csupán díszitó szavak? Közjogi Szemle 2017/1. szám 15. p.

502 Például: Horvátország alkotmánya „Az 1712. évi Pragmatica Sanctió elfogadásáról önálló és szuverén parlamenti határozatban;”, ,abban a tényben, hogy a Horvát országgyülés soha nem szentesitette a Szlovénok, Horvátok és Szerbek Állami Nemzeti Tanácsának határozatát a Szerbiával és Montenegróval való egyesülésröl a Szerbek, Horvátok és Szlovénok Királyságában (1918. december 1-jén), amely később (1929. október 3.) Jugoszláv Királyságnak kiáltotta ki magát;"” stb.

503 Írország, Lengyelország, Lettország, Litvánia, Magyarország, Portugália, Szlovákia, Szlovénia

504 Írország alkotmánya

505 Észtország, Horvátország, Lengyelország, Lettország, Litvánia, Magyarország, Szlovákia

${ }^{506}$ Lettország alkotmánya „Lettország népe nem fogadta el az öt elfoglaló rezsimeket, ellenállt azoknak és visszaszerezte szabadságát, mikor 1990. május 4-én visszaállitotta nemzeti függetlenségét az állam folytonosságának alapkövén. Tiszteleg szabadságharcosai elött, emléket állit az idegen erök áldozatai elött, elitéli a kommunista és nemzetszocialista totalitárius rezsimeket és azok büneit."

Magyarország: „Nem ismerjük el történeti alkotmányunk idegen megszállások miatt bekövetkezett felfüggesztését. Tagadjuk a magyar nemzet és polgárai ellen a nemzetiszocialista és a kommunista diktatúra uralma alatt elkövetett embertelen bünök elévülését.

Nem ismerjük el az 1949. évi kommunista alkotmányt, mert egy zsarnoki uralom alapja volt, ezért kinyilvánitjuk érvénytelenségét."

„Hazánk 1944. március tizenkilencedikén elveszitett állami önrendelkezésének visszaálltát 1990. május másodikától, az elsö szabadon választott népképviselet megalakulásától számítjuk. Ezt a napot tekintjük hazánk új demokráciája és alkotmányos rendje kezdetének."

Alaptörvény 
érvénytelenségét. Ez a kijelentés elvezethet ahhoz a gondolathoz, hogy az 1949-1989 között alkotott jogszabályok is elveszítik érvényességüket ezen okból. ${ }^{507}$ Bár ezt cáfolhatnánk a preambulum általános normatív erejének vizsgálatával, ${ }^{508}$ viszont a magyar Alaptörvény R) cikk (3) bekezdése más megvilágításba helyezi ezt a kérdést.

Több preambulum-szöveg említi az ország hagyományait, mint fontos értéket. ${ }^{509} \mathrm{Ez}$ lehet keresztény, ${ }^{510}$ kulturális ${ }^{511}$ vagy jogi, ${ }^{512}$ esetleg ,jó", ${ }^{513}$ azonban akkor érik el céljukat, ha lehetővé teszik bizonyos értékek esetleges beemelését a gyakorlatba, ahogy ezt a magyar Alaptörvény preambulumának esetében az R) cikk konkrétan ki is mondja. $\mathrm{Az}$ önrendelkezés/önállóság/függetlenség is több preambulumban megjelenő motívum, ${ }^{514}$ amely az állami szuverenitás kinyilvánításának fontos eszköze, hiszen az adott állam önállósága teszi lehetővé az alkotmányozást, biztosítva a szuverénnek, hogy megalapozza az ország alkotmányos müködésének rendjét. Ebben a kérdésben is Horvátországé a legjelentősebb mennyiségű deklaráció, összesen nyolcszor említi a preambulum az önállóság/önazonosság gondolatát. ${ }^{515}$ A cél ebben az esetben is az, hogy már az alkotmány bevezetésében rögzítsék az ország függetlenségének alapjait. Horvátország és Szlovénia alkotmány-preambuluma emellett a nemzeti önazonosság gondolatát is megjeleníti, abban a kontextusban, hogy azt a múlt formálta.

Az ősökre való utalás is megjelenik néhány preambulum-szövegben, ${ }^{516}$ megjelenítve a hagyományok, a „régi jó szokás”, valamint az ország történetének kontinuitását bemutatva az ország nemzetközi jelentőségét, amely hosszabb történelmi időszakra nyúlik vissza.

Franciaország alkotmány-preambuluma emellett az 1789-es Deklarációban, az 1946-os alkotmány preambulumában és a Környezeti Kartában meghatározott alapelvekhez való ragaszkodást is tartalmaz, vagyis a hatályos alkotmány részévé teszi a preambulum

\footnotetext{
${ }^{507}$ Ennek cáfolata: SZENTE 2011, 10. p.

${ }^{508}$ VARGA 2010. 220-224. pp.

${ }^{509}$ Csehország, Horvátország, Lengyelország, Lettország

${ }^{510}$ Lengyelország

${ }^{511}$ Lettország

512 Horvátország

${ }^{513}$ Csehország

514 Csehország. Észtország, Horvátország, Írország, Lengyelország, Lettország, Litvánia, Magyarország, Szlovákia, Szlovénia

${ }^{515}$ Horvátország alkotmánya

516 Csehország - „ősi államiság”, Lengyelország - „hálás szívvel őseinknek”, Litvánia - „,szabadon éljen és tevékenykedjen atyái és ősatyái földjén”, Magyarország - „Büszkék vagyunk az országunk megmaradásáért, szabadságáért és függetlenségéért küzdő őseinkre."
} 
segítségével ezeknek a dokumentumoknak a vonatkozó részeit. ${ }^{517}$ Ezzel a speciális megoldással lehetővé vált az ezekbe foglalt alapelvek felhasználása az Alkotmánytanács gyakorlatában, kialakítva az ún. ,alkotmányos blokkot”. ${ }^{518}$ Ezzel valódi jelentőségre tett szert a preambulumba foglalt rendelkezés, kiterjesztette az alkotmányba foglalt jogokat a meghatározott dokumentumok tartalmával, lehetôvé téve hivatkozásukat az Alkotmánytanács számára. Az alkotmányos blokk akár párhuzamba állítható a történeti alkotmány vívmányaival, hiszen az alkotmány szövegétől különálló dokumentumba foglalt, más időpontban keletkezett jogi szövegek meghatározott részeit, amelyek kiemelet jelentőséggel bírnak, részévé teszi az alkotmány szövegében foglaltak szerint az alkotmány legfőbb értelmezője ítélkezési gyakorlatának, meghatározva szerepük. A hasonlóság természetesen nem teljes, hiszen míg a magyar Alkotmánybíróság az Alaptörvény felhatalmazása alapján szabadon válogathat a különböző, történeti alkotmány részét képző jogszabályokba foglalt elvek között, a francia Alkotmánytanács ezt mindössze három dokumentum esetében teheti meg. Azonban a mögöttes gondolat ugyanaz: az alkotmány felhatalmazása alapján más szövegekben foglaltak bázisként való használata a konkrét jogi probléma vizsgálata során.

Az alkotmány-preambulumokban megjelenő történelmi értékeknek tehát első olvasatra a dicső múlt, valamint az alkotmányozást megelőző diktatúrától való elhatárolódás a feladata, azonban megtalálható bennük az a cél is, hogy hangsúlyozzák az adott állam jelentőségét, kinyilvánítsa önállóságát, függetlenségét, szuverenitását.

A történelmi múlt jelentős eseményei, a hagyományok, az ősök, az önállóság alkotmány-preambulumba foglalása hozzájárul ahhoz, hogy megteremtse a kapcsolatot a múlt és a jelen között, ezzel segítve az alkotmány stabilitását, hiszen a múlthoz való kapcsolódás egy olyan pont, amelynek hatására az elfogadott szöveg tisztelete nagyobb lesz, ha nem elfogult történelemszemléletre épül, azaz a társadalom képes azonosulni az értékekkel.

\footnotetext{
${ }^{517}$ Franciaország alkotmánya

518 A „Fundamental Principles recognized by the Statutes of the Republic”-al kiegészülve. PHILIPPE, XAVIER: Constitutional Review in France: the Extended Role of the Conseil constitutionnel through the New Priority Preliminary Rulings Procedure (QPC). 53 Annales U. Sci. Budapestinensis Rolando Eotvos Nominatae 3 (2012) 66. pp.
} 


\subsection{A jövő az EU tagállamok alkotmányainak preambulumaiban}

A jövő, a fejlödés is felfedezhető az EU tagállamai alkotmányainak preambulumaiban több helyen, bár nem annyira népszerủ ez a gondolat, mint a történelmi múlt említése. Összesen kilenc ország alkotmányának preambuluma említi a progressziót és a jövő generációkat. ${ }^{519} \mathrm{~A}$ jövő generációk jogainak kérdése nemrég kezdett szélesebb körben ismertté válni a fenntartható fejlödéssel karöltve. Egyre több EU-n kívüli országban jelenik meg az alkotmányban a fenntartható fejlödés mint cél, bár inkább magában a szövegben, ${ }^{520}$ mintsem a preambulumban. Kivételt képez ez alól Montenegró, ahol a preambulumban jelenik meg a fenntartható fejlödés gondolata. ${ }^{521}$

Az EU tagállamainak alkotmányait vizsgálva az általános fejlődést támogató deklarációk ${ }^{522}$ mellett található kifejezetten a fenntartható fejlődésre ${ }^{523}$ és a jövő generációkra $^{524}$ vonatkozó kifejezés is felbukkan a preambulumokban. Legrészletesebben a magyar Alaptörvény taglalja ezt a kérdést, többször is előkerül a Nemzeti Hitvallásban. ${ }^{525}$

A környezetvédelem felértékelödésével a fenntartható fejlődés, a jövő generációk számára a megfelelö környezet biztositásának gondolata is elötérbe került. A dicső történelmi tettek felemlegetése mellett több alkotmány is foglalkozik a jövővel, hiszen egy alkotmányt megalkotásakor általában nemcsak egy generációnak szánnak. Felmerülhet az a gondolat is, amely szerint már a jelenben úgy kell cselekedni, hogy a jövőben is biztosított legyen a megfelelő, élhető környezet a jövő generációi számára. ${ }^{526}$

519 Csehország, Észtország, Franciaország, Horvátország, Lengyelország, Lettország, Litvánia, Magyarország, Portugália, Spanyolország, Szlovákia

520 A teljesség igénye nélkül: fenntartható fejlődés: Albánia 59. cikk (1)f); El Salvador 117. cikk; Grúzia 37. cikk (4); Mauritánia19. cikk; Peru 69. cikk; Dél-Afrikai Köztársaság 25. cikk b) iii; Szerbia 97. cikk 9.; Zimbabwe 73. cikk 1. iii.

Jövő generációk jogai: Angola 39. cikk (2); Bolívia 108. cikk 15.; Egyiptom 32., 46., 78. cikk; Malawi 13. cikk d) iii; Mozambik 117. cikk (2) d); Tunézia 129. cikk

${ }^{521}$ Montenegró alkotmánya, Preambulum

522 Csehország, Észtország, Franciaország, Horvátország, Lengyelország, Lettország, Magyarország, Portugália, Spanyolország, Szlovákia,

${ }^{523}$ Lettország

524 Észtország, Lengyelország, Lettország, Magyarország

525 „Bízunk a közösen alakitott jövöben, a fiatal nemzedékek elhivatottságában”, „Alaptörvényünk jogrendünk alapja, szövetség a múlt, a jelen és a jövö magyarjai között.”, „Felelösséget viselünk utódainkért, ezért anyagi, szellemi és természeti eröforrásaink gondos használatával védelmezzük az utánunk jövö nemzedékek életfeltételeit."

Alaptörvény

526 Ahogy azt az USA alkotmányának preambuluma is megfogalmazta: „,...] biztositsuk a szabadság áldásait magunk és utódaink számára," 
A francia alkotmány preambuluma speciális abból a szempontból, hogy nem mondja ki a fenntartható fejlődésnek, a jövő nemzedékek jogainak támogatását in concreto, csak a 2004-es Környezetvédelmi Kartát említi meg az 1789-es Deklaráció és az 1946-os alkotmány preambuluma mellett, mint a jogok alapját. A Karta tartalmaz mind a jövő generációkra, mind a fenntartható fejlődésre vonatkozó részeket. A francia megoldás jó példaként szolgálhat, bár a megoldás egyedisége miatt nem biztos, hogy népszerüvé válhat.

Észtország alkotmánya támogatja a ,,jelen és jövő generációk általános fejlődését”, 527 míg a lengyel alkotmány így fogalmaz: ,érezve a kötelezettséget, hogy ezer éves örökségünk mindezen értékeit a jövő generációkra hagyományozzuk”, 528 Lettország „egyéne” pedig ,felelősen cselekszik más népekkel, a jövö generációival, a környezettel és a természettel szemben." 529 Megjelenik tehát annak a kötelezettségnek az érzete, hogy a jelen alkotmányozói munkájának eredménye a jövő generációk számára is előnyös legyen, felelős cselekvést várható el a jövő generációk tagjaival szemben.

Portugália alkotmánya szerint az új alkotmány feladata, hogy „,megnyissa az utat egy szocialista társadalom felé a portugál nép akaratának megfelelően egy még szabadabb, még igazságosabb és még emberibb ország épitése érdekében." 530 Vagyis az alkotmánynak irányt kell mutatnia a jelenlegi és jövőbeli állampolgárok számára annak érdekében, hogy egy jobb jövő jöhessen létre. Ez kissé naivnak tünhet, azonban megjeleníti az alkotmánynak azt a feladatát, hogy hosszú távra határozza meg a társadalmi együttélés alapvető kereteit. Az átmeneti alkotmányokkal szemben a klasszikus értelemben vett alkotmányok kifejezetten hosszú távú hatályban maradásra tervezettek.

A preambulumok ünnepélyessége tünik fel a jövőre utaló rendelkezések vonatkozásában is, amelyeket akár túlzónak is tekinthetünk, azonban pont preambulumszöveg voltuk miatt válnak elfogadhatóvá, ugyanis a bennük foglaltak az alkotmány normatív részében nem volnának reálisnak tekinthetőek, például a lengyel preambulum szerint: „vágyakozva arra, hogy minden időkre biztositsuk az állampolgárok jogait és az állami szervek müködésének gyorsaságát és

\footnotetext{
527 Észtország alkotmánya

${ }^{528}$ Lengyelország alkotmánya

${ }^{529}$ Lettország alkotmánya

${ }^{530}$ Portugália alkotmánya
} 
hatékonyságát", ${ }^{531}$ vagy a magyar Nemzeti Hitvallás következő részét tekintve is megerősíthető ez a megállapítás: „Hisszük, hogy gyermekeink és unokáink tehetségükkel, kitartásukkal és lelkierejükkel ismét naggyá teszik Magyarországot. "532

A jövő nemzedékek jogainak, a fenntartható fejlödésnek a megjelenése az alkotmány preambulumában elősegítheti a stabilitás megerösítését, hiszen a jövő generációk „közelebb” érezhetik magukhoz a szöveget, ha beépül a gyakorlatba, hogy tekintettel kell lenni a jövöbeli szempontokra is, hogy az eljövendő nemzedékek számára is biztosítottak legyenek a Föld kincsei. Ha az alkotmányozó kinyilatkoztatása nem csak üres frázis, hanem van mögötte valós szándék, annak nagy horderejü következményei is lehetnek. Egy ilyen erővel rendelkező alkotmányos kinyilatkoztatás az egész alkotmány tiszteletét fokozhatja az állampolgárok előtt.

\subsection{A Nemzeti Hitvallás múltra és jövőre utaló rendelkezései}

A fentiek fényében érdemes alaposabban megvizsgálni a magyar Alaptörvény preambulumának, a Nemzeti Hitvallásnak ${ }^{533}$ vonatkozó rendelkezéseit. A magyar preambulum elég hosszú, a múlt és a jövő tárgyában is részletesebb, explicitebb rendelkezéseket tartalmaz az átlagosnál.

Talán az is volt az alkotmányozó célja, hogy az 1949. XX. törvény lakonikus preambulumához ${ }^{534}$ képest erőteljesebb hatást keltő szöveg kerüljön az Alaptörvénybe, hiszen a hosszabb, ünnepélyesebb preambulumok hatnak az érzelmekre, és az ehhez visszatérés növeli a lojalitást, erősíti a történeti kontinuitást.

A VB megvizsgálta az Alaptörvény preambulumát, és több kérdésben is aggodalmát fejezte ki, például a preambulum értelmezési gyakorlatba való bevonásának lehetősége miatt, mivel egymással ellentétes vélemények is kialakíthatóak a szöveg különböző részei alapján. 535

A különböző történelmi eseményekre utaló részek szép számmal találhatóak a Nemzeti Hitvallásban. A Szent Korona-tan kapcsolódó értelmezési lehetőségeiről, ${ }^{536}$ a

\footnotetext{
${ }^{531}$ Lengyelország alkotmánya

${ }^{532}$ Magyarország Alaptörvénye

${ }^{533}$ Az elnevezésről részletesebben lásd: HORKAY HÖRCHER 2012, 293-294. pp.

534 TRÓCSÁNYI 2014, 60. p.

${ }^{535}$ CDL-AD(2011)016. 8. p

${ }^{536}$ SZENTE 2011, 1-13. pp.
} 
nemzetfogalom értelmezéséről, ${ }^{537}$ a történeti alkotmány vívmányairól, ${ }^{538}$ a 28 . cikk szerinti értelmezésről ${ }^{539}$ már számos vélemény formálódott, de a történeti és a jövőre utaló elemek alkotmány-stabilitást erősítő szerepét még nem vizsgálták.

„Felelösséget viselünk utódainkért, ezért anyagi, szellemi és természeti erőforrásaink gondos használatával védelmezzük az utánunk jövő nemzedékek életfeltételeit. "540

A fenntartható fejlődés fontossága a P) cikkben is megjelenik, ${ }^{541}$ valamint a környezetvédelem növekvő nemzetközi jelentőségére is elég utalni. ${ }^{542}$ A magyar jövő nemzedékek érdekeinek védelmét ellátó biztoshelyettes feladatai a környezetvédelemhez kötődnek, az alapvető jogok biztosa pedig a gyermeki jogok védelmét látja el. A jövő nemzedékek jogaival nem foglalkozik kiemelten a biztoshelyettes. A 2008-2009-es beszámolóban bár van egy külön fejezet „A jövő nemzedékek kilátásai Magyarországon” címmel, azonban ez kizárólag környezetvédelmi szempontokat vizsgál. ${ }^{543}$ Ugyanez a helyzet a 2010 -es, ${ }^{544} 2011$-es ${ }^{545}$ beszámolóval is. 2012-től az Alapvető Jogok Biztosának Hivatala már közös beszámolókat ad ki, alapjogok szerinti csoportosítással; a ,jövő generációk” elnevezés ugyan megjelenik a 2012-es, ${ }^{546} 2013$-as, ${ }^{547}$ a 2014-es ${ }^{548}$ beszámolóban, de kétséges, hogy ehhez milyen alapjogok kapcsolhatók. A 2014-es beszámolótól ismét külön

${ }^{537}$ SMUK 2013, 259-271. pp.

${ }^{538}$ Lásd: RIXER ÁDÁM: A történeti alkotmány lehetséges jelentéstartalmai. Jogelméleti Szemle, 2011/3.; CSINK - FRÖHLICH 2012b, 10-11. pp., ORBÁN 2013, 51-58. pp., MiláNKOVICH - SZENTGÁli-Tóth 2014., 65-74. pp.

${ }^{539}$ CSINK - FRÖHLICH 2012a, 130-131. pp.

${ }^{540}$ Alaptörvény

$\left.{ }^{541} \mathrm{P}\right)$ cikk „(1) A természeti eröforrások, különösen a termöföld, az erdök és a vizkészlet, a biológiai sokféleség, különösen a honos növény-és állatfajok, valamint a kulturális értékek a nemzet közös örökségét képezik, amelynek védelme, fenntartása és a jövö nemzedékek számára való megörzése az állam és mindenki kötelessége."

${ }^{542}$ Lásd: HoRVÁth GeRgelY: Az Alaptörvény környezetjogi elöírásai. In: SzoboszlaI-Kiss KatAliN Deli GeRGely (szerk.): Tanulmányok a 70 éves Bihari Mihály tiszteletére. Györ, Universitas-Györ, 2013. 222-234. pp.

${ }^{543}$ A jövő nemzedékek országgyülési biztosának beszámolója 2008-2009, Budapest, 2010, 246-278. pp.

544 Beszámoló a jövő nemzedékek országgyülési biztosának 2010. évi tevékenyégéről, Budapest, 2011, 214-281. pp.

${ }^{545}$ Beszámoló a jövő nemzedékek országgyülési biztosának 2011. évi tevékenyégéről 321-356. pp.

${ }^{546}$ Beszámoló az alapvető jogok biztosának és helyetteseinek 2012. évi tevékenységéről, Alapvető Jogok Biztosának Hivatala, 2013, 169-197. pp.

547 Beszámoló az alapvető jogok biztosának és helyetteseinek tevékenységéről 2013, Alapvető Jogok Biztosának Hivatala, 2014, 90-99. pp., 261-285. pp. A gyermekjogok is megjelennek külön fejezetként, külön fejezetet kap a jövő nemzedékek biztoshelyettese is, ahol szinte csak környezetvédelmi kérdések kerülnek elötérbe.

548 Beszámoló az alapvető jogok biztosának és helyetteseinek tevékenységéről 2014, Alapvető Jogok Biztosának Hivatala, 2015, 92-100. pp. 
fejezetben követhető a biztoshelyettes tevékenysége. ${ }^{549}$ A 2015-ös beszámoló a környezetvédelmi kérdések mellett ${ }^{550}$ a jövő generációk jogainak védelmében folytatott nemzetközi párbeszédet is bemutatja, amelyben közremüködött a magyar biztoshelyettes, ${ }^{551}$ ahogyan teszi ezt a 2016-os beszámolóban is. ${ }^{552}$

„Bízunk a közösen alakitott jövőben, a fiatal nemzedékek elhivatottságában. Hisszük, hogy gyermekeink és unokáink tehetségükkel, kitartásukkal és lelkierejükkel ismét naggyá teszik Magyarországot. "553

Ez a kijelentés inkább szimbolikus, mint gyakorlati jelentőségü, legfeljebb verbálisan hangsúlyozza a jövőt és a fiatal nemzedékeket.

„Alaptörvényünk jogrendünk alapja, szövetség a múlt, a jelen és a jövő magyarjai között. Élö keret, amely kifejezi a nemzet akaratát, azt a formát, amelyben élni szeretnénk. "554

Az elemzés szempontjából a múlt, a jelen és a jövő magyarjai közti kapcsolat bír jelentőséggel, mert ebben fedezhető fel az a gondolat, amely szerint egymást követő generációk számára kell az alkotmánynak megfelelő alkotmányos keretet biztosítania az állam működéséhez. Ez részleteiben változhat, de maga a kezdetekkor megalkotott keret megmarad, a basic structure ${ }^{555}$ ugyanaz lehet az évtizedek, akár évszázadok alatt, tehát részleges, a fő alappilléreket nem érintő értelmezési változás vagy formális módosítás lehetséges, azonban az alapnak ugyanannak kell maradnia. Ha nem, akkor új alkotmányt kell elfogadni, tehát ebből a szempontból el kell választani az alkotmányozó és az alkotmánymódosító hatalmat. ${ }^{556}$

A kijelentés másik eleme az ,élő keret”. Az élő alkotmány doktrínája szerint az alkotmány organikusan fejlődik, változik, nem egy kötött jelentéstartalmú szöveg,

\footnotetext{
549 Beszámoló az alapvető jogok biztosának és helyetteseinek tevékenységéről 2014, Alapvető Jogok Biztosának Hivatala, 2015, 256-282. pp.

${ }^{550}$ Beszámoló az alapvető jogok biztosának és helyetteseinek tevékenységéről 2015, Alapvető Jogok Biztosának Hivatala, 2016, 252-294. pp.

551 Beszámoló az alapvető jogok biztosának és helyetteseinek tevékenységéről 2015, Alapvető Jogok Biztosának Hivatala, 2016, 267-271. pp.

552 Beszámoló az alapvető jogok biztosának és helyetteseinek tevékenységéről 2016, Alapvető Jogok Biztosának Hivatala, 2017, 330-333. pp., 320-364. pp.

553 Alaptörvény

554 Alaptörvény

${ }^{555}$ Az indiai Legfelső Bíróság által kialakított doktrína, mely szerint az alkotmány ,,alapvető szerkezetét” nem lehet megváltoztatni alkotmánymódosítással, a folyamatról Ld. pl.: KUMAR 2007, 365-398. pp.

${ }^{556}$ PETRÉTEI 2011, 78-80. pp.
} 
hanem folyton változó, azaz élő keret. ${ }^{557}$ Ez különösen a common law országokban széles körben alkalmazott, ahol a bírói jogértelmezés teszi valóságossá ennek a metaforának a használatát. ${ }^{558} \mathrm{Az}$ alkotmánybíróságok gyakorlata is mutat hasonló jegyeket, különösen, ha aktív a testület, megváltoztathatja bizonyos rendelkezések értelmezési tartományát, akár teljesen új jelentés társításával. Erre a klasszikus példa az USA Legfelső Bíróságának gyakorlata, miszerint a korábbi jelentéssel ellentétes értelmet tulajdonított bizonyos kijelentésnek, ${ }^{559}$ vagy teljesen új jogosultságot „látott bele" egy-egy alkotmányos passzusba, ${ }^{560}$ melynek eredményeként használható az 1789es szöveg a modern idők kihívásai között is. Az originalista álláspont szerint a szöveg eredeti értelmének megfelelően kell megtenni az interpretációt. ${ }^{561}$

A változó értelmezési gyakorlat akár az alkotmány preambulumára is vonatkozhat, ahogy ez az USA esetében megtörtént. Amíg 1905-ben a preambulumot kizárták az értelmezési tartományból, ${ }^{562}$ addig 1973-ban éppen a preambulum szövege segített támpontot találni a kívánt célhoz a Legfelső Bíróság számára. ${ }^{563}$

\subsubsection{A preambulum hatása az értelmezési gyakorlatra}

A korábbi alkotmány preambulumával foglalkozott az Alkotmánybíróság, több esetben is vizsgálta a szöveget. ${ }^{564} \mathrm{Az}$ Alaptörvény hatályba lépésével új helyzet jött létre, mivel az R) cikk (3) szerint „Az Alaptörvény rendelkezéseit azok céljával, a benne foglalt Nemzeti hitvallással és történeti alkotmányunk vívmányaival összhangban kell értelmezni.". ${ }^{565}$ Mivel az Alaptörvényt erga omnes hatállyal az Alkotmánybíróság értelmezheti, a testületre várt a feladat, hogy kialakítsa ezt az új értelmezést, mely még nem alakult átfogó rendszerré.

557 PAKSY MÁTÉ: Az alkotmányértelmezés müvészete Kanadában. Iustum Aequum Salutare, 2012/1. 7582. pp.

${ }^{558}$ Kavanagh, AILEen: The Idea of a Living Constitution, Canadian Journal of Law and Jurisprudence, 16(1), 2003. 55-57. pp.

559 Brown v. Board of Education of Topeka, 347 U.S. 483 (1954)

${ }^{560}$ James Obergefell, et al., Petitioners v. Richard Hodges, Director, Ohio Department of Health, et al. 2015; Jane Roe, et al. v. Henry Wade, District Attorney of Dallas County, 1973.

${ }^{561}$ KAVANAGH 2003, 63-64. pp.

562 Harlan elvette a jogi erejét a preambulumnak „Az Egyesült Államok egyetlen lényeges hatalma sem származik az alkotmány preambulumából.” Jacobson v. Massachusetts, 197 U.S. 11 (1905)

563 ORgaD, LiAv: The Preamble in Constitutional Interpretation. Icon 2010 Vol. 8 No. 4. 721. p.

564 TRÓCSÁNYI 2014 60-62. pp.

565 Alaptörvény 
A történeti alkotmány vívmányainak értelmezése külön értekezés tárgya lehetne, most csak utalok arra, hogy ezzel szélesítheti az érvelési palettáját az Alkotmánybíróság, noha pro és kontra érveket bőven találunk. ${ }^{566}$

A történeti alkotmány vívmányai mellett a többi kifejezés is veszélyes lehet, ${ }^{567}$ mert utat engedhet meröben új értelmezésnek.

Akár a kereszténység nemzetmegtartó szerepét figyelembe véve, akár a kommunista rendszer tagadását tekintve, ha normatív tartalmat tulajdonítunk nekik, súlyos következményekkel számolhatunk (például ha a kereszténység nemzetmegtartó szerepének különös jelentőséget tulajdonítunk, akkor a kereszténység többi valláshoz képest kiemelt szerepbe kerül, ellentmondva a vallások egyenjogúságának. A másik hipotetikus eset az, amikor valóban érvénytelennek tekintjük az 1944-1990 közötti időszak szuverenitáshiányos rendszerét, akkor érvénytelenné válnak az akkor keletkezett jogszabályok és az azokra épülő jogviszonyok is). ${ }^{568}$

A hipotetikus kérdésen túl, vajon milyen valós esetekben használta az Alkotmánybíróság a Nemzeti Hitvallás valamely gondolatát döntéshozatala során? A gyakorlat vizsgálatából összegyüjtött ügyekből azokat mutatom be, melyekben nemcsak az indítványozó, ${ }^{569}$ hanem a testület is felvetette érdemben a Nemzeti Hitvallás valamely részét a döntéshozatal során.

„,Valljuk, hogy népuralom csak ott van, ahol az állam szolgálja polgárait, ügyeiket méltányosan, visszaélés és részrehajlás nélkül intézi. "570

A 21/2013 (VII. 19.) határozatában az Alkotmánybíróság megállapította a közérdekü adatok megismerésével kapcsolatosan, hogy „Ez az elv - a Nemzeti hitvallásban foglaltakat figyelembe véve - nem csak a közpénzek és a nemzeti vagyonra vonatkozó, hanem általában véve a közfeladatok ellátásával összefüggő adatok kezelése szempontjából is irányadó. ”. 571 Felhívta a figyelmet a testület arra, hogy „Ennél fogva a polgárait szolgáló demokratikus állam müködésének egészével, általánosságban a

\footnotetext{
566 VÖRÖs IMRE: A történeti alkotmány az Alkotmánybiróság gyakorlatában. Közjogi Szemle, 2016/4. 4457. pp; SZMODIS JENÖ: Az alkotmányos történelmi vívmányok szerepéröl a normakontrollban Széljegyzetek Vörös Imre akadémiai székfoglaló elöadásához. Jogelméleti Szemle 2016/4. 176-183. pp.; SZALMA JÓZSEF: A történelmi/történeti és a kartális alkotmány teljességéröl és jogalkalmazási kérdéseiröl. Jogelméleti Szemle 2017/2. 187-188. pp.

567 VÖRÖs 2016a, 54-55. pp.

568 SZENTE 2011, 10. p.

${ }^{569}$ Az indítványozók Nemzeti Hitvallást használó érvelését is elemzi: BERKES - FEKETE 2017, 17-18. pp.

570 Alaptörvény

571 21/2013. (VII. 19.) AB határozat [32]
} 
közfeladatok ellátásával kapcsolatos alaptörvényi követelmény tehát az átláthatóság és a közélet tisztasága, valamint a közügyek méltányos, visszaélés és részrehajlás nélküli intézése.". 572

A 35/2014. (XII. 18.) AB határozat a jogállamiság elvével kapcsolatban vetette fel a vizsgált gondolatot a Nemzeti Hitvallásból, hozzátéve, hogy a közhatalmat gyakorló szerveknek e szerint kell eljárniuk. ${ }^{573}$

A 3070/2017. (IV. 19.) AB határozat esetében egy közszolgálati jogviszonyban álló személy közszolgálati jogviszonyát szüntették meg arra tekintettel, hogy polgármesterjelöltként tanúsított magatartása méltatlanságot eredményezett. Az indítványozó véleménynyilvánításhoz való jogának sérelmével fordult az Alkotmánybírósághoz a rendes bírósági lehetőségek kimerítése után. A testület vizsgálata során foglalkozott a Nemzeti Hitvallás vonatkozó részével is, és megállapította, hogy

„A Nemzeti hitvallás fenti mondata ezért értékdeklaráció is, amely alkotmányos értékként fogalmazza meg, hogy a demokratikus jogállamban az államigazgatási szervezetrendszerben dolgozók arra hivatottak, hogy munkájukkal az állampolgárokat szolgálják. Az ő munkájuk teremti meg a közhatalmat gyakorló szervek iránti közbizalmat, ezen alkotmányos érték érvényesitése tehát a közhivatal viselöjével szemben elvárás egy demokratikus jogállamban. "574

Ennek következtében a közszolgálati jogviszony lehet alapjog-korlátozó hatású, és megvalósulhat a méltatlanság, mivel „A közszolgálati jogviszonyban álló személyeknek a közügyek szabad megvitatása során is be kell tartaniuk a közhivatal viseléséhez kapcsolódó törvényi elöirásokat." 575

„Valljuk az elesettek és a szegények megsegitésének kötelességét."576 versus „szülőtartás”

A 27/2013. (X. 9.) határozatában az Alkotmánybíróság rokkantnyugdíjból élő személy szülőtartási kötelezettségét vizsgálta, és kimondta a testület, hogy

„Az Alkotmánybiróság - hivatalból eljárva - az Alaptörvény II. cikke és XVI. cikke (4) bekezdése alapján - és ezeket a Nemzeti hitvallással összhangban értelmezve - alkotmányos követelményként megállapítja: a szociális

\footnotetext{
572 21/2013. (VII. 19.) AB határozat [33]

573 35/2014. (XII. 18.) AB határozat [47]

574 3070/2017. (IV. 19.) AB határozat [42]

575 3070/2017. (IV. 19.) AB határozat [44]

576 Alaptörvény
} 
igazgatásról és szociális ellátásokról szóló 1993. évi III. törvény 4. § (1) bekezdése a) pontjának aa) alpontja és a 115 . § (2) bekezdése alapján az intézményfenntartó a személyi térítési díjat úgy köteles megállapitani - ha annak viselésére a 114. § (2) bekezdésének c) pontjában foglalt személy köteles -, hogy a megállapitott téritési dij a kötelezett személy saját szükséges tartását ne veszélyeztesse. "577

A szülőtartás alaptörvényi kötelezettségének értelmezésekor „vetette be” az Alkotmánybíróság az R) cikk harmadik bekezdését, és a Nemzeti Hitvallás megfelelő rendelkezését felhasználva állapított meg alkotmányos követelményt a testület, mellyel méltányossá tette az Alaptörvény szülötartásra vonatkozó rendelkezését.

„A Nemzeti Hitvallás nem fogalmaz meg alapjogot."

Jóval több volt az olyan ügyek száma, ahol nem állapította meg a testület az indítványozó igazát a Nemzeti Hitvallással kapcsolatos érvelésnél. Például a 3160/2013. (VII. 24.) végzésében az Alkotmánybíróság kimondta az illetékmentességgel kapcsolatban, hogy nem lehet közvetlenül alkotmányjogi panaszt alapítani a Nemzeti Hitvallásba foglaltak megsértésére hivatkozva. ${ }^{578}$

A 3074/2015. (IV. 23.) AB végzés szerint a Nemzeti Hitvallás és az R) cikk tartalma nem alapjog, hanem ,az Alaptörvény primátusára, értelmezésére és - a jogszabályokkal együtt - mindenkire kötelezö voltára vonatkozóan tartalmaz rendelkezéseket.", 579

A 3081/2015. (V. 8.) AB határozatban foglaltak alapján érdemi vizsgálat nélkül utasította vissza az indítványozó alkotmányjogi panaszát az Alkotmánybíróság, mivel többek között a Nemzeti Hitvallás bizonyos részeire hivatkozva igyekezett alkotmányjogi érvelését megalapozni, azonban nem ö volt az idézett rendelkezések címzettje. $^{580}$

A 3218/2016. (XI. 14.) AB végzés kimondja egy szerencsejátékkal kapcsolatos ügyben, hogy többek között a „Nemzeti Hitvallás felhívott tételei nem tekinthetők az indítványozó Alaptörvényben biztositott jogának", 581

A 3127/2017. (V. 30.) AB végzés szerint a Nemzeti Hitvallás „az Alkotmánybíróság következetes gyakorlata szerint nem tekinthetö Alaptörvényben biztositott jognak". 582

577 27/2013. (X. 9.) AB határozat Indokolás 1.

578 3160/2013. (VII. 24.) AB végzés [20]

579 3074/2015. (IV. 23.) AB végzés [22]

${ }^{580} 3081 / 2015$. (V. 8.) AB határozat [31]

581 3218/2016. (XI. 14.) AB végzés [14] 
Tehát körülbelül 50 ügyben alkalmazta a Nemzeti Hitvallás különböző részeit az Alkotmánybíróság az ítélkezési gyakorlatában, ám elenyésző azon ügyek száma, ahol sikeresen tudott az indítványozó erre hivatkozni, inkább kivételesnek tekinthető a Nemzeti Hitvallás gondolatainak felhasználása. Vannak azonban olyan részei a preambulumnak, amely esetekben elfogadja a testület az érvelést, utalhatunk itt , $a z$ állam szolgálja polgárait, ügyeiket méltányosan, visszaélés és részrehajlás nélkül intézi" gondolatra.

Ha azt vizsgáljuk, volt-e hivatkozás a Nemzeti Hitvallás történeti részére, netalán a jövő nemzedékekre az Alkotmánybíróság gyakorlatában, a következőket láthatjuk:

\section{„Felelösséget viselünk utódainkért",}

Ez a kijelentés fordul elő leggyakrabban az Alkotmánybíróság gyakorlatában. A 27/2013. (X. 9.) AB határozat a már említett szülőtartással kapcsolatosan említi az utódokért való felelősséget, ugyanis a tartási kötelezettség nem sértheti a tartásra kötelezhető gyermeket a saját utódaival szembeni kötelezettségeit mellőzve.

A 3024/2014. (II. 11.) AB végzés esetében egy szélerőmű lebontása kapcsán hivatkoztak az indítványozók fenti rendelkezésre, mivel úgy vélték, hogy a megújuló energiaforrás hozzájárul a fenntartható fejlődéshez, ami a szomszédaikat érő zajhatás miatt a pihenéshez való joggal került kollízióba. Végül az utóbbi került ki győztesen. ${ }^{583}$ A 3024/2015. (II. 9.) határozatában az Alkotmánybíróság a tankönyvpiac szükítése miatti panasz ügyében említi a vizsgált alkotmányos rendelkezések között a fenti részét a Nemzeti Hitvallásnak, csak az érvelésnél nem fejtett ki ehhez kapcsolódóan gondolatmenetet.

A 16/2015. (VI. 5.) AB határozat esetében az indítványozó a köztársasági elnök volt, aki közjogi érvénytelenséget vélt felfedezni az állami földvagyonról szóló törvényekben. Az Alkotmánybíróság ebben az esetben a Nemzeti Hitvallás vonatkozó részét más alaptörvényi elemekkel együtt arra használta, hogy bizonyítsa, az Alaptörvény kiszélesítette az állam környezetvédelmi felelősségét, ${ }^{584}$ és bizonyos rendelkezések tekintetében megállapította a vizsgált jogszabályhelyek alaptörvényellenességét.

\footnotetext{
582 3127/2017. (V. 30.) AB végzés [19]

583 3024/2014. (II. 11.) AB végzés [2]

${ }^{584}$ 16/2015. (VI. 5.) AB határozat [87]-[91]
} 
„Nem ismerjük el történeti alkotmányunk idegen megszállások miatt bekövetkezett felfüggesztését. Tagadjuk a magyar nemzet és polgárai ellen a nemzetiszocialista és a kommunista diktatúra uralma alatt elkövetett embertelen bünök elévülését." 585

A 3038/2016. (III. 3.) AB határozatban az merült fel kérdésként, hogy korlátozza-e az önkormányzati autonómiát, ha az MTA állapítja meg, hogy a közterületek, intézmények elnevezésekor mely személyek minősülnek XX. századi önkényuralmi politikai rendszerhez tartozóknak. A testület érvelése során felhasználta a Nemzeti Hitvallás vonatkozó részét annak bizonyítására, hogy ezt az önkormányzatoknak figyelembe kell venniük feladataik teljesítése során, és egy ilyen jellegü korlátozás az elnevezések során nem alaptörvény-ellenes. ${ }^{586}$

„Büszkék vagyunk arra, hogy Szent István királyunk ezer évvel ezelött szilárd alapokra helyezte a magyar államot, és hazánkat a keresztény Európa részévé tette. "587

A 6/2013. (III. 1.) AB határozat a lelkiismereti és vallásszabadság jogáról, valamint az egyházak, vallásfelekezetek és vallási közösségek jogállásáról szóló 2011. évi CCVI. törvény több rendelkezését is megsemmisítette alaptörvény-ellenesség miatt, mivel nem biztosította megfelelően a vallásszabadsághoz való jogot. A testület érvelésének meglapozása során felhasználta a fenti Nemzeti Hitvallás-részletet is, többek között annak bizonyítására, hogy az egyházak jelentős szereppel rendelkeznek hosszú idő óta Magyarország történetében. ${ }^{588}$

A minta, amely az eddig meghozott alkotmánybírósági döntésekböl kirajzolódik, korántsem elegendő ahhoz, hogy lezárhassuk a kérdés vizsgálatát. További ügyekre van szükség ahhoz, hogy finomodjon a kép. Annyit kijelenthetünk, hogy már vannak olyan ügyek, amelyekben jelentősége lett a Nemzeti Hitvallás vonatkozó részének, azonban a Nemzeti Hitvallásnak túlzott jelentőséget tulajdonítani nem üdvös, viszont egy értéktérkép iránymutató lehet a beadványt benyújtók számára is.

Látható, hogy a testület visszafogottan bánik ezzel az értelmezési lehetőséggel, minimális esetben alapította erre érvelését, de akkor sem önmagában a Nemzeti Hitvallás valamely részére, hanem más alaptörvényi rendelkezésekkel együtt, ahogy azt

\footnotetext{
585 Magyarország Alaptörvénye (2011. április 25.)

586 3038/2016. (III. 3.) határozat [25]-[26]

${ }^{587}$ Magyarország Alaptörvénye (2011. április 25.)

588 3038/2016. (III. 3.) AB határozat [122]
} 
az R) cikk harmadik bekezdése kötelező erővel meghatározza. Dicséretes a testület önmérséklete és óvatossága ezen a területen, hiszen a Nemzeti Hitvallás rendelkezései lehetőséget biztosíthatnak a további értelmezésre, akár újabb következtetésekre, amelyek „túlgondolása” komoly veszélyekkel járhat.

Az Alkotmánybíróság dönti el, hogy mely rendelkezésnek milyen értelemet és kötőerőt tulajdonít, tehát változhat az eddigi gyakorlat (például mert módosul a testület összetétele, vagy abban az esetben is megtörténhet, ha megváltozik a többség véleménye egy adott kérdésben).

Álláspontom szerint ingoványos terület az Nemzeti Hitvallás szövegének nagymértékü bevonása az alkotmánybírósági értelmezési gyakorlatba, könnyen vezethet arra az eredményre, mint az USA-ban, ahol a pillanatnyi elhatározás és bírósági testületi összetétel eredményeként hol szükítő, hol tágító hatása volt az alkotmányi megfogalmazásnak. ${ }^{589}$ Viszont olyan esetekben, amikor az Alaptörvény valamely rendelkezése méltánytalanságot okozna, vagy hallgat kérdésben, a rendezésben a preambulum rendelkezései segíthetnek, még érveket szolgáltatva az Alkotmánybíróság számára. Ez persze felvetheti az aktivista alkotmánybíráskodás kérdését.

\subsection{A preambulum múltra és jövőre vonatkozó rendelkezéseinek jelentősége - összegzés}

Látható, hogy a preambulumok szerepe komolyabb lehet, mint ami első ránézésre a rendelkezéseknek tulajdonítható. A magyar Alkotmánybíróság vonatkozó gyakorlata azt bizonyítja, hogy bevonható az alkotmányjogi érvelésbe a bevezető, azonban sohasem alkalmas arra, hogy önmagában jogosultság alapját képezze, hanem mindig más alkotmányos elvekkel együtt érvényesülhet az értelmezés során. Óvatosan kell bánni ezekkel a rendelkezésekkel, mert nem fogadható el a jogszükítés vagy a kötelezettségtágítás, illetve a túl tágra nyitott kapu veszélyeket is hordoz magában, ahogy Vörös Imre a történeti alkotmány vívmányaival kapcsolatban megjegyezte, kétélủ fegyver. ${ }^{590}$

Bár egyes álláspontok szerint a preambulum az alkotmány legfontosabb része, ${ }^{591}$ az ilyen kijelentéseket érdemes szimbolikusan kezelni, mivel a preambulum szerepéből fakadóan nem rendelkezik olyan tulajdonságokkal, mint a szöveg „normatív/rendes”

\footnotetext{
${ }^{589}$ VARGA 2010. 221-222. pp.

${ }^{590}$ VÖRÖS 2016a, 53-55. pp.

${ }^{591}$ LEVINSON, SANFORD: Our Undemocratic Constitution. Oxford University Press, 2006. 13. p.
} 
része, ám értéktani jelentőségéből adódóan alkalmas arra, hogy bevonjon olyan szinteket az elemzésbe, amelyet a normaszöveg nem tesz lehetővé, ezzel biztosítva végül a méltányos döntést, ahogy az a szülőtartási ügyben is látható volt.

Az EU tagállamainak alkotmányos bevezetőiben a múltra és jövőre tett utalások is kaphatnak a magyaréhoz hasonló szerepet, ha az alkotmányt értelmező szerv ezt lehetővé teszi számukra: az interpretáció elősegíti az alkotmány stabilitásának erősítését, ha az állampolgárok úgy érzik, méltányos velük szemben az alkotmány, „megvédi” őket. Nagyobb valószínűséggel fogják tisztelni a polgárok a szöveget, melynek eredménye lehet az alkotmány hosszabb ideig való hatályban maradása. Vannak bőven múltra és jövőre utaló rendelkezések, amelyek alkalmasak lehetnek erre a szerepre, ahogy az a vizsgálat alapján látható.

A múltra utaló rendelkezések segíthetik bizonyos jogok magasabb szintü védelmét, hiszen az Alaptörvény R) cikkére gondolva, más országok alkotmánybíróságai is bevonhatják az értelmezésbe akár a preambulum rendelkezéseit is, ezzel is mindeközben elkerülve a desuetudo-t - elösegítve a minél teljesebb körü jogvédelmi tevékenységet, erősítve az alkotmány stabilitását.

A jövőre utaló rendelkezések a jövő generációk jogainak érvényesítésében segíthetnek, mivel alapját képezhetik az ő érdekeikre, jogaikra való hivatkozásnak. Azok az országok, ahol megjelenik ez a gondolat a preambulumban, egy támogató eszközzel rendelkeznek ezen jogok érvényesítésekor, ami az alkotmány stabilitását is védi.

A múltra és a jövőre utaló rendelkezések más európai uniós tagállamok alkotmánypreambulumaiban is elősegíthetik az értelmezést, hiszen ,, a kifosztott polgár számára a preambulum olyan kincsesláda, amelynek kulcsával más rendelkezik”, 592 és ha a kulcs tulajdonosa önmérsékletet tanúsítva, de néha kinyitja a ládát, azzal megerősítheti az alkotmány stabilitását.

A történeti dimenzió azonban nemcsak a preambulum szempontjából nyújthat segítséget az értelmezéshez és a stabilitás vizsgálatához, hanem más, egyedi szempontból is, ahogy az a következő fejezetben bemutatásra kerül.

\footnotetext{
592 AUBERT, JEAN F.: La constitution francaise de 4 octobre 1968 Zeitschrift für Schweizerishes Recht, 1960/1. 44-45. pp.. idézi VARGA 2010, 229. p.
} 


\section{A történeti alkotmány vívmányai az Alaptörvényben}

Az Alaptörvény hatálybalépésével nemcsak új intézmények, hanem új fogalmak is megjelentek a magyar alkotmányos rendszerben. Az egyik ilyen előtérbe került fogalom a történeti alkotmány, ${ }^{593}$ amelynek újbóli felbukkanása hosszú évtizedek után figyelemre méltó kérdéseket vet fel. Vajon a történeti alkotmány vívmányait az Alkotmánybíróság hogyan tudja alkalmazni? Egy másik új fogalom az alkotmányos identitás, ugyanis ez kezd az érdeklődés középpontjába kerülni, miután a lisszaboni szerződés az EU kötelezettségeként emelte az unió elsődleges jogába a nemzeti identitás fogalmát. ${ }^{594}$ A tagállamok pedig éltek ezzel a lehetőséggel, és a nemzeti alkotmánybíróságok egy része elkezdte meghatározni az identitást ${ }^{595}$ a lisszaboni szerződés alkotmányos kartájának értelmezése során. A két fogalom között kapcsolódási pont ott fedezhető fel, hogy adott alkotmányos alapelvek, értékek vagy alapjogok történeti alkotmány vívmányaivá való minősítése már tekinthető-e identitásformáló kérdésnek, amelynek értelmében a történeti alkotmány meghatározott vívmányai és az alkotmányos identitás bizonyos elemei közös halmazt alkotva a bennük foglaltakat védelem alá helyezik. ${ }^{596}$ Ezáltal azon vívmányok, melyek az alkotmányos identitásnak is részét képezik, az alkotmányos védelmi hálót erősítve két oldalról is oltalom alá kerülnének. Ezeket kvázi „örökkévalósági klauzuláknak” is nevezhetjük, hiszen létük nem az alkotmány szövegéhez kötött, ${ }^{597}$ hanem a szokásjogon keresztül

593 A teljesség igénye nélkül: RIXER 2011; ZLINSZKY 2002; SMUK 2013, 286- 287. pp., CSINK FRÖHLICH 2012b, 10-11.pp., SZENTE 2011, 1-13. pp.; ORBÁN 2013, 51-58 pp.., NACSA MÓNIKA: Történeti alkotmányunk vívmányai: az új Alaptörvény egyes rendelkezéseinek jogértelmezései próbája. In: VARGA NORBERT (szerk.): Az új Alaptörvény és a jogélet reformja, Szegedi Jogász Doktorandusz Konferenciák II., Szegedi Tudományegyetem Állam- és Jogtudományi Doktori Iskola Kiadványsorozata, Szeged, 2013. 186-198. pp.; MiLÁNKOVICH - SZENTGÁLI-TÓTH 2014, 65-74. pp.; VÖRÖs 2016b, 491508. pp.; VARGA ZS. ANDRÁS: Történeti alkotmányunk vívmányai az Alaptörvény kógens rendelkezésében. Iustum Aeuum Salutare, 2016/4. 83-89. pp.; ZÉTÉNYI ZSOLT: Történeti alkotmányunk esélyei (részlet egy nagyobb tanulmányból). Balaton Akadémia Kiadó, 2015. 25-28. pp.

${ }^{594}$ Lisszaboni szerződés 4. cikk (2) „Az Unió tiszteletben tartja a tagállamoknak a Szerzödések elötti egyenlöségét, valamint nemzeti identitását, amely elválaszthatatlan része azok alapvetö politikai és alkotmányos berendezkedésének, ideértve a regionális és helyi önkormányzatokat is. Tiszteletben tartja az alapvetö állami funkci- ókat, köztük az állam területi integritásának biztosítását, a közrend fenntartását és a nemzeti biztonság védelmét. Így különösen a nemzeti biztonság az egyes tagállamok kizárólagos feladata marad."

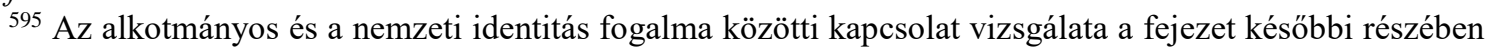
található.

${ }^{596}$ A fejezet az alábbi munka átdolgozott és aktualizált változata: SZAKÁLY 2015, 24-38. pp.

597 Eme funkcióját tekintve ugyanolyan szerepet tölthet be, mint a Sólyom László által kidolgozott láthatatlan alkotmány koncepciója. 
kialakult történeti alkotmány vívmánya „rang”598 elnyerése biztosítja számukra a védelmet.

Az Alaptörvény preambulumában ${ }^{599}$ megjelenik a „történeti alkotmány” és a „történeti alkotmány vívmányai” fogalom is. A „történeti alkotmány vívmányai” fogalom újdonság, a tételes jog az Alaptörvény hatálybalépése előtt nem ismerte. Ugyanakkor a Nemzeti Hitvallásba foglaltak inkább tekinthetők ünnepélyes kinyilatkoztatásnak, mintsem konkrét jogi kötőerővel bíró rendelkezéseknek ${ }^{600}$ - a preambulumok általános jellemzőit figyelembe véve. ${ }^{601}$ Ezt a kérdést a 8 . fejezetben vizsgáltam részletesen. Azonban a kifejezés nemcsak a preambulumban jelenik meg, hanem az Alapvetés R) cikkének (3) bekezdésében is. ${ }^{602}$ A benne foglalt útmutatás szerint az Alaptörvény értelmezésénél figyelembe kell venni, így az Alkotmánybíróságra is ró kötelezettséget, hogy az Alaptörvény erga omnes hatályú értelmezésénél használja a történeti alkotmány vívmányaiban rejlő lehetőségeket. Melyek is ezek a vívmányok? Mi is a történeti alkotmány? Először ezen kérdések vizsgálata szükséges.

\subsection{A történeti alkotmány}

A magyar alkotmányjog tudományában sokáig a magyar önállóság igazolása volt a szerzők célja, elsősorban a történeti érvelés és szemléletmód volt az uralkodó. ${ }^{603}$ Inkább alkotmánytörténeti munkáknak voltak tekinthetők az alkotmányjog tankönyvek egészen Nagy Ernő Magyarország közjoga (Államjog) címü munkájának 1887-es megjelenéséig. ${ }^{604} \mathrm{Az}$ első alkotmányjogi tankönyvek szerzői a magyar függetlenség alátámasztására igyekeztek használni a történeti alkotmány fogalmát, mint például

\footnotetext{
${ }^{598}$ A történeti alkotmány vívmányainak körével, meghatározásukkal és súlyukkal kapcsolatban érdemes megemlíteni Szmodis Jenő elméletét, aki szerint a kifejezetten szabadságjogokkal összefüggő normák alkotják a történeti alkotmány vívmányainak csoportját. SZMODIS JENŐ: Az alkotmány magja és annak védelme. Jogelméleti Szemle, 2013/2. 26. p.

599 Előkérdésként felmerülhet az is, hogy maga a Nemzeti hitvallás mennyire tekinthető klasszikus értelemben vett preambulumnak.

${ }^{600}$ FeJES ZsuZSANNA: Constitutional Identity and Historical Constitution Clause in the Hungarian Fundamental Law and its Effects on Constitutional Interpretation. In: ZOLTÁN SZENTE - FANNI MANDÁK - Zsuzsanna FeJeS (szerk.): Challenges and Pitfalls in the Recent Hungarian Constitutional Development: Discussing the New Fundamental Law of Hungary. Paris: Éditions L'Harmattan, 2015. 2544. pp.

${ }^{601}$ SULYOK - TRÓCSÁNYI 2009, 90-94. pp.

${ }^{602}$ Alapvetés R) cikk „(3) Az Alaptörvény rendelkezéseit azok céljával, a benne foglalt Nemzeti hitvallással és történeti alkotmányunk vívmányaival összhangban kell értelmezni."

${ }^{603}$ BATÓ SZILVIA: Büntetőjogi adalékok a jogbiztonság-fogalom kialakulásához Magyarországon. In: GÁL ISTVÁN LÁsZLÓ (szerk.): Tanulmányok Tóth Mihály professzor 60. születésnapja tiszteletére, Pécs, 2011. 46. p.

${ }^{604}$ JAKAB ANDRÁs: Az alkotmányjog tudománya és oktatása Magyarországon (1990-ig). Jogtörténeti Szemle 2008/2. 61. p.
} 
Virozsil Antal, ${ }^{605}$ aki szerint ,,vannak ezeken kívül még több nagy fontosságu törvények, melyek mind a közállományt érdeklö tartalmuknál, mind különös szentesitvényöknél fogva föfigyelemre méltók. "606 Boncz Ferenc álláspontja szerint

„A magyar alkotmány - mint alább látni fogjuk - nincs egy önálló államokmányba foglalva, hanem évszázadok folyamában fejlödött ki jelen alakjára: (...) azok nem egész tömegükben szolgálnak az alkotmánytan forrásaiul, hanem csak annyiban, amennyiben az államjogi viszonyokat, a kormányzat alakját és a fejedelem országlási jogait tartalmazzák; (...)”607 Ö 46 törvényt sorol a történeti alkotmány részei közé. 608 Ferdinandy Géza meghatározása alapján a magyar alkotmány történeti alkotmány, a honfoglalástól kezdve fejlődött: „Ez magyarázza meg a magyar alkotmány jogforrásainak sokféleségét, az egyes jogelvei értelmezése körül felmerült ellentétek nagy számát, de egyuttal az adja meg a magyar alkotmányjog tudományos tárgyalásának nagy fontosságát és érdekességét, egyuttal ez biztositotta fennmaradását és fejlesztette ki a nemzetnek alkotmánya védelmében rendkívüli szivósságát. "609 Ezután az angol alkotmányt hozza fel a szerző, mint hasonlót, ${ }^{610}$ felhívva a figyelmet a két ország történeti alkotmányának közös pontjaira, amely kérdés nemcsak a századfordulón, hanem napjainkban is érdemes a vizsgálatra. ${ }^{611}$

Nagy Ernő definíciója szerint:

„,Történeti alkotmányoknak nevezzük azokat az alkotmányokat, melyeknek alapja messze a multba, vagy éppen az állam keletkezésére vezethet vissza. (...) De másrészt a történeti alkotmánynak nagy elönye, hogy a nemzet életével szorosan összeforrott. Ezer éves alkotmány átmegy a nép erzületébe, szokásaiba, erkölcseibe, gondolkozásába, ugy, hogy végre az állami életet máskép elképzelni is alig tudja; s mindez fennállását sokkal jobban biztositja, mint bármiféle alkotmányos garantia. "612 A különböző szerzők eltérő meghatározásokat adtak a történeti alkotmány fogalmára, és eltérőek a felsorolásaik is,

\footnotetext{
605 VIROZSIL ANTAL: Magyarország nyilván- vagy közjoga mint az alkotmánya eredetétöl 1847/8-ig fennállott: történelmi szempontból tekintve s röviden elöadva - Budán, Magyar Kir. Egyetemi Nyomda betüivel, 1861. Álláspontja szerint 62 sarkalatos törvény van, és ezeket fel is sorolja. 62-65. pp.

606 VIROZSIL 1861, 65. p.

${ }^{607}$ BONCZ FERENCZ: Magyar államjog, Athenaeum, 1877. 6. p.

${ }^{608}$ BONCZ 1877, 6-18. pp.

609 FERDINANDY GÉZA: Magyarország közjoga (Alkotmányjog). Politzer Zsigmond és Fia, Budapest, 1902., 60. p.

${ }^{610}$ FERDINANDY 1902, 60. p.

611 Vö. pl. SulyoK MÁRTON: The Crystal Ball of Constitution-Making? The Historical Constitution Clause of the Fundamental Law of Hungary and Its Effects on Constitutional Interpretation. 2013. november 26-án az Exeteri Egyetem jogi karán tartott elöadás írásos anyaga, kézirat

${ }^{612}$ NAGY ERNÖ: Magyarország közjoga (Államjog). Athenaeum, 1907. 188. p.
} 
azonban közös pontként tekinthetünk arra, hogy kiemelkedö jelentőséget tulajdonítottak a történeti alkotmánynak és alkotóelemeinek is. A magyar alkotmányfejlődésre 1949-ig a történeti alkotmány volt a jellemző, amíg az 1949. évi XX. törvényt el nem fogadták. Ezzel megszakadt ez a fejlődés, Magyarország alkotmányjoga új útra lépett, más szemléletmóddal, rendszerrel. Ezért nem szerencsés a kettőt egyszerre használni egy rendszerben, mert problémát okozhat az eltérő alap. Mivel Magyarországnak van kartális alkotmánya, a történeti alkotmány mint egész nem használható, valamint figyelembe kell venni azt a tényt is, hogy 1949-ben megszakadt a történeti alkotmány fejlődése. Az Alkotmánybíróság a történeti alkotmány vívmányait 1949-ig vizsgálja. ${ }^{613}$ Ebben nincs is nézeteltérés, ám az 1946. évi I. törvény megítélése már vitás, egyes álláspontok szerint „kisalkotmány”, mások csak az 1949. évi XX. törvényt tekintik alkotmányos erejünek, így kérdésként merülhet fel a történeti alkotmány kontinuitása 1946-1949 között. ${ }^{614}$

Szétfeszítené e munka kereteit, s ezért csak megemlítem a Szent Korona-tant, amely a történeti alkotmányunk fontos eleme. A sajátos magyar szuverenitáselmélet központi jelentőségü volt 1949-ig. A történeti alkotmány vívmányainak Alaptörvénybe kerülésével pedig újra figyelem irányult erre a kérdésre, azonban a Szent Korona-tan sem használható úgy fel, mint 1949 előtt. A történeti alkotmány kérdéskörének „reneszánsza” mellett a jogfolytonosság vizsgálata is új lendületet kapott az új alkotmány értelmezése során, azonban ezt a területet sem segít tisztázni az Alaptörvény. ${ }^{615} \mathrm{Az}$ viszont megállapítható, hogy a jogtörténet gyakran hasznos kútfőnek bizonyult az alkotmányos fejlődés során: „A modern értelemben vett jogfolytonosságnak és a modernizációnak együtt kell érvényesülnie, ami nem jelent mást, mint az alkotmányos hagyományok racionális figyelembevételét.", 616 tehát a jogfolytonosság szempontjából is alátámasztható a történeti alkotmány vívmányainak jelentősége. Mindazonáltal megállapítható, hogy a történeti alkotmány csak egyes részei meghatározásával definiálható, és ebben nincs egységes álláspont, bár kísérletek

\footnotetext{
${ }^{613}$ Ettől eltérő álláspontot képvisel Sólyom László, aki szerint az Alkotmánybíróság eddigi határozatai részét képzik a történeti alkotmány vívmányainak. SóLYOM LÁSZLÓ: Alkotmány és alkotmányos kultúra Magyarországon. http://tte.hu/solyom-laszlo-alkotmany-es-alkotmanyos-kultura-magyarorszagon/

${ }^{614} \mathrm{Az}$ eltérő álláspontokat lásd: HORVÁTH ATTILA: A magyar történeti alkotmány tradiciói. Alkotmánybírósági Szemle, 2011/1. 57. p.

615 SCHWEITZER GÁBOR: Közjogi provizórium, jogfolytonosság, új közjogi irány - Az 1919/1920-1944 közötti magyarországi alkotmányjog-tudomány vázlata, II. rész. Közjogi Szemle, 2014/2. 17-18. pp.

616 VARGA NORBERT: Ideiglenesség és jogfolytonosság - Történeti jogintézmények szerepe a magyar alkotmányozásban. De iurisprudentia et iure publico, V. évf. 2011/2. 12. p.
} 
történtek erre. Kartális alkotmány hiánya esetén valóban jelentős a történeti alkotmány meghatározásának, felhasználásának szerepe, 1949 óta azonban nem ez a kiindulópont. Kartális alkotmány meglétében a „dokumentumnak” van megkérdőjelezhetetlen elsőbbsége, de mi történik, ha a kartális alkotmányba foglalják a történeti alkotmány vívmányainak felhasználási kötelezettségét? Egyes álláspontok szerint ebben az esetben egy sajátos normacsoport jön létre, amelynek tartalmát az alaptörvénybe foglalt rendelkezések határozzák meg, önállóan nem érvényesülhetnek, csak az alaptörvényi rendelkezések értelmezési kereteiként. ${ }^{617}$

\subsection{A történeti alkotmány vívmányainak tartalma}

A történeti alkotmány vívmányai kifejezés értelmezésének kérdése az Alaptörvény hatálybalépése óta fel-felbukkan a magyar jogtudomány köreiben, ${ }^{618}$ főleg az Alkotmánybírósághoz kapcsolódóan, azon fogalmak közt, amelyeket a testület döntésein keresztül kimunkál. Azonban a közösségi jogi szókincsnek régóta része a vívmány kifejezés, de a nemzeti jogban csak a lengyel Lisszabon-döntés és a magyar Alaptörvény említi ennek fontosságát.

A történeti alkotmány vívmányai értelmezésével foglalkozott Vörös Imre, aki nagyon alaposan vizsgálta meg a lehetséges problémákat az értelmezés során. Kimutatta, hogy nem alakult ki egységes vélemény a testületen belül ebben a kérdésben (sem), és nem alakult ki egységes feltételrendszer arra vonatkozóan, hogy miként lehet a történeti alkotmány vívmányának minősíteni valamely rendelkezést. ${ }^{619}$ Bemutatja a történeti alkotmányt vizsgáló szakirodalmat is. ${ }^{620}$ Racionálisan tekinti át a lehetséges problémákat, azonban kissé túlzónak tartom azt a véleményt, mely szerint „, $A$ vívmányok keresése egyre inkább „ötletbörzévé” nemesül, vagyis komolyan veszélyezteti a jogbiztonságot," 621 Ugyanis ha megnézzük az eddigi vívmányokat, azt láthatjuk, hogy nem esett túlzásba az Alkotmánybíróság, nem sok esetben olvasztott ki vívmányt a döntései során, azonban a döntések esetlegessége miatt érthető az aggodalom.

\footnotetext{
${ }^{617}$ Szmodis 2016, 2. p.

618 MILÁNKOVICH ANDRÁS - SZENTGÁLI-TÓTH BOLDIZSÁR: Vívmányok a gyakorlatban. http://www.arsboni.hu/ vivmanyok-a-gyakorlatban.html ${ }^{619}$ VÖRÖS 2016b, 46-48. pp.

${ }^{620}$ VÖRÖS 2016b, 48-50. pp.

${ }^{621}$ VÖRÖS 2016b, 55. p.
} 
Vörös Imre tanulmánya másokat is véleménynyilvánításra sarkallt. Szmodis Jenő felhívta a figyelmet arra, hogy a jogértelmezés többirányú, ezért nem feltétlenül lehet a történeti alkotmány vívmányait sem egyféle módon értelmezni. ${ }^{622}$ Szalma József álláspontja szerint ,az ún. történelmi alkotmányból csupán a sarkalatos törvények „, szelleme” és nem a szava az irányadó. Vagyis ennek a ma is általánosan elfogadható szabályait kell (intencionálisan) figyelembe venni."623 Tehát az intenciót kell figyelembe venni, kollízió esetén az időben későbbinek elsőbbséget adni. ${ }^{624}$ Nincs egységes álláspont a szakirodalomban sem ebben a kérdésben, ahogy az alkotmánybírák között sem.

Már az Alaptörvény hatálybalépése előtt is foglalkozott az Alkotmánybíróság egyes jogintézmények, alapjogok történeti hátterével, felhívva a figyelmet azok fontosságára anélkül, hogy megállapította volna a történeti alkotmány vívmányainak létét. ${ }^{625}$ Ám az Alaptörvény megváltoztatta a képet, és lehetőség nyílt a testület számára a történeti alkotmány vívmányainak kidolgozására. Első ilyen döntésük 2012-ben született, ${ }^{626}$ amely tárgya miatt is nagy érdeklődésre tartott számot (a bírák kényszernyugdíjazása), valamint a benne meghatározott első történeti alkotmány vívmány megállapítás is jelentős lépés volt. ${ }^{627} \mathrm{Az}$ Alkotmánybíróság kimondta, hogy feladata a történeti

${ }^{622}$ SZMODIS 2016, 179-180. pp.

${ }^{623}$ SZABADFALVI JÓZSEF: Szuverenitás-koncepciók a 20. század első felének magyar jogirodalmában. Pro Publico Bono - Magyar Közigazgatás, I. évf., 2013/1. 188. p.

${ }^{624}$ SZALMA 2017, 188. p

${ }^{625}$ 1359/B/1990. AB határozat ABH 1991, 580, 30/1992. (V. 26.) AB határozat ABH 1992, 167, 10/1993. (II. 27.) AB határozat ABH 1993, 105, 2/1994. (I. 14.) AB határozat, ABH 1994, 41, 46/1994. (X. 21.) $\mathrm{AB}$ határozat, $\mathrm{ABH}$ 1994, 260, 1/1995. (II. 8.) $\mathrm{AB}$ határozat, $\mathrm{ABH} 1995,31,4 / 1997$. (I. 22.) $\mathrm{AB}$ határozat, $\mathrm{ABH} 1997,41,27 / 1995$. (V. 15.) $\mathrm{AB}$ határozat, $\mathrm{ABH}$ 1995, 129, 30/1997. (IV. 29.) $\mathrm{AB}$ határozat, ABH 1997, 130, 515/B/1997. AB határozat, ABH 1998, 976, 4/1999. (III. 31.) AB határozat, $\mathrm{ABH} 1999,52,16 / 1998$. (V. 8.) $\mathrm{AB}$ határozat, $\mathrm{ABH} 1998,140,18 / 2000$. (VI. 6.) AB határozat, $\mathrm{ABH}$ 2000, 117, 167/B/2000. AB határozat, ABH 2002, 1113, 31/2001. (VII. 11.) AB határozat, ABH 2001, 258, 2/2002. (I. 25.) AB határozat, $\mathrm{ABH} 2002,41,801 / \mathrm{B} / 2002$. AB határozat, $\mathrm{ABH} 2008,1899,41 / 2003$. (VII. 2.) $\mathrm{AB}$ határozat, $\mathrm{ABH} 2003,430,3 / 2004$. (II. 17.) $\mathrm{AB}$ határozat, $\mathrm{ABH} 2004,48,14 / 2004$. (V. 7.) $\mathrm{AB}$ határozat, $\mathrm{ABH} 2004,241,673 / \mathrm{B} / 2004$. $\mathrm{AB}$ határozat, $\mathrm{ABH} 2006,1064,3 / 2006$. (II. 8.) $\mathrm{AB}$ határozat, $\mathrm{ABH}$ 2006, 65, 12/2006. (IV. 24.) $\mathrm{AB}$ határozat, $\mathrm{ABH} 2006,2234,51 / 2007$. (IX. 15.) $\mathrm{AB}$ határozat, $\mathrm{ABH}$ 2007, 652, 90/2007. (XI. 14.) $\mathrm{AB}$ határozat, $\mathrm{ABH}$ 2007, 750, 32/2008. (III. 12.) $\mathrm{AB}$ határozat, ABH 2008, 325, 131/2008. (XI. 3.) AB határozat, ABH 2008, 1072.

${ }^{626} 33 / 2012$. (VII. 17.) AB határozat

${ }^{627} 33 / 2012$ (VII. 17.) AB határozat „,[74] Új alkotmányunk R) cikk (3) bekezdése szerint „Az Alaptörvény rendelkezéseit azok céljával, a benne foglalt Nemzeti hitvallással és történeti alkotmányunk vívmányaival összhangban kell értelmezni." Ez a szabály nem önmagában a történeti alkotmányt, hanem annak vívmányai jelentöségét hangsúlyozza. Azt, hogy mi tartozik a történeti alkotmányból a vívmányok közé az Alaptörvény alapján, az Alkotmánybiróságnak kell megállapitania. [75] A magyar történeti alkotmány konszolidált értelmezésének minimumához tartozik annak elfogadása, hogy a XIX. században végbement polgári átalakulást konstituáló törvények a történeti alkotmány részét képezik. E törvények teremtették meg - nem jelentéktelen elözmények után - azt a szilárd jogintézményi alapot, amelyre a modern 
alkotmány vívmányainak meghatározása, és két XIX. századi törvény felhasználásával támasztotta alá az első vívmányt, a bírói függetlenséget. ${ }^{628} \mathrm{E}$ döntésével meghatározta a történeti alkotmány vívmányainak felhasználási módját is: a döntést erősíti, de önmagában nem legitimál. ${ }^{629}$ Ezután több határozatban előfordult a történeti alkotmány vívmányai kifejezés, és alkotmányjogi panaszokat is alapoztak erre, több-kevesebb sikerrel. Például a 3244/2014. (X. 3.) AB határozatot indikáló alkotmányjogi panasz is történeti érvekkel igyekszik alátámasztani indoklását. ${ }^{630}$ Emellett más határozatokban maga az Alkotmánybíróság hozott fel történeti érvelést. A 22/2014. (VII. 15.) határozatában az Alkotmánybíróság először röviden áttekintette a távollévő terhelttel szembeni eljárás történeti előzményeit, felhasználva a 1896. évi XXXIII. tc., a Büntető Perrendtartás vonatkozó szabályait és korábbi AB határozatokat [pl. 14/2014. (V. 7.) $\mathrm{AB}$ határozat]. Ez akár úgy is értelmezhető, hogy a történeti vívmányok részét képezik az Alkotmánybíróság korábbi gyakorlatának, ma is felhasználható részei. Ezt az álláspontot képviselte korábban Sólyom László is, aki szerint maguk a határozatok is részét képezik a történeti alkotmány vívmányainak, ${ }^{631}$ azonban ennek az elméletnek ellentmondó álláspontok is nyilvánosságot kaptak. ${ }^{632} \mathrm{Az}$ Alkotmánybíróság továbbra is használja korábbi határozatait, hiába rendelkezett az Alaptörvény negyedik módosítása hatályon kívül helyezésükről. A testület megtalálta azt a módszert, amellyel korábbi

jogállam épül. Amikor tehát az Alaptörvény mintegy ablakot nyit közjogunk történeti dimenziójára, ráirányítja a figyelmet azokra az intézménytörténeti elözményekre, amelyek nélkül mai közjogi viszonyaink és általában jogi kultúránk gyökér nélküliek lennének. Az Alkotmánybíróság felelössége ebben az új helyzetben rendkívüli, mondhatni történelmi: a konkrét ügyek vizsgálatakor kötelezöen be kell emelnie kritikai horizontjába a jogi intézménytörténet releváns forrásait. [76] A jelen ügyben legalább két ilyen történeti kútfö nem kerülhetö meg: az 1869:IV. és az 1871:IX. tc.-ek."

${ }^{628}$ Ezzel az alkotmányozó által megteremtett fogalom az alkotmány értelmezőjének kezében más szerepet kapott, amivel az Alkotmánybíróság „,bombát helyezett el” határozatában, akárcsak a 45/2012 (XII. 29.) határozatában az Alaptörvény posztambulumát felhasználva. Lásd: ORBÁN 2013, 55. p.

${ }^{629}$ CSINK LÓRÁNT: Az Alkotmánybíróság határozata a bírói hivatás felső korhatárának szabályairól - Az elmozdithatatlanság alkotmányjogi fogalma. Jogesetek Magyarázata, 2012/4. 30.

630 „A történeti források arról szólnak, hogy legalábbis az Anjou-kor óta müködtek Magyarországon olyan intézmények, amelyek a modern közjegyzö történelmi elözményei. A hiteles helyek, a közjegyzöi feladatoknak ellátása a távoli történelmi múltban, önmagában is igazolja, hogy Magyarországon a középkortól léteztek intézményi autonómiák. A közjegyzői hivatást a modern magyar jogrendszerbe a királyi közjegyzökröl szóló 1874. évi XXXV. törvénycikk iktatta be. A törvény a hatalommegosztás finom szerkezetébe a mai jogi szabályozáshoz hasonlóan illesztette be a közjegyzö jogintézményét, a miniszteri kinevezéshez, a függetlenség garanciájaként a hatalmi ágakra is tekintö összeférhetetlenségi szabályok (sem képviselöség, sem közhivatal, sem egyéb közszolgálat, sem pedig egyházi tisztség viselése nem volt összeegyeztethetö a közjegyzői tisztséggel, 3.S), továbbá elmozdithatatlanság és a cselekvöképesség megszünéséig, illetve holtig tartó hivatalviselés járult: (...)”

http://public.mkab.hu/dev/dontesek.nsf/0/f6a5c5aa83e6483fc1257be3001b8de8/\$FILE/IV_1198_0_2013

_inditvany_anonim.pdf

${ }^{63} 1$ http://mandiner.hu/cikk/20130207_solyom_az_alkotmanybirak_nem_masolnak_hanem_gondolkodnak

632 POKOL BÉlA: Alkotmánybíráskodás - Szociológiai, politológiai és jogelméleti megközelitésekben. Kairosz Kiadó, 2014. 124-125. pp. 
kánonját beépítheti a gyakorlatba. ${ }^{633}$ A 33/2012. (VII. 17.) AB határozatot követő első döntés, amely ismét a történeti alkotmány vívmányaival foglalkozott, a 45/2012. (XII. 29.) AB határozat volt. Bár maga a döntés más szempontok miatt bír kiemelkedő jelentőséggel (alkotmányellenes alkotmánymódosítás, alkotmánybíróság hatásköre az alkotmánymódosítások felülvizsgálatával kapcsolatosan), ${ }^{634}$ azonban az érvelésében megjelenik az Alkotmánybíróság értelmezési kötelezettsége az R) cikk (3) bekezdésének megfelelően. ${ }^{635}$ Emellett Szívós Mária említi még a történeti alkotmányt különvéleményében, azon érvelésének részeként, hogy miért lehetséges átmeneti időszak egy alkotmány elfogadásakor. Az 1/2013. (I. 7.) AB határozathoz füzött két különvéleményben is megjelennek a történeti alkotmány vívmányai, Balsai István és Lenkovics Barnabás is az értelmezési tartomány egyik elemeként beszél a fogalomról. ${ }^{636} \mathrm{Az}$ ügyben a választási eljárásról szóló, még ki nem hirdetett törvény egyes rendelkezései miatt fordult a köztársasági elnök az Alkotmánybírósághoz. A testület a törvény több rendelkezését is megsemmisítette, például a választói regisztrációra vagy a tömegkommunikációs eszközök választási kampányban való részvételére vonatkozókat. Lenkovics különvéleményében az R) cikk (3) bekezdését mint az értelmezési tartomány részét vázolja fel. Balsai pedig az Alaptörvény hatására megváltozott alkotmányos értékrend alátámasztására használja többek között az Alaptörvény vonatkozó rendelkezéseit.

633 22/2012. (V. 11.) AB határozat „,[41] Az Alkotmánybíróság az egyes hatásköreiben eljárva alkotmányértelmezést végez, (...) Az Alkotmánybíróságnak azokra az alapértékekre, emberi jogokra és szabadságokra, továbbá alkotmányos intézményekre vonatkozó megállapitásai, amelyek az Alaptörvényben nem változtak meg alapvetöen, érvényesek maradnak. Az elözö Alkotmányon alapuló alkotmánybírósági döntésekben kifejtett elvi jelentőségü megállapítások értelemszerüen irányadók az Alaptörvényt értelmezö alkotmánybirósági döntésekben is. Ez azonban nem jelenti az elözö Alkotmányon alapuló határozatokban kifejtettek vizsgálódás nélküli, mechanikus átvételét, hanem az elözö Alkotmány és az Alaptörvény megfelelö szabályainak összevetését és gondos mérlegelést kíván. Ha az összevetésnek az az eredménye, hogy az alkotmányjogi szabályozás változatlan vagy jelentős mértékben hasonló, az átvételnek nincs akadálya. Másrészt az elözö Alkotmány és az Alaptörvény egyes rendelkezései tartalmi egyezösége esetén éppen nem a korábbi alkotmánybírósági döntésben megjelenö jogelvek átvételét, hanem azok figyelmen kívül hagyását kell indokolni." A döntés elemzését lásd: ANTAL ATTILA: Az Alkotmánybíróság határozata korábbi gyakorlatának érvényességéröl - Megdönthetö vélelem az Alkotmányon alapuló gyakorlat mellett, Jogesetek Magyarázata, 2013/2. 3-10. pp.

634 A határozatról részletesen lásd: SzENTE ZOLTÁN: Az Alkotmánybíróság döntése Magyarország Alaptörvényének Atmeneti rendelkezései alkotmányosságáról - Az Alaptörvény integritása és az alkotmányozó hatalom korlátai. Jogesetek Magyarázata, 2013/2. 11-21. pp.

${ }^{635}$ 45/2012. (XII. 29.) AB határozat „,[81] Az Alkotmánybíróság valamennyi, az Alaptörvény 24. cikk (2) bekezdé- sében szabályozott hatáskörét - igy a 24. cikk (2) bekezdés e) pontjában foglalt absztrakt utólagos normakontroll hatáskörét is - az Alaptörvényben foglalt jogállásával és az adott hatáskör rendeltetésével összhangban értelmezi. Az Alaptörvény R) cikk (3) bekezdése értelmében az Alaptörvény rendelkezéseit azok céljával, a benne foglalt Nemzeti hitvallással és történeti alkotmányunk vívmányaival összhangban kell értelmezni."

${ }^{636} 1 / 2013$ (I. 7.) AB határozat 153, 170. 
A 6/2013. (III. 1.) AB határozatban az egyházakra vonatkozó rendelkezések vizsgálatakor a testület kimondta, hogy „(...) az egyházak számára hazánk új demokráciája és alkotmányos rendje kezdetétöl (1990-töl, vö. Nemzeti hitvallás) érvényes, kiemelt önállóságot biztositó, sarkalatos törvényeinkben (Lvt., Ehtv.) rögzített hivatkozott szabályok történeti alkotmányunknak a vallásszabadság terén elért vívmányaival alkotnak szoros egységet, és az Alaptörvény VII. cikk (1)-(2) bekezdésének védelme alatt állnak. ". 637 Tehát ismét egy 19. századi törvényből (1895. évi XLIII. törvénycikk) kiindulva nevezett meg a testület egy újabb elemet a történeti alkotmány vívmányai közül. Lényegében ezzel vált a vallásszabadság, az egyházak önállósága a történeti alkotmány vívmányává.

A 17/20107 (VII. 18.) határozat ismét kimondta, hogy „A vallásszabadság, a vallási türelem a magyar alkotmányos hagyomány része, különösen a felekezeti jogegyenlöség, azaz a különbözö vallású polgárok jogegyenlösége, amely a XIX. század óta történeti alkotmányunk vívmánya. "638

A 21/2013. (VII. 19.) AB határozatban a közérdekü adatok megismeréséhez való joghoz kapcsolódó valódi alkotmányjogi panaszban hivatkoztak a történeti alkotmány vívmányaira. Az Alkotmánybíróság döntése szerint „Az alapjog értelmezéséhez, miután a közérdekü adatok megismeréséhez és terjesztéséhez való jogot az Alkotmány, illetve az Alaptörvény ismerte el, a hagyományos értelemben vett - 1949 elötti - történeti alkotmány nem szolgáltat érdemi szempontokat. "639 A testület tehát elvetette a történeti alkotmány vizsgálatát a közérdekü adatok megismerésének vonatkozásában. A határozat érdekessége, hogy Juhász Imre különvéleményében kifejtett nézetei szerint az Alkotmánybíróság korábbi határozatai a történeti alkotmány vívmányainak tekinthetőek, ${ }^{640}$ ami összecseng Sólyom László véleményével. ${ }^{641}$

${ }^{637}$ 6/2013. (III. 1.) AB határozat [141]

63817/2017. (VII. 18.) AB határozat [39]

${ }^{639}$ 21/2013 (VII. 19.) AB határozat [29]

${ }^{640}$ 21/2013 (VII. 19.) AB határozat [81] „,3. A határozat indokolása (Indokolás [21]) szerint a történeti alkotmányról csak az 1949. évi XX. törvénynyel elfogadott chartális Alkotmány hatálybalépéséig beszélhetünk. Álláspontom szerint azonban az 1989. évi XXXI. törvénnyel módositott, a demokratikus jogállamot megteremtö Alkotmányon alapuló, a negyedik alaptörvény-módositással azonban hatályon kivül helyezett alkotmánybirósági határozatok jelentös részét a törté- neti alkotmány vívmányai közé kell sorolni. Véleményem szerint sem egyértelmü, hogy az 1949-es chartális Alkotmány, illetve annak módositásai a történeti alkotmány (illetve annak vívmányai) közé sorolhatók-e. Az azonban vitathatatlannak tünik számomra, hogy az Alkotmánybiróság 1990 és 2012 között született határozatainak többsége az alkotmányjog (hazai) fejlödése, a demokratikus átmenet, a jogállam kialakulása és megszilárdulása szempontjából jelentös állomásnak tekinthetők. Álláspontom szerint a fenti határozatok a történeti alkotmány vívmányaiként élnek tovább, tekintettel arra a tényre is, hogy 2013. április 1-jével 
A 25/2013. (X. 4.) AB határozatban ismét a bírói függetlenség vetődik fel, mint a történeti alkotmány vívmánya, csak más szempont alapján. Az ügyben ugyanis a bírói pártatlansághoz kapcsolódóan utalt vissza a testület a 33/2012-es döntésébe foglaltakra, azonban nem minősítette a pártatlanságot a történeti alkotmány vívmányává.

A 31/2013. (X. 28.) AB határozat a népszavazáson való részvételi jogot vizsgálta, és ugyan a benyújtott valódi alkotmányjogi panasz megalapozott volt, a népszavazáshoz való jog nem került fel a történeti alkotmány vívmányainak listájára. ${ }^{642} \mathrm{~A}$ testület vizsgálta az R) cikk (3) bekezdésének megfelelően a történeti kontextust is, megállapítva, hogy a népszavazáson való jog nem volt része az 1949 előtti alkotmányos kultúrának, és az 1949-es alkotmány sem biztosította ezt a jogot, az csak később került be az alaptörvénybe.

A 33/2013. (XI. 22.) AB határozat a vádelvvel foglalkozott - többek között -, vizsgálva az intézmény történeti előzményeit anélkül, hogy vívmányt állapított volna meg. A történeti kontextus vizsgálata gyakoriságának növekedése volt megfigyelhető ebben az évben.

A 21/2014. (VII. 15.) AB határozatban ismét a bírói függetlenség kérdése merült fel, mint a történeti alkotmány vívmánya, a befolyásolási kísérletekkel összefüggésben.

A 3015/2014 (II. 11.) alkotmánybírósági végzésben a történeti alkotmány vívmánya a bírói függetlenséghez kapcsolódott, mégpedig a büntetőeljárással kapcsolatban.

A 28/2014. (IX. 29.) AB határozatban ${ }^{643}$ a sajtószabadság történeti alkotmány vívmánya státusza került megerősítésre, a 12 pontra és az áprilisi törvényekre való hivatkozással.

hatályukat vesztették. Megjegyzem, hogy ez az értelmezés nem sérti az írott és történeti alkotmány közötti, a jogtudomány világában kétségtelenül jelen lévő markáns különbségtételt."

${ }^{641}$ „,Tehát az alapjogok és alapvető intézmények tekintetében az alkotmánybíróság érvényesítheti eddigi gyakorlata vívmányait. Ezek voltaképpen történeti alkotmányunk vívmányai közé tartoznak." SóLYOM LÁSzLó: Alkotmány és alkotmányos kultúra Magyarországon. http://tte.hu/solyom-laszlo-alkotmany-esalkotmanyos-kultura-magyarorszagon/

642 31/2013. (X. 28.) AB határozat [25] „Az 1949. évi kommunista alkotmány nem ismerte el alanyi jogként az országos népszavazáson való részvételhez való jogot. E jog az 1994. évi LXI. törvény révén 1994. október 7-töl vált az Alkotmány részévé. Az érintett jog értelmezéséhez, miután az országos népszavazáson való részvételhez való jogot elöször az Alkotmány, illetve az Alaptörvény ismerte el, a hagyományos értelemben vett - 1949 elötti - történeti alkotmány nem szolgáltat érdemi szempontokat." 643 28/2014. (IX. 29.) AB határozat [13] „A sajtószabadság minden kétséget kizáróan történeti alkotmányunk vívmányai közé tartozik. Az 1848-as forradalom legelsö lépése és egyszersmind fö követelése a sajtó szabaddá tétele, a sajtószabadság kivívása volt: a sajtószabadság volt minden más szabadság alapja. E nélkül az égetōvé vált politikai és társadalmi kérdéseket, a nagy átalakulás kívánalmait nem lehetett megfogalmazni a nyilvánosság elött. A március 15-én közzétett ki- áltvány 12 pontja közül a legelső mondta ki: „,Kívánjuk a' sajtó szabadságát, censura eltörlését.” Csak ezt követte a felelös minisztérium, a törvény elötti egyenlöség, a közteherviselés, a jobbágyfelszabadítás követelése és minden egyéb. Az elözetes cenzúra eltörlésével az áprilisi törvények egyike, az 1848. évi XVIII. törvénycikk, a sajtótörvény biztositotta a sajtószabadságot." 
A 29/2014. (IX. 30.) AB határozat ismét kimondta, hogy a közérdekü adatok védelméhez való jog nem képezheti a történeti alkotmány vívmányát. ${ }^{644} \mathrm{Ez}$ a jog ebben a megfogalmazásban a modern demokráciák jellemzője, a második világháború előtt nem merült fel sem a személyes adatok védelmének, sem a közérdekü adatok megismerésének joga. Az akkori technikai fejlettségi szint mellett nem is tudott volna olyan szinten belelátni az állam polgárai életébe, a második világháború után pedig nem merült fel az ehhez hasonló jogok védelme az állammal szemben Magyarországon. Az Alkotmánybíróság tehát meghúzta a vonalat: az 1949 előtt nem releváns jogokkal kapcsolatosan nem lehet történeti alkotmány vívmányát létrehozni/megállapítani.

A 34/2014. (XI. 14.) AB határozatban az erkölcstelen ügylet tilalmáról mondta ki a testület, hogy „európai közös alkotmányos hagyománynak és a magyar történeti alkotmánynak is szerves része, alapvető értéke”. ${ }^{645}$ Azonban a vívmány szót kerülte, vagyis az Alkotmánybíróság nem nyilvánította ki, hogy az erkölcstelen ügylet tilalma a történeti alkotmány vívmánya, csak azt, hogy a történeti alkotmány szerves része. Ezt a két kifejezést tekinthetjük szinonimának? Álláspontom szerint ebben az esetben igen, hiszen az erkölcstelen ügylet tilalma 1949 előtti alapelv, római jogi gyökerekkel, ${ }^{646}$ valamint a magyar tételes jogban jelen volt és van. A vívmány kifejezés jelentése küzdelemmel, hosszú fáradozással elért eredmény, ${ }^{647}$ tehát szerves fejlődés eredménye, azonban attól nem válik valami feltétlenül a történeti alkotmány vívmányává, hogy a történeti alkotmány szerves részét képezi, mivel ebben az esetben túl széles lenne a kör, amely a történeti alkotmány vívmányai közé tartozik. Mindig az Alkotmánybíróság

[14] „A sajtó szabadsága mint történeti alkotmányunk vívmánya kezdettől fogva összekapcsolódott a jelenkor eseményeiröl szóló szabad tájékoztatással, a társadalmi kérdéseknek a nyilvánosság elé tárásával. A sajtó szabadságának védelme, a szabad tájékoztatás feltételeinek biztositása egyrészt az Alaptörvény IX. cikk (2) bekezdésén alapuló állami kötelezettség, másrészt a személyek alapvetö joga, amely az Alaptörvény I. cikk (3) bekezdésében foglalt feltételek mellett korlátozható."

${ }^{644}$ 29/2014. (IX. 30.) AB határozat [43] „Az Alkotmánybíróság továbbra is fenntartja azon álláspontját, miszerint az érintett alapjog értelmezése szempontjából a hagyományos értelemben vett - 1949 elötti történeti alkotmány nem szolgáltat érdemi szempontokat, mivel a közérdekü adatok megismeréséhez és terjesztéséhez való jogok hazánkban elöször az 1989. évi XXXI. törvény tette az Alkotmány részévé."

645 34/2014. (XI. 14.) AB határozat [79]

${ }^{646}$ 34/2014. (XI. 14.) AB határozat [79] „,Az európai civilizáció egyik pilléreként is számon tartott római magánjogból kétezer év óta ismert és bevett a contra bonos mores elve, mely szerint a jóerkölcsbe ütközö jogügylet semmis, ahhoz joghatás nem füzödhet. Az elvet a mintaként is szolgáló francia, osztrák, német magánjogi kódexek törvényi rangra emelték (Code civil Art. 1131. és 1132.; Allgemeines Bürgerliches Gesetzbuch § 878.; Bürgerliches Gesetzbuch § 138.), Magyarországon az első versenytörvény (1923. évi V. törvénycikk 1. §), majd Magyarország Magánjogi Törvényjavaslata (Mtj.) 956. §-a iktatta be (1928ban)."

${ }^{647}$ PuSZTAI FERENC: Magyar értelmező kéziszótár, Akadémiai Kiadó, 2009, 1513. p. 
kompetenciája kimondani, hogy az adott elv a történeti alkotmány vívmányai közé tartozik-e vagy sem.

A 17/2015 (VI. 5.) határozatában az Alkotmánybíróság a földbizottságról állapította meg, hogy a Földforgalmi törvény célja és megoldása ennek vonatkozásában „,történeti alkotmányunk vívmányait is visszatükrözi" ${ }^{648}$ Emellett az ítélet arra is felhívta a figyelmet, hogy „a modern magyar közigazgatási biráskodást létrehozó jogforrás, a magyar királyi közigazgatási bíróságról szóló 1896. évi XXVI. törvénycikk történeti alkotmányunk egyik vívmánya." ${ }^{649}$

A 2/2016 (II. 8) AB határozat kimondta, hogy a bírói hatalomról szóló 1869. évi IV. törvénycikk a történeti alkotmány vívmánya, ${ }^{650}$ amely szétválasztotta a közigazgatást és az igazságszolgáltatást, megteremtette a bírói függetlenséget és a bírói ítélkezés törvény alá rendelését.

A 22/2016 (XII. 5.) AB határozat jelentős lépést tett, amikor meghatározott egy listát a történeti alkotmány vívmányairól példálózó jelleggel: ${ }^{651}$ „a szabadságjogok, $a$ hatalommegosztás, a köztársasági államforma, a közjogi autonómiák tisztelete, a vallásszabadság, a törvényes hatalomgyakorlás, a parlamentarizmus, a jogegyenlöség, a bírói hatalom elismerése, a velünk élö nemzetiségek védelme" ${ }^{652} \mathrm{Ez}$ eddig a legátfogóbb katalógusa történeti alkotmány vívmányainak.

A 12/2017 (VI. 19.) határozatában az Alkotmánybíróság ismét a bírákkal foglalkozott, kimondta, hogy „A magyar történeti alkotmány konszolidált értelmezésének minimumához tartozik annak elfogadása, hogy a XIX. században végbement polgári átalakulást konstituáló törvények a történeti alkotmány részét képezik." ${ }^{653}$ Az 1869. évi IV. törvénycikk vonatkozó részeinek elemzésével bizonyítja a határozat indokolása, hogy ahogy azt már több korábbi határozatában kimondta, a bírói függetlenség és az ebből eredő elmozdíthatatlanság a történeti alkotmány vívmánya. Ebben az esetben a nemzetbiztonsági ellenőrzés szabályait megváltoztató törvényi rendelkezések hoztak volna változást a bírákkal kapcsolatban, azonban a Kúria elnökének indítványára az Alkotmánybíróság alaptörvény-ellenesnek találta a bírósági szolgálati jogviszony

\footnotetext{
648 17/2015. (VI. 5.) AB határozat [54]

649 17/2015. (VI. 5.) AB határozat [87]

650 2/2016. (II. 8.) AB határozat [32]

${ }^{651}$ A határozat egyéb, a téma szempontjából jelentős kérdéseinek vizsgálatára külön kerül sor.

652 22/2016 (XII. 5.) AB határozat [65]

653 12/2017. (VI. 19.) AB határozat [46]
} 
besorolását a nemzetbiztonsági ellenőrzés alá eső foglalkoztatási jogviszonyok közé, valamint egyéb rendelkezéseit is áttekintette a törvénynek.

\subsection{Az alkotmányos identitás}

Az alkotmányos identitás fogalmának vizsgálatát itt csak az EU és a tagállamok közötti vonatkozásban kísérlem meg, ${ }^{654}$ ugyanis a kiterjedt irodalom bemutatása külön tanulmányt igényelne. ${ }^{655} \mathrm{Az}$ EU Bírósága kinyilvánította, hogy a tagállamok nem hivatkozhatnak saját alkotmányos berendezkedésükre annak érdekében, hogy az uniós jogot szelektíven vagy diszkriminatívan alkalmazzák. ${ }^{656}$ Ugyanakkor a Lisszaboni Szerződés 4. cikk (2) bekezdése szerint a tagállamok nemzeti identitása védelmet élvez, mivel az ,elválaszthatatlan része azok alapvető politikai és alkotmányos berendezkedésének, "657 ezáltal kijelölve a határt, amelyet az EU nem léphet át az uniós jog alkalmazása során, védelem alá helyezve azt a részét a nemzeti jognak, amely a nemzeti identitáshoz tartozik, s amely minden tagállam vonatkozásában egyedi tulajdonságokkal rendelkezik. Felmerül a kérdés, mi is az alkotmányos és nemzeti identitás, mi tartozhat azok hatókörébe? Tekinthetjük elsősorban kulturális tartalommal rendelkezőnek (pl. család, házasság), vagy az alkotmány érinthetetlen magjaként, vagy pedig ,azon statikus, materiális, holisztikus elemeket (...) amelyek, mint alkotmányos normák, alapelvek összegészében hatják át az alkotmányt, az alkotmányos rendszert"? ${ }^{658}$ Ezekre a kérdésekre nincs egyértelmű válasz. A fogalmi rendszer nem alakult ki, ${ }^{659}$ azonban ez csak a jéghegy csúcsa, hiszen vizsgálható példának okáért az alkotmányos és nemzeti identitás közötti kapcsolat, vagy a releváns amerikai és az európai jogelméleti álláspontok is ebben a kérdésben, bár ezek között nincs akkora különbség, mint egykor, tekintettel az alkotmányos eszmék migrációjára. ${ }^{660}$

\footnotetext{
${ }^{654}$ Kiemelkedő a Lisszaboni Szerződés jelentősége, lásd: BESSELINK, LEONARD F. M.: Constitutional Identity Before and After Lisbon, Utrecht Law Review, 2010/(6)3. 36-49. pp.

${ }^{655}$ KLUG 2011, 41-49. pp.

${ }^{656}$ Lásd: Flaminio Costa v. E.N.E.L., valamint Internationale Handelsgesellschaft GmbH kontra Einfuhr- und Vorratsstelle für Getreide und Futtermittel.

${ }^{657}$ Lisszaboni Szerződés 4. cikk (2) bekezdés

${ }^{658}$ SULYOK MÁRTON: Nemzeti és alkotmányos identitás a nemzeti alkotmánybiróságok gyakorlatában. In: JAKÓ MIRA ANNA (szerk.): Nemzeti identitás és alkotmányos identitás az Európai Unió és a tagállamok viszonylatában. Nemzetközi és Regionális Tanulmányok 10., Generál, Szeged, 2014. 48-49. pp.

659 SULYOK MÁRTON: Értelem és érzelem vagy büszkeség és balitélet? Alkotmánybiráskodás és alkotmányos identitás. Fontes Juris, 1. évf., 2015/1, 27-39. pp.

${ }^{660}$ Lásd ennek megjelenését bizonyos országok alkotmánybíróságai döntéseiben: HALMAI 2013, 124-168. pp.
} 
Az alkotmányos identitás és a nemzeti identitás fogalmának viszonyát már többen is vizsgálták. Az alábbiakban nem célom minden elmélet részletes bemutatása, csak a fogalmak értelmezése szempontjából néhány releváns gondolat kerül kiemelésre. Trócsányi szerint a fogalmak még tisztázatlanok, ${ }^{661}$ azonban úgy véli, hogy az EU és a tagállamok viszonyában a nemzeti identitás fogalma helyett helyesebb lett volna a tagállami identitás fogalmának használata. ${ }^{662}$ Tribl Norbert szerint a két fogalom a részegész viszonyában áll egymással, , míg a nemzeti identitást hordozó szubjektum a politikai nemzet, az alkotmányos identitás hordozója maga az alkotmányos rendszer”. ${ }^{63}$ A különböző elméletek részletes vizsgálatát teszi meg Drinóczi, arra a következtetésre jutva, hogy „alkotmányos identitás fogalmát mindig visszavezethetjük és leszükithetjük az alkotmány vizsgálatára és értelmezésére". ${ }^{664}$ Nincs tehát egy egységesen elfogadott álláspont a kérdésben, viszont az számomra elfogadható, hogy a két fogalom rész-egész viszonyban van, mert az alkotmányos identitás több a nemzeti identitásnál.

Külön figyelmet érdemelnek az alkotmányos identitás kettősségében rejlö kérdések, hogy hol kardként, hol pajzsként használják, ahogy az szükséges az adott alkotmányos helyzetben a „fegyver” használója szerint. ${ }^{665}$

A definíciós mátrix kusza, és még figyelembe kell venni azt a faktort is, hogy minden tagállam alkotmányos identitása más és más egyedi sajátosságok alapján alakul ki. A tagállami alkotmánybíróságok egy része Lisszabon-határozatokban igyekezett meghatározni azon föbb elemeket, amelyek ebbe a körbe tartoznak. ${ }^{666}$ Azonban nem minden ország döntött ezen út mellett, például a francia gyakorlat inkább jogtechnikai kérdésként kezeli ezt a fogalmat. A kép teljessé tételéhez azonban elengedhetetlen a Lisszaboni Szerződés 2. cikkének beemelése az elemzésbe, ${ }^{667}$ ugyanis a közös európai

\footnotetext{
661 TRÓCSÁNYI 2014, 73. p.

662 TRÓCSÁNYI 2014, 77. p.

${ }^{663}$ TRIBL NORBERT: Az alkotmányos identitás fogalomrendszere jogelméleti megközelitésben. (megjelenés alatt) 8.p.

${ }^{664}$ DRINÓCZI 2016b 34. p.

665 Részletesen lásd: CHRONOWSKI NÓRA: Jogállamiság válságban? Helyzetkép az Európai Unió látószögéből. megjelenés alatt az ELTE ÁJK 350 - Jubileumi tanulmányok, ELTE Eötvös Kiadó, 2018, 68. pp.

${ }^{666}$ Azonban figyelembe kell venni a vizsgálódás során, hogy a lisszaboni szerződés végső értelmezője az Európai Unió Bírósága.

667 Lisszaboni Szerződés 2. cikk „Az Unió az emberi méltóság tiszteletben tartása, a szabadság, a demokrácia, az egyenlöség, a jogállamiság, valamint az emberi jogok-ideértve a kisebbségekhez tartozó személyek jogait - tiszteletben tartásának értékein alapul. Ezek az értékek közösek a tagállamokban, a pluralizmus, a megkülönböztetés tilalma, a tolerancia, az igazságosság, a szolidaritás, valamint a nök és a férfiak közötti egyenlöség társadalmában."
} 
alkotmányos hagyományok részben lefedhetik egy ország alkotmányos identitásának védelmét, hiszen nem feltétlenül olyan elemek képezik egy ország alkotmányos identitásának részét, amelyek kizárólag nemzeti szinten élveznek védelmet, hanem akár regionális, akár nemzetközi szinten is oltalom alá kerülhettek. Először Trócsányi László hívta fel a figyelmet a kérdés fontosságára a 143/2010. (VII. 14.) AB határozathoz füzött párhuzamos indokolásában. ${ }^{668} \mathrm{~A}$ kérdés érzékeny, hiszen a szuverenitás értelmezése dönti el, hol a határ az uniós jog elsőbbségének vonatkozásában, és mi az a mag, amelyet a tagállam szuverenitása körében teljes körüen megőrizhet. ${ }^{669}$ A tagállamok eltérően reagálnak ebben a helyzetben, nemcsak attól függően, hogy milyen régen tagjai az EU-nak. ${ }^{670}$ Magyarország tekintetében kiindulópontként az Alaptörvény rendelkezéseit kell vizsgálni. Az Alapvetés E) cikke foglalkozik Magyarország és az EU viszonyával. ${ }^{671}$ Magyarország szuverenitása gyakorlásának egy részét megosztotta az EU-val, azonban ez nem jelentheti a szuverenitás feladását. Ezzel párhuzamosan az Alaptörvény ideológiai szempontból új elemekkel gazdagította a magyar rendszert és a szimbolikus, nemzeti egységre törekvő rendelkezések jelentősége megnőtt, a Nemzeti Hitvallás kinyilatkoztatásai is ezt a képet erősítik. A nemzetfogalomra is hatással voltak a változások, ebben a tekintetben is történtek/történnek változások, bár maga az Alaptörvény sem segíti elő a fogalmi tisztázást. ${ }^{672}$ Azonban az Alaptörvényben megjelenő új szemléletmód jó alapja lehet a nemzeti identitás meghatározásának, főleg a preambulumban. ${ }^{673}$

Az Alaptörvény tervezett hetedik módosításának szövege tartalmazott olyan kitételt, amely megjelenítette volna az alkotmányos identitás fogalmát, ${ }^{674}$ emellett a „történeti

\footnotetext{
668 „A tagállamok megtartották alkotmányuk azon alapelvei feletti szabad rendelkezési jogukat, amelyek nélkülözhetetlenek az államiság, az alkotmányos identitás fenntartásához."

${ }^{669}$ Az alkotmányos identitás fogalmáról részletesen lásd: DRINÓCZI 2016b, 1-42. pp.

${ }^{670}$ SULYOK 2015, 27-39. pp.

671 Magyarország Alaptörvénye (2011. április 25.) E) cikk „(1) Magyarország az európai népek szabadságának, jólétének és biztonságának kiteljesedése érdekében közremüködik az európai egység megteremtésében. (2) Magyarország az Európai Unióban tagállamként való részvétele érdekében nemzetközi szerzödés alapján - az alapitó szerződésekből fakadó jogok gyakorlásához és kötelezettségek teljesitéséhez szükséges mértékig - az Alaptörvényböl eredö egyes hatásköreit a többi tagállammal közösen, az Európai Unió intézményei útján gyakorolhatja. (3) Az Európai Unió joga - a (2) bekezdés keretei között - megállapithat általánosan kötelezö magatartási szabályt. (4) A (2) bekezdés szerinti nemzetközi szerzödés kötelezö hatályának elismerésére adott felhatalmazáshoz az országgyülési képviselök kétharmadának szavazata szükséges."

${ }^{672}$ SMUK 2013, 261-270. pp.

673 TRÓCSÁNYI 2014, 73. p.

${ }^{674}$ Magyarország Alaptörvényének hetedik módosítása 3. cikk „,Az Alaptörvény R) cikke a következ ő (4) bekezdéssel egészül ki : „(4) Magyarország alkotmányos identitásának védelme az állam minden szervének kötelessége." http://www.parlament.hu/irom40/12458/12458.pdf
} 
alkotmányban gyökerező alkotmányos önazonosságunk" is megjelent a szövegben. ${ }^{675}$ Azonban a valódi előrelépés a kérdésben az Alkotmánybíróság 22/2016 (XII. 5.) határozatával történt, amely megvizsgálta a kérdést a magyar helyzetre vonatkoztatva, amelynek részletes vizsgálata a későbbiekben következik.

\subsection{Lehetséges kapcsolódási pont az alkotmányos identitás és a történeti alkotmány vívmányai között}

Vajon az alkotmányos identitás része a történeti alkotmány vívmányainak kapcsolódási pontként, amelyen keresztül egy nemzet identitása egyfajta módon kifejezést nyerhet ${ }^{676}$ A történeti alkotmány rugalmassága ellenére kiindulópont lehet egy állam számára, hiszen évszázadok alatt alakult ki a tartalma, biztosítva egyfajta időtlenséget a jogi konfliktusoknak, valamint az igazságosságába vetett hitnek. ${ }^{677} \mathrm{Az}$ Alkotmánybíróság számára is hasznos lehet a történeti nézőpont:

„Mivel egy adott tagállam alkotmányos identitása nem egy adott időpillanatban keletkezik, valamivel szemben megerösitve azt - hiszen ez pusztán a már létezö identitás exponálását jelentené egy diskurzusban. Így természetes, hogy a historizáló nézöpont sokat segithet abban, hogy egy nemzeti alkotmánybíróság meghatározhassa, mit is tekint alkotmányos identitása szempontjából - egy befelé forduló és az organikus alkotmányfejlödésre koncentráló „önvizsgálat” szempontjából - döntö jelentőségünek. "678

Azonban Magyarországon 1949 óta kartális alkotmány van, ${ }^{679}$ és egy országban a kettő szupremáciája nem érvényesülhet egyszerre. Mindazonáltal az Alaptörvény szimbolikus kinyilatkoztatásai megerősítették a történeti szempont jelentőségét, különös tekintettel az R) cikk (3) bekezdésére. Az Alkotmánybíróság el is kezdte meghatározni a történeti alkotmány vívmányait. Ezek a vívmányok vajon alkalmasak arra, hogy az európai uniós jog elsőbbségével szemben védjék Magyarország alkotmányos identitását? Az is

\footnotetext{
675 Magyarország Alaptörvényének hetedik cikk http://www.parlament.hu/irom40/12458/12458.pdf

${ }^{676}$ Az alkotmányos identitás és a nemzeti identitás közötti különbség vizsgálatához lásd: TRIBL NORBERT: Az alkotmányos identitás természetének vizsgálata: a nemzeti és európai alkotmányos identitás,.XXXII. OTDK, Budapest, 2015. április 1. 33-35. pp.

677 BALOGH ELEMÉR: Az Aranybulla helye a magyar alkotmánytörténetben. In: LAJOS BESENYEI - GÉZA Érszegi - PedrazZA Gorlero, MAurizio (szerk.): De Bulla Aurea Andreae II. Regis Hungariae MCCXXII, Edizioni Valdonega, Verona, 1999. 63. p.

${ }^{678}$ SULYOK 2015, 27-39. pp.

${ }^{679}$ Vagy 1946 óta, vitás kérdés.
} 
figyelembe veendő, hogy ezeket a vívmányokat maga az EU is védi, hiszen a közös európai alkotmányos örökség részét képezi több olyan érték is, amelyek elengedhetetlen elemei minden tagállam müködésének, mint például a jogállamiság vagy az emberi méltóság védelme. Ezek áthatják egészében a magyar alkotmányos rendszert? Rendelkeznek valamely kulturális sajátossággal? Részét képezik az alkotmány érinthetetlen magvának?

Ha az „érinthetetlen mag” jellemzők szerint vizsgálódunk, akkor érdemes figyelembe venni a Német Szövetségi Alkotmánybíróság meghatározását a nemzeti identitásra vonatkozóan, amely a védett „mag” részének tekinti az örökkévalósági klauzulákat. A Német Szövetségi Alkotmánybíróság az örökkévalósági klauzulákat a nemzeti identitás szerves részének tekinti, akárcsak a történeti alkotmány eddig meghatározott vívmányait. Tekinthetjük-e a történeti alkotmány vívmányait kvázi magyar örökkévalósági klauzuláknak, hiszen szerepüket ahhoz lehet hasonlítani. Úgy vélem, ez lehetséges, hiszen valóban hasonló feladattal rendelkeznek, bár az egyik csoport tételesen az alkotmány részét képezi, a másik csoport kimunkálása pedig Alaptörvénybe foglalt feladata a magyar Alkotmánybíróságnak. Nincsenek konkrét örökkévalósági klauzulák a magyar Alaptörvényben, azonban a történeti alkotmány vívmányai - értékés alapelvi tartalmukon keresztül - segíthetnek körülhatárolni az alkotmányos identitást. Talán ez az értelmezés lehetne a történeti alkotmány vívmányainak az alkotmánybírósági gyakorlaton túlmutató jelentősége, hiszen az alkotmányos identitás megőrzésének jelentősége a szuverenitás őrzéséhez kapcsolható, mivel a tagállamok őrködnek szuverenitásuk felett, igyekeznek azt megvédeni a fogyatkozástól. ${ }^{680} \mathrm{Az}$ alkotmány stabilitása szempontjából is hasznosak lehetnek ezek az „örökkévalósági klauzulák", hiszen a rugalmasság és a merevség közötti megfelelő egyensúly létrehozása az ideális egy alkotmány számára, bár egy alkotmány ideálisságának megítélésénél mindig tekintettel kell lenni az ország sajátosságaira, a történelmi helyzetre. ${ }^{681}$

Az Alkotmánybíróság 2016 végén vizsgálta azt a kérdést, hogy hol húzódnak az állami szuverenitás határai, amelyeket az EU sem léphet át.

680 Ezzel ellentétes a posztszuverenitás elmélete, megjelenését a magyar jogirodalomban lásd: SZABADFALVI 2013, 57-67. pp.

${ }^{681}$ Magyarország vonatkozásában azt is elképzelhetőnek tartom, hogy lenne helye valódi örökkévalósági klauzuláknak, akár a történeti alkotmány vívmányai, akár az alkotmányos identitás elemei néven, hogy az alkotmányos rendszer legfontosabb elemei kitüntetett védelem alá kerüljenek akár külső, akár belső változásokkal szemben. 
A 22/2016. (XII. 5.) AB határozat az alapvető jogok biztosának indítványára született. A biztos az Alaptörvény XIV. cikk (1) bekezdésének és az E) cikk (2) bekezdésének értelmezését kérte a következőkkel kapcsolatban:

- a külföldiek csoportos kiutasítására vonatkozó feltétlen tilalom végrehajtása

- „(...) a magyar állami szervek és intézmények jogosultak-e, illetve kötelesek-e az Európai Unióban megvalósuló államközi együttmüködés keretei között olyan intézkedések végrehajtására, amely ellentétes az Alaptörvény rendelkezéseivel, és mely jogintézmény jogosult ennek kimondására, továbbá az alapító szerzödésekhez kapcsolódó hatáskörgyakorlás korlátozhatja-e olyan jogi aktus végrehajtását, amely nem alapul az EU részére átadott hatáskörön. "682

- milyen módon korlátozhatják az értelmezendő rendelkezések Magyarország szuverenitását a kérdésekkel kapcsolatban.

Az Alkotmánybíróság a kérdésben már állást foglalt tagállami Alkotmány-/Legfelső Bíróságok gyakorlatának vizsgálata után arra a következtetésre jutott, hogy az EU jogi aktusainak eredményeként nem sérülhet a szuverenitás, valamint az alkotmányos önazonosság sem. Tehát bár az alapjogi biztos nem kapott választ konkrét kérdéseire, most először alaposan megvizsgálta a kérdést az Alkotmánybíróság, amely „,(...) egy régi adóssága a magyar Alkotmánybíróságnak, és a mostani határozat egy nagy lépést tesz az emlitett felsorakozás felé”, ${ }^{683}$ amikor megállapította hatáskörét az ügyben. A határozat számos izgalmas kérdést vet fel, ${ }^{684}$ azonban jelen munka csak a történeti alkotmány vívmányaival összefüggő kérdésekre koncentrál.

E szerint a döntés megállapította, hogy

„Magyarország alkotmányos önazonossága nem statikus és zárt értékek jegyzéke, ugyanakkor több olyan fontos összetevöje kiemelhetö példálódzó jelleggel, amelyek azonosak a ma általánosan elfogadott alkotmányos értékekkel: a szabadságjogok, a hatalommegosztás, a köztársasági államforma, a közjogi autonómiák tisztelete, a vallásszabadság, a törvényes hatalomgyakorlás, a parlamentarizmus, a jogegyenlöség, a bírói hatalom elismerése, a velünk élö nemzetiségek védelme. Egyebek mellett ezek

682 22/2016 (XII. 5.) AB határozat (az indítvány lényege)

683 22/2016 (XII. 5.) AB határozat [89]

${ }^{684}$ Például a magyar jog és az uniós jog korántsem ellentmondásmentes viszonyát, lásd: BLUTMAN 2017, 1-14. pp.; BLUTMAN 2010, 90-99. pp. 
történeti alkotmányunk olyan vívmányai, amelyeken az Alaptörvény és általa a magyar jogrendszer nyugszik. ",685

Tehát kapunk egy katalógust a történeti alkotmány vívmányairól, amelyben ott szerepelnek az eddig konkrétan megállapított vívmányok mellett olyan rendelkezések is, melyek alkotmányos jelentősége megkérdőjelezhetetlen, azonban AB határozat eddig még nem mondta ki vívmány „rangjukat”.

Ahogy azt megállapítottam 2015-ben, ${ }^{686}$ az alkotmányos identitás, vagyis az alkotmányos önazonosság elemeiként megjelenhetnek a történeti alkotmány vívmányai, és elősegíthetik az alkotmány stabilizációjának megerösítését, és metszéspont lehet a két halmaz között.

Bár Stumpf István párhuzamos indokolásában felhívta a figyelmet arra, hogy a történeti dimenzió elengedhetetlen a vizsgálathoz, ${ }^{687}$ nem foglalkozott részletesen a kérdéssel. Varga Zs. András párhuzamos indokolása viszont tartalmaz egy olyan listát a történeti alkotmány vívmányairól, melyben a határozat indokolásában kiemelt vívmányok mellé a történeti alkotmány megfelelő részeit rendeli. ${ }^{688}$

Komoly érdeklődést eredményezett az Alkotmánybíróság ezen döntése, ${ }^{689}$ hiszen ezzel létrejött egy katalógus, mely elöször, bár levezetés és részletes indokolás nélkül, de meghatározza a történeti alkotmány tíz vívmányát.

Részletesen elemzi a döntést Chronowski Nóra és Vincze Attila, arra a következtetésre jutva a történeti alkotmány vívmányainak vonatkozásában, hogy „Ezzel az Alaptörvényben nem szereplö - korláttal az Alkotmánybíróság nagyon széles felhatalmazást ad saját magának a tekintetben, hogy - az Alaptörvény szövegétöl, tartalmától függetlenedve, elszakadva - mi alkotmányos, és mi nem. "690

685 22/2016 (XII. 5.) AB határozat [65]

686 SZAKÁLY 2015, 36-38. pp.

687 22/2016 (XII. 5.) AB határozat [95]

688 22/2016 (XII. 5.) AB határozat [112]

„Ezt a jogi értéket jogszabályok jelenitették meg, azokból ismerhetö fel: szabadságjogok és hatalomkorlátozás (Aranybulla), közjogi autonómiák tisztelete (Tripartitum), vallásszabadság (tordai törvények), törvényes hatalomgyakorlás (Pragmatica Sanctio), parlamentarizmus, jogegyenlöség (1848. évi áprilisi törvények), hatalommegosztás, birói hatalom elismerése, nemzetiségvédelem (a kiegyezés törvényei)."

${ }^{689}$ Lásd például: CHRONOWSKI - VINCZE 2017, 117-132. pp.; DrINÓCZI TímEA: A 22/2016 (XII. 5.) AB határozat: mit (nem) tartalmaz, és mi következik belöle Az identitásvizsgálat és az ultra vires közös hatáskörgyakorlás összehasonlitó elemzésben. MTA Law Working Papers 2017/1, 1-19. pp.; TRIBL NORBERT: Nincsen alkotmány identitás nélkül? A 22/2016 (XII. 5.) AB határozat jelentösége. (megjelenés alatt)

${ }^{690}$ CHRONOWSKI - VINCZE 2017, 128. p. 
Úgy vélik, hogy ezzel a „képlékeny mércével”691 az Alkotmánybíróság egy „új, meglehetösen absztrakt hatáskört értelmezett magának", ${ }^{692}$ amelynek jövöbeli használata még korántsem egyértelmü.

Azonban „, az alkotmányos identitás elméletének megfelelö alkalmazása hasznos lehet azért is, mert lehetövé teszi a múlt és az egyedi jellemzők becsatornázását az alkotmányról szóló döntéshozatalba. Ennek során pedig arra tanit, hogy egyedül a jelen nem szolgál kielégitő iránymutatásul választásainkhoz; ön-azonosságunknak és szabadságunknak nem korlátja, hanem alapja a múlt. "693

Álláspontom szerint pozitívum, hogy az Alkotmánybíróság adott egy listát -igaz, hogy példálózó jelleggel és megfelelő indokolás nélkül- a történeti alkotmány vívmányairól, amely lista a legfontosabb garanciákat is tartalmazza.

Ez a lista a későbbiekben kiegészülhet, és kiemelkedhet az alkotmányos rendelkezések közül, speciális rangba kerülve, quasi örökkévalósági klauzulákként magasabb szintü védelemben részesülve, és egy esetleges későbbi alkotmányozás során akár valódi örökkévalósági klauzulákként is megjelenhetnek egy új alkotmányban a listán szereplő elvek, ha addig megőrzik kiemelt szerepük, amit az Alkotmánybíróság megállapított.

A határozat érvelése nem minden kérdésben ad kimerítő választ, ${ }^{694}$ azonban az eddigi alkotmánybírósági gyakorlathoz képest előremutató, hogy felvállalta a kérdés vizsgálatát. Ha csak a történeti alkotmány megállapított vívmányainak szempontjából vizsgálódunk, érdemes áttekinteni, hogy a megállapított elemek minősülhetnek-e az EU tagállamainak gyakorlata szerint örökkévalósági klauzulának, azaz tartalmaz-e EU-s tagállami alkotmány ilyen tárgyban örökkévalósági klauzulát?

Látható, hogy szinte mindegyik, történeti alkotmány vívmányaként megjelölt elv megjelenik valamely EU-s tagállam alkotmányának örökkévalósági klauzulái között akár konkrétan, akár csak hasonlósági alapon, kivéve a törvényes hatalomgyakorlás és a velünk élő nemzetiségek védelmének elvét. Hogy ez mennyire volt tudatos lépés az Alkotmánybíróság részéről, csak találgatni tudunk, azonban az örökkévalósági klauzulákba foglalt elvek már vizsgált esetlegessége és specialitása miatt - lásd 7. fejezet - nem tekinthető megfelelő alapnak ezek figyelembe vétele, nem tekinthetőek az elvek a közös alkotmányos örökség részének, hiszen a leggyakrabban használt klauzula

\footnotetext{
${ }^{691}$ ChronowsKi - VinCZE 2017, 128. p.

${ }^{692}$ ChronowsKi - VINCZE 2017, 132. p.

${ }^{693}$ CSINK - FRÖHLICH 2016, 28. p.

${ }^{694}$ DRINÓCZI 2017, 10-15. pp.
} 
a köztársasági alapelv, amely a monarchiákban nem tekinthető általánosan elfogadottnak.

Azt mutatja a vizsgálat, hogy nem lehet ezt a két részterületet megfelelő módon összevetni ezen az alapon, azonban mivel mind az örökkévalósági klauzulák, mind a történeti alkotmány vívmányai egy adott ország legfontosabb rendelkezéseit rögzítik, közelítésük az alkotmányos identitáshoz nem elvetendő. Ha magyar quasi örökkévalósági klauzulákként tekintünk a történeti alkotmány vívmányaira, amelyek az alkotmányos identitáshoz, az alkotmányos önazonossághoz kapcsolódó elveket helyeznek magasabb szintű védelem alá, ebben az esetben megállapítható ez a kapcsolat a magyar vonatkozásban, vagyis az Alkotmánybíróság ezzel a listával, amelyek a történeti alkotmány vívmányai tartalmazza, quasi örökkévalósági klauzulákat hozott létre a magyar gyakorlatban.

Ebből korábbi határozataiban már vívmánynak minősítette a testület a vallásszabadságot, a bírói hatalom függetlenségét és a szabadságjogok meghatározott elemeit(sajtószabadság). Az új lista ennél jóval tágabb, az Alkotmánybíróság az állam müködésének legfontosabb alapjait minősítette vívmánnyá, amelyek ennek megfelelően külön kiemelt helyzetbe kerültek, akár új normahierarchia kialakításának alapját is képezhetik.

A vívmánnyá minősített rendelkezések esetlegesek abból a szempontból, hogy pl. míg minden szabadságjog megkapja a védelmet, a vallásszabadság külön kiemelésre került, valamint a hatalommegosztás és ismét külön a bírói hatalom is megjelenik. A közjogi autonómiák tiszteletének ilyen szintű kiemelése pedig újabb kérdéseket vet fel, amelyek vizsgálata már nem e munka tárgya. A megállapított lista azonban felhívja a figyelmet arra, hogy nemcsak a jelen pillanatnak van jelentősége az alkotmány értelmezésekor, hanem a történeti dimenzió figyelembevétele is lehetséges az Alaptörvény rendelkezései szerint. Mi mondható el ebben a kérdésben a jövő dimenziójáról? A következő fejezet tárgya ennek vizsgálata. 


\section{A jövő elkezdődött? Az intergenerációs igazságosság és az alkotmányok stabilitása}

Az alkotmány stabilitásának vizsgálatakor a múlt mellett a jövőre vonatkozó kérdések is támpontot nyújthatnak, ugyanis a jövő generációk érdekeinek megjelenése, azok képviselete egyre több fórumon, illetve dokumentumban bukkan fel mint prioritás nemzetközi, európai és nemzeti szinten is. ${ }^{69}$ Több szervezet kifejezetten ezen érdekeknek képviseletének szenteli tevekénységét. ${ }^{696}$ A kérdés igencsak szerteágazó, hiszen a környezetvédelemtől a gyermekek jogainak védelmén keresztül a fenntartható fejlődésen át számos olyan terület adódik, amely önmagában külön tanulmányokat érdemelne. ${ }^{697}$

A kérdés jelen vizsgálat során az, hogy a mindenkori szuverénnek hatalmában áll-e úgy megváltoztatni az alkotmányt, vagy teljesen új alkotmányt elfogadni, hogy közben megköti a jövő nemzedékek kezét ennek megváltoztatásában.

Hogyan is dönthettek volna olyan kérdésekről 100-200 évvel ezelött, mint a számítógépes adatkezelés szabályai vagy az azonos neműek házasságának elismerése? Pont ezért van szükség egy merev alkotmány mellett olyan eszközökre, melyek segítik azt rugalmassá tenni - ha a szövegét nem is, a mögötte levő értelmezési tartományt igen - annak érdekében, hogy minél tovább hatályban maradhasson, miközben alkalmassá válik arra, hogy több generáció is használja, ha képes alkalmazkodni a változásokhoz. Amennyiben minden generáció képes a saját igényeinek megfelelően formálni az alkotmányt, nagyobb az esélye, hogy az stabillá válik a meglevő kereteken belül. Vagy ha túl rugalmas az alkotmány, akkor fontos, hogy a jövő generációk figyelembe legyenek véve, ne csak a rövid távú érdekek érvényesüljenek, amikor megváltoztatják az alkotmány szövegét.

Az intergenerációs igazságosság elméletére alapozva különböző példákat hozok a jövő generációk érdekeinek képviseletét elősegítő intézményekre, különös tekintettel az Alapvető Jogok Biztosának a jövő nemzedékek érdekeinek védelmét ellátó

\footnotetext{
${ }^{695}$ A fejezet az alábbi munka átdolgozott és aktualizált változata: SZAKÁLY ZSUZSA: Az intergenerációs igazságosság megjelenése alkotmányi szinten. Pro Futuro 2017/2. szám 48-64. pp.

${ }_{696}$ A teljesség igénye nélkül: http://www.intergenerationaljustice.org/, http://www.futurejustice.org/, https://www.worldfuturecouncil.org/

697 NAGY BOLDIZSÁR: Védőbeszéd a jövö nemzedékekért http://ligetmuhely.com/nagy-a-jovonemzedekekert/ Hasonlóan kiemelt vizsgálódási szempont a fenntarthatóság, lásd: JAKAB ANDRÁS: Fenntarthatóság az európai alkotmányjogban, Közjogi Szemle, 2016/3. 1-17. pp.
} 
helyettesének intézményére. Ezzel összefüggésben az alkotmány stabilitását és a jövő nemzedékek érdekeinek kapcsolatát is vizsgálni kell.

\subsection{Az intergenerációs igazságosság}

Központi gondolata, hogy mivel a jelenlegi generáció döntéshozói alakítják ki azokat a körülményeket, amelyek között az eljövendő generációk élni fognak, ezért beleszólást kell biztosítani számukra már most a feltételek kialakításába.

Ha párhuzamba állítjuk a rousseau-i társadalmi szerződés gondolatát azzal, hogy most az alávetés révén erősödő jogkövetelés fedezhető fel, amelynek következtében egyre tágabb körben biztosított alkotmányos és emberi jogok érvényesülése tapasztalható, akár azt is megállíthatjuk, hogy ez a jogok és a társadalmi szerződés gondolatának új generációját is létrehozhatja. ${ }^{698}$

A környezetvédelem területén elterjedt ez az elv, bekerülhet az alkotmányokba, ${ }^{699}$ ha olyan alkotmányt fogad el, esetleg betonoz be a jelenlegi többség, melyet a jövő generáció nem tud megváltoztatni, az kárára válhat a jövőbeli döntéshozóknak és a polgároknak is.

Egyes szerzők szerint már most meg kellene bontani a hatalommegosztás elvének klasszikus hármasát, és negyedik hatalmi ágként beemelni a jövő generációk érdekét, különböző szervezetek képviseletének segítségével. ${ }^{700}$ Tremmel álláspontja szerint ez továbbfejlesztése lenne a klasszikus gondolkodók elméleteinek. Az intergenerációs igazságosság ${ }^{701}$ jelentősége véleménye szerint megnőtt, mivel a gyorsan fejlődő világ sokkal szélesebb körü lehetőségeket biztosít a cselekvésre, hosszabb ideig tartó hatásokkal. Ezek eredményeként sokkal jelentősebb lenne a jelenlegi generáció döntéseinek ráhatása a jövőre nézve, mint például 2-3 évszázaddal ezelőtt. Emiatt megnőtt e jelenlegi generáció felelőssége is a döntésekkel kapcsolatosan. ${ }^{702}$

Beckman szerint erre nincs szükség, mivel inkább azt kellene vizsgálni, hogy kire hat ki a döntés. Aki beletartozik ebbe a körbe, az része a démosznak, tehát ha kihat a jövő

\footnotetext{
${ }^{698}$ Köszönet az ötletért Sulyok Mártonnak.

${ }^{699}$ WOLF, CLARK: Justice and Intergenerational Debt. Intergenerational Justice Review. Vol. 2. 13-17. pp.

700 TREMMEL, JOERG CHET: An extended separation of powers model as the theoretical basis for the representation of future generations. http://www.futurejustice.org/wpcontent/uploads/2013/11/Paper_Future-Branch_Tremmel.pdf

701 Tremmel, Joerg Chet: The "Generational Justice Principle": A Vision for the 21st Century. in: HERrhausen, ALFRED (szerk.): Gesellschaft für internationalen Dialog (Hg.): Generations in conflict, München (Piper Verlag), 2000. 201-220. pp.

702 TREMMEL 2000. 201-220. pp.
} 
generációra is egy döntés, akkor ők is részét képezik. ${ }^{703} \mathrm{Az}$ alkotmány esetében súlyozott ez a kérdés, hiszen általában többgenerációs dokumentumnak készül, különösen pedig a merev alkotmányok esetében bizonyulhat nehézkesnek a modernizáció, persze ez nem ok arra, hogy valódi súlyt kapjanak a jövő generációk érdekei a döntéshozatal során, még alkotmánymódosítási szempontból sem, mivel ha nem lesz megfelelő számukra valamely jogszabály, vagy az alkotmány valamely része, lehetőségükben áll majd azt módosítani. Amennyiben nem tudják módosítani az alkotmányt, mert nincs meg a szükséges támogatottság, az nem azt jelenti, hogy nincs lehetőségük módosítani az alkotmányt, hanem azt, hogy nincsenek meg a megfelelő eszközeik hozzá. Nem az előző generáció teszi lehetetlenné a változtatást, hanem a megfelelő többség hiánya, az pedig az éppen hatalmon levőkön múlik, hogy mekkora többséggel rendelkeznek, milyen kompromisszumokat képesek kötni a cél elérésének érdekében. ${ }^{704}$

Ezzel az iránnyal szembenálló álláspontok is felfedezhetőek, amelyek inkább megkötnék a döntéshozók kezét, más kontextusokban is. Például Antonin Scalia, az USA Legfelső Bíróságának néhai tagja döntései során az alapító atyák eredeti szándékát kereste az alkotmány szövegében. A textualizmusnak vagy originalizmusnak nevezett irányzat szerint az eredeti szándéknak megfelelően kell értelmezni a szöveget, és olyan kérdésekben is az alkotmány elfogadóinak szándékát szükséges keresni, melyek a modern korhoz köthetőek. ${ }^{705}$ Álláspontja szerint az alkotmány célja a változás megakadályozása, ${ }^{706}$ és bár fontos a korábbi generációk tapasztalatának felhasználása, a jól bevált intézmények átvétele, megőrzése, a változások elkerülhetetlenek, és az alkotmányoknak is alkalmazkodni kell a változásokhoz, az elavult, már nem alkalmazható részeket módosítani kell, vagy értelmezéssel új jelentést adni nekik, melyek segítségével alkalmassá válhatnak a gyakorlatban való alkalmazásra. Így nemcsak papírra vetett szavakként, tiszteletre méltó elvekként érvényesülnének, hanem komoly gyakorlati jelentőséggel is bírhatnak. „Az alkotmányok fontos -

703 BeCKMAn, Ludvig: Democracy and Future Generations. Should the Unborn Have a Voice? In: MERle, JeAn-Christophe (szerk.), Spheres of Global Justice Volume 1. Global Challenges to Liberal Democracy. Political Participation, Minorities and Migration, Springer, 2013. 780. p. ${ }^{704}$ BECKMAN 2013, 785.

705 AuERBACH, BRUCE - ReInHARt, Michelle: Antonin Scalia's Constitutional Textualism: The Problem of Justice to Posterity. Intergenerational Justice Review. 1/2012 (12. Jg.) 18. p.

706 Scalia, Antonin: Common-Law Courts in a Civil-Law System: The Role of United States Federal Courts in Interpreting the Constitution and Laws, The Tanner Lectures on Human Values, Delivered at Princeton University March 8 and 9, 1995. http://tannerlectures.utah.edu/_documents/a-toz/s/scalia97.pdf 114. p. 
nélkülözhetetlen - eszközei a politikai intézmények formálásnak és az alkotmányos értékek megörzésének. "707 Ennek a figyelembevételével kettős feladatot állapíthatunk meg az alkotmányok számára: megőrizni az értéket, és formálni azt, ami még nem ideális. Ha mindkét feladatot el tudja látni egy alkotmány, akkor alkalmas arra, hogy elősegítse az intergenerációs igazságosságot is, hiszen minden generáció célja, hogy jobbá tegye az eljövendő generációk számára a rendszert, amelyben él, ám nem annak a módszernek a segítségével, hogy kizárják még az értelmezés megváltoztatásának lehetőségét is.

Ha megnézzük az USA alkotmányának preambulumát, látható, hogy abban említik az eljövendő generációkat: „(...) biztosítsuk a szabadság áldásait magunk és utódaink számára, meghagyjuk és bevezetjük az Amerikai Egyesült Államok jelen alkotmányát." ${ }^{, 708}$ A célja tehát az volt az alapító atyáknak - többek között -, hogy biztosítsák a kivívott jogokat utódaik számára is. Azonban ez nem jelenti azt, hogy meg is kívánták kötni utódaik kezét, hiszen ők is pont úgy értek el eredményeket, hogy túlléptek az őket megelőző generációkat bilincsbe verő korlátokon, és szabadon döntöttek az állami élet minden alapvető kérdéséről, ugyanis „,Egy alkotmánynak elég rugalmasnak kell maradnia ahhoz, hogy alkalmazkodjon a valóság változásaihoz”. 709

Az intergenerációs igazságosságot ellenkező szempontból vizsgálják azok, akik a jövő generációk képviselete helyett azzal a kérdéssel foglalkoznak, hogy az idősebb állampolgárok részvétele a döntéshozatalba nem tekinthetö-e igazságtalannak, mivel ök már nem fogják megérni a hosszú távú változások hatásait. ${ }^{710}$

Philippe van Parjis álláspontja szerint a társadalmak elöregedése komoly igazságtalansághoz vezet, mivel az eljövendő generációk helyzetét egy olyan társadalom határozza meg, ahol egyre idősebb az átlagos szavazó. ${ }^{711}$ Különösen nagy kárt okozhat ez például a hosszú távú környezeti ártalmak és a természeti erőforrások kimerítése tekintetében, ${ }^{712}$ mivel ezek olyan területek, melyek megítélésében a fiatalabb vagy jövendő generációk tekinthetőek mélyebben érintettnek.

\footnotetext{
${ }^{707}$ AUERBACH-REINHART 2012, 20. p.

${ }^{708}$ Az Amerikai Egyesült Államok Alkotmánya, Preambulum

709 TREMMEL 2006, 206. p.

710 VAN PARJIS, PhILIPPE: The Disfranchisement of the Elderly, and Other Attempts to Secure Intergenerational Justice Philosophy and Public Affairs. Vol. 27, No. 4, Autumn, 1998. 292-333. pp.

${ }^{711}$ VAN PARJIS 1998, 296. p.

${ }^{712}$ VAN PARJIS 1998, 295. p.
} 
Van Parjis többféle lehetséges módszert is bemutat ennek a kérdésnek a kezelésére, mint például a nyugdíjkorhatár elérésével a szavazati jog megszüntetése ${ }^{713}$ vagy a kisgyermekes családoknak további szavazatok biztosítása. ${ }^{714}$ Azért tekinti fontosnak ezeket a módszereket, mert úgy véli, hogy a különböző választási szabályok meghatározásával „úgy lehet erősebben biztositani a fiatalabb emberek figyelembe vételét a közjó meghatározásakor, vagy nagyobb súlyt adni azok döntésének, akik könnyebben el tudják képzelni, hogy mit jelent a fiatalabbak vagy a még meg sem születettek fele való tisztességesség. "715 Tehát valóban ez az érvelés is a fiatalok, a jövő generációk nagyobb súlyát igyekszik támogatni, csakhogy érvei az érme másik oldalát mutatják: az elöregedő nyugati társadalmakban a jövő generációk érdekei képviseletének aránytalan háttérbe szorulásával indokolja lépések tételét annak érdekében, hogy az intergenerációs igazságtalanság megszünjön.

Ez az elméleti irány ellentétes a választójog klasszikus alapelveivel, ${ }^{716}$ vagyis az egyenlőség elvével. A választójoggal kapcsolatosan felmerülhet a kérdés, megfelelö-e a választójog klasszikus rendszere napjainkban is? A mai rendszerek kialakulása előtt sem volt egyenlő a választójog, vajon szükséges-e változtatni ahhoz, hogy az igazságosságnak megfeleljen? A plurális választójog gondolata felmerült a dualizmus idején, de nem fogadták el a javaslatot. ${ }^{717}$

Az érem másik oldala a gyermekek választójogának valamilyen módon való biztosítása. Ezeket a módokat részletesen bemutatja Jakab András, ${ }^{718}$ valamint felmerült a magyar közéletben is a gyermekkel rendelkező szülők szavazati jogának bővítése. ${ }^{719}$

Alkotmányjogi szempontból vizsgálva a Brexit, vagyis Nagy-Britannia EU-ból való kiválásáról szóló döntést a népszavazás szoros eredménye határozta meg, a résztvevők $51,9 \%$-a szavazott a kilépés mellett, és $48,1 \%$-a az unióban való maradás mellett. ${ }^{720} \mathrm{~A}$ 18-24 év közöttiek 70\%-a azonban az uniós tagság fenntartása mellett szavazott, míg a

\footnotetext{
${ }^{713}$ VAN PARJIS 1998, 301-306. pp.

${ }^{714}$ VAN PARJIS 1998, 308-314. pp.

715 VAN PARJIS 1998, 323. p.

716 Lásd: HALMAI GÁBOR: Emberi Jogok. Osiris, 2008, 747-757. pp.; TÓTH KÁROLY: Címszavak alkotmányjogi kislexikonhoz. Szeged, 2010, 202-208. p.

${ }^{717}$ Magyar Alkotmánytörténet. (szerk.): MEZEY BARNA Osiris, 2003. 323. p.

718 JAKAB 2016, 3-7. pp.

719 Szülöi szavazati jog érvek pro és kontra http://alkotmany.reblog.hu/szuloiszavazatijog

${ }^{720}$ KIRK, ASHLEY - COLES, MALCOLM - KROL, CHARLOTTE: EU referendum results and maps: Full breakdown and find out how your area voted. http://www.telegraph.co.uk/news/2016/06/23/leave-orremain-eu-referendum-results-and-live-maps/
} 
60 felettiek esetében jelentős többség támogatta a kiválást. ${ }^{721}$ Elgondolkodtató, hogyha a fent említett valamelyik módszert alkalmazták volna az idősebb korosztály szavazati súlyának mérséklésére, más eredmény született volna. A Brexit nagy horderejü döntés, melynek komoly következményei lesznek nemcsak az Egyesült Királyság, hanem egész Európa számára, és a kérdés tulajdonképpen az angol nyugdíjasok szavazataival dőlt el. Azt a kérdést, mely a fiatalok életére lesz jelentős hatással, nem az ö többségük véleménye szerint döntötték el. ${ }^{722}$

Bár a fiatal szavazati joggal rendelkező korosztály nagy része valóban nem támogatta az EU-ból történő kilépést, csak 36\%-uk vett részt a népszavazáson. Ha magasabb lett volna a részvételi arányuk, akár meg is fordíthatták volna a szoros eredményt, nem lehet csak az idősebbek EU-ellenességét okolni az eredményért, hanem figyelembe kell venni a fiatal korosztály érdektelenségét, jövő generációkkal szembeni közömbösségét is. Mondható, hogy ez nem egy fiatalok által meghatározott döntés, azonban ilyen alacsony részvételi arány mellett, mint amit ez a korosztály mutatott, nem jogos a felháborodás. Biztosítsunk tehát nagyobb beleszólást a döntésekbe a fiataloknak, a jövő generációknak akkor is, ha nem élnek a most biztosított döntési lehetőséggel?

Természetesen nem ilyen egyszerü a megoldás, mindenesetre elgondolkodtató, hogy miközben egyre több hang szól a mellett, hogy nagyobb szerep jusson a jövő generációknak a döntéshozatalban, igénylik ezt egyáltalán a jövő generációk tagjai?

\subsection{Előkérdések}

Ahhoz, hogy megállapíthassuk, milyen képviseleti formában jelenhetnek meg a jövő generációk, először azt szükséges megvizsgálni, hogy egyáltalán rendelkezhetnek-e jogokkal a még meg nem született személyek, vagy érdekeik tekinthetőek-e olyan szintűnek, hogy azok jogosultsággá váljanak. ${ }^{723,724}$ Ehhez először a ,jövő generációk”

\footnotetext{
721 Helm, TOBY: Poll reveals young remain voters reduced to tears by Brexit result: http://www.theguardian.com/politics/2016/jul/02/brexit-referendum-voters-survey

722 SHUSTER, SIMON: The UK's Old Decided for the Young in the Brexit Vote http://time.com/4381878/brexit-generation-gap-older-younger-voters/

${ }^{723}$ Egyesek álláspontja szerint ez kizárt, lásd: BECKERMAN, WILFREd: The impossibility of a theory of intergenerational justice. In TREMMEL, JOERG CHET: (szerk.): The Handbook of Intergenerational Justice, Edward Elgar, 2006. 53-71. pp. A fenntarthatóság jövő nemzedékek jogaiként való megjelenését vizsgálja Jakab András, fejt ki ellene érveket., JAKAB 2016, 7. p.

${ }^{724}$ A jövő nemzedékek jogai létezésének lehetőségével foglalkozik: TATTAY SzILÁRD: Képtelen „képes beszéd"? A jövő nemzedékek jogainak képviseletéről. Állam-és Jogtudomány, 2016/3. 108-122.
} 
fogalmát szükséges vizsgálni. Többféle állásponttal is találkozhatunk a szakirodalomban. ${ }^{725}$

Az egyik legmeghatározóbb Edith Brown-Weiss-é, aki a következő elméletet dolgozta ki: a jövő nemzedékek rendelkeznek jogokkal, mégpedig azért, mert bár ez egyes személyek még valóban nem léteznek, de maga a generáció rendelkezik a jogokkal, a többi generációhoz viszonyítva. Véleménye szerint fontos, hogy a jelen generációt ne csak a noblisse oblige vezesse abban, hogy tekintettel legyen a jövő generációkra. ${ }^{726}$ Álláspontja szerint három fő elvet kell figyelembe venni a kérdés vizsgálatakor:

a) megőrizni a természeti és kulturális források sokféleségét;

b) fejleszteni az élet minőségét;

c) méltányos hozzáférést biztosítani a múltbeli generációk örökségéhez a jövő generációk számára. ${ }^{727}$

Laura Westra föleg a gyermekek jogaival foglalkozik egy 2008-as müvében, felhívja a figyelmet arra a problémára, hogy nem lehet pontosan meghatározni az érintett alanyi kört a jövő nemzedékek tekintetében. ${ }^{728}$ Hogyan tudnánk jogokat biztosítani, ha nem tudjuk, kik és mikor lesznek az alanyai? Ezzel szembe tudjuk állítani azt az érvet, hogy bármilyen módon alakulnak a jövő nemzedékek tagjainak tulajdonságai, mindenképpen érdeke a jelen generációnak a lehető legjobb feltételeket kialakítani a jövő nemzedékek számára, mivel ha most teszünk a globális felmelegedés ellen, az mindenképpen hasznos lesz a jövő nemzedékek számára. ${ }^{729}$ Ahogy az is biztos, amennyiben a jelen generáció olyat tesz, amivel hátrányt okozunk a jövő generációknak, az ő életükre kihatással lesz a mi döntésünk. ${ }^{730}$ Egy másik álláspont szerint, ha biztosítunk is jogokat a jövő generációknak, ,akkor is megmaradnak a javak jelen és jövő generációk közötti elosztásának komoly és megoldatlan kérdései”, 731

\footnotetext{
725 DE-SHALIT, AVNER: Why Posterity Matters Environmental policies and future generations. Routlege, 1995. 113-123. pp.

726 BROWN-WEISS, EDITH: Intergenerational Fairness and Rights of Future Generations - Three principles of intergenerational equity form the basis of intergenerational obligations and rights. Generational Justice, 2002/3. 6. p.

${ }^{727}$ BROWN-WEISS, 2002, 6. p.

728 WESTRA, LAURA: Environmental Justice and the Rights of Unborn and Future Generations Law. Environmental Harm and the Right to Health, Earthscan, 2006, 154. p.

729 NOLT, JOHN: Arguments for and against Obligations for Future Generations. http://web.utk.edu/ nolt/courses/346/futurgen.htm

${ }^{730}$ KumAR, RAHUl: Wronging Future People: A Contractualist Proposal. In: GosSERIES, AXEL - MEYER, LUKAS H. (szerk.): Intergenerational Justice, Oxford University Press, 2009. 270. p.

${ }^{731}$ DE-SHALIT 1995, 113. p.
} 
A ,jövő generációk jogai” fogalom használata vált elterjedtté, ennek ellenére kérdéses, hogy valóban rendelkeznek-e klasszikus értelemben vett jogokkal. Jeorg Tremmel bemutatja a különböző lehetséges definiálási módokat, ${ }^{732}$ majd azt állapítja meg, hogy szerencsésebb lenne a „következő generáció” fogalom használata, mert így a jelen gyermekeire is kiterjeszthetővé válna a fogalom, ami több sikeres pert eredményezhetne a gyermekek nevében véleménye szerint. ${ }^{733}$

A hazai szakirodalomban is megjelent a kérdés. Jakab András álláspontja szerint a fenntarthatóság kihívására adható egyik alkotmányos válaszlehetőség a ,jövő nemzedékek jogai" fogalom bevezetése. Felsorakoztatja az érveket a fogalom használata ellen, majd arra a következtetésre jut, hogy nem érdemes a fogalom használatának bevezetése miatt új fogalmi rendszert kidolgozni, hanem másféle alkotmányos megoldások használata lenne indokolt. ${ }^{734}$

Tattay Szilárd az akarat- és érdekelmélet vizsgálatával elemzi a kérdést, ${ }^{735}$ arra a következtetésre jutva, hogy bizonytalan a terület megítélése, és több szerző különböző véleményét bemutatva vázol fel fogalmi keretet. ${ }^{736}$

Külön kérdés a gyermekek jogainak megítélése, amelynek alapos elemzése szétfeszítené e munka kereteit, ${ }^{737}$ itt csak utalok arra a gondolatra, mely szerint a gyermekek testesítik meg a jövő generációk közül az elsőt, ezért érdekeiket kiemelt védelemben kell részesíteni. ${ }^{738}$

Ha ,igazi” jogként tekintünk a jövő generációk jogaira, át kell strukturálni a jogvédelmi rendszert azok védelmének biztosításához. ${ }^{739}$ Amennyiben érdekként jelennek meg, másként kell kezelni öket. Azonban akkor is figyelembe kell venni érdekeik kiemelt védelmét, mivel a jelen generációinak is érdeke, hogy leszármazottaik részére olyan feltételeket teremtsen, melyek nem nehezítik meg/teszik lehetetlenné életüket.

\footnotetext{
732 TREMMEL, JOERG CHET: Establishing intergenerational justice in national constitutions. In: TREMMEL, JOERG CHET (szerk.): The Handbook of Intergenerational Justice, Edward Elgar, 2006. 199-203. pp.

733 TREMMEL 2006, 205-206. p.

${ }^{734}$ JAKAB 2016, 7-8. pp.

735 TATTAY 2016, 111-115. pp.

736 TATTAY 2016, 119-122. pp.

${ }^{737}$ WESTRA 2006, 22-26; 229-255. pp.

738 WESTRA 2006, 22-26. pp.

739 JAKAB 2016, 7-8. pp.
} 
Álláspontom szerint nem lehet a klasszikus értelemben vett jogokként tekinteni a jövő nemzedékek jogaira, azonban szükséges, hogy kiemelt védelemben részesüljenek az érdekek között, annak érdekében, hogy jelentőségük szerint érvényesülhessenek.

Ahogy az ENSZ 2006-os jelentése fogalmaz a jövő generációk jogairól: „Bár nem tudjuk megfelelö biztonsággal megállapitani a jövő generációk pontos szükségleteit és igényeit, azt minimum megtehetjük, hogy két kérdést figyelembe veszünk: csökkenteni az ártalmakat és azt tenni, ami mind a jelen, mint a jövő generációk számára hasznos. "740

Tehát érdemesebb ezt a kérdést abból a szempontból megközelíteni, hogy mit tehetünk annak érdekében, hogy a jövő generációk számára biztosítottak legyenek a megfelelő körülmények? Meddig mehet el a jelen társadalma ennek érdekében? ${ }^{741}$

Az alkotmányos patriotizmus elmélete szerint az alkotmány értékrendjével való azonosulás miatt kérdéses, hogy mi lehet az az értékálló tartalom, amely erősítheti az alkotmány legitimitását a jövő nemzedékek számára. Hogyan kell ezt megfogalmaznia a jelen alkotmányozójának ahhoz, hogy időtálló legyen a dokumentum? ${ }^{742}$

A számos elméleti ${ }^{743}$ érdekellentét közül az egyik a jelenlegi és a jövő generációk közötti érdekellentét, hiszen „A jövő generációk érdekét nem lehet önmagában, az emberiség-méretü, jelenkori szolidaritástól és felelösségtöl elválasztva érvényesíteni." ${ }^{744}$ A másik érdekellentét a különböző eljövendő generációk közötti érdekellentét. ${ }^{745} \mathrm{~A}$ harmadik pedig egy adott generáción belül nyilvánulhat meg, hiszen ahogy a jelenben sincs érdekegyezés a társadalom minden tagja között, erre a jövőben sem lehet számítani. Az ezen érdekek közötti egyensúly megteremtése az alkotmányozó feladata.

Egy másik probléma, hogy a politikai érdekérvényesítés dimenziói eltérhetnek az intergenerációs érdekektől, amelyek jellegükből adódóan hosszú távon, akár több

\footnotetext{
${ }^{740}$ Intergenerational solidarity and the needs of future generations Report of the Secretary-General, https://sustainabledevelopment.un.org/content/documents/2006future.pdf 18 .

${ }^{741}$ Intergenerational solidarity and the needs of future generations Report of the Secretary-General, https://sustainabledevelopment.un.org/content/documents/2006future.pdf-14.

${ }^{742}$ SULYOK 2016, 347. p.

${ }^{743}$ Melyek könnyen valóságosság is válthatnak, lásd Minors Oposa v. Secretary of the Department of Environment and Natural Resources ügy https://goo.gl/bvxGSw

744 SÓLYOM LÁSZLÓ: A jövő nemzedékek jogai és ezek képviselete a jelenben. In: JÁvOR BENEDEK (szerk.): A jövő nemzedékek jogai. kiadja: Védegylet, Rexprint Nyomda, Budapest, 2000. 38. p.

${ }^{745}$, ,Nem tudhatjuk, a negyedik és az ötödik között, vagy az ötödik és a tizedik nemzedék között nem merüle föl hasonló választási szituáció. Ami jó a most következö öt generációnak, lehet végzetes a hatodiknak. S miért lenne minden érdek globális? Ami jó a jövendö szibériai és alaszkai embereknek, katasztrófa lehet Dél-Ázsiában." SóLYOM 2000, 38. p.
} 
generáción átívelve hatnak. Ez hasonló az alkotmány és az „egyszerü” jogszabály közötti különbséghez, mivel az alkotmánynál különösen fontos cél, hogy hosszabb távra határozza meg az adott ország müködésének alapjait, míg egy jogszabály képezheti pillanatnyi politikai prioritások időszaki és változó lenyomatát is. ${ }^{746}$

John Rawls Theory of Justice címü müve foglalkozik a jövő generációk érdekeivel abból a szempontból, hogy milyen módon szükséges a jelen generációnak félretenni forrásokat a jövő generációk számára, hogyan követeli azt az igazságosság. ${ }^{747}$ Álláspontja szerint minden generációnak félre kell raknia tőkét a jövőre nézve, azt azonban nem tartja meghatározhatónak, hogy pontosan milyen mértékünek kell lennie ennek a tartalékolásnak. ${ }^{748}$ Azonban azt is szükséges figyelembe venni Rawls szerint, hogy minden generáció - kivéve az elsőt - csak nyerhet azzal, ha történik tőkehalmozás, hiszen az egyre csak nőni fog, ha minden generáció tesz hozzá. ${ }^{749}$ Rawls felhívja a figyelmet arra, hogy minden generációnak vannak kötelezettségei a többi generációval szemben, és arra kell törekedniük, hogy a fenntartsák és fejlesszék az igazságos intézményeket. ${ }^{750}$

A különböző konfliktusok mellett felmerülhet, hogy mily módon korlátozza/korlátozhatja magát az adott generáció a jövő generáció érdekében. Ezt vizsgálja az alkotmány vonatkozásában Jon Elster, akinek elmélete szerint az alkotmányozó úgy kötteti meg magát, ahogy Odüsszeusz odaköttette magát az árbochoz, hogy ellen tudjon állni a szirének énekének. ${ }^{751}$ Más szerzők is osztják ezt az álláspontot jövő generációkra is kiterjesztve: „A szavazati joggal még nem rendelkezők érdekeit úgy lehet megvédeni, hogy az aktuálisan élök alkotmányos vagy más intézményi korlátokat állitanak önnön mozgásszabadságuk elé. Tisztázzák azokat a határokat,

\footnotetext{
746 „De a nemzedékek közti igazságosság egyik fontos alapelve, hogy nem rakhatunk irracionális terheket a jelenlegi generációk vállára azért, hogy meghatározatlan jövöbeli igényeket elégitsünk ki, miközben a jelenlegi döntések során sincs jogunk kirekeszteni a jövő nemzedékeket a források felhasználásából.” „A nemzedékek közti igazságosság koncepciója mára elfogadottá vált" Edith Brown Weiss-szel, a Georgetown University Law Center professzorával Jávor Benedek beszélget, Fundamentum, 2008/1. 33. p.

${ }^{747}$ Rawls, JoHn: Theory of Justice, Revised Edition. the Belknap Press of Harvard University Press, Cambridge, Massachusetts, 1999. 251-258. pp.

${ }^{748}$ RAWLS 1999, 252-253. pp.

749 RAWLS 1999, 256. p.

750 RAWLS 1999, 258. p.

751 ELSTER 2000, 94. p.
} 
amelyeken túl bizonyos lépéseket nem tesznek, nem tehetnek meg, és hogy a kisértésnek ellen tudjanak állni, elöre akadályokat görditenek maguk elé. "752

Ezzel nemcsak a jövő generációk érdekeit védik, hanem biztosítják az alkotmány stabilitását is, hiszen minél több akadályt gördítenek maguk elé, minél nehezebb módosítani az adott alkotmányt, az annál stabilabbá válik egy bizonyos határig. Ugyanis a túlzott merevség inkább gátolja az ország megfelelő alkotmányos müködését, ha nem alakultak ki megfelelő informális módszerek ennek kezelésére. ${ }^{753}$

Ezzel szemben, ha nem alakul ki megfelelő módszer a valós változások kezelésére, olyan helyzet alakulhat ki, mint Belgiumban; a kifejezetten nehezen módosítható alkotmány képtelen követni a változásokat, és gyakran interregnum alakul ki az egyes kormányok között. ${ }^{754}$

\subsection{Az alkotmány stabilitása és a jövő generációk jogai}

Vajon az amerikai alapító atyák gondolták volna, hogy művük több száz éven át gyakorlatilag változatlan marad, és csak alkotmánykiegészítéseket füznek ahhoz? Minden alkotmány-kodifikátor fejében ott van a gondolat, hogy vajon mennyire lesz maradandó a munkája, kősziklára vagy homokra építi-e az alkotmányt? Vajon több száz év múlva is ez lesz az adott állam müködésének alapja, és nagy tisztelet övezi, mint a máig élő 1814 -es norvég alkotmányt, ${ }^{755}$ vagy hamar eltünik a történelem viharaiban, mint számos francia alkotmány?

Az egyes alkotmányok között számos szempont szerint tehetünk különbséget (elfogadás módja, terjedelem, rugalmasság, tartalom, stb.), azonban vannak olyan alapkérdések, melyek hasonló módon jelennek meg szinte minden alkotmányban például élethez való jog, bírák függetlenségének biztosítása, stb.. Ezek közé sorolja a jövő generációk érdekeinek megjelenítését Haberle, aki szerint: „A nagyfokú eltérés ellenére, mely az alkotmányos államok általános alkotmányozási szokásait a hagyomány és a temperamentum szerint jellemzi, a generációs problémát az alkotmány olyan részének kellene tekinteni, mely jogi »alapját» képezi az államnak és a

752 GÁL RÓBERT IVÁN - GULYÁS ATTILA - MEDGYESI MÁRTON: Intergenerációs alkotmány. Társadalomtudományi Kutató Intézet (TÁRKI) Zrt., Mühelytanulmányok, No. 5., Budapest. 2011. http://docplayer.hu/14313497-Intergeneracios-alkotmany.html 3. p.

${ }^{753}$ LUTZ, 1995b, 356. p.

${ }^{754}$ CDL-AD(2012)010 6. p.; BEHRENDT 2013, 17-18. pp.

${ }^{755}$ BALOGH 2014, 111. p.; OPSAHL 1991-1992, 181-216. pp. 
társadalomnak." ${ }^{756}$ Volt is már olyan francia alkotmány, amely foglalkozott ezzel a kérdéssel. Az 1793-as francia alkotmány a következő rendelkezést tartalmazta: „Egy népnek mindig jogában áll újra megvizsgálni, megreformálni és megváltoztatni alkotmányát. Egy nemzedék nem vetheti alá törvényeinek a jövö nemzedékeket."757 Tehát már itt felmerült annak a kérdése, hogy a jövő generációk kezét nem lehet megkötni, és szemben az amerikai alapító atyák kinyilatkoztatásával, a Robespierre elvei által meghatározott alkotmány foglalkozott a jövőbeni alkotmányozó döntési szabadságának garantálásával.

$\mathrm{Az}$ 1793-as girondista francia alkotmány-tervezet 12 évre zárta volna ki az alkotmány módosítását vagy új alkotmány elfogadását. ${ }^{758}$ Illetve az USA alkotmányát is tekinthetjük olyan alaptörvénynek, melynek megváltoztatása nagyon magas szintü összefogást, az alkotmány elfogadása óta ritkán látott politikai kompromisszumokat követelne meg, és ezáltal tulajdonképpen szinte lehetetlen is a gyakorlatban, ${ }^{759}$ ezért folyamatosan merülnek fel különböző elméletek az alkotmánymódosítási folyamat megváltoztatására. ${ }^{760}$ Például az Electoral College megszüntetése ilyen cél volna, a közvélemény-kutatások szerint évtizedek óta eltörölné a többség a szervezetet, ${ }^{761}$ ám a bonyolult alkotmánymódosítási eljárás nem teszi ezt lehetővé. ${ }^{762}$ A 18 . században kidolgozott alkotmánymódosítási eljárás akkor jó kompromisszumnak bizonyult, azonban manapság inkább kellemetlen eljárás, melynek megváltoztatása igencsak kérdéses. Ez a jelenség tipikus példája a holtkéz-elméletnek, ${ }^{763}$ mert a holtak valóban kijelöltek egy utat a jövő generációk számára, melyről nem tudnak letérni. Nem készülhettek fel olyan kérdések eldöntésére, melyeknek esetleges kialakulását el sem tudták volna képzelni.

\footnotetext{
${ }^{756}$ HABERLE, PETER: A constitutional law for future generations - the 'other' form of the social contract: the generation contract In: TREMMEL, JOERG CHET (szerk.): The Handbook of Intergenerational Justice, Edward Elgar, 2006. 226. p.

${ }^{757}$ Egyetemes Szöveggyüjtemény, 1793-as francia alkotmány, Emberi és Polgári Jogok Nyilatkozata 28. http://jtd.uw.hu/egyetemesszov.html

758 SPARROW, ALEX: Girondin Constitution, http://www.democracyinprinciple.com/blog/articles/girondin-constitution/

759 Ezzel ellentétes álláspontot foglal el Vicki C. Jackson, lásd: JACKSON, VICKI C.: The (myth of un)amendability of the US Constitution and the democratic component of constitutionalism. International Journal of Constitutional Law 2015/3, Vol. 13. 575-605. pp.

${ }^{760}$ Például: EKELI 2007, 94-101. pp.

761 SAAD, LYDIA: Americans Would Swap Electoral College for Popular Vote http://www.gallup.com/poll/150245/Americans-Swap-Electoral-College-Popular-Vote.aspx

${ }^{762}$ VAROL 2014, 450. p.

${ }^{763}$ Lásd például SIEGEL 2009, 1399-1424. pp.; EASTERBROOK 1998, 1119-1126. pp.
} 
A jövő generációk érdekeinek figyelembe vétele az alkotmányozás során általában háttérbe szorul az alkotmányozó generációk érdekeihez képest, hiszen alig láthatóak ezek az érdekek. Tulajdonképpen az alkotmányozás pillanatában élőknek van a legnagyobb beleszólása a döntésekbe. Ahogy azt Jefferson megfogalmazta: „, Ez a fizikai értelemben vett Föld, és minden, ami rajta található, a jelenlegi fizikai értelemben vett benépesítöihez tartozik, az ö generációjuk ideje alatt. Csak nekik áll jogukban dönteni arról, ami csak öket érinti, és meghatározni az erre vonatkozó jogot; és ez a döntés csak a többségük által hozható meg. " ${ }^{764}$ Azonban ez az álláspont azt a sajátosságát nem veszi figyelembe az alkotmánynak, mely szerint ez a jogi dokumentum tipikusan több generációra hat. ${ }^{765,766}$

Ezen az úton tovább haladva: ha egy generáció úgy dönt, hogy megköti a saját kezét egy kérdésben, kiterjesztheti ezt a korlátozást az őt követő generáció(k)ra is? Elegendő, ha csupán megnehezíti az alkotmány módosításának vagy új alkotmány elfogadásának a szabályait, hogy ezzel konzerválja az általa elfogadott alkotmány értékeit? Ezzel vajon már olyan védöhálót fon az alkotmány köré, mely biztosítja annak stabilitását? Vagy ezzel épp azt éri el, hogy az elérhetetlennek tünő módosítás helyett teljesen új rendszerben fog új dokumentum készülni, ezzel jelentősen megrövidítve az adott alkotmány hatályban maradását?

Az a kérdés, hogy a jövő generációk egyetértenek-e a meghatározott döntésekkel, vagy sem, irreleváns abból a szempontból, hogy a jelenlegi döntéshozó nem tudhatja, milyen érdekeket képviselve, az adott gazdasági, társadalmi, politikai környezet nyomásának eleget téve milyen döntést hoz a jövő generáció egy adott kérdésben in concreto. Különböző hatástanulmányok és elemzések segíthetik az erre való felkészülést, de teljes mértékben nem lehet kikövetkeztetni a jövő várható eseményeit. $\mathrm{Az}$, hogy az alkotmányozók igyekeznek figyelembe venni a jövő generációk érdekeit, ${ }^{767}$ nem tekinthető elegendőnek, ha nem tudjuk, mely érdekek mellett lesznek elkötelezettek.

\footnotetext{
764 JEFFERSON 1816.

${ }^{765}$ Lásd magyar Alaptörvény Nemzeti Hitvallás: „,Alaptörvényünk jogrendünk alapja, szövetség a múlt, a jelen és a jövö magyarjai között."

766 „Thus, a constitution is normally drafted and enforced not only according to the demand of the generations living today but also for future ones. In order to enable the people and their representatives to participate in order to handle the 'social change' 'over and over again', also within shorter time units of 15 or 30 years (henceforth probably more), the model of the constitutional state has developed and differentiated appropriate procedures;"

HABERLE 2006, 223-224. pp.

${ }^{767}$ ELSTER 2000, 170. p.
} 
Ahogy Noah Webster megfogalmazta: , csak a kísérlet, hogy örökre szóló alkotmány készüljön, annak feltételezése, hogy jogunk van kontrollálni a jövö generációk véleményét; olyan, mintha azokra vonatkozóan hoznánk törvényt, akik felett olyan kevés hatalmunk van, mint egy ázsiai ország felett."768 Ez a vélemény jól kifejezi a paradox kérdést: fontos, hogy tekintettel legyünk a jövő generációkra, de honnan tudhatnánk, hogy mire figyeljünk, hogy ez majd a jövő generációk érdekeit (is) szolgálja? Nyilvánvaló, hogy az olyan területek vonatkozásában, mint a környezetvédelem, könnyebben megválaszolható kérdés, hiszen ott a cél az épített és természeti környezet megóvása az eljövendő generációk számára, ami egyértelműen előnyös nemcsak a jelenlegi, hanem a jövőbeli lakosság számára is. Ahogy az a magyar Alaptörvényben is olvasható: „A természeti erőforrások, különösen a termöföld, az erdők és a vízkészlet, a biológiai sokféleség, különösen a honos növény- és állatfajok, valamint a kulturális értékek a nemzet közös örökségét képezik, amelynek védelme, fenntartása és a jövő nemzedékek számára való megőrzése az állam és mindenki kötelessége”. 769 Számos más ország alkotmánya is tartalmaz hasonló kitételt. ${ }^{770}$

Emellett az Alaptörvény más vonatkozásokban is foglalkozik a jövő nemzedékek érdekeivel. A Nemzeti Hitvallás tartalmaz a jövő generációk érdekeivel foglalkozó rendelkezéseket, valamint az L) cikk, ${ }^{771}$ áttételesen az N) cikk, ${ }^{772}$ a Q) cikk ${ }^{773}$ és a 38. cikk $^{774}$ is érinti a jövő nemzedékek érdekeinek kérdését.

A környezetvédelem kérdésében tehát valóban egyszerübb választ találni a felvetett problémákra. Mi a helyzet azonban azokkal a területekkel, melyek nem ilyen

\footnotetext{
768 WEBSTER 1787.

${ }^{769}$ Magyarország Alaptörvénye (2011. április 25.) P) cikk (1) bekezdés

${ }^{770}$ A teljesség igénye nélkül: Afganisztán Alkotmánya, 15. cikk „, The states hall be obligated to adopt necessary measures to protect and improve forests as well as the living environment."

Kirgizisztán Alkotmánya, 48. cikk 3. „Everyone should care for the environment, flora and fauna.”

Lengyelország Alkotmánya, Chapter I., Republic 15. Article 5 „, The Republic of Poland shall safeguard the independence and integrity of its territory and ensure the freedoms and rights of persons and citizens, the security of the citizens, safeguard the national heritage and shall ensure the protection of the natural environment pursuant to the principles of sustainable development."

${ }^{771}$ L) cikk ,(1) Magyarország védi a házasság intézményét mint férfi és nő között, önkéntes elhatározás alapján létrejött életközösséget, valamint a családot mint a nemzet fennmaradásának alapját. A családi kapcsolat alapja a házasság, illetve a szülö-gyermek viszony.

(2) Magyarország támogatja a gyermekvállalást.

(3) A családok védelmét sarkalatos törvény szabályozza."

772 „fenntartható költségvetési gazdálkodás"

773 „, az emberiség fenntartható fejlödése érdekében”

774 38. cikk ,,(1) Az állam és a helyi önkormányzatok tulajdona nemzeti vagyon. A nemzeti vagyon kezelésének és védelmének célja a közérdek szolgálata, a közös szükségletek kielégitése és a természeti eröforrások megóvása, valamint a jövö nemzedékek szükségleteinek figyelembevétele. A nemzeti vagyon megörzésének, védelmének és a nemzeti vagyonnal való felelös gazdálkodásnak a követelményeit sarkalatos törvény határozza meg."
} 
egyértelmüek? Hogyan tudná megmondani az alkotmányozó, hogy 20, 40, 60 év múlva milyen lesz a megítélése például az azonos nemüek közötti kapcsolatoknak, vagy a kettős állampolgárságnak, illetve a menekültjogoknak? Másik szempontból: az 1900 körül alkotmányokat írók gondolták volna, hogy pár évtized múlva a nők jogainak megítélése milyen erőteljes változásokon megy keresztül a munkavállalástól a szavazati jogig? Vannak tényezők, melyek tekintetében nem is érdemes jóslatokba bocsátkozni.

Elemzésem további szempontja, hogy stabilabbá teszi-e az alkotmányt, ha figyelembe veszi az intergenerációs igazságosságot. Valóban tartósabbá válhat az alkotmány, ha tekintettel vagyunk a jövő generációk érdekeire? Vagy inkább attól válik stabillá, ha képes alkalmazkodni az adott generáció érdekeihez? Mennyire határozhatja meg egy korábbi generáció a későbbi mozgásterét? Milyen területekre terjedhet ki ez a korlátozás (egészség, sport, honvédelem, stb.)?

Emellett még a financiális kérdések tekintetében jelenik meg több ország jogrendszerében a fenntarthatóság kérdése. Ez a probléma inkább közgazdasági szempontból vet fel kérdéseket, ${ }^{775}$ azonban számos alkotmány tartalmaz a közpénzügyekre vonatkozó rendelkezéseket, többek között a magyar Alaptörvény is. ${ }^{776}$ A financiális stabilitás is kiemelkedő a jövő generációk számára, hiszen a kiegyensúlyozott hosszú távú gazdálkodás képes biztosítani, hogy az adott ország ne kerüljön olyan adósságspirálba, mely a későbbiek során fogja éreztetni negatív hatását.

Kis számban elöfordul olyan alkotmány is, amelyben általánosságban jelenik meg a jövő generációk érdekeinek védelme, például a svájci alkotmányban, melynek preambulumában generálisan szerepel a jövő nemzedékekkel szembeni felelősség fogalma. ${ }^{777}$

Ha megvizsgáljuk a hatályos alkotmányok jövő generációkra vonatkozó rendelkezéseit, ${ }^{778}$ a következő csoportok alakíthatóak ki: preambulumokban való általános említés (preambulum); valamilyen, a jövő generációk érdekeit támogató

Uganda Alkotmánya, 245. „Protection and preservation of the environment Parliament shall, by law, provide for measures intended a. to protect and preserve the environment from abuse, pollution and degradation; $b$. to manage the environment for sustainable development; and c. to promote environmental awareness."

775 Ederer, PeER-SChUller, PhIlIPP-Willms, StePhAN: The Economic Sustainability Indicator In: TREMMEL ,JOERG CHET (szerk.): The Handbook of Intergenerational Justice, Edward Elgar, 2006. 129147. pp.

${ }^{776}$ Alaptörvény: A közpénzek 36-43. cikk

777 Svájc Alkotmánya

778 Összesen 60 ország alkotmányában lelhető fel a „future generations” kifejezés, ezt tekintettem kiindulópontnak. 
intézmény (intézmény); a jövő generációk jogainak elismerése (jog); a jövő generációk említése a környezetvédelemmel kapcsolatosan (környezetvédelem); valamint a jövő generációk gazdasági kérdésekhez kapcsolódó említése (gazdaság). Ha megnézzük a gyakoriságot, a legritkábban használt eset az intézményi, csak Magyarország és Tunézia alkotmánya tartalmaz erre vonatkozó rendelkezést. ${ }^{779}$ Gazdasági kérdésekre vonatkozóan már 5 alkotmány rendelkezik vonatkozó résszel, ${ }^{780}$ míg 6 alkotmány nyilvánítja ki, hogy elismeri a jövő generációk jogait. ${ }^{781}$ Ezek a minták nem tekinthetőek elterjedtnek, a legtöbb állam, mely foglalkozik a jövő generációk kérdésével, a környezetvédelemhez kapcsolódóan említi, tipikusan úgy fogalmazva, hogy meg kell őrizni azt a jövő generációk számára is. 42 ország alkotmánya tartalmaz ilyen rendelkezést. ${ }^{782}$ A másik terület, ahol megjelenhet a jövő generációk fogalma az alkotmányokban, az a preambulum. A preambulumokban tipikusan csak valamely kiegészítésként tünik fel a jövő generáció, ${ }^{783}$ a jelen alkotmányozó jelzi, hogy a jövő generációkra figyelemmel, az ő érdekeiket is szem előtt tartva készült az alkotmány.

A jövő generációk fogalma tehát már megjelent alkotmányos szinten, de jogaik elismerése nagyon szűk körü, a legtöbb ország inkább „felelősséget érez” vagy a jövő nemzedékek érdekeit tartja szem előtt. A jogként való elismerés nem vált általánosan elfogadottá.

Alkotmányba foglalná a jövő generációk érdekeinek védelmét Tremmel, aki a következő alkotmányos kitétellel segítene ezen a problémán:

„(1) Az állam védelmezi az eljövendö generációk érdekeit az alkotmányos rend keretein belül, a törvényhozó hatalmon keresztül, és a megalkotott jogszabályoknak megfelelöen a végrehajtó és igazságszolgáltatási hatalmon keresztül is. ${ }^{784} \mathrm{Ez}$ a rendelkezés elég tágan fogalmaz, de legalább megjelenítené alkotmányos szinten nemcsak a környezet védelmét, a fenntartható fejlődést vagy az emberiség közös örökségét, hanem komplex képet alkotva, általános védőhálóként ügyelne a jövő generációk érdekeinek védelmére, ahogy az intergenerációs igazságosság elmélete.

\footnotetext{
779 Magyarország Alaptörvénye (2011. április 25.) 30. cikk; Tunézia Alkotmánya 129. cikk

${ }^{780}$ Dél-Szudán, Bhután, Magyarország, Kenya, Zimbabwe

${ }^{781}$ Bolívia, Egyiptom, Japán, Malawi, Marokkó, Mozambik

782 Például: Bolívia, Egyiptom, Guyana, Marokkó, Niger, Svédország, Uganda

783 Például: A Burundi Alkotmány preambuluma: „,Tudatában a történelemmel és a jövő generációkkal szembeni felelösségünknek és kötelezettségeinknek”; A moldovai alkotmány preambuluma „Figyelemmel felelösségünkre és kötelezettségeinkre a múlt, jelen és jövő generációival szemben"

784 TREMMEL 2006, 205. p.
} 


\subsection{A jövő generációk érdekeinek védelmének megjelenési formái}

Először 1967-ben került szóba a jövő nemzedékekkel szembeni felelősség nemzetközi szinten, amelynek eredményeként 1970-ben a tengerfenék kincseinek kiaknázására vonatkozó ENSZ-határozatba bekerült az „emberiség közös öröksége”785 kifejezés. Azóta több egyezményben is felfedezhetö, föleg környezetvédelmi kérdések tekintetében, ${ }^{786}$ és célként jelent meg egy olyan főbiztosi intézmény létrehozatala, mely a jövő generációk érdekeit képviseli. ${ }^{787}$

Emellett kiemelkedő a fülöp-szigeteki Legfelső Bíróság azon döntése, melyben elismeri a jövő generációk jogait. A sokat idézett eset az esőerdők felhasználásának kérdése köré épült, a fenntartható fejlődés elveit figyelembe nem vevő fakitermeléssel szemben léptek fel a jövő generációk érdekében. ${ }^{788}$ Ebben az ügyben kiskorúak indítottak eljárást (képviselők útján) a kormány fakitermelési szerződéseinek megsemmisítése érdekében, amelyek kimerítik az ország természeti erőforrásait állításuk szerint, állításukat adatokkal alátámasztva. ${ }^{789}$ Mivel ilyen sebességű felhasználás mellett hamarosan kimerülnek a természeti erőforrások, szükségét érezték fellépni a jövő generációk érdekében, mivel mire felnőttek lesznek/megszületnek, már nem marad az erdőkből. A Legfelső Bíróság megállapította, hogy képviselhetik a meg nem születetteket is az intergenerációs felelősség elvére alapozva: ,,Nem szükséges hangsúlyozni, hogy minden generáció felelös azért, hogy megörizze a kiegyensúlyozott és egészséges ökológia harmóniájának élvezetét a következő generációk számára”. 790 A döntésüket a fülöpszigeteki alkotmány „kiegyensúlyozott és egészséges ökológia”-ához való jogot tartalmazó rendelkezésére alapozták. A döntés, melyhez egy párhuzamos vélemény készült, ${ }^{791}$ kiemelkedő a környezetvédelem és a fenntartható fejlődés kérdésének

\footnotetext{
7852749 (XXV). Declaration of Principles Governing the Sea-Bed and the Ocean Floor, and the Subsoil Thereof, beyond the Limits of National Jurisdiction 1. cikk

${ }^{786}$ Convention Concerning the Protection of the World Cultural and Natural Heritage Adopted by the General Conference at its seventeenth session Paris, 16 november 1972; Report of the United Nations Conference on Environment and Development, (Rio de Janeiro, 3-14 June 1992)

787 The High Commissioner for Future Generations: the Future We Want Center for International, Environmental Law, World Future Council

http://www.worldfuturecouncil.org/inc/uploads/2016/01/WFC_CIEL_2012_High_Commissioner_for_Fut ure_Generations.pdf

${ }^{788}$ Minors Oposa v. Secretary of the Department of Environment and Natural Resources ügy https://goo.gl/bvxGSw

78925 év alatt 53\%-ról 4\%-ra csökkent az erdővel borított területek mérete az országban.

${ }^{790}$ Minors Oposa v. Secretary of the Department of Environment and Natural Resources ügy https://goo.gl/bvxGSw

${ }^{791}$ Feliciano bíró szerint alaposabb vizsgálatot igényel a „kiegyensúlyozott és egészséges ökológia”-ához való jog fogalma, részleteiben szükséges megállapítani elemeit.
} 
szempontjából. Az ügy komoly hírnévre tett szert, de nem lett általános trend ez az irány.

A bangladesi Legfelső Bíróság a Farooque v. Government of Bangladesh-ügyben a légszennyezés korlátozásával kapcsolatban hozott döntést, ${ }^{792}$ amelyben nem a jövő generációk szemszögéből állapította meg az állam felelősségét, hanem a jogalkotás implementációjának hiányosságaiban. Akkor viszont még nem volt a bangladesi alkotmányban környezetvédelmi klauzula, amely viszont most már megtalálható abban. ${ }^{793}$

A Nemzetközi Bíróság a Gabcikovo-Nagymaros ügyben említi először a fenntartható fejlődés fogalmát, de nem biztosít annak kiemelt jogi státuszt, nem foglalkozik a kérdéssel részletesen. ${ }^{794} \mathrm{~A}$ fenntartható fejlődés és a környezetvédelem nemzetközi jogi megítélése már régóta viták tárgyát képzi, azonban a jövő generációk jogainak külön értékelése nem jelenik meg gyakran ebben a vonatkozásban. Ki kell emelni Weeramanrty bíró tevékenységét, aki több különvéleményében is említi a jövő generációkat. A Gabcikovo-Nagymaros ügyben megállapítja, hogy a fenntartható fejlődés a nemzetközi jog része ${ }^{795}$ majd kínai filozófusok gondolatait hívja segítségül annak bemutatásához, hogy a jövő generációk jogainak védelmét szolgálja a környezetvédelemre odafigyelő emberi fejlesztés. ${ }^{796}$ Álláspontja szerint a hagyományos gondolkodásban már rég megjelent ez a mérce, és erre tekintettel kell lennie a jelen esetben is. ${ }^{797}$ A nukleáris fegyverek használatával és az általuk létrehozott fenyegetéssel foglalkozó döntéshez ${ }^{798}$ füzött terjedelmes különvéleményében úgy fogalmaz: „Észre kell venni ebben a kontextusban, hogy a jövö nemzedékek jogai túlléptek azon a szinten,

\footnotetext{
792 Farooque v. Government of Bangladesh https://www.elaw.org/es/content/bangladesh-farooque-vgovernment-bangladesh-wp-891-1994-20010715-industrial-pollution-case (2017 10. 01.)

793 Banglades Alkotmánya 18A. Protection and improvement if environment and biodiversity „The State shall endeavour to protect and improve the environment and to preserve and safeguard the natural resources, bio-diversity, wetlands, forests and wild life for the present and future citizens."

794 TLADI, DIRE: Sustainable development in international law an analysis of key enviro-economic instruments. Pretoria University Law Press, 2007. 96. p.

${ }^{795}$ Dissenting Opinion of Judge Weeramantry Reports of Judgments, Advisory Opinions and Orders Case Concerning the Gabcikovo-Nagymaros Project (Hungary-Slovakia) Judgment of 25 September 1997, 93.

${ }^{796}$ Dissenting Opinion of Judge Weeramantry Reports of Judgments, Advisory Opinions and Orders Case Concerning the Gabcikovo-Nagymaros Project (Hungary-Slovakia) Judgment of 25 September 1997, 106.

${ }^{797}$ Dissenting Opinion of Judge Weeramantry Reports of Judgments, Advisory Opinions and Orders Case Concerning the Gabcikovo-Nagymaros Project (Hungary-Slovakia) Judgment of 25 September 1997, 107.

${ }^{798}$ International Court of Justice Report of Judgments, Advisory Opinions and Orders Legality of the Threat or Use of Nuclear Weapons Advisory Opinion of 8 July 1996
} 
hogy embrió-állapotban levö jognak tekintsük, melyet még nem ismertek el."799 Álláspontja szerint már a nemzetközi egyezmények, bírói döntések és a civilizált nemzetek által elfogadott jogelvek alapján ki lehet ezt mondani. ${ }^{800}$

A magyar Alkotmánybíróság néhány döntésében is megjelenik a jövő nemzedékek jogainak kérdése, azonban nem központi gondolata egyetlen határozatnak sem ezen fogalom vizsgálata eddig még. A legfrissebb kapcsolódó döntésében, a 16/2015 (VI. 5.) határozatában az Alkotmánybíróság az állami földvagyon kezelésével foglalkozó jogszabályok bizonyos rendelkezéseit vizsgálta, és az indokolásban megjelent a jövő nemzedékek érdeke a Nemzeti Hitvallás vonatkozó része és a P) cikk említésével, valamint Juhász Imre párhuzamos indokolásában felhívja arra a figyelmet, hogy változik a környezetvédelmi jog, szükséges a jövő nemzedékek érdekeinek figyelembe vétele. ${ }^{801}$

Több országban is müködnek különböző állami intézmények a jövő generációk érdekeinek érvényesítését elősegítendő. Van, ahol önálló intézmény lát el ilyen feladatot, mint a magyar jövő nemzedékek érdekeinek védelmét ellátó biztoshelyettese ${ }^{802}$ van, ahol országgyüléshez tartozó szerv jár el ezekben az esetekben, mint az új-zélandi környezetvédelemért felelős országgyülési biztos; ${ }^{803}$ van, ahol kormányzati szerv hatáskörébe tartozik ez a feladat, mint az USA-beli Council of Environmental Quality ${ }^{804}$ vagy az Environmental Protection Agency esetében.

A magyar mellett a legtöbbet emlegetett példa az izraeli, ugyanis az országban müködött egy olyan országgyülési bizottság, mely kifejezetten a jövő generációk érdekeinek képviseletével foglalkozott 2001 és 2006 között. Müködésének hivatalos megszünését 2010-ben mondták ki. ${ }^{805}$ A bizottság hatáskörébe tartozott többek között

\footnotetext{
${ }^{799}$ Dissenting Opinion of Judge Weeramantry Threat or Use of Nuclear Weapons 233.

${ }^{800}$ Dissenting Opinion of Judge Weeramantry Threat or Use of Nuclear Weapons 233.

${ }^{801}$ 16/2015 (VI. 5.) AB harározat [146] „Egyrészt már a Nemzeti Hitvallás hetedik fordulata jelzi, hogy Magyarország a fenntartható fejlödés keretei között elkötelezett a Kárpát-medence természeti és épitett környezetének megóvása iránt, tekintettel úgy a jelenkor emberére, mint a jövö nemzedékekre is. Magyarország tehát kiáll a fenntartható fejödés mellett, biztositandó a jövö nemzedékek számára is az egészséges környezetet, ugyanakkor, mivel a környezeti problémák függetlenek az államhatároktól a természet és környezet védelmét globális kérdésként kezeli. Másrészt megváltozott az egészséges környezethez való jogért való felelösség alanyi köre is. Az Alkotmány ugyanis az egészséges környezethez való jogra lényegében mint az állam intézményvédelmi kötelezettségének esszenciájaként tekintett."

${ }^{802} \mathrm{https} / / / w w w . a j b h . h u / j e l e n l e g i-b i z t o s-e s-$

helyettesek;jsessionid=F387B122D9FEFC38ABA3867FB155A4D8

${ }^{803} \mathrm{http} / / / \mathrm{www} . p c e . p a r l i a m e n t . n z / a b o u t-u s /$ the-commissioner

${ }^{804} \mathrm{https} / / / \mathrm{www}$.whitehouse.gov/administration/eop/ceq

${ }^{805}$ TESCHNER, NAAMA: Official Bodies that Deal With the Needs of Future Generations and Sustainable Development - Comparative Review 3. p. https://www.knesset.gov.il/mmm/data/pdf/me03194.pdf
} 
információ gyüjtése minden érintett intézménytöl, valamint más országgyülési bizottságok előtt tárgyalt javaslatok ügyében is megoszthatta véleményét a bizottság. ${ }^{806}$

Új-Zélandon 1987 óta működik a környezetvédelemért felelős országgyülési biztos intézménye. A biztos független, csak a parlamentnek felel, feladata az új-zélandi környezet megóvása, védelme, széles spektrumú vizsgálati lehetőségekkel. ${ }^{807}$

A magyar jövő nemzedékek érdekeinek védelmét ellátó biztoshelyettes intézményének jelentőségét az is mutatja, hogy nemzetközi jogvédelmi körökben is felfigyeltek rá. ${ }^{808,809} \mathrm{~A}$ magyar jövő nemzedékek érdekeinek védelmét ellátó országgyülési biztos feladata 2012. január elsejével került az Alapvető Jogok Biztosa jövő nemzedékek érdekeinek védelmét ellátó biztoshelyettesi pozíció helyébe, hasonlóan a nemzetiségek jogvédelmét ellátó biztos feladatához. ${ }^{810}$ Fő profilja a környezetvédelem, de emellett foglalkozik a jövő generációk érdekeinek egyéb vonatkozásaival is. ${ }^{811}$ Már a biztosi intézmény kialakításakor szóba került a környezetvédelem mellett más érdekek ${ }^{812}$ megjelenítése is. ${ }^{813}$ Nagy várakozással

806 SHOHAM, SHLOMO - LAMAY, NIRA: Commission for Future Generations in the Knesset: lessons learnt. In: TREMMEL, JOERG CHET (szerk.): The Handbook of Intergenerational Justice. Edward Elgar, 2006. 247. p.

807 http://www.pce.parliament.nz/about-us/our-role

808 Guarding our Future How to include future generations in policy making 8, http://www.futurejustice.org/wp-

content/uploads/2013/04/Ombudspersons_for_Future_Generations_Broshure_WFC.pdf;

TESCHNER, 2013, 5. p., JÁVOR BENEDEK: Institutional protection of succeeding generations Ombudsman for Future Generations in Hungary. In: TREMMEL, JOERG CHET (szerk.): The Handbook of Intergenerational Justice, Edward Elgar, 2006. 282. pp.; BECKMAN, LUDVIG - UGGLA, FREDRIK: An Ombudsman for Future Generations: Legitimate and Effective? In: GoNZÁLEZ-RICOY, IÑIGO GOSSERIES, AXEL (szerk.): Institutions for Future Generations, Oxford University Press, 2016. 127, 130. pp.; Models for Protecting the Environment for Future Generations Science and Environmental Health Network The International Human Rights Clinic at Harvard Law School, October 2008, http://www.law.harvard.edu/programs/hrp 17. p.

809 Például az ENSZ-fötitkár „Intergenerational solidarity and the needs of future generations” címü 2013-as jelentése, amely a magyar intézményt is felsorolja a jövő nemzedékek érdekeit védő intézmények rövid listáján. Intergenerational solidarity and the needs of future generations Report of the SecretaryGeneral, https://sustainabledevelopment.un.org/content/documents/2006future.pdf 29-30. pp.

810 ANTAL ATTILA: A jövö nemzedékek érdekei az Alaptörvényben. In: VEREBÉLYi IMRE (szerk.): Az állam és a jog alapvető értékei a változó világban. A Széchenyi István Egyetem Állam- és Jogtudományi Doktori Iskolájának konferenciakötete, Győr, 2012. 13-21. pp.

811 „,Az ENSZ Emberi Jogi Föbiztosának Hivatala (OHCHR) független szakértöt kért föl az emberi jogok érvényesülése, érvényesitése és a környezetvédelem közötti kapcsolat feltárására, valamint arra, hogy milyen intézményi megoldások segithetik a jó gyakorlatok kialakitását. A független szakértö által összehívott, a kormányok, állami és civil szervezetek képviselöinek részvételével Genfben tartott konzultáción a szószóló munkatársa felhivta a figyelmet a magyar modellre, a nemzeti intézmények együttmüködésére épülö nemzetközi hálózat növekvő jelentöségére." Beszámoló az alapvetö jogok biztosának és helyetteseinek tevékenységéröl 2014, 265. p.

${ }^{812}$ Tipikus területek, melyek kiemelten kezeltek több országban: gyermekjogok, fogyatékkal élők jogai.

${ }^{813}$ „Ezért a koncepció kidolgozói inkább arról beszélnek, hogy a jövő nemzedékek választási szabadságát kivánják biztositani; azt, hogy ök dönthessenek majd arról, mi a jó számukra. Ehhez pedig az életfeltételek diverzitásának hosszú távú garantálásán - szükebb értelemben a környezetvédelmen - 
tekintett a szakma az intézmény indulására: „Ez az intézmény biztosithatja a szükséges ellenörzést és egyensúlyt, segit leküzdeni a demokratikus intézményeink csak rövid távon gondolkodni képes beidegzödését, és áthelyezi a fenntartható fejlödés napirendjét a kormányzás és a politikacsinálás középpontjába. "814 Egyes szerzők álláspontja szerint az ombudsmani forma politikailag a legmegfelelőbb a jövő generációk érdekeinek képviseletére, mivel könnyebben elfogadják müködését a hatalom birtokosai, ${ }^{815}$ és sikeres is lehet érdekképviseleti tevékenysége.

Emellett más szervezetek is foglalkoznak a fenntartható fejlődés kérdéseivel. A Nemzeti Fenntartható Fejlődési Tanácsot a Magyar Köztársaság hosszú távú fenntartható fejlődésével kapcsolatos tervezési és egyeztetési folyamat feladatairól szóló 100/2007. (XI. 14.) országgyülési határozat hozta létre ,, a hazai fenntartható fejlődési alapelvek, célkitüzések, átfogó feladatok meghatározásának elösegitése, a vonatkozó tervezési és egyeztetési feladatok koordinálásának támogatása, a nyilvánosság és a társadalmi részvétel erösitése érdekében”. ${ }^{816}$ A Nemzeti Fenntartható Fejlődési Tanács müködését a Nemzeti Fenntartható Fejlödési Tanács közjogi jogállásáról, jogköréről, összetételéről és feladatairól, valamint müködési kereteiről szóló 57/2008. (V. 22.) Országgyülési határozat szabályozza.

Összegzésként: véleményem szerint szükség van arra, hogy a mindenkori alkotmányozó hatalom olyan szabályokat foglaljon az alaptörvénybe, melyek tekintettel vannak a jövő generációk életére, a fenntartható fejlődésre, a környezetvédelemre, az államadósságra. Talán túlzó ennek az elvnek az alkalmazása, és már önálló hatalmi ágként tekintünk a jövő generációra, amikor a jelenkori döntéshozók sem a társadalmi, a gazdasági, sem a politikai körülményeit nem ismerik az eljövendőnek. Így veszélyes lehet komoly befolyást biztosítani egy teljes mértékben bizonytalan személyi körnek. Vajon az egykori európai döntéshozók sejtették, hogy jelenleg milyen komoly problémát okoz majd az üvegházhatású gázok kibocsátása a modernizáció áraként, és

keresztül vezet az út.” M. LÁSZLÓ FERENC: Törvénytervezet a jövő nemzedékek ombudsmanjáról: Gyámhatóság. $2007 / 15$.

http://magyarnarancs.hu/belpol/torvenytervezet_a_jovo_nemzedekek_ombudsmanjarol_gyamhatosag66964

${ }^{814}$ A magyar zöld ombudsman volt világszerte a példakép, Lukács András interjúja Catherine Pearce-el https://www.levego.hu/kapcsolodo-anyagok/a-magyar-zold-ombudsman-volt-vilagszerte-a-peldakep ${ }^{815}$ BECKMAN -UGGLA 2016, 124-126. pp.

816 a Magyar Köztársaság hosszú távú fenntartható fejlődésével kapcsolatos tervezési és egyeztetési folyamat feladatairól szóló 100/2007. (XI. 14.) országgyülési határozat 5. pont 
csak a jövő nemzedékek képviselőinek csekély beleszólási lehetősége miatt nem történtek meg a válság elkerüléséhez szükséges lépések? Nem tartom mindezt valószínünek, ahogyan azt sem, hogy egy ilyen, a jövő generációk érdekeit képviselő szervezet kialakításával valóban olyan nagy elönyökre tehetünk szert, melyek kompenzálják a hátrányokat. Ahogyan azt sem vélem megfelelő módszernek, hogy egyáltalán ne vegyük figyelembe a jövő generációk érdekeit, hiszen a rövid távú haszon érdekében való cselekvés nem felel meg az alkotmányok általános feladatainak, mivel több generációs dokumentumok általában. Ha komolyan fontolóra vesszük a jövő generációk önálló hatalmi ágként való képviseletét, ezzel az erővel akár az ún. „pillangó-hatást” is beépíthetjük az alkotmányozás folyamatába, hogy a jelenlegi cselekedetek jövőbeli következményeit is figyelembe vegyék.

Mint minden általános megállapításnál, az intergenerációs igazságosságnál is tekintettel kell lenni arra, hogy nincs minden helyzetre alkalmazható tökéletes megoldás. „Mégis, a politikai intézmények a(z intergenerációs igazságosság) szerint való alakitása - bármilyen keveset is lehet tudni következményeikröl a konkrét történeti kontextusban - sokkal jobban szolgálhatja a társadalmi igazságosságot, mintha csak elfogadnánk azokat a politikai intézményeket, melyek éppen rendelkezésre állnak, vagy ha megpróbálnánk a lehetö leginkább „demokratikussá”, „hatékonnyá” vagy „,legitimmé” tenni.,"817

817 VAN PARJIS 1998, 327. p. 


\section{Alkotmányellenes alkotmánymódosítások alkotmányossági vizsgálata}

Az alkotmányellenes alkotmánymódosítások témája népszerüvé vált az utóbbi időben a magyar $^{818}$ és a nemzetközi ${ }^{819}$ szakirodalomban egyaránt. Az alkotmány stabilitásának szempontjából azért szükséges ennek a kérdésnek a vizsgálata, mivel az alkotmány stabilitását erősítő garanciák közül ez képes az alkotmány szövegének érintetlenül hagyásával hatást előidézni, hiszen egy alkotmánymódosítás alkotmányellenességének megállapítása mindig komoly vitát vált ki az adott közegben. Miközben látszólag a szöveg szintjén túli az értelmezés, valójában az a kérdés, hogy lehetővé teszi-e pusztán a szöveg az alkotmányellenes alkotmánymódosítások megsemmisítését, vagy azt éppen a szöveg félretételével éri el a vizsgálatra jogosult szerv. Hol van az a pont, amelyet túl lehet lépni, ahol a szövegtől eltérö értelmet kell tulajdonítani a rendelkezéseknek annak érdekében, hogy elkerülhető legyen a demokrácia, a jogállamiság sérelme? Egyáltalán van ilyen pont? Túl lehet lépni a puszta szövegen a „nagy egész” védelmének érdekében? A formális joguralom vagy a természetjogi igazságosság az előbbre való?

Nem célom minden kérdésre választ találni, álláspontom szerint nincs is objektív válasz erre a kérdésre, mivel gyakran szubjektív szempontok alapján ítélik meg, hogy mit tekintenek előbbrevalónak. Az alkotmányellenes alkotmánymódosítás kérdésének

${ }^{818}$ DRINÓCZI 2015, 361-378. pp.; DRINÓCZI TíMEA: Gondolatok az Alkotmánybiróság 61/2011 (VII. 12.) AB határozatával kapcsolatban. Jura 2012/1. 37-46. pp.; FRÖHLICH JOHANNA: Az alkotmány zártsága és ellentmondás-mentessége - az alkotmánymódositások felülvizsgálatának lehetöségei és határai. in: GÁRDOS-OROSZ FRUZSINA - SZENTE ZOLTÁN (szerk.): Alkotmányozás és alkotmányjogi változások Európában és Magyarországon. Nemzeti Közszolgálati Egyetem Közigazgatás-tudományi Kar Budapest, 2014. 195-208. pp.; GÁRDOS-OROSZ 2014, 167-184. pp.; KOCSIS 2011, 3-17. pp.; LEGÉNY KRISZTIÁN: Alkotmányellenes alkotmánymódositások? Magyar Jog 2006/3. 129-139. pp.; SÓLYOM PÉTER: Alkotmánymódositás mint alkotmánysértés? A Verfassungsdurchbrechung problémája a német alkotmányos hagyományban. in: GÁRDOS-OROSZ FRUZSINA - SZENTE ZOLTÁN (szerk.): Alkotmányozás és alkotmányjogi változások Európában és Magyarországon, Nemzeti Közszolgálati Egyetem Közigazgatástudományi Kar Budapest, 2014. 144-166. pp.; SZENTE 2013, 11-21. pp.; SZENTE 2014, 209-241. pp.; VINCZE ATTILA: Az Alkotmánybíróság határozata az Alaptörvény negyedik módositásáról Az alkotmánymódositás alkotmánybirósági kontrollja. Jogesetek Magyarázata 2013/3. 19-35. pp.; ZsugYó 2011, 52-62. pp.

${ }^{819}$ A teljesség igénye nélkül: ALBERT 2009, 5-47. pp.; BARAK 2002, 321-341. pp.; BARANGER, DENIS: The Language of Eternity: Judicial Review of the Amending Power in France (or the Absence thereof). Israel Law Review, Vol 44. 2011. 389-428. pp.; KeLBEY, CHARLES A.: Are There Limits to Constitutional Change? Rawls on Comprehensive Doctrines, Unconstitutional Amendments, and the Basis of Equality. Fordham Law Review, Vol. 72, Issue 5, 2004, 1503-1519. pp.; RozNAI 2013, 657-719. pp.; RozNAI 2017; ROZNAI - YOLCU 2012, 175-207. pp.; ALBERT 2016, 143-206. pp.; SAMAR 2009, 688-748.pp.; DIXON, ROSAlIND - LANDAU, DAVID: Transnational constitutionalism and a limited doctrine of unconstitutional constitutional amendment. International Journal of Constitutional Law (2015), Vol. 13 No. 3. 606-638. pp. 
felmerülése azonban olyan helyzetre enged utalni, amikor szükség lehet a kérdés alaposabb vizsgálatára az alkotmány stabilitásának szempontjából is. Ugyanis az alkotmány szövegének módosítása, vagy annak elmaradása ahhoz is vezethet, hogy informális úton változik meg az alkotmány szövegének elfogadott értelme, vagy új alkotmányt fogadnak el a probléma megoldásának érdekében adott esetben. Az eredmény mindenképpen kihatással bír az alkotmány stabilitására, akár megerősítve, akár gyengítve azt.

\subsection{Fogalmi keret}

Azokban az országokban, ahol megingani látszik a hatalmi ágak megosztásának demokratikus elve, hamar elökerül az alkotmány értelmezésére hatáskörrel rendelkező szerv -gyakran kisebbségi állásponttal rendelkező tagjai- azon álláspontja, hogy korlátozza a törvényhozó hatalom túlkapásait. Annak érdekében, hogy helyreálljon az egyensúly a hatalmi ágak között, kiterjeszti saját hatáskörét az értelmezésre jogosult szerv, bár ez azzal a veszéllyel is jár, hogy ezzel túlhatalomra tesz szert.

Már sokan vizsgálták ezt a kérdést, például az USA jogtudósai között gyakran felmerülő téma volt a múlt század első évtizedeiben. ${ }^{820}$ A bonni alkotmány elfogadása után kidolgozott elméletek egyike került át az indiai Legfelső Bíróság gyakorlatába Dietrich Konradnak köszönhetően. ${ }^{821}$ A téma egyre népszerübb, hiszen már szinte minden országnak van kartális alkotmánya, de az alkotmányozási helyzetek nem olyan gyakoriak, egyre többször kerül elötérbe az alkotmány módosítása. De vajon meddig terjeszkedhet az alkotmánymódosító hatalom? Azokban az országokban, ahol szabályozott az alkotmánymódosító hatalom hatásköre, könnyü eldönteni a kérdést. Ott, ahol az alkotmány nem határozza meg pontosan, hogy az alkotmánymódosító hatalom milyen mértékü változást fogadhat el, nagyobb a mozgástér az alkotmányt megváltoztatni kívánók számára. Amennyiben van az alkotmány értelmezéséért felelős szerv, az dönthet úgy, hogy meghúzza a határt az alkotmánymódosítás számára.

Egyesek szerint a népszuverenitás elméletével ellentétes, ha egy, nem a nép által választott tagokból álló szerv felülbírálja a nép által választott szerv döntését, bár ezt a szervet az alkotmány hozta létre. Hiszen az egyértelmü, hogy a többi jogszabály

\footnotetext{
${ }^{820}$ ROZNAI 2017, 39-42. pp.

${ }^{821}$ ROZNAI 2017, 44. p.
} 
esetében rendelkezik a felülbírálat jogával, ha alkotmányellenességet észlel, viszont korlátozott ebben az esetben, mivel az alkotmány szövege köti. Mi a teendő azonban akkor, ha az alkotmány elfogadott módosítása alapjaiban változtatja meg a szöveg jelentését? A módosítás hatására akár a teljes alkotmány szövegének jelentése is megváltozhat. Erre a kérdésre eltérő válaszok születtek, a leghíresebb talán az indiai Legfelső Bíróság a kérdésre kidolgozott elmélete.

A vizsgálatnál el kell különíteni az explicit és implicit örökkévalósági klauzulák eseteit. Explicit örökkévalósági klauzulák esetében konkrétan a szövegbe foglalt örökkévalósági klauzulák találhatóak az alkotmányban, vagyis nemcsak lehet, hanem kell is vizsgálni az alkotmánymódosítások alkotmányellenességét. Implicit örökkévalósági klauzulák esetében a hatáskörrel rendelkező szerv „olvasztja ki”, „találja meg" az örökkévalósági klauzulákat a szövegben. ${ }^{822}$

Az alkotmánybíróságok müködésének legfőbb célja, hogy ellenőrizzék a jogrendszer alkotmányosságát, és fellépjenek az alkotmányellenes jogszabályokkal szemben. Mivel a jogszabályi hierarchia csúcsán az alkotmány áll egy alkotmánnyal rendelkező, alkotmányos rendszerben, ezért nem okoz problémát bármely jogszabály alkotmányellenességének megállapítása. Ha magát az alkotmány szövegét módosító rendelkezés kerül szembe az alkotmány eredeti szövegével, dilemmát okoz annak megítélése, hogy milyen minőségü az alkotmánymódosítás: már alkotmányi rangúnak kell tekinteni, és ezáltal nem vizsgálhatja az alkotmánybíróság. Vagy amíg nem épül be a szövegbe, addig nincs alkotmányi rangban, ezért tartalmi szempontból is vizsgálható a módosítás? Netán egyenrangúnak tekintjük, de megbontaná az alkotmány koherenciáját az új rendelkezés? Ezzel a kérdéssel számos alkotmánybíróság is szembekerült már, eltérő válaszokra jutva.

Azokban az országokban, ahol nem terjedt el a kelsen-i sui generis alkotmánybírósági modell, de nem zárják ki az alkotmány szupremáciáját a többi jogszabállyal szemben, ${ }^{823}$ sőt vizsgálatot is lehetővé tesznek, általában a „rendes” legfőbb bírói fórumra ruházzák a vizsgálathoz szükséges hatáskört. Az USA Legfelső Bírósága által kialakított gyakorlatnak ${ }^{824}$ megfelelően számos ország teszi lehetővé legfőbb bírói fóruma számára az alkotmányos vizsgálatot. Ennek során szembekerülhetnek és szembe is kerültek a már említett alkotmányt módosító normák alkotmányossági gondjával.

\footnotetext{
${ }^{822}$ DRINÓCZI 2016a, 256-261. pp.

${ }^{823}$ Nem úgy, mint Nagy-Britannia például.

${ }^{824}$ Marbury v Madison 5 U.S. 137 (1803)
} 
Ezért a továbbiakban a „hatáskörrel rendelkező szerv” kifejezést használom arra a szervre vonatkozóan, amely hatáskörrel bír az alkotmánymódosítások vizsgálatára, függetlenül attól, hogy alkotmánybíróságról vagy a rendes bíróságról van szó.

\subsection{Példák egyes országok gyakorlatából}

\subsubsection{Egy implicit példa - India}

Indiában nincs explicit örökkévalósági klauzula az alkotmányban, vagy bármely más, az alkotmány módosítását szabályozó rendelkezés. A Legfelső Bíróság ennek ellenére megállapította hatáskörét az alkotmánymódosítások alkotmányellenességének vizsgálatára. Ehhez a döntéshez az a folyamat vezetett, amelynek során a kormány igyekezett saját hatalmát alkotmánymódosításokkal megerősíteni. Az évtizedeken át húzódó „csata” eredményeként a Legfelső Bíróság kidolgozta azt a doktrínát, amely explicit örökkévalósági klauzulák nélkül is lehetővé teszi bizonyos alkotmánymódosítások alkotmányellenességének megállapítását. ${ }^{825}$ A döntések közül a leghíresebb a Kesavananda Bharati v. State of Kerala, ${ }^{826}$ amelyben 7-6 arányban, de megállapította a bíróság, hogy a parlament nem változtathatja meg az alkotmány alapvető szerkezetét (basic structure) ${ }^{827}$ A terjedelmes döntés újdonsága az volt, hogy hatáskört állapított meg önmagának a testület az alkotmánymódosítások vizsgálatára annak érdekében, hogy korlátozza a túlterjeszkedő végrehajtó hatalmat. A hatalmi egyensúly fenntartásának védelmére saját hatáskörét bővítette a Legfelső Bíróság, amivel viszont szintén elmozdította a status quo-t, alkotmányos kíméletlenséggel reagálva az alkotmányos kíméletlenségre. ${ }^{828}$ Megváltozott a korábbi erőegyensúly, és egyre inkább elmérgesedett a helyzet, ${ }^{829}$ amely a Legfelső Bíróság győzelmével végződött. Az ,alapvető szerkezet”-elmélet részévé vált az alkotmányos rendszernek, bár annak meghatározása, hogy pontosan mi tartozik az alapvető szerkezethez, a kezdetektől ellentmondásos, már a Kesavananda-döntésben is külön-külön katalógusokat állapítottak meg a bírák. ${ }^{830} \mathrm{Ez}$ a veszélye az értelmezéssel kialakított

825 ROZNAI 2017, 42-47. pp.; JACOBSOHN, GARY JEFFREY: An unconstitutional constitution? A comparative perspective. International Journal of *Constitutional Law Volume 4, Number 3, 2006. 470476. pp.

${ }^{826}$ Kesavananda Bharati ... vs State Of Kerala And Anr on 24 April, 1973

${ }^{827}$ ROZNAI 2017, 44. p.

${ }^{828}$ Alkotmányos kíméletlenség: lásd az 5. fejezetet.

${ }^{829}$ ROZNAI 2017, 45. p.

${ }^{830}$ GÖZLER 2008. 94. p. 
hatalomnak. Miközben a cél nemes, eredménye lehet kevésbé az, ha a testület nem tud megegyezni, vagy horribile dictu olyan célban találják meg a tagok a közös pontot, ami negatívan hat az alkotmányos rendszerre. Ennek következményei akár rosszabbak is lehetnek, mint a végrehajtó hatalom esetleges túlzott térnyerése. Ha a hatáskörrel rendelkező szerv az alkotmányt felhasználva gyakorlatilag bármilyen kérdésben átértelmezheti az alkotmányt, az komoly veszélyekkel járhat. ${ }^{831}$ Figyelembe véve a lehetséges aggályokat, gyakran nincsenek meg a megfelelö eszközei a hatáskörrel rendelkező szervnek ahhoz, hogy fellépjen a túlhatalommal szemben. Ebben az esetben egy aktivista testület szerint a figyelmeztetés nem elég, mást is kell tennie annak érdekében, hogy megakadályozza a jogállamiság szintjének csökkenését, netán megszünését. Azonban egy kiskapu megnyitásának nem látott következményei lehetnek, ezért az atlanti-térségben nem mondható tipikusnak az „alapvető szerkezet”elmélet elterjedése, ${ }^{832}$ amennyiben nincsenek reális, a jogállamiságot fenyegető veszélyek.

Az indiai elméletnek nagy hatása lett számos ország alkotmányos müködésére más kontinenseken és Ázsiában is. A bangladesi Legfelső Bíróság Fellebbviteli Tanácsa 1989-ben vette át az elvet, és azóta is kitart mellette. ${ }^{833}$ Pakisztánban lassú fejlődés után, 2015-ben mondta ki a Legfelső Bíróság, hogy korlátozott a parlament alkotmánymódosító hatalma. ${ }^{834}$ A taiwani Főbírák Tanácsa 2000-ben állapított meg alkotmányellenességet alkotmánymódosítás ügyében. ${ }^{835}$ Thaiföldön 2012-ben rámutatott az Alkotmánybíróság, hogy mivel az alkotmányt népszavazással fogadták el, azt újraírni szintén csak népszavazással lehet. ${ }^{836}$ Más kontinenseken is hódít ez az elv: Kenya, ${ }^{837}$ Kolumbia, ${ }^{838}$ Peru, $^{839}$ Belize $^{840}$ is átvette. A konkrét átvételen és alkalmazáson kívül számos más ország is foglalkozott az elmélettel, akár döntésekben, akár a kapcsolódó szakirodalomban. ${ }^{841}$ Egyes szerzők szerint Latin-Amerikában az

${ }^{831}$ SZENTE 2014, 238-240. pp.

${ }^{832}$ GÖZLER 2008, 66-97. pp.

${ }^{833}$ ROZNAI 2017, 47-49. pp.

${ }^{834}$ ROZNAI 2017, 49-51. pp.

${ }^{835}$ ROZNAI 2017, 54. p.

${ }^{836}$ ROZNAI 2017, 55. p.

${ }^{837}$ ROZNAI 2017, 59. p.

838 Colón-Ríos, JoEl: Beyond Parliamentary Sovereignty and Judicial Supremacy: the Doctrine of Implicit Limits to Constitutional Reform in Latin America. 44(3) Victoria University of Wellington Law Review (2013) 528-531. pp.

${ }^{839}$ ROZNAI 2017, 67. p.

${ }^{840}$ ROZNAI 2017, 68-69. pp.

${ }^{841}$ ROZNAI 2017, 70. p. 
alkotmányellenes alkotmánymódosítást arra alapítva állapítják meg a bíróságok, hogy megsértette „a nép kizárólagos alkotmányozási jogát.”, vagyis a Parlementet korlátozzák a néppel szemben a bírák. ${ }^{842}$

Az indiai Legfelső Bíróság hosszú harc eredményeként sikeresen érvényesítette a bírói szupremácia elvét, ám ennek nemzetközi elismertsége és számos idézése ellenére nem vált általánossá ez az elv, különös tekintettel Európára, bár kétségtelen, hogy jelentősége egyre nő. ${ }^{843}$

\subsubsection{Egy explicit példa-Törökország}

Törökország jelenleg hatályos alkotmányát 1982-ben fogadták el. ${ }^{844} \mathrm{~A}$ török alkotmányban levő örökkévalósági klauzulák indították el azt a folyamatot, melynek eredményeként a török Alkotmánybíróság megsemmisített általa alkotmányellenesnek vélt alkotmánymódosítást.

A török alkotmányban található örökkévalósági klauzulák közt szerepel a köztársasági államforma, a demokratikus, szekularizált jogállam alapelve, a béke, szolidaritás és igazság, az emberi jogok, valamint Atatürk nacionalizmusa, és a preambulumban megfogalmazott alapelvek (pl. népszuverenitás, hatalmi ágak elválasztása, nacionalizmus) tiszteletben tartása. ${ }^{845}$ Emellett meghatározásra kerül, hogy Törökország egységes állam, a török az államnyelv, valamint a zászló, a himnusz és a főváros is. ${ }^{846} \mathrm{~A}$ török alkotmányban levő örökkévalósági klauzulák explicitek, vagyis konkrétan meg van határozva, hogy ezen rendelkezések nem változtathatóak meg alkotmánymódosítással. ${ }^{847}$

Különös jelentőségre tettek szert ezek a rendelkezések, föleg a köztársasági államforma a török Alkotmánybíróság ítélkezési gyakorlatában. Ugyanis a testület az idők folyamán a köztársasági államformát kiterjesztően értelmezte. Először az Alkotmánybíróság megállapította, hogy van hatásköre az alkotmánymódosítások vizsgálatára. 1970-ben

${ }^{842}$ COLON-RiOS 2013, 524. p.

${ }^{843}$ ROZNAI 2013, 657-719. pp.

${ }^{844}$ A török alkotmány módosításáról népszavazás volt 2017-ben, mely egységes angol nyelvü szövegben még nem érhető, az alábbi linken a módosítások szövege olvasható: http://www.trtworld.com/referendum/18-ways-the-turkish-constitution-might-change-334921

${ }^{845}$ A Török Köztársaság Alkotmánya 2. cikk

${ }^{846}$ A Török Köztársaság Alkotmánya 3. cikk

${ }^{847}$ A Török Köztársaság Alkotmánya 4. cikk ,, The provision of Article 1 of the Constitution establishing the form of the state as a Republic, the provisions in Article 2 on the characteristics of the Republic, and the provisions of Article 3 can not be amended, nor can their amendment be proposed." 
megsemmisített egy alkotmánymódosítást, amelyet alkotmányellenesnek talált. ${ }^{848}$ Egy 1971-es alkotmánymódosítás megállapította az Alkotmánybíróság hatáskörét a formai vizsgálatra (formal regularity). ${ }^{849}$ A testület 1980-ig ötször semmisített meg alkotmánymódosítást erre támaszkodva, ${ }^{850}$ mivel tágan értelmezték a rendelkezéseket (pl. a bírói függetlenség elve része a jogállamiságnak, ami integráns része a köztársasági államformának, tehát a bírói függetlenséget sértő alkotmánymódosítás alkotmányellenes. $^{851}$ A többi döntés is hasonló logika mentén épült fel: az Alkotmánybíróság a köztársasági államformába beleértette annak jellemzőit is, a formal regularity fogalmára építve. Az Alkotmánybíróság döntései véglegesek, erga omnes hatályúak, ezért megfelelően tudtak érvényesülni, kikerültek az alkotmányból a megsemmisített szakaszok.

Az 1982-es alkotmány szükítette a testület mozgásterét, és a formal regularity helyett konkretizálta, hogy mit vizsgálhatnak. ${ }^{852}$ 2008-ban ismét a köztársasági államforma jellemzőire hivatkozott a testület, mégpedig a szekularizációval kapcsolatban, a „Fejkendő-döntés” néven elhíresült ügyben, amelyben az egyetemek fejkendő viselési tilalma volt a központi kérdés. ${ }^{853}$ 2010-ben egy alkotmánymódosításhoz kapcsolódóan semmisített meg a testület módosító rendelkezéseket. ${ }^{854}$

2016 óta megváltozott az alkotmányos helyzet, ugyanis az áprilisi népszavazáson vitatott módon, ${ }^{855}$ de többségbe kerültek a prezidenciális rendszert támogatók szavazatai. ${ }^{856} 2010$ óta, mikor jelentős változások történtek a bírákra vonatkozó szabályokban, ${ }^{857}$ megváltozott a bíróság hozzáállása is, a végrehajtó hatalmat jobban támogató álláspontot vett fel, bár népszerüsége nem csökken az egyéni panaszok

${ }^{848}$ GÖZLER 2008, 40-41. pp.

${ }^{849}$ GÖZLER 2008, 42 p.

${ }^{850}$ GÖZLER 2008, 42-47. pp.

851 GÖZLER 2008, 43. p.

852 GÖZLER 2008, 47-48. pp.

853 ROZNAI - YOLCU 2012, 175. p.

854 ZSUGYÓ VIRÁG: Az alkotmánymódositások birói felülvizsgálata Török-magyar párhuzamok. Fundamentum 2014/1-2. 31. p.

855 Turkey referendum: Key reactions http://www.bbc.com/news/world-europe-39615403

${ }^{856}$ The 2017 Turkish Constitutional Referendum Deniz Gungen Tolga Bag - Apr 19, 2017

http://www.apcoworldwide.com/blog/detail/apcoforum/2017/04/19/the-2017-turkish-constitutionalreferendum;

SHAHEEN, KAREEM: Erdoğan clinches victory in Turkish constitutional referendum https://www.theguardian.com/world/2017/apr/16/erdogan-claims-victory-in-turkish-constitutionalreferendum

https://www.theguardian.com/world/2017/apr/16/erdogan-claims-victory-in-turkish-constitutionalreferendum

857 ÖZBundun, Ergun: Turkey's Constitutional Reform and the 2010 Constitutional Referendum, Mediterranean Politics, Panorama, 2011. 193-194. pp. 
benyújtási lehetőségének bevezetése miatt. ${ }^{858}$ Találhatóak a megváltoztathatatlan alapelvek között olyan rendelkezések, melyek alapot nyújthatnának az alkotmányellenes alkotmánymódosítás megállapítására (demokratikus jogállam, hatalmi ágak elválasztása), azonban eddig ilyen nem történt, és nem is valószínű, hogy megtörténne a jelenlegi helyzet szerint. Ha ez a tendencia nem változik, akkor megállapítható lesz a török alkotmánybíráskodás aktív időszakának lezárulta.

\subsubsection{Egy, „elszalasztott lehetőség”859 - Magyarország}

Az alkotmányellenes alkotmánymódosításnak már az elnevezése is kérdéseket ébreszt, hiszen hogy lehet valami alkotmányellenes, ha az alkotmány részévé válik? Formai szempontokat figyelembe véve egyszerübb megválaszolni ezt a kérdést, hiszen ha nem a megfelelő eljárási szabályok szerint fogadnak el egy alkotmánymódosítást, akkor Magyarországon az Alkotmánybíróság megállapítja annak alkotmányellenességét és megsemmisíti, ahogy azt az Alaptörvény S) cikkének (3) bekezdése meghatározza. Ezt az Alkotmánybíróság is elfogadja, azonban ennek alkotmányba foglalása előtt is voltak ilyen jellegü ügyek a testület előtt. ${ }^{860}$

Az alkotmánymódosítások tartalmi szempontú vizsgálata ezzel szemben mélyebb és szenvedélyesebb vitát váltott ki, mivel ennek megítélése kérdéses. A tartalmi vizsgálat ellentmondásossága az Alkotmánybíróság vonatkozó határozataihoz csatolt különvéleményekben és párhuzamos indokolásokban is fellelhető, ám szakirodalmi vita is kialakult ebben az ügyben. Először a gyakori alkotmánymódosítások, később pedig az ÁR kapcsán lángolt fel a diskurzus, majd a negyedik Alaptörvény-módosítást követően újra előtérbe került a téma.

\footnotetext{
${ }^{858}$ DER, Bertil EMraH: Populism and the Turkish Constitutional Court: the Game Broker, the Populist and the Popular, VerfBlog, 2017/5/02, http://verfassungsblog.de/populism-and-the-turkish-constitutionalcourt-the-game-broker-the-populist-and-the-popular/, DOI: https://dx.doi.org/10.17176/20170502122830 .

${ }^{859} \mathrm{Az}$ elnevezés ötlete: PóCZA KÁLMÁN: Többségi demokrácia és gyenge alkotmánybiráskodás: egy elszalasztott lehetőség. (szerk.) GÁRdOS-Orosz FruZSINA; SZENTE ZOLTÁN: Jog és politika határán. Alkotmánybíráskodás Magyarországon 2010 után. HVG-ORAC Kiadó, 2015. 185-212. pp.

${ }^{860}$ Például 23/1994. (IV. 29.) AB végzés, ABH 1994, 375, 293/B/1994. AB végzés, ABH 1994, 862, 1260/B/1997. AB határozat, ABH 1998, 816.
} 
Az Alaptörvény elfogadását, kidolgozásának körülményeit több szempontból is vizsgálták hazai szerzők, ${ }^{861}$ az alkotmányellenes alkotmánymódosítások kérdésével már ekkor is foglalkoztak. ${ }^{862}$

Azonban 2010 elött nem váltott ki különösebb visszhangot, amikor az Alkotmánybíróság vizsgálta az alkotmány módosítását, ${ }^{863}$ és a testület állásfoglalása is szinte teljesen egységes ${ }^{864}$ volt ebben a kérdésben, nem volt kiemelkedő jelentősége. 2010 után azonban a széleskörü alkotmányjogi változások révén a szakmai vitákban központi helyre került az alkotmányellenes alkotmánymódosítás kérdése, különösen azután, hogy az Alkotmánybíróság is felülvizsgálta korábbi álláspontját ${ }^{865}$ a kérdésben. Már számos munka vizsgálta ezeket a határozatokat, ${ }^{866}$ nem célom részletes ismertetésük, csak a lényeg kiemelésével törekszem a stabilitás szempontjából releváns gondolatok bemutatására.

Az első ilyen jellegü döntés a 61/2011 (VII. 13.) AB határozat volt, amelyben az alkotmányellenes alkotmánymódosítás kérdése felmerült. A testület a számos indítványozó által támadott különböző alkotmányos és Abtv.-beli ${ }^{867}$ rendelkezések ügyében vizsgálta saját hatáskörét az alkotmánymódosítások megsemmisítésére. A nemzetközi példák és saját korábbi gyakorlatának áttekintése után a testület megállapította: közjogi érvénytelenség megállapítására van hatásköre, valamint, a sorozatos, egyéni képviselői indítvánnyal benyújtott alkotmánymódosítási módszer sérti a jogállamiságot. ${ }^{868}$ Az alkotmány stabilitásával kapcsolatban megfogalmazta a testület, hogy „A sorozatos, országgyülési képviselők által kezdeményezett, sürgősséggel, rövid

${ }^{861}$ Lásd pl. ABLONCZY BÁLINT: Az alkotmány nyomában. Elektromédia 2011; Az elveszejtett alkotmány, MAJTÉNYI LÁSZLÓ - SZABÓ MÁTÉ DÁNIEL (szerk.), L’Harmattan Kiadó, Eötvös Károly Intézet, 2011.

${ }^{862}$ ABLONCZY 2011, 31-32, 48, 75-76, 91-92, 114-115, pp.; MAJTÉNYI-SZABÓ 2011, 96-108. pp.

${ }^{863}$ Kivétel: ERDŐs 2015, 319-321. pp.

${ }^{864}$ Lábady Tamás különvéleménye az 1260/B/1997 AB határozathoz

865 ZSUGYÓ 2014, 24-26. pp.

${ }^{866}$ DRINÓCZI 2012, 37-46. pp.; KoCSIS 2011, 3-17. pp.; SZENTE 2013, 11-21. pp.; VINCZE 2013, 3-12. pp.; ZSUGYÓ 2011, 52-62. pp.

${ }^{867}$ Még a régi Abtv, az 1989. évi XXXII. törvény

868 61/2011 (VII. 13.) AB határozat, ABH, 2011, 317. „Egyrészt a szokatlanul nagy számú alkotmánymódositás (tizenhárom hónap alatt tíz alkalommal, ebböl hét hónap alatt kilencszer, számos tárgykört érintve, ezek közül van, amelyiket többször is), másrészt az a gyakorlat, hogy az Alkotmány módosítására vonatkozó törvényjavaslatokat a kilencböl hét esetben nem a kormány, hanem országgyülési képviselök nyújtották be, tette vitathatóvá az alkotmánymódositásokkal kapcsolatos eljárások elfogadhatóságát, a jogállam követelményének valómegfelelöségét. Az egyéni képviselői inditványra történö törvénymódositás, de különösen az Alkotmány módositása ilyen módon azért vet fel a demokratikus jogállam követelményéhez kapcsolódóan súlyos problémát, mert az országgyülési képviselök esetében szinte teljes mértékben kizárt az, hogy a törvénymódositó javaslatuk benyújtása elött megfelelö alapossággal elözetes számításokat és elemzéseket végezzenek, egyeztessenek és tárgyaljanak az érdekelt felekkel. Igy nagy az esély arra, hogy hatásait és következményeit tekintve kellöképpen át nem gondolt törvénymódositásokat vagy akár alkotmánymódositást fogad el az Országgyülés." 
idő alatt lefolytatott alkotmánymódositások, amelyek a megfelelö egyeztetéseket mellözték, az érdemi plenáris és bizottsági vitát nélkülözték, veszélyeztetik a hatályos Alkotmány stabilitását. " 869

Felhívta a figyelmet arra a testület, hogy formailag megfeleltek a szabályoknak az alkotmánymódosítások. Valamint meghatározta, hogy mi minősülhet mércének az alkotmánymódosításokhoz a jövőben. Emellett megállapította, hogy saját mércéjét nem változtathatja meg az Alkotmánybíróság, de az alkotmányvédelmi szint nem csökkenthetö.

Végül a testület kimondta: „A hatalommegosztás rendszerében az Alkotmánybíróság hatalma is korlátozott hatalom. Ebböl következöen nem vonja hatáskörébe az Alkotmányt és az Alkotmányt módositó új normák felülvizsgálatát az Alkotmányba foglalt, kifejezett felhatalmazás nélkül. "870

Az Alkotmánybíróság tehát nem vette fel a kesztyüt, kimondta, hogy nem fog túllépni saját hatáskörén, de felvázolta, hogy milyen esetekben korlátozott az alkotmánymódosító hatalom.

A 45/2012 (XII. 29.) AB határozatban az Alkotmánybíróság az Alaptörvényhez kapcsolt ÁR alkotmányosságát vizsgálta az alapvető jogok biztosának indítványára, megállapította több rendelkezés alkotmányellenességét, és megsemmisítette azokat.

Végül arra a következtetésre jutott a testület, hogy vizsgálhatja az ÁR alkotmányosságát, ${ }^{871}$ bár felhívta a figyelmet a következőkre:

„Az alkotmányos legalitásnak nemcsak eljárásjogi, formai, közjogi érvényességi, de tartalmi követelményei is vannak. A demokratikus jogállam alkotmányossági kritériumai, egyben nemzetközi egyezményekbe foglalt, a demokratikus jogállami közösségek által elismert és elfogadott alkotmányos értékek, alapelvek és alapvetö demokratikus szabadságjogok, illetve az ezekkel részben egybeeső úgynevezett ius cogens. Adott esetben az Alkotmánybíróság a demokratikus jogállam alkotmányos tartalmi követelményeinek, garanciáinak és értékeinek a töretlen érvényesülését, alkotmányba foglalását is vizsgálhatja. "872

Ennek értelmében van olyan határ, amit nem léphet át az alkotmánymódosító hatalom, mert ebben az esetben az Alkotmánybíróság fel fog lépni a demokratikus jogállam

\footnotetext{
869 61/2011 (VII. 13.) AB határozat, ABH 2011, 318.

${ }^{870} 61 / 2011$ (VII. 13.) AB határozat, ABH 2011, 322.

871 45/2012 (XII. 29.) AB határozat [66]

$87245 / 2012$ (XII. 29.) AB határozat [118]
} 
védelmének érdekében, vagyis célzás történt arra, hogy az Alkotmánybíróság, ha kell, kész aktív értelmezéssel hatáskört megállapítani magának, és megvédeni a jogállamiságot. ${ }^{873}$

Az alkotmány stabilitásával kapcsolatban is fogalmazott meg gondolatot az Alkotmánybíróság:

„Az Alkotmányba rövid időn belül nagyszámú, és nem az Alkotmány szabályozási tárgykörébe tartozó rendelkezés került be, a gyakori módositások megnehezitették az Alkotmány hatályos normaszövegének a követését és megállapitását. Az említett módositásokkal a közjogi hagyományoktól és gyakorlattól gyökeresen eltérő olyan új alkotmánymódositási gyakorlat alakult ki, amely veszélyeztette az Alkotmány stabilitását és időtállóságát, ezen keresztül az alkotmányos jogállam elveit és követelményeit." 874

Ezt követően az Alaptörvény negyedik módosítása beemelte az Alaptörvénybe azt a rendelkezést, amely szerint az Alkotmánybíróság csak formai szempontból vizsgálhat felül alkotmánymódosítást. ${ }^{875}$

Erre reagálva a 12/2013 (V. 24.) AB határozat zárta le ezt a vitát az Alkotmánybíróság oldaláról, ugyanis a korábbi figyelmeztetések következményeként elfogadott negyedik alkotmánymódosítás az Alaptörvénybe emelte az ÁR-t. Ismét az alapvető jogok biztosa fordult az Alkotmánybírósághoz azzal az indítvánnyal, hogy utólagosan semmisítsék meg a negyedik Alaptörvény-módosítás általa alkotmányellenesnek tartott pontjait. A testület megállapította, hogy

„(...) az Alkotmánybíróság nem alkothatja, és nem is változtathatja meg az alkotmányt, amelyet védeni hivatott, és amelyet mérceként kell alkalmaznia a jogszabályok

\footnotetext{
873 45/2012 (XII. 29.) AB határozat [119] „,Az alkotmányok tartalmi és eljárási mércéi és követelményei demokratikus jogállamban állandóak. A tartalmi és eljárási alkotmányos követelmények nem lehetnek alacsonyabbak az Alaptörvény idöszakában, mint az Alkotmány(törvény) idöszakában voltak. Az alkotmányos jogállam követelményei továbbra is és folyamatosan érvényesülö követelmények a jelenben és programok a jövöre nézve. Az alkotmányos jogállam konstans értékek, elvek és garanciák rendszere. Az alkotmányos jogállamban egyszer már elfogadott értékek, elvek, garanciák, követelmények szintjei nem csökkenhetnek, és azok érvényesülésének a megkövetelése sem veszithet szigorából. "

874 45/2012 (XII. 29.) AB határozat [49]

875 Magyarország Alaptörvénye S) cikk (3) bekezdés „Az elfogadott Alaptörvényt vagy az Alaptörvény elfogadott módositását az Országgyülés elnöke öt napon belül aláirja, és megküldi a köztársasági elnöknek. A köztársasági elnök a megküldött Alaptörvényt vagy az Alaptörvény megküldött módositását a kézhezvételétöl számitott öt napon belül aláirja, és elrendeli a hivatalos lapban való kihirdetését. Ha a köztársasági elnök úgy itéli meg, hogy az Alaptörvénynek vagy az Alaptörvény módositásának a megalkotására vonatkozó, az Alaptörvényben foglalt eljárási követelményeket nem tartották meg, ennek vizsgálatát kéri az Alkotmánybíróságtól. Ha az Alkotmánybíróság a vizsgálata során nem állapítja meg e követelmények megsértését, a köztársasági elnök az Alaptörvényt vagy az Alaptörvény módositását haladéktalanul aláirja, és elrendeli annak a hivatalos lapban való kihirdetését."
} 
alkotmányossági felülvizsgálata során. Az Alkotmánybiróság müködése során mindvégig következetesen elhatárolódott az alkotmány, annak módositásai és egyes rendelkezései vizsgálatától. A hatalommegosztás rendszerében az Alkotmánybiróság hatalma is korlátozott hatalom. Ebböl következöen nem vonja hatáskörébe az alkotmányt és az azt módositó új normák felülvizsgálatát kifejezett felhatalmazás nélkül. "876

Az alkotmánymódosítás vizsgálatának elutasításával a testület felhívta a figyelmet arra, hogy vannak határok, amelyeket nem lehet túllépni. ${ }^{877}$

A magyar jogirodalomban megfogalmazott álláspontok nem egységesek az alkotmányellenes alkotmánymódosítások megítélésében, vannak szerzők, akik támogatják ezt az elképzelést, ${ }^{878}$ mások ellenzik. ${ }^{879}$

Bár az Alkotmánybíróság végül úgy döntött, hogy tartalmilag tiszteletben tartja az alkotmánymódosítás által beépített változásokat, előtte a helyzet nem volt egyértelmü. Emellett felvázolt korlátokat még az alkotmányozó hatalom számára is. ${ }^{880}$

Az alkotmányellenes alkotmánymódosítás megállapítása már a negyedik alkotmánymódosítás előtt sem lett volna ellentmondásoktól mentes. Nyitott volt az út abba az irányba, amely az értelmezésen keresztül „látná bele” a szövegbe a hatáskört. ${ }^{881}$

876 12/2013 (V. 24.) AB határozat [37]

877 12/2013 (V. 24.) AB határozat [46] „Az Alkotmánybíróság hangsúlyozza, hogy ezekben és más, a jövőben megalkotandó jogszabályokban sem hagyhatók figyelmen kivül az alapvetö jogok egymással összefüggö rendszeréböl, az Alaptörvény E) és Q) cikkeiböl adódó, a mindenkori törvényhozó és alkotmányozó hatalomra is kiterjedö korlátok, melyek az Európai Uniós tagállami kötelezettségekböl, Magyarország nemzetközi jogi kötelezettségeinek teljesitése érdekében a nemzetközi jog és a magyar jog összhangjának biztositásából, illetve a nemzetközi jog általánosan elismert szabályainak elfogadásából következnek. ,

${ }^{878}$ Van erre hatásköre az alkotmánybíróságnak a következő szerzők szerint, lásd: BRAGYOVA - GÁRDOSOROSZ 2016, 51. p.; DRINÓCZI 2016a, 287-288. pp.; ZSUGYÓ 2014, 32.p.

879 Nem ért egyet a koncepcióval a következő szerzö: SZENTE 2014, 13-14. pp.

Az alkotmánymódosítás nem lehet alkotmányellenes, de lehet, hogy nem „épül be” az alkotmányba a Csink-Fröhlich szerzőpáros szerint: CSINK - FRÖHLICH 2012a, 59-62. pp.

880 12/2013 (V. 24.) AB határozat [48] „Anélkül tehát, hogy jelen ügyben a szóban forgó alkotmányi rendelkezések egymáshoz való konkrét viszonyáról állást foglalna, szükségesnek tartja az Alkotmánybíróság hangsúlyozni, hogy - mint az Alaptörvény védelmének legföbb szerve [Alaptörvény 24. cikk (1) bekezdés] - hatáskörei (pl. elözetes és utólagos normakontroll eljárás, alkotmányjogi panaszok vizsgálata, Alaptörvény értelmezése) gyakorlása során az Alaptörvényt - célkitüzésének megfelelöen továbbra is koherens rendszerként értelmezi és alkalmazza, és az Alaptörvény valamennyi, az adott ügy elbirálása szempontjából releváns rendelkezésétfigyelembe veszi és összeméri. Az adott alkotmányossági kérdés elbirálása során - az irányadó szabályok szerint eljárva - tekintetbe veszi továbbá Magyarország nemzetközi szerzödéseiben vállalt, az uniós tagsággal együtt járó kötelezettségeit, valamint a nemzetközi jog általánosan elismert szabályait, az azokban megjelenö alapvetö elveket és értékeket. Mindezen szabályok ugyanis - különös tekintettel az Alaptörvénybe is beépitett értékeikre - olyan egységes rendszert (értékrendet) képeznek, melyek sem az alkotmányozás, sem a jogalkotás, sem pedig az Alkotmánybíróság általi alkotmányossági vizsgálat lefolytatásakor nem hagyhatók figyelmen kivül."

${ }^{881}$ ZSUGYÓ 2014, 23. p. 
Ehhez képest jóval nagyobb vitát váltott ki az alkotmányellenes alkotmánymódosítások kérdésének megítélése, föleg miután nem is olyan távoli lehetőséggé vált ez a 45/2012 (XII. 29.) AB határozat hatására. Ha az Alkotmánybíróság megsemmisítette volna a negyedik alkotmánymódosítást az alkotmány egységességére, valamint a többi, korábban az alkotmány védelmére meghatározott elvre hivatkozva, ${ }^{882}$ annak messzire nyúló következményei lettek volna. Amellett, hogy alkotmányt sértenek, ha nem fogadjuk el az alkotmányozás és az alkotmánymódosítás között különbséget tevő elméleteket egyikét sem, ${ }^{883}$ a lépéssel saját hatáskörüket terjesztik ki önkényesen, túllépve a jogállami határon. Kérdéses, hogy lehet-e, megéri-e egy támadásra hasonló módon reagálni, vagy meg kell tartani saját területünkön a szabályokat annak ellenére, hogy a másik fél már nem a szabálykönyv szerint játszik? Ahogy azt a méltán híres 11/1992 (II. 5.) AB határozat kimondta: „Jogállamot nem lehet jogállam ellenében megvalósítani. "884

Saját pozícióját ásta volna alá a testület, ha belemegy egy méltatlan oda-vissza játékba, melynek sorozatos alkotmánymódosítás, akár a testület megszüntetése is lehetett volna a vége. Mégis lehetett volna határozottabb fellépése az azóta eltelt időben a jogállamiság védelme érdekében, olyan esetekben, amikor megvolt a hatásköre arra nézve, hogy döntést hozhasson az adott kérdésben. 885

Természetesen figyelembe veendő, hogy az Alkotmánybíróság müködését alapjaiban változtatta meg az Alaptörvény és az új Abtv. hatályba lépése, ${ }^{886}$ hiszen a testületnek az eddigi absztrakt normakontroll-központú döntéshozatalról át kellett állnia az egyéni panaszt a központba helyező működésre. ${ }^{887}$

Ha az Alkotmánybíróság átkelt volna a Rubiconon, ${ }^{888}$ azzal eltért volna a kialakult európai irányvonaltól, és csatlakozott volna az indiai Legfelső Bíróság által kialakított

\footnotetext{
882 45/2012 (XII. 29.) AB határozat

883 ROZNAI 2017.

884 11/1992. (III. 5.) AB harározat 1992, 77, 82.

885 Pl. 3191/2017 (VII. 21.) AB harározat

886 Például NASZLADI GEORGINA - TILK PÉTER: Az Alkotmánybiróságra vonatkozó szabályozás átalakulása 2010 után. in GÁRDOS-OROSZ FRUZSINA - SZENTE ZOLTÁN(szerk.): Alkotmánybíráskodás Magyarországon 2010 után, HVGOrac Lap- és Könyvkiadó Kft., 2015. 41-74. pp.; CHRONOWSKI NÓRA: Az Alkotmánybíráskodás sarkalatos átalakitása. MTA Law Working Papers 2014/8. 1-14. pp.

887 Például: SULYOK TAMÁS - SZAKÁLY ZsUZSA: Az alkotmányjogi panasz jogorvoslati jellegének bövülése. in BALOGH ELEMÉR (szerk.): Számadás az Alaptörvényröl Tanulmányok a Szegedi Tudományegyetem Állam- és Jogtudományi Kar oktatóinak tollából. Magyar Közlöny Lap- és Könyvkiadó Kft., 2016. 359-370. pp., VISSY BEATRIX: Az individuális alapjogvédelem kilátásai az alkotmánybiráskodásban Merre mutat az alkotmányjogi panasz iránytüje? Magyar Közigazgatás 2012/2. 28-36. pp.

${ }^{888}$ ERDÖS 2015, 317-348. pp.
} 
doktrínát követő országok gyakorlatához, amely igencsak kontroverziális, különös tekintettel arra, hogy nem volt egységes a testületen belül a kérdés megítélése. Ahogy a Kesavananda-döntés is egy szavazatkülönbséggel nyert, a 45/2012 AB határozat eldöntésekor is kicsi volt a szavazatkülönbség a bírák döntésekor. Az egyik lehetséges forgatókönyv az is lehetett volna, ahogy az Indiában történt, hogy az addigi gyakorlatnak ellentmondva a megsemmisítés ellen szavazó bírák legidősebb tagja lett a Legfelső Bíróság elnöke. Az alkotmányos kíméletlenségre ugyanolyan módon való reagálás egyre csak nehezítheti a helyzet konszenzusos megoldását.

Ezzel szemben a magyar Alkotmánybíróság, mint a francia Alkotmánytanács, elfogadta a korábban alkotmányellenesnek ítélt norma alkotmányba emelését, ${ }^{889}$ elismerve az alkotmány sérthetetlenségét ebből a szempontból, kimondva, hogy az alkotmányt vizsgáló szerv nem áll a nép felett. ${ }^{890}$

Ha elfogadjuk Yaniv Roznai elméletét az alkotmánymódosító hatalom sui generis voltára vonatkozóan, ${ }^{891}$ akkor más szemszögből lehet tekinteni az alkotmányellenes alkotmánymódosítások kérdésére is. Ha az Alkotmánybíróság nem az alkotmányozó hatalom által megalkotott dokumentumot véleményezi, hanem az alkotmánymódosító hatalom által megalkotottat, amely limitáltabb ahhoz képest, ezért nem sérti magát az alkotmányt.

Amennyiben a magyar Alkotmánybíróság tagjainak többsége elfogadta volna ezt a gondolatot, akkor az indiai Legfelső Bíróság által „kitaposott” útra lép, hiszen abban az esetben is egy külföldi szerző elméletére alapozta a testület az alkotmányellenes alkotmánymódosítás megállapítását, amely évekig tartó csatározáshoz vezetett a végrehajtó hatalom és az alkotmánybíráskodási hatalom között. Ha a magyar Alkotmánybíróság megtette volna ezt a lépést, az alkotmányos rend kerülhetett volna veszélybe, az alkotmányos kíméletlenség fokozódott volna, amely beláthatatlan alkotmányos következményekre vezetett volna, azonban a testület mérsékelt hozzáállása nem oldott meg minden felmerült problémát.

\footnotetext{
${ }^{889}$ Két esetben is történt ilyen, lásd: TRÓCSÁNYI 2014, 92.p.

${ }^{890}$ Lásd: POLZIN 2016, 433-436. pp.

${ }^{891}$ ROZNAI 2017, 111. p.
} 


\section{Következtetések és hasznosítási javaslatok}

„, Olyan törvények ezek, amelyeket nem ércbe, és márványba, hanem a polgárok szívébe vésnek; ezek a törvények tekinthetök az alkotmány magvának, (...)”

(Jean-Jacques Rousseau)

A kutatás célja szerint kerültek vizsgálatra az alkotmány stabilitását védő garanciák. A hipotézisben meghatározott szempontok alapján bizonyos garanciák esetében erős stabilitást elősegítő lehetőségek fedezhetőek fel, másoknál kevésbé erősek, azonban mindegyik támogatja az alkotmány stabilitását valamilyen szinten. Célom az volt a vizsgálattal, hogy az egyes garanciákban rejlö különböző lehetőségek vizsgálata után azt elemezzem, milyen módon érvényesülnek ezek jelenleg a magyar alkotmányos rendszerben, és milyen formában lehetne felhasználni, esetleg mostani használatukon változtatni annak érdekében, hogy a magyar alkotmány stabilabbá válhasson.

$\mathrm{Az}$ alkotmány stabilitásának vizsgálata során elengedhetetlen, hogy figyelemmel legyünk a társadalmi, politikai, gazdasági, történelmi környezetre. Egy alkotmány, melyen az adott ország jogrendje alapszik, stabilabb kell, hogy legyen, mint egy egyszerü, „közönséges” törvény. Ha túl gyakran változik, bizonytalanná válik a tartalma, pedig origóként kellene irányt mutatnia az egész jogrendszer számára. Amennyiben nem övezi tisztelet és elfogadás az alkotmány szövegét, az megnehezíti annak gyakorlati érvényesülését. Lehet, hogyha hosszabb idő telik el, a korábban nem egyértelmüen támogatott dokumentum megszerezheti a tiszteletet, de erre nincs garancia. Egyes országokban ezt a történelmi tapasztalat bizonyítja, míg másokban nem. A sikeres átmenetre jó példa a francia V. Köztársaság de gaulle-i alkotmánya, a sikertelenre pedig egyetlen eklatáns példát nem is lehetne kiemelni, hiszen számos vita folyik jelenleg is egyes alkotmányok időtállóságáról értéktartalmáról. Egy biztos: az alkotmányozónak törekednie kell arra, hogy lehetőleg minél nagyobb társadalmi támogatottságot szerezzen annak érdekében, hogy az alkotmány társadalmi elfogadottsága erösödjön.

Az érem másik oldala, ha túl nehéz az alkotmány megváltoztatása/új alkotmány elfogadása. Ebben az esetben könnyen előfordulhat, hogy „elmegy a világ” az alkotmány mellett, nem lesz viszonyítási pont, mivel a benne foglalt szabályok meghaladottá váltak, már nem mutatnak irányt a jogalkotók és a jogalkalmazók 
számára, hanem desuetudo alakul ki a mindennapi müködés biztosításának érdekében. Ha az alkotmány szövege már nem képes betölteni funkcióját, azon változtatni kell annak érdekében, hogy ne csak díszítő elemként szolgáljon, hanem rendelkezzen valódi funkcióval, hiszen egy alkotmány akkor válik az emberek számára jelképpé, ha rendelkezései valóban megjelennek mindennapi életük során, nemcsak elvont, távoli fogalomként ismerik.

Ha egy alkotmány nem tud megfelelően funkcionálni, előtérbe kerülnek az informális alkotmánymódosítási eszközök, melyek támogatják az alkotmányos rendszer müködését, ám ezek sem kínálnak megoldást minden helyzetre.

\subsection{Az egyes garanciák}

Az általam vizsgált garanciák mind elősegíthetik, hogy minél stabilabb legyen egy alkotmányos rendszer, vizsgálatukkal megállapítható, mennyire stabil az adott alkotmány.

A különböző alkotmány stabilitására vonatkozó elméletek elemzése után rátértem az egyes garanciák - s azokon keresztül az egész alkotmányos rendszer stabilitásának tanulmányozására, melyek közül az alábbiakat vizsgáltam, melyek tehát az alkotmány stabilitásának garanciái:

- eljárási eszközök

- örökkévalósági klauzulák

- preambulumok múltra és jövőre utaló rendelkezései

- a történeti alkotmány vívmányai

- a jövő generációk jogai

- alkotmányellenes alkotmánymódosítások.

A vizsgált példák, módok lehetőséget adnak arra, hogy az összehasonlító alkotmányjog szemüvegén keresztül vizsgálva a kérdést de lege ferenda a magyar alkotmányos rendszer számára a stabilitást erősítő javaslatokat tegyünk.

A magyar Alkotmányt 2010-2012 között számos alkalommal változtatták meg, amely változtatási ráta káros hatással bírt a stabilitásra, hiszen egy alkotmánynak ritkábban megváltoztatottnak kell lennie, mint egy rendes törvénynek, mivel az egész alkotmányos rendszer alapja.

A magyar Alaptörvényt hat év alatt hatszor módosították, amely már jobb a korábbi arányokhoz képest, azonban még mindig túl magas ahhoz, hogy stabilitási szempontból 
kedvezőnek ítéljük, különösen, ha a negyedik Alaptörvény-módosítást vizsgáljuk, amely nem csak kisebb módosításokat tett a szövegen, hanem jelentős változásokat eszközölt, ráadásul több ponton ellentmondva az Alkotmánybíróság ítélkezési gyakorlatának. $^{892}$

Egyetértek a Csink-Fröhlich szerzőpárossal abban, hogy nem lehet csak kvantitatív alapon megítélni a kérdést, azonban jelzésértékü a gyakori módosítás. ${ }^{893}$ Lehetnek olyan körülmények, melyek gyakoribb módosítást követelnek meg, de inkább a korábbi módosítások átgondolatlanságát jelzik a túl gyakori változtatások.

Az Alaptörvény az első négy éve alatt majdnem 60 új bekezdéssel gyarapodott, és 30 szakasza változott meg. ${ }^{894}$ A gyakori és nem minden esetben kismértékű változások arra engednek következtetni, ahogy Szente is fogalmaz: „Valójában tehát nem a változó társadalmi igényekhez való folyamatos igazítás jellemzi az Alaptörvényt, hanem az aktuálpolitikai érdekek kiszolgálása, legitimálása, s igy sokkal inkább szimbolizálja az alkotmányos rendszer változékonyságát, mint stabilitását" $" 895$

A magyar Alaptörvény stabilitása tehát nem ítélhető jónak, hiszen ha megnézzük az egyes alkotmány stabilitását szolgáló garanciák érvényesülését a gyakorlatban, a következőket állapíthatjuk meg:

\subsubsection{Eljárási eszközök}

Magyarországon az alkotmány módosítását szabályozó eljárási eszközök közül kettő van az alkotmányszövegbe foglalva, mint kötelező elem: a kezdeményezési jog korlátozása és a minősített többség megkövetelése. A kezdeményezési jog szükítése nem tekinthető különösen erős garanciának, a köztársasági elnök, a kormány, valamint országgyülési képviselő vagy országgyülési bizottság kezében van, ${ }^{896}$ vagyis nem túl zárt ez a kör, hiszen az országgyűlési képviselök elérése széles kör számára lehetőség.

A minősített többség, jelen esetben kétharmad ${ }^{897}$ előírása már erősebb garancia lehet abban az esetben, ha a szükséges többség eléréséhez szükség van egyeztetésre a pártok között. Ahogy láthattuk a magyar rendszerben 2010 előtt, ha nincs meg a szükséges

\footnotetext{
${ }^{892}$ SZENTE 2016, 218-220. pp.

${ }^{893}$ CSINK - FRÖHLICH 2016, 29. p.

${ }^{894}$ SZENTE 2016, 238. p.

895 SZENTE 2016, 239. p.

${ }^{896}$ Magyarország Alaptörvénye (2011. április 25.) S) cikk (1) bekezdés

${ }^{897}$ Magyarország Alaptörvénye (2011. április 25.) S) cikk (2) bekezdés Összes országgyülési képviselő kétharmada, ún. nagykétharmad.
} 
kompromisszum a kétharmados többség eléréséhez, önmagában ez a rendelkezés elég ahhoz, hogy kifejezetten merevvé tegye az alkotmányos rendelkezéseket, és az alkotmány merevvé váljon. Ha a kormánypártnak megvan a szükséges többsége ahhoz, hogy megváltoztassa az alkotmányt, és nem törekszik szélesebb körü konszenzusra, hanem megelégszik a módosításhoz szükséges ezen többség önálló legitimáló erejével, akkor „nem lesz ereje” a minősített többségnek, nem áll korlátként az alkotmány megváltoztatására képes többség előtt, sorozatos alkotmánymódosítást eredményezhet, ahogy az Magyarországon láthattuk mind az Alaptörvény elfogadása előtt, mind utána. Ennek az eljárási eszköznek az erőssége az aktuális parlamenti helyzettől függ, ami nem jó garancia, hiszen a stabilitást nem jól szolgálja az az eszköz, amely a választási eredményektől függően lehet nagyon gyenge, de nagyon erős is.

\subsection{2 Örökkévalósági klauzulák}

A magyar alkotmányban nincsenek örökkévalósági klauzulák, bár egyes szerzők azt felfedezni vélik, meghatározott módszerek segítségével „olvasztják ki” azokat az Alaptörvény szövegéböl. ${ }^{898}$

Természetesen vannak az Alaptörvénynek olyan rendelkezései, melyek mindenképpen kiemeltnek tekinthetőek, hiszen megváltoztatásuk az egész alkotmányos rendszer változását maga után vonná (népszuverenitás, hatalommegosztás, jogállamiság, alapjogok védelme), ${ }^{899}$ ám nem részesülnek kiemelt védelemben a többi rendelkezéshez képest a szöveg szintjén. A vonatkozó alkotmánybírósági gyakorlat már persze más kérdés.

A valódi örökkévalósági klauzulákat tartalmazó alkotmányokkal rendelkező országok alkotmányos rendszerében sem gyakori, hogy valódi jelentőséggel bírnának ezek a rendelkezések (pl. Németország) ${ }^{900}$ Bizonyos országokban pedig akkor is jelentős az örökkévalósági klauzulák szerepe, ha konkrétan nem tartalmaz olyat a szöveg (pl. India). ${ }^{901}$

Magyarországon sem az alkotmányozó, sem az Alkotmánybíróság nem élt a lehetőséggel, hogy akár explicit, akár implicit örökkévalósági klauzulákat alkalmazzon, olvasszon ki a szövegből. Ez a stabilitási garancia nem tekinthető reális lehetőségnek a

\footnotetext{
${ }^{898}$ DRINÓCZI 2016a, 256-261. pp.; BRAGYOVA - GÁRDOS-OROSZ 2016, 50-56. pp.

${ }^{899}$ Magyarország Alaptörvénye (2011. április 25.) B), C) cikk

${ }^{900}$ KÜPPER 2014, 185-194. pp.; SZENTE 2014, 209-241. pp.

${ }^{901}$ ROZNAI 2017, 209. p.
} 
jelenlegi magyar rendszerben a stabilitás erősítését szolgáló rendelkezések számba vételekor.

\subsubsection{A preambulumok múltra és jövöre utaló rendelkezései}

A magyar preambulum, vagyis a Nemzeti Hitvallás tartalmaz bőven a múltra és a jövőre vonatkozó rendelkezéseket. Az Alkotmánybíróság használja is indokolásaiban a preambulum bizonyos elemeit, azonban soha nem magában, hanem más alkotmányos elvekkel együtt. A preambulum szerepéből következően más elbírálás alá esik normativitási szempontból, mint az alkotmány többi része. Álláspontom szerint jól kezeli a magyar Alkotmánybíróság ezt a garanciát, amikor az ingoványos talajon igyekszik mégis biztos lábbal járni, hiszen a preambulum rendelkezéseinek túlzó használata, felhívása sem egészséges egy alkotmányos rendszer számára, veszélyekkel járhat. $^{902}$

A vizsgált rendelkezések és használatuk erösítették az alkotmány stabilitását, úgy vélem, jó gyakorlat alakult ki az Alkotmánybíróságon, mert merik használni a preambulumot, de nem esnek túlzásba ezzel, mert ezen rendelkezések önálló alkalmazása már ingataggá tenné az érvelési rendszert.

\subsubsection{A történeti alkotmány vívmányai}

A történeti alkotmány vívmánya speciális magyar garancia, melyet az Alaptörvény hozott létre. ${ }^{903}$ A jogszabályi felhatalmazás az Alkotmánybíróság hatáskörébe utalta a vívmányok megállapítását, a testület pedig elkezdte ezt a munkát, gyakorlatában megjelent több vívmány is, melyekkel elösegítették az alkotmányos rendszer szilárdítását. Az első vívmány, a bírói függetlenség kiolvasztása után nem esett túlzásba a testület, nem jött létre hosszú lista, ${ }^{904}$ bár ennek az is oka lehet, hogy nincs egységes álláspont a testületen belül ebben a kérdésben, nem alakult ki egységes szempontrendszer. Többek között az Alaptörvény R) cikkében foglal értelmező rendelkezés alapján is, az Alkotmánybíróság esetről esetre határozza meg, hogy mi minősül a történeti alkotmány vívmányának. Ebben a folyamatban jelentett új lépést a 22/2016 (XII. 5.) AB határozat, mivel adott egy listát a történeti alkotmány

\footnotetext{
902 VÖRÖS 2016a 53-55. pp.

903 SZAKÁLY 2015, 28-34. pp.

904 33/2012. (VII. 17.) $\mathrm{AB}$ határozat, 6/2013. (III. 1.) $\mathrm{AB}$ határozat, 28/2014. (IX. 29.) AB határozat, 34/2014. (XI. 14.) AB határozat, 17/2015 (VI. 5.) AB határozat, 22/2016 (XII. 5.) AB határozat
} 
vívmányairól, ${ }^{905}$ és összefüggésbe hozta a kérdést az alkotmányos önazonossággal is. A történeti alkotmány vívmányai álláspontom szerint alkalmasak arra, hogy erősítsék az alkotmány stabilitását, quasi örökkévalósági klauzulaként szolgálva segítik elő azt. Ez az unikális magyar garancia jó példaként szolgálhat arra, hogy lehetséges összekötni a chartális alkotmány előtti történeti alkotmány legjelentősebb eredményeit a kartális normaszöveggel annak érdekében, hogy erősítsék annak stabilitását. ${ }^{906} \mathrm{Nem}$ hiba nélküli ez a módszer, hiszen esetlegessége veszélyes lehet, valamint egy túl aktív alkotmánybíróság túlzásokba is eshet alkalmazásával, hiszen ez a garancia egy slippery slope - azaz csúszós lejtő - lehetőségét foglalja magában. Ha nincsenek megfelelő korlátok, ami behatárolja a döntési lehetőséget, mint ebben az esetben, mivel a hatáskörnek nincs az Alaptörvényben szabályozva, akkor új „gumiklauzula” kialakulása fenyeget.

\subsubsection{A jövő generációk jogai}

A preambulum jövőre utaló lehetséges rendelkezései mellett az alkotmányokban egyre gyakrabban megjelennek a jövő nemzedékek jogai.

A magyar alkotmányt vizsgálva a következők állapíthatóak meg: a Nemzeti Hitvallás tartalmaz a jövő generációk érdekeivel foglalkozó rendelkezéseket, emellett az L) cikk, áttételesen az N) cikk, a Q) cikk és a 38. cikk is érinti a jövő nemzedékek érdekeinek kérdését.

Megjelennek tehát a jövő generációk érdekei, de nem tételesen a jogok, azt kevés alkotmány biztosítja konkrétan a jövő nemzedékek számára. ${ }^{907} \mathrm{Az}$ alkotmánybírósági gyakorlat sem emeli ki a jövő generációkat, még nem született olyan határozat, mely egyedüli, központi kérdéssé emelte volna a vizsgálat során jogaikat. ${ }^{908}$

Ha figyelembe vesszük a jövő generációk érdekeit, azzal erősíthető az alkotmány stabilitása, hiszen nekik az az érdekük, hogy minél jobb minőségü alkotmányos rendszert kapjanak, és ennek része a stabilitás. A magyar rendszer jelenleg nem tesz komoly lépéseket ennek támogatására, hiszen az alapvető jogok biztosának jövő

\footnotetext{
905 „, a szabadságjogok, a hatalommegosztás, a köztársasági államforma, a közjogi autonómiák tisztelete, a vallásszabadság, a törvényes hatalomgyakorlás, a parlamentarizmus, a jogegyenlöség, a bírói hatalom elismerése, a velünk élö nemzetiségek védelme" 22/2016 (XII, 5.) AB határozat [65]

906 Szmodis Jenő ezt nevezi többrégeü alkotmányosságnak, lásd: SzMODIS 2013, 1. p.

${ }^{907}$ Bolívia, Egyiptom, Japán, Malawi, Marokkó, Mozambik

908 Azok a határozatok, melyek foglalkoztak a jövő nemzedékek érdekeivel, a 10. fejezetben kerültek bemutatásra.
} 
nemzedékek jogaiért felelős helyettese a környezetvédelmi kérdéseket tüzte zászlajára, általában a jövő generációk érdekeit nem kezeli kiemelt prioritásként. Tehát ez a garancia nem tudja elősegíteni az alkotmány stabilitásának erősödését, mivel nincs elég széles körben alkalmazva ahhoz, hogy valós hatással legyen az alkotmány meghatározására.

Érdekes „,kísérlet” lenne, ha megjelenne ez a lehetőség akár az Alaptörvényben, akár az alkotmánybírósági gyakorlatban, vagy ha a jövő nemzedékek biztoshelyettese erősebben foglalkozna ezzel a területtel. Vajon volna befolyása a döntéshozók választásaira? Vajon olyan döntések születnének, melyek a jövőben valóban elősegítik a jövő generációk helyzetét?

\subsubsection{Alkotmányellenes alkotmánymódositások alkotmányossági vizsgálata}

Az alkotmányellenes alkotmánymódosítások kérdése többször is felmerült a közelmúltban az alkotmányos diskurzusban, különösen a negyedik alaptörvénymódosítás után. Az Alkotmánybíróság 45/2012 (XII. 29.) határozatában tett is néhány célzást az alkalmazására, azonban valódi alkotmányellenes alkotmánymódosítás megállapítására nem került sor, a testület elfogadta az Alaptörvénybe foglalt korlátokat hatáskörére vonatkozóan. Az alkotmányellenes alkotmánymódosítás alkalmazása nem minden esetben üdvözítő megoldás, úgy vélem, az Alkotmánybíróság helyesen tette, hogy nem használta ezt a lehetőséget, hiszen alkotmányellenességre alkotmányellenességgel válaszolni nem megoldás, saját reputációjának ártott volna a testület, ha belép a „ringbe”, és elkezdi megsemmisíteni az alkotmánymódosításokat, hiszen az alkotmányos kíméletlenségre ugyanolyan módon válaszolva fokozódhat a helyzet, és elfajulhatott volna az egész folyamat.

Ugyanakkor szükséges megjegyezni, hogy az Alkotmánybíróságnak a testület által alkotmányellenesnek ítélt kérdések alaptörvénybe foglalása ellen fel kell lépnie, csak más módszerrel.

Az alkotmányellenes alkotmánymódosítások garanciája egy veszélyes garancia, mivel az alkotmány stabilitásának erősítése helyett könnyen az alkotmány stabilitását rombolhatja le, amennyiben a politikai élet szereplöi túllépnek korábbi hatásköreiken, és egymást túllicitálva próbálják rendezni a helyzetet. 


\subsubsection{Eredmények}

A magyar alkotmány stabilitása a vizsgált garanciák érvényesülése szempontjából közepesnek mondható. Ha csak az Alaptörvényt vizsgáljuk, és azt tekintjük kiindulási pontnak, megállapítható, hogy hat év alatt hat alkotmánymódosítás túl sok ahhoz, hogy stabil alkotmányról beszélhessünk.

Az első három módosítás nem volt jelentős, azokat kisebb kiigazításoknak tekinthetjük, melyek magukban nem meghatározóak, de ha ehhez hozzávesszük az ÁR szerteágazó tartalmát, megállapítható, hogy folyamatos változásoknak volt kitéve az alkotmány szövegszintje. A negyedik módosítás ezen egyébként megsemmisített ÁR nagy részét emelte be az alkotmány szövegébe, ami jelentős változást hozott. Az ötödik módosítás konszolidációt eredményezett ugyan, de az alkotmány szövege nem jelentéktelen kérdésekben változott meg számottevően. ${ }^{909}$ A hatodik módosítás csak a különleges jogrend szabályait érintette. A tervezett hetedik Alaptörvény-módosítás többek között a szuverenitásra, az EU-val való kapcsolatra vonatkozott volna, vagyis szintén jelentős változásokat eredményezett volna. ${ }^{910}$

Ha megnézzük az alkotmány stabilitásának garanciáit ebböl a szempontból, a következők állapíthatóak meg:

Az eljárási eszközök nem megfelelö eszközök ahhoz, hogy biztosítsák az alkotmány stabilitását.

Örökkévalósági klauzula nincs a magyar rendszerben, de valódi szerep esetén erősíthetné az alkotmány stabilitását.

A preambulumok múltra és jövőre utaló rendelkezései részei a rendszernek, de nem bírnak olyan súllyal, hogy jelentős hatásuk legyen.

A történeti alkotmány vívmányai többször segítették az alkotmányos értékek védelmét, alapozhatóak rájuk stabilitást védő rendelkezések, hiszen az Alkotmánybíróság ide sorolta például a hatalommegosztást és a törvényes hatalomgyakorlást, valamint arra is felhívta a figyelmet, hogy ez nem egy zárt felsorolás. ${ }^{911}$

A jövő generációk jogai megjelennek, de nem olyan súllyal, hogy valódi szerepük legyen az alkotmány stabilitásának biztosításában.

\footnotetext{
${ }^{909}$ SZENTE 2016, 221-222. pp.

910 CHRONOWSKI - VINCZE 2017, 121-122. pp.

911 22/2016 (XII. 5.) AB határozat [65]
} 
$\mathrm{Az}$ alkotmányellenes alkotmánymódosítások vonatkozásában: nincs ilyen garancia a magyar alkotmányos rendszerben, amit a magam részéről nem is tartok aggályosnak, mivel veszélyes alkotmányos garancia.

Az alkotmány stabilitását védő, általam azonosított és elemzett garanciák tehát ily módon jelennek meg a magyar alkotmányos rendszerben. Érezhető, hogy az Alaptörvény stabilitásának erősítése szükséges, ám nem szabad túl merevnek sem lennie az alkotmánynak, azonban lényeges, hogy ne lehessen túl könnyedén megváltoztatni az alkotmányt.

\subsection{De lege ferenda-javaslat}

A következő részben az egyes alkotmány stabilitását erősítő garanciák közül azokat a megoldásokat emelem ki de lege ferenda javaslatként a magyar alkotmányozó számára, melyek az összehasonlító elemzések alapján megfelelőnek bizonyulhatnak az alkotmány stabilitásának ideálisabb kialakításához, külön tekintettel arra, hogy tökéletes megoldás nincs, illetve, hogy az egyes, adott esetben alkalmazott alkotmányjogi transzplantok jellemzőit is megfelelő helyi értéken kell figyelembe venni minden esetben. Az Alaptörvény stabilitásának megfelelősége kényes egyensúlyi kérdés, ahogy minden alkotmány esetében, hiszen minden helyzet egyedi, külön mérlegelést igényel, javaslatom tehát ezen szempontok fókuszban tartásával teszem.

Elsőként kiemelendő, hogy akkor megfelelő egy stabil alkotmány, ha alkotmányos is, érvényesülnek a jogállamiság kritériumai, ám szükséges figyelembe venni, hogy ez mindig a konkrét helyzet vizsgálatával állapítható csak meg.

\section{- Eljárási eszközök}

Az eljárási eszközök vonatkozásában mindenképpen szükség van a stabilitás erősítésére. Javaslom, hogy a lehetséges eljárási eszközök között kerüljön bevezetésre a késleltetés, mégpedig többszöri vita formájában, amelyek között legalább három hónapnak kell eltelnie. Ez a közbeékelődő időintervallum alkalmas lenne arra, hogy jobban megfontolják a módosítást, valamint a közvéleménynek is volna lehetősége alapos tájékozódásra a kérdésben.

Ez lenne a legalkalmasabb eljárási eszköz az alkotmány merevebbé tételéhez úgy, hogy közben el lehessen kerülni a túlzott merevséget, mivel a népszavazással történő megerősítés vagy a két egymást követő parlament általi elfogadás túlzottan elnehezítené az eljárást. A második kamara bevezetését nem tartom indokoltnak pusztán az 
alkotmányozási/alkotmánymódosítási eljárás lassítása okán, bár az Alaptörvény elfogadására és módosítására irányuló jogalkotási eljárás lassítása általánosan nem biztos, hogy hátrányos lenne, akár - egy specifikusan erre a célra létrehozott, és csak ezekben az esetekben aktivált, quasi alkotmányozó nemzetgyűlésként szolgáló második kamara közbeékelésével.

- Örökkévalósági klauzulák és a történeti alkotmány vívmányai

Jelenleg nincsenek a magyar alkotmányban örökkévalósági klauzulák, azonban alkalmazásuk megfontolandó lenne abból a szempontból, hogy azokban az országokban, ahol vannak az alkotmányban ilyen rendelkezések, azok tartalma az alkotmányos identitás elemeivel forr össze bizonyos esetekben. Az alkotmányos identitás elemeinek védelme egyre inkább előtérbe kerül az EU tagállami alkotmánybíróságainak gyakorlatában, ${ }^{912}$ és az örökkévalósági klauzulák így új szerepet és értelmet nyerhetnek, hiszen miközben az alkotmányozás pillanatában komoly jelentőségük volt, az alkotmányozást követő értelmezési gyakorlat általában nem tulajdonít nagy szerepet nekik. ${ }^{913} \mathrm{Az}$ alkotmányos identitás elemeiként jelentőségük megnőne, és alkalmazhatóvá válhatnának a magyar alkotmányos önazonosság egyes elemeinek védelmére is.

Ehhez az alkalmazáshoz szükséges néhány előkérdés vizsgálata: Az örökkévalósági klauzula hat az identitásra, vagy az identitás hatására kerül rögzítésre az örökkévalósági klauzula? Értelmezhető egyáltalán a kérdés ilyen kontextusban? Milyen viszonyban áll egymással az örökkévalósági klauzula és az alkotmányos identitás? Valószínüleg azok a behatások, amelyek az alkotmányozót örökkévalósági klauzula beiktatására késztették, alapjaiban határozták meg az alkotmányos rendszer identitását is, melynek látható manifesztációja lehet az alkotmány szövegi szintjén az örökkévalósági klauzula.

A magyar kontextus vizsgálatához elengedhetetlen a történeti alkotmány vívmányainak beemelése is a vizsgálatba, hiszen azok quasi örökkévalósági klauzulákként szolgálnak, ahogy azt az Alkotmánybíróság is megállapította. ${ }^{914}$ Szükség van-e még emellett külön örökkévalósági klauzulaként való megjelenítésükre? Jelen helyzetben nem tartom szükségesnek, hiszen a történeti alkotmány vívmányai kifejezik ezt a szerepet, azonban

\footnotetext{
${ }^{912}$ SULYOK 2014, 51-60. pp.

913 A föszabályt erősítő kivétel Törökország, ahol az explicit örökkévalósági klauzulákra többször támaszkodott a török Alkotmánybíróság alkotmányellenes alkotmánymódosítás megállapításakor. Lásd: GÖZLER 2008, 42-47. pp.

914 22/2016 (XII. 5.) AB határozat [65]
} 
ha új alkotmányozásra kerül egyszer majd a sor, megfontolandónak tartom az Alkotmánybíróság által addig kimunkált történeti alkotmány vívmányai közül a legfontosabbak örökkévalósági klauzulaként való megjelenítését, mivel így kiemelt védelmük immár az alkotmány szövegének szintjén is megjelenhetne.

$\mathrm{Az}$ alkotmányos önazonosság elemeinek meghatározásával, valamint a történeti alkotmány vívmányainak kimunkálásával stabilabbá válhat maga az alkotmány is, mivel egy alaposan kidolgozott, tudományos érvekkel alátámasztott rendszer lehet csak stabil alapja a szövegnek. ${ }^{915}$ A két gondolat összefüzése egy egyedi, új utat mutathat a magyar alkotmányos gondolkodásnak, mikor kölcsönhatásban fejlődnek, de egy irányba: az alkotmány stabilitásának fejlődése felé.

- A preambulumok múltra és jövőre utaló rendelkezései

A Nemzeti Hitvallás bizonyos rendelkezéseinek beemelése a magyar alkotmánybírósági értelmezési gyakorlatba már megkezdődött, azonban ezek csak kiegészítő szerepben jelenhetnek meg, áttételesen tudják erősíteni az alkotmány stabilitását, ám jelentőségük nem elhanyagolható.

- A jövő generációk jogai

A jövő generációk jogainak alapjai megjelentek már az Alaptörvényben, ami álláspontom szerint jó irány, mivel ennek lehet szerepe az alkotmány stabilitásának erősítésében, viszont itt is figyelni kell arra, hogy könnyen túlzásba lehet esni, hiszen nem tudjuk, hogy pontosan mire lesz szüksége a következö generációknak, milyen érdekeik és érdeksérelmeik jönnek létre. Az azonban biztos, hogy például az élhető környezetre szükségük lesz, ezért a fenntartható fejlődés erőteljesebb megjelenése támogatandó, mely egyúttal elősegíti az alkotmány stabilitásának, az alkotmány szövegének fenntartható fejlődését, illetve annak erösödését is, de anélkül, hogy túl merevvé tenné.

- Alkotmányellenes alkotmánymódosítások alkotmányossági vizsgálata

915 Mindkét kérdés vonatkozásában fontos ezt kiemelni, hiszen még egyik fogalom vonatkozásában sincs megfelelő fogalmi keret, elég csak a történeti alkotmány vívmányainak kzuisztikus jellegére vagy a nemzeti-alkotmányi-alkotmányos-nemzeti alkotmányos identitás fogalmak közötti különbség kérdéseire utalni. 
Az alkotmányellenes alkotmánymódosítás kérdése nem is olyan régen előkerült a magyar Alkotmánybíróság gyakorlatában, az ÁR egyes rendelkezéseinek megsemmisítését kimondó $\mathrm{AB}$ határozatban. ${ }^{916}$ Bár az alkotmányozó kizárta ezt a lehetőséget a formai alkotmánymódosítás-vizsgálat kizárólagosságának alkotmányba emelésével, ${ }^{917}$ amit az Alkotmánybíróság el is fogadott, egy darabig Damoklész kardjaként lebegett a lehetőség a magyar alkotmányos rendszer feje felett.

Az osztrák Alkotmánybíróság azon jogköre megfontolandó a magyar jogrendszerbe való beemelésre, mely lehetővé teszi, hogy a testület minden esetben előzetesen vizsgálja az alkotmánymódosításokat. ${ }^{918} \mathrm{Ez}$ az előzetes alkotmányossági szürő segítene abban, hogy csak az alkotmányos állam elveinek megfelelő alkotmánymódosítások kerüljenek elfogadásra, valamint egymásnak ellentmondó alkotmányos rendelkezések sem kerülhetnének a szövegbe.

Az Alkotmánybíróság ezzel az eszközzel védelmezni tudná az Alkotmány szövegének koherenciáját és véletlenül sem merülhetne fel az alkotmányellenes alkotmánymódosítás gondolata.

Az alkotmány stabilitásának garanciáit a fentiek szerint tudom elképzelni a magyar alkotmányos rendszerben annak érdekében, hogy stabilabbá váljon az Alaptörvény, mivel „A jogrendszer élén álló alkotmány alapvető funkciója az alkotmányos szabályok stabilizálása”. 919

Úgy vélem, szükség van a változtatásra annak érdekében, hogy erösödjön az Alaptörvény stabilitása. Az egész alkotmányos rendszer állapotának megítélése összetett kérdés, jelen munka csak az alkotmány szövegszintjét befolyásoló garanciákkal foglalkozott, mely csupán egy szelete ennek a területnek. Ennek ellenére megállapítható, hogy jelentőséggel bíró kérdés, mivel bár „,Alkotmányunk élő valami, tehát fejlődik.",920 vagyis folyamatosan változik az értelmezési kerete, miközben azért a szöveget is szükséges lehet változtatni. Mindezt azonban visszafogott tempóban kell megtenni, mivel „A folyamatos alkotmánymódositások nem szolgálják az alkotmány stabilitását. Egy alaptörvénnyel szemben minimálisan elvárható követelmény, hogy

\footnotetext{
916 45/2012 (XII. 29.) AB határozat

917 Magyarország Alaptörvénye (2011. április 25.) S) cikk (3) bekezdés

918 Ausztria Alkotmányának 44. cikke elkülönít alkotmánymódosítást és teljes körü módosítást, erre alapozza az Alkotmánybíróság hatáskörét, lásd GÖZLER 2008, 24., 34-40. pp.

919 RÁCZ 1995, 121.p.

${ }^{920}$ Teleki Pál országgyülési beszédei. II. kötet A „Stádium” kiadása, Budapest. 369.
} 
annak szabályait a politikai erök hosszabb ideig tiszteletben tartsák, és alkotmánymódositásra csak akkor kerülhessen sor, ha a társadalmi fejlödés az alkotmány megváltoztatását valóban igényli. "921

Bár minden alkotmányozó arra törekszik, hogy munkája minél hosszabb távon érvényesülhessen, rövidebb-hosszabb idő után szükségessé válhat a módosítás, hiszen ahogy Varol parafrálja Madison híres gondolatát: ${ }^{922}$ „Ha elörelátó és jóságos angyalok írnák az alkotmányokat, nem lenne szükség átmeneti alkotmányokra.". ${ }^{923}$ Vagyis amíg nem valósul meg a tökéletes alkotmány és a tökéletes alkotmányozás utópiája, addig szükség lesz alkotmánymódosításra, és fontos annak vizsgálata, hogy milyen gyakran és milyen módon nyílik erre lehetősége az arra hatáskörrel rendelkezőnek, mikor mondható stabilnak egy alkotmány.

A vizsgált garanciák szerepének összegzéséül táblázatba foglaltam a szempontokat:

\begin{tabular}{|c|c|c|}
\hline Garancia & Szerep & Javaslat \\
\hline Eljárási eszközök & Nem elegendő & $\begin{array}{c}\text { Késleltetés - többszöri } \\
\text { vita }\end{array}$ \\
\hline $\begin{array}{c}\text { Örökkévalósági } \\
\text { klauzulák }\end{array}$ & Nincs & Quasi örökkévalósági \\
klauzulák
\end{tabular}

1. táblázat. A vizsgált garanciák jellemzése.

921 TRÓCSÁNYI 1996, 175. p.

922 „Ha az emberek angyalok lennének, nem lenne szükség kormányzatra.” James Madison: The Federalist No. 51 The Structure of the Government Must Furnish the Proper Checks and Balances Between the Different Departments Independent Journal Wednesday, February 6, 1788, http://www.constitution.org/fed/federa51.htm ${ }^{923}$ VAROL 2014, 463. p. 


\section{Irodalomjegyzék}

ABLONCZY BÁLINT: Az alkotmány nyomában. Elektromédia 2011, = ABLONCZY 2011

Ackerman, Bruce: We the People 1. Foundations. The Belknap Press of Harvard University Press, Cambridge, Massachusetts, London, England, 1993. = ACKERMAN 1993

ACKerman, Bruce: We the People 2. Transformations. The Belknap Press of Harvard University Press, Cambridge, Massachusetts, London, England, 1998.

ACKerman, Bruce: We the People 3. Civil Rights Revolution. The Belknap Press of Harvard University Press, Cambridge, Massachusetts, London, England, 2014.

ÁDÁM ANTAL: Az alkotmányi értékek fejlödési irányairól. Jura 2002/1. = ÁDÁM 2002

ÁdÁm ANTAL: Az alkotmányozásról. In: FeKETE BALÁzS - HoRVÁthy BALÁzS KREISZ BRIGITTA (szerk.): A világ mi magunk vagyunk... Liber Amicorum Imre Vörös. HvgOrac Lap- és Könyvkiadó Kft., 2014.

ÁDÁM ANTAL: Bölcseletek, vallások, jogi alapértékek. Pécs, 2015.

ÁDÁM PÉTER: Franciaország alkotmányos rendje és politikai intézményei. Corvina, 2007. = ÁDÁM 2007

AlBERT, RichARD: Nonconstitutional Amendments. Canadian Journal of Law and Jurisprudence, Vol. XXII., No. 1. January 2009. = ALBERT 2009

Albert, RICHARD: The Theory and Doctrine of Unconstitutional Constitutional Amendment in Canada. Boston College Law School Faculty Papers 1-1-2016. = AlBert 2016

AntAl AtTILA: A jövő nemzedékek érdekei az Alaptörvényben. In: VEREBÉLYI IMRE (szerk.): Az állam és a jog alapvető értékei a változó világban. A Széchenyi István Egyetem Állam- és Jogtudományi Doktori Iskolájának konferenciakötete, Győr, 2012. 
Antal AtTIla: A preambulum ornamentikája és közjogi ereje. in: AnTAL AtTILA NovÁK ZoltÁn - SzentPÉteri NAgY RichARD (szerk.): Az Alkotmány arca Preambulum-tanulmányok, L’Harmattan, Budapest, 2011.

ANTAL AtTILA: Alkotmányozási korszakok és technikák. Közjogi Szemle 2013/2.

Antal AtTILA: Az Alkotmánybiróság határozata korábbi gyakorlatának érvényességéröl - Megdönthetö vélelem az Alkotmányon alapuló gyakorlat mellett, Jogesetek Magyarázata, 2013/2.

Antal AtTILA: Politikai és jogi alkotmányosság Magyarországon. Politikatudományi Szemle XXII/3. = ANTAL 2013

ARISZTOTELÉSZ: Politika II. könyv Gondolat Kiadó, 1994 = ARISZTOTELÉSZ

AUBERT, JEAN F.: La constitution francaise de 4 octobre 1968 Zeitschrift für Schweizerishes Recht, 1960/1.

Auerbach, Bruce - ReINHARt, Michelle: Antonin Scalia's Constitutional Textualism: The Problem of Justice to Posterity. Intergenerational Justice Review. 1/2012 (12. Jg.) = AUERBACH-REINHART 2012

Az elveszejtett alkotmány, MAJTÉNYI LÁSZlÓ - SZABÓ MÁTÉ DÁNIEL (szerk.), L’Harmattan Kiadó, Eötvös Károly Intézet, 2011. = MAJTÉNYI - SZABÓ 2011

BALOGH ÁDÁM: Fejezetek Görögország újkori történetéböl A szabadságharctól napjainkig. Szeged, 2013. = BALOGH 2013

BALOGH ELEMÉR: 200 éves a norvég alkotmány. Alkotmánybírósági Szemle, 2014/1. = BALOGH 2014

BerKes LiLla - FeKETE BALÁzs: Nemzeti Hitvallás: csupán díszitő szavak? Közjogi Szemle 2017/1. szám = BERKES - FEKETE 2017 
BALOGH ElEMÉR: Az Aranybulla helye a magyar alkotmánytörténetben. In: LAJOS Besenyei - GÉZA Érszegi - PedrazZA Gorlero, Maurizio (szerk.): De Bulla Aurea Andreae II. Regis Hungariae MCCXXII, Edizioni Valdonega, Verona, 1999.

BÁNKUTi Miklós et al. Amicus Brief a Velencei Bizottságnak az Alaptörvény negyedik módositásáról. Fundamentum 2013/3. = BÁNKUTI 2013

BaraK, Aharon: A Judge on Judging: The Role of a Supreme Court in a Democracy. 116 Harvard Law Review 19. (2002) = BARAK 2002

BARAK, AHARON: Unconstitutional Constitutional Amendments. Isreal Law Review, $2011 / 44$.

BARANGer, Denis: The Language of Eternity: Judicial Review of the Amending Power in France (or the Absence thereof). Israel Law Review, Vol 44. 2011.

BATÓ SzILVIA: Büntetőjogi adalékok a jogbiztonság-fogalom kialakulásához Magyarországon. In: GÁL ISTVÁN LÁSZLÓ (szerk.): Tanulmányok Tóth Mihály professzor 60. születésnapja tiszteletére, Pécs, 2011.

BECKERMAN, WILFRED: The impossibility of a theory of intergenerational justice. In Tremmel, Joerg Chet: (szerk.): The Handbook of Intergenerational Justice, Edward Elgar, 2006.

Beckman, Ludvig - UgGla, FredriK: An Ombudsman for Future Generations: Legitimate and Effective? In: GONZÁLEZ-RICOY, IÑIGO - GOSSERIES, AXEL (szerk.): Institutions for Future Generations, Oxford University Press, 2016. = BECKMAN UGGLA 2016

Beckman, Ludvig: Democracy and Future Generations. Should the Unborn Have a Voice? In: Merle, JeAn-Christophe (szerk.), Spheres of Global Justice Volume 1. Global Challenges to Liberal Democracy. Political Participation, Minorities and Migration, Springer, 2013. = BECKMAN 2013 
Behrendt, Christian: The Process of Constitutional Amendment in Belgium. In: Contaides, Xenophon (szerk.), Engineering Constitutional Change, A Comparative Perspective on Europe, Canada and the USA, Routledge, 2013. = BEHRENDT 2013

BEKINK, BERNARD: Balancing constitutional stability and flexibility: An evaluation of the constitutional amendment procedures, Journal of South African Law, Vol. 2004, Issue 4 (2004).

BeSSELINK, LeONARD F. M.: Constitutional Identity Before and After Lisbon, Utrecht Law Review, 2010/(6)3.

BezemeK, Christoph: Constitutional Core(s): Amendments, Entrenchments, Eternities and Beyond Prolegomena to a Theory of Normative Volatility, The Journal Jurisprudence, 2011, Vol. 11.

BIHARI MiHÁLY: Az alkotmányozó hatalomról in: TAKÁCS IMRE (szerk.): Az alkotmányozás jogi kérdései. Az Eötvös Loránd Tudományegyetem és a linzi Johannes Kepler Egyetem 1995. július 6-7-én tartott alkotmányjogi szimpóziuma Bp. ELTEEötvös K. 1995.

Blount, Justin, - Elkins, ZaChary - Ginsburg, Tom: Does the Process of Constitution-making Matter? in: ToM GINSBURG, (szerk.): Comparative Constitutional Design, University of Chicago, School of Law, Cambridge University Press, 2012.

BLUTMAN LÁSZLÓ: A magyar Lisszabon-határozat: befejezetlen szimfónia luxemburgi hangnemben. Alkotmánybírósági Szemle, 2010/2. = BLUTMAN 2010

BlutMan LÁszLó: Szürkületi zóna: az Alaptörvény és az uniós jog viszonya. Közjogi Szemle, 2017/1. = BLUTMAN 2017

BonCZ FERENCZ: Magyar államjog, Athenaeum, 1877. = BonCZ 1877

Borgeaud, Charles: Adoption and Amendment of Constitutions in Europe and America, Translated by Hazen Charles D., Professor of History in Smith College. With 
an introduction by Vincent John M., Associate of the Johns Hopkins University. New York and London: Macmillan and Co. 1895. Pp. xi, 353.

Bozsó GÁBOR: Románia alkotmánya. Alkotmányelemzés. Pro Publico Bono Online Állam- és Közigazgatás-tudományi Szemle 2011/2.

BRAGYOVA ANDRÁS - GÁRDOS-OROSZ FRUZSINA: Vannak-e megváltoztathatatlan normák az Alaptörvényben? Állam- és Jogtudomány, 2016/3. = BRAGYOVA - GÁRDOSOROSZ 2016

Bragyova ANDRÁs: Az új alkotmány egy koncepciója. Közgazdasági és Jogi Könyvkiadó, MTA Állam- és Jogtudományi Intézet, Budapest, 1995.

BRAGYOVA ANDRÁS: Vannak-e megváltoztathatatlan normák az alkotmányban? In: BRAGYOVA ANDRÁS (szerk.): Ünnepi tanulmányok Holló András 60. születésnapjára. Bíbor Kiadó, Miskolc, 2003.

BROWN-WEISS, EDITH: Intergenerational Fairness and Rights of Future Generations Three principles of intergenerational equity form the basis of intergenerational obligations and rights. Generational Justice, 2002/3. = BROWN-WEISS 2002 CHOUdHRY, SuJIT: Ackerman's Higher Lawmaking in Comparative Constitutional Perspective: Constitutional Moments as Constitutional Failures? International Journal of Constitutional Law, Vol. 6, No. 2, (2008).

CHRONOWSKI NÓRA - DrinÓCZI TÍMEA - ZELLER JUdiT: Túl az alkotmányon... Az alkotmányvédelem elméleti és európai kontextusa, továbbá magyar gyakorlata 2010ben, avagy felülvizsgálható-e az alkotmánymódositó törvény az Alkotmánybíróság által. Közjogi Szemle 2010/4. = CHRONOWSKI - DRINÓCZI -ZELLER 2010

CHRONOWSKI NÓRA - VINCZE ATTILA: Önazonosság és európai integráció - az Alkotmánybíróság az identitáskeresés útján. Jogtudományi Közlöny 2017/3. = CHRONOWSKI - VINCZE 2017 
CHrOnOwsKi NóRA: „Integrálódó” alkotmányjog. Dialóg Campus Kiadó, 2005.

CHRONOWSKI NÓRA: Az Alkotmánybíráskodás sarkalatos átalakitása. MTA Law Working Papers 2014/8.

CHRONOWSKI NÓRA: Jogállamiság válságban? Helyzetkép az Európai Unió látószögéből. megjelenés alatt az ELTE ÁJK 350 - Jubileumi tanulmányok, ELTE Eötvös Kiadó, 2018.

Colón-Ríos, Joel: Beyond Parliamentary Sovereignty and Judicial Supremacy: the Doctrine of Implicit Limits to Constitutional Reform in Latin America. 44(3) Victoria University of Wellington Law Review (2013) = COLÓN-Ríos 2013

CSINK LÓRÁNT - FRÖHLICH JOHANNA: A Haining-elv Az alkotmány identitása, stabilitása és változtathatósága. Iustum Aequum Salutare 2016/4. = CSINK - FRÖHLICH 2016

CSINK LÓRÁNT - FRÖHLICH JOHANNA: Egy alkotmány margójára Alkotmányelméleti és értelmezési kérdések az Alaptörvényröl. Gondolat Kiadó, Budapest, 2012. = CsINK FRÖHLICH 2012a

CSINK LÓRÁNT - FRÖHLICH JOHANNA: Történeti alkotmány és kontinuitás az új Alaptörvényben. Közjogi Szemle 2012/1 . = CSINK - FRÖHLICH 2012b

CSINK LÓRÁNT: Az Alkotmánybiróság határozata a birói hivatás felső korhatárának szabályairól - Az elmozdithatatlanság alkotmányjogi fogalma. Jogesetek Magyarázata, 2012/4.

Denning, B. P.: Means to Amend: Theories of Constitutional Change. Tennesse Law Review, Vol. 65. 1997.

De-Shalit, Avner: Why Posterity Matters Environmental policies and future generations. Routlege, 1995. = DE-SHALIT 1995 
Dixon, Rosalind - Ginsburg, TOM: Deciding not to Decide: Deferral in Constitutional Design. Chicago, Public Law and Theory Working Paper No. 389. 2012. $=$ DIXON - GINSBURG 2012

DiXon, RosAlind - LANDAU, DAVID: Transnational constitutionalism and a limited doctrine of unconstitutional constitutional amendment. International Journal of Constitutional Law (2015), Vol. 13 No. 3.

Dixon, Rosalind: Constitutional Amendment Rules: A Comparative Perspective. the University of Chicago Law School, Public Law and Legal Theory Working Paper Series, 347, May 2011.

DrINÓCZI TÍMEA: A 22/2016 (XII. 5.) AB határozat: mit (nem) tartalmaz, és mi következik belöle Az identitásvizsgálat és az ultra vires közös hatáskörgyakorlás összehasonlitó elemzésben. MTA Law Working Papers 2017/1. = DRINÓczI 2017

DRINÓCZI TíMEA: Az alkotmány legitimitásáról. Pázmány Law Working Papers, 2011/3 DRINÓCZI TÍMEA: Az alkotmányos identitásról. Mi lehet az értelme az alkotmányos identitás alkotmányjogi fogalmának? MTA Law Working Papers, 2016/15. = DRINÓCZI $2016 b$

DRINÓCZI TímEA: Gondolatok az Alkotmánybíróság 61/2011 (VII. 12.) AB határozatával kapcsolatban. Jura 2012/1. = DRINÓcZI 2012

DRINÓCZI TÍMEA: Újra az alkotmányozó, az alkotmánymódositó hatalomról és az alkotmányellenes alkotmánymódositásról - az Alaptörvény alapján - Jogtudományi Közlöny 2015. 7-8. = DRINÓCZI 2015

DRINÓCZI TíMEA: Többszintü alkotmányosság müködésben - alkotmányos párbeszéd Magyarországon. Akadémiai nagydoktori thesis, Pécsi Tudományegyetem, 2016. = DRINÓCZI 2016a 
EASTerbrook, Frank H.: Textualism and the Dead Hand. University of Chicago Law

School, Chicago Unbound, 1998. = EASTERBROOK 1998

Ederer, Peer-Schuller, Philipp-Willms, StePhan: The Economic Sustainability Indicator In: TREMMEL ,JOERG CHET (szerk.): The Handbook of Intergenerational Justice, Edward Elgar, 2006.

Edith Brown Weiss-szel, a Georgetown University Law Center professzorával Jávor Benedek beszélget, Fundamentum, 2008/1.

Egyetemes Szöveggyüjtemény, 1793-as francia alkotmány, Emberi és Polgári Jogok Nyilatkozata 28. http://jtd.uw.hu/egyetemesszov.html

Ekeli, Kristian SKagen: How Difficult Should it be to Amend Constitutional Laws? Scandinavian Studies in Law, 2007/52. = EKELI 2007

Elkins, Zachary -Ginsburg, TOM -Melton, JAmes: The Endurance of National Constitutions. Cambridge University Press, 2009. = ELKINS - GinSBURG -MeLTON 2009 ElSTER, Jon: Ulysses Unbound: Studies in Rationality, Precommitment and Constraint., Cambridge University Press, 2000. = ELSTER 2000

ERDŐS CSABA: Rubiconon innen... és túl? Az Alkotmánybíróság gyakorlata az alkotmánymódositások felülvizsgálatának és az alkotmányi szabályok közti kollizió feloldásának területein. in: GÁRDOS-OROSZ FrUZSINA - SZENTE ZOLTÁN (szerk.): Jog és politika határán. Alkotmánybíráskodás Magyarországon 2010 után. HVG-ORAC Kiadó, 2015. = ERDÖS 2015

Fejes ZsuzSAnNa: Constitutional Identity and Historical Constitution Clause in the Hungarian Fundamental Law and its Effects on Constitutional Interpretation. In: Zoltán Szente - FAnni MAndÁK - ZsuZSAnna FeJes (szerk.): Challenges and Pitfalls in the Recent Hungarian Constitutional Development: Discussing the New Fundamental Law of Hungary. Paris: Éditions L'Harmattan, 2015. 
FeKETE BALÁZs: A jéghegy csúcsa. Strukturális értékek az európai alkotmányok preambulumaiban. In: FeKete BALÁzs - HorvÁthy BALÁzs - KreISZ BrigitTA (szerk.): A világ mi magunk vagyunk... Liber Amicorum Imre Vörös. HvgOrac Lap- és Könyvkiadó Kft., 2014. = FEKETE 2014

FEKETE BALÁzS: Preambulumok és nyelvfilozófia avagy a preambulum normativitásáról másképp. Pázmány Law Working Papers 2011/33.

FEKETE BALÁzS: Történeti elemek az EU-tagállamok alkotmány-preambulumaiban. In: LAMM VANDA - MAJTÉNYI BALÁZS - PAP ANDRÁS LÁSZLÓ (szerk.): Preambulum az alkotmányokban. Complex, 2011. = FEKETE 2011

FERDINANDY GÉZA: Magyarország közjoga (Alkotmányjog). Politzer Zsigmond és Fia, Budapest, 1902. = FERDINANDY 1902

FInN, John E.: Constitutions in Crisis: Political Violence and the Rule of Law. Oxford University Press, 1991.

FRÖHLICH JOHANNA: Az alkotmány zártsága és ellentmondás-mentessége - az alkotmánymódositások felülvizsgálatának lehetőségei és határai. in: GÁRDOS-OROSZ FRUZSINA - SZENTE ZOLTÁN (szerk.): Alkotmányozás és alkotmányjogi változások Európában és Magyarországon. Nemzeti Közszolgálati Egyetem Közigazgatástudományi Kar Budapest, 2014.

FrÖHLICH JohanNA: Az örökkévalósági klauzulák dilemmája. in: DrinÓczi TíMEA JAKAB ANDRÁS (szerk.): Alkotmányozás Magyarországon 2010-2011. Pázmány Press, Budapest-Pécs, 2013. = FRÖHLICH 2013

GÁl RÓBERT IVÁN - GULyÁS ATTILA - MEDGYESI MÁRTON: Intergenerációs alkotmány. Társadalomtudományi Kutató Intézet (TÁRKI) Zrt., Mühelytanulmányok, No. 5., Budapest. 2011. http://docplayer.hu/14313497-Intergeneracios-alkotmany.html 
GÁRDOS-Orosz FrUZSINA: Az alkotmánymódositások alkotmányossági felülvizsgálata: elméleti koncepciók, nemzetközi trendek es magyar kérdések. in: GÁRDOS-OROSZ FRUZSINA - SZENTE ZOLTÁN (szerk.): Alkotmányozás és alkotmányjogi változások Európában és Magyarországon. Nemzeti Közszolgálati Egyetem Közigazgatástudományi Kar Budapest, 2014. = GÁRDOS-OROSZ 2014

Gatmaytan, Dante B.: Can Constitutionalism Constrain Constitutional Change? Northwestern Interdisciplinary Law Review, Vol. 3, Issue 1 (Spring 2010).

GÁva KRISZTián: Az Alaptörvény módositásai. Pro Publico Bono, 2014/2.

Gerhardt, Michael J.: Ackermania: The Quest for a Common Law of Higher Lawmaking. William \& Mary Law Review, Volume 40. Issue 5. Article 7.

GOERLICH, HELMUT: Concept of speial protection for certain elements and principles of the constitution against amendments and Article 79 (3), Basic Law of Germany. NUJS Law Review (2008) 1(3)

GöZler, Kemal: Judicial Review of Constitutional Amendments, A Comparative Study. Ekin Press, Bursa, 2008. = GöZLER 2008

GRAY, DAVID: Constitutional Faith and Dynamic Stability: Thoughts on Religion, Constitutions, and Transitions to Democracy. Maryland Law Review 69, no. 26 (2009) = GRAY 2009

GYÖRFI TAMÁS - JAKAB ANDRÁS: 2.\$ [Alkotmányos alapelvek; ellenállási jog] In: JAKAB ANDRÁs (szerk.): Az Alkotmány kommentárja, I., Századvég Kiadó, Budapest, 2009. = GYÖRFI - JAKAB 2009

HABERLe, PETER: A constitutional law for future generations - the 'other' form of the social contract: the generation contract In: TREMMEL, JOERG CHET (szerk.): The Handbook of Intergenerational Justice, Edward Elgar, 2006. 
HAlmai GÁBOR: Alkotmányjog - Emberi jogok - Globalizáció - Az alkotmányos eszmék migrációja. L'Harmattan Kiadó, 2013. = HALMAI 2013

HALMAI GÁBOR: Emberi Jogok. Osiris, 2008.

HAmmons, Christopher. Was James Madison Wrong? Rethinking the American Preference for Short, Framework-Oriented Constitution. American Political Science Review 93(4), 1999.

Holló ANDRÁS: Az alkotmánybíróság viszonya az alkotmányhoz: Az alkotmányozó és a törvényhozó hatalom elhatárolása. In: PETRÉTEI JÓZSEF (szerk.): Emlékkönyv Ádám Antal egyetemi tanár születésének 70. évfordulójára. Pécs: Dialóg Campus, 2000, (Studia iuridica auctoritate Universitatis Pécs publicata)

Holmes, Stephen - Sunstein, CASs R.: The Politics of Constitutional Revision in Eastern Europe. in: SANFORD LEVINSON (szerk.): Responding to Imperfection, The Theory and Practice of Constitutional Amendment. Princeton University Press, Princeton, New Jersey 1995. = HOLMES - SUNSTEIN 1995

HORKAY HÖRCHER FERENC: A Nemzeti hitvallásról. In: JAKAB ANDRÁs - KÖRÖSÉNYI ANDRÁS (szerk.): Alkotmányozás Magyarországon és máshol. Politikatudományi és alkotmányjogi megközelítések. MTA Társadalomtudományi Kutatóközpont Politikatudományi Intézet - Új Mandátum Könyvkiadó, Budapest. 2012. = HORKAY HÖRCHER 2012

Horváth AtTiLA: A magyar történeti alkotmány tradíciói. Alkotmánybírósági Szemle, 2011/1.

HorvÁth Gergely: Az Alaptörvény környezetjogi elöirásai. In: SzOBOSZLAI-KISS KATAlin - Deli Gergely (szerk.): Tanulmányok a 70 éves Bihari Mihály tiszteletére. Győr, Universitas-Győr, 2013. 
JACKSON, VICKI C.: The (myth of un)amendability of the US Constitution and the democratic component of constitutionalism. International Journal of Constitutional Law 2015/3, Vol. 13.

JACOBSOHN, GARY JEFFREY: An unconstitutional constitution? A comparative perspective. International Journal of Constitutional Law Volume 4, Number 3, 2006.

JAKAB ANDRÁS: A jogállamiság mérése indexek segitségével. Iustum Aequum Salutare $2016 / 2$.

JAKAB ANDRÁs: A jogállamiság mérése indexek segitségével. Pázmány Law Working Papers, 2015/12.

JAKAB ANDRÁS: Az alkotmányjog tudománya és oktatása Magyarországon (1990-ig). Jogtörténeti Szemle 2008/2.

JAKAB ANDRÁS: Az európai alkotmányjog nyelve, NKE Szolgáltató Nonprofit Kft., 2016.

JAKAB ANDRÁS: Fenntarthatóság az európai alkotmányjogban, Közjogi Szemle, 2016/3. = JAKAB 2016

JAKAB ANDRÁS: Mire jó egy alkotmány? Kommentár 2010/6.

JÁVOR BENEDEK: Institutional protection of succeeding generations - Ombudsman for Future Generations in Hungary. In: TREMMEL, JoERG CHET (szerk.): The Handbook of Intergenerational Justice, Edward Elgar, 2006.

Kavanagh, AileEn: The Idea of a Living Constitution, Canadian Journal of Law and Jurisprudence, 16(1), 2003. = KAVANAGH 2003

Kelbey, Charles A.: Are There Limits to Constitutional Change? Rawls on Comprehensive Doctrines, Unconstitutional Amendments, and the Basis of Equality. Fordham Law Review, Vol. 72, Issue 5, 2004. 
KILÉNYI GÉZA: Az alaptörvény stabilitását szolgáló garanciák a külföldi alkotmányokban és nálunk. Jogtudományi Közlöny, 1996. (Vol. 51.) No. 3.

KLug, HeInZ: Constitutional Identity and Change. Tulsa Law Review, 2011/47. = KLUG 2011

KoCSIS MikLÓs: Az Alkotmánybiróság határozata az „alkotmányellenes alkotmánymódositások” ügyében Az indokolás koherenciahiányának következményei. Jogesetek Magyarázata 2011/3. = KoCSIS 2011

KovÁcs ÁGnes: Fényevők? A hazai alkotmányelmélet esete a politikai konstitucionalizmussal. Fundamentum 2015/2-3. szám.

KovÁcs István: Az alkotmányfejlödés elvi kérdései. In: KovÁcs István (szerk.): Alkotmány és alkotmányosság, Akadémiai Kiadó, Budapest, 1989.

KUKORELLI ISTVÁN - MÁTHÉ GÁBOR: Közjogi értékeink a preambulumban. In: LAMM VANDA - MAJTÉNYI BALÁZS - PAP ANDRÁS LÁSZLÓ (szerk.): Preambulum az alkotmányokban, Complex, 2011.

KUKORElli IstVÁn: Az alkotmányozás évtizede Közjogi, politikai tanulmányok, parlamenti jegyzetek, Korona Kiadó, Budapest, 1995.

KuKORELli István: Hány éves az Alaptörvény? A régi-új kérdése az Alaptörvényben. Gondolat Kiadó, Budapest, 2017.

KUKORELli ISTVÁN: Húsz éve alkotmányozunk... Közjogi Szemle 2009/3.

KUKORELli IstvÁN: Tradíció és modernizáció a magyar alkotmányjogban, Századvég Kiadó, Budapest, 2006.

Kumar, RAHUl: Wronging Future People: A Contractualist Proposal. In: GosserIES, AXEL - MEYER, LUKAS H. (szerk.): Intergenerational Justice, Oxford University Press, 2009. 
Kumar, VIRENDRA: Basic Structure of the Indian Constitution: Doctrine of Constitutionally Controlled Governance [from Kesavananda Bharati to I.R: Coelho] Journal of the Indian Law Institute Vol. 49, No. 3 (July-September 2007) = KUMAR 2007

KÜPPER, HERBERT: Az alkotmánymódositás és az alkotmánybirósági kontroll megoldás az „örökkévalósági klauzula”? Közjogi Szemle 2013/4.

KÜPPER, HERBERT: Tur Tur, az álóriás? - avagy a Grundgesetz örökkévalósági klauzulájának jelentése a német jogrendszerben. in: GÁRDOS-OrosZ FrUZSINA SZENTE ZOLTÁN (szerk.): Alkotmányozás és alkotmányjogi változások Európában és Magyarországon, Nemzeti Közszolgálati Egyetem Közigazgatás-tudományi Kar Budapest, 2014. = KÜPPER 2014

Lees-Smith, Hastings. B.: The Parliamentary System in Norway. Journal of Comparative Legislation and International Law Third Series, Vol. 5, No. 1, 1923.

LEGÉNY KRISZTIÁN: Alkotmányellenes alkotmánymódositások? Magyar Jog 2006/3. LeIBHOlZ, GeRHARD: The Federal Constituional Court in Germany and the „Southwest Case” The American Political Science Review Volume 4-6, Issue 3 September 1952. = LEIBHOLZ 1952 LEVINSON, SANFORD: Accounting for Constitutional Change (or, how many times has the United States constitution been amended? (A) <26; (B) 26; (C) >26; (D) all of the above) in: LEVINSON, SANFORD (szerk.): Responding to Imperfection The Theory and Practice of Constitutional Amendment, Princeton University Press, 1995. = LEVINSON 1995

LEVInSON, SANFORD: Our Undemocratic Constitution. Oxford University Press, 2006. 
LiJPhart, AREnd: Patterns of Democracy Government Forms and Performance in Thirty-Six Countries, Yale University Press, 1999, Chapter 12: Constitutions Amendment Procedures and Judicial Review, 237 p.;

Loughlin, Martin: The Concept of Constituent Power. Critical Analysis of Law Workshop, University of Toronto, 15 Jan 2013.

Lutz, Donald S.: Toward a Theory of Constitutional Amendment in: SANFORD LEVINSON, (szerk.): Responding to Imperfection, The Theory and Practice of Constitutional Amendment, Princeton University Press, Princeton, New Jersey 1995. = LUTZ 1995a

Lutz, Donald S.: Toward a Theory of Constitutional Amendment, American Political Science Review, Vol. 88., No. 2, June 1994. = LuTZ 1995b

MADISON, JAMES: The Federalist No. 51 The Structure of the Government Must Furnish the Proper Checks and Balances Between the Different Departments Independent Journal Wednesday, February 6, 1788, http://www.constitution.org/fed/federa51.htm Magyar Alkotmánytörténet. (szerk.): MEZEY BARNA Osiris, 2003.

MaJTÉnyi LÁSZló ÉS SzABÓ MÁtÉ DÁNIEL (szerk.): Az elveszejtett alkotmány. L’Harmattan Kiadó, Eötvös Károly Intézet, 2011

McConnell, Michael W: The Forgotten Constitutional Moment.. University of Minnesota Law School. Retrieved from the University of Minnesota Digital Conservancy, https://conservancy.umn.edu/bitstream/handle/11299/167069/11_01_McConnell.pdf?se quence $=1$ \&isAllowed=y $=$ MCCONNELL 1994

MilánKOVICH ANDRÁS - SzEnTGÁli-Tóth BOLdizsÁR: Díszítő elem vagy új értelmezési távlatok? A magyar közjog történeti dimenziói az Alaptörvény tükrében. Közjogi Szemle 2014/1. = MiLÁNKOVICH - SzENTGÁLI-TóTH 2014 
NACSA MóNIKA: Történeti alkotmányunk vívmányai: az új Alaptörvény egyes rendelkezéseinek jogértelmezései próbája. In: VARGA NORBERT (szerk.): Az új Alaptörvény és a jogélet reformja, Szegedi Jogász Doktorandusz Konferenciák II., Szegedi Tudományegyetem Állam- és Jogtudományi Doktori Iskola Kiadványsorozata, Szeged, 2013.

Nagy Attila TiBor: A magyar múlt a preambulumban. in: ANTAL AtTila - NovÁK ZoltÁN - SzEnTPÉteri NAgY RichARD (szerk.): Az Alkotmány arca Preambulumtanulmányok. L’Harmattan, Budapest, 2011.

NAGY ERNÖ: Magyarország közjoga (Államjog). Athenaeum, 1907.

NAGy MikLós: A francia republikanizmus fö kérdései A republikánus hagyomány a francia köztársasági rendszerekben. PhD dolgozat, 2001. = NAGY 2001

NASZladi GeORgINA - TILK PÉTER: Az Alkotmánybiróságra vonatkozó szabályozás átalakulása 2010 után. in GÁrdOS-Orosz FrUZSINA - SZENTE ZOLTÁN(szerk.): Alkotmánybíráskodás Magyarországon 2010 után, HVGOrac Lap- és Könyvkiadó Kft., 2015.

Negretto, Gabriel L.: The Durability of Constitutions in Changing Envirnments: Explaining Cosntitutional Replacements in Latin America. The Helen Kellogg Institute for International Studies, Working Paper No. 350, August 2008. = NEGRETTO 2008 Nemzeti alkotmányok az Európai Unióban. Wolters Kluwer, Budapest, 2016.

OPSAHL, TORKEL: The Reflection of Social Values in the Constitutional History of Norway - Some Illustrations. 15 Holdsworth L. Review, 181, 1991-1992. = OPSAHL 1991-1992

Orbán Endre: Az Alaptörvény paradoxonjai - Atmenetböl? Átmenetbe! Közjogi Szemle, 2013/2. = ORBÁN 2013

Orgad, LiAv: The Preamble in Constitutional Interpretation. Icon 2010 Vol. 8 No. 4. 
ÖZBundun, Ergun: Turkey's Constitutional Reform and the 2010 Constitutional Referendum, Mediterranean Politics, Panorama, 2011.

PAÁR ÁDÁM: Európa preambulumai. in: AnTAL AtTILA - NOVÁK ZOLTÁN SzentPÉTERi NAGy Richard (szerk.): Az Alkotmány arca Preambulum-tanulmányok. L'Harmattan, Budapest, 2011.

PAINE, THOMAS: Dissertation on the First Principles of Government, http://www.thomaspaine.org/major-works/dissertation-on-the-first-principles-ofgovernment.html $=$ PAINE 1795

PAKSY MÁTÉ: Az alkotmányértelmezés müvészete Kanadában. Iustum Aequum Salutare, 2012/1.

Petrétei JózSEF: Az alkotmányos demokrácia alapintézményei. Dialóg Campus, 2011. = PETRÉTEI 2011

PETRÉTEI JÓzSEF: Az alkotmányozó hatalom és az alkotmányosság. in: GÁRDOS-OROSZ FRUZSINA - SZENTE ZOLTÁN (szerk.): Alkotmányozás és alkotmányjogi változások Európában és Magyarországon, Nemzeti Közszolgálati Egyetem Közigazgatástudományi Kar Budapest, 2014. = PETRÉTEI 2014

PHILIPPE, XAVIER: Constitutional Review in France: the Extended Role of the Conseil constitutionnel through the New Priority Preliminary Rulings Procedure (QPC). 53 Annales U. Sci. Budapestinensis Rolando Eotvos Nominatae 3 (2012) Platón összes müvei kommentárokkal. Törvények Szerk: MiKLÓs TAMÁs, Atlantisz, 2008.

PÓCZA KÁLMÁN: Többségi demokrácia és gyenge alkotmánybíráskodás: egy elszalasztott lehetöség. (szerk.) GÁRdos-Orosz FruZsinA; SZENTE ZoltÁn: Jog és politika határán. Alkotmánybíráskodás Magyarországon 2010 után. HVG-ORAC Kiadó, 2015. 
POKOL BÉLA: Alkotmánybíráskodás - Szociológiai, politológiai és jogelméleti megközelitésekben. Kairosz Kiadó, 2014.

POLZIN, MONIKA: Constitutional identity, unconstitutional amendments and the idea of constituent power: The development of the doctrine of constitutional identity in German constitutional law. International Journal of Constitutional Law, Volume 14 Number 2, $2016=$ POLZIN 2016

POSNER, RICHARD A.: The Meaning of Judicial Self-Restraint. Indiana Law Journal, Volume 59, Issue 1, Winter 1983.

PREUSS, UlRICH K.: The Implications of ,eternity clauses”: the German Experience. Israel Law Review, 44, 2011. = PREUSS 2011

PUSZTAI FeRENC: Magyar értelmezö kéziszótár. Akadémiai Kiadó, 2009.

RÁCZ ATTILA: Az Alkotmány megváltoztatásának módozatai. In: RÁCZ ATTILA (szerk.): Jogforrások az új alkotmányban. Közgazdasági és Jogi Könyvkiadó, Budapest, 1995. = RÁCZ 1995

RASCH, BJORN ERIK - CONGLETON, ROger D.: Amendment Procedures and Constitutional Stability. in. Roger D. CONGLETON \& BirgitTA Swedenborg (szerk.): Democratic Constitutional Design and Public Policy. Analysis and Evidence. MIT Press, 2006. = RASCH - CONGLETON 2006

RAwls, JoHn: Theory of Justice, Revised Edition. the Belknap Press of Harvard University Press, Cambridge, Massachusetts, 1999. = RAWLS 1999

RENÁTA UiTZ: Can you tell when an illiberal democracy is in the making? An appeal to comparative constitutional scholarship from Hungary. International Journal of Constitutional Law, Volume 13, Issue 1, 1 January 2015.

RIXER ÁDÁM: A történeti alkotmány lehetséges jelentéstartalmai. Jogelméleti Szemle, 2011/3. = RIXER 2011 
ROZNAI, YANIV - YOLCU, SORKUN: An unconstitutional constitutional amendment - The Turkish perspective A comment on the Turkish Constitutional Court's headscarf decision. International Journal of Constitutional Law (2012) Vol. 110. No. 1. = RozNAI - YolCU 2012

RoZnAI, YANIV: Unconstitutional Constitutional Amendments The Limits of Amendment Power. Oxford Constitutional Theory, Oxford University Press, Oxford, 2017. = ROZNAI 2017

RozNAI, YANIV: Unconstitutional Constitutional Amendments-The Migration and Success of a Constitutional Idea. The American Journal of Comparative Law Vol. 61, No. $3($ Summer 2013) $=$ ROZNAI 2013

SAMAR, VInCENT J.: "Can a Constitutional Amendment Be Unconstitutional?" Oklahoma City Law Review Vol. 33 Iss. 3 (2009)

SAmU MiHÁLY: Alkotmányozás, alkotmány, alkotmányosság Korona Kiadó, 1997. = SAMU 1997

SANDAlow, TeRrance: Abstract Democracy: A Review of Ackerman 's We the People. Const. Comment. 9, 1992.

Saraiva, José Hermano: Portugália rövid története. Equinter, Budapest, 2010.

SCHMITT, CARL: Constitutional Theory. Translated and edited by Jeffrey Seitzer. Duke University Press, Durham and London, 2008. = SCHMITT 2008

SCHÖNBERGER, CHRISTOPH: Lisbon in Karlsruhe: Maastricht's Epigones At Sea. German Law Journal; 10 (2009), 8.

SCHWEITZER GÁBOR: Közjogi provizórium, jogfolytonosság, új közjogi irány $-A z$ 1919/1920-1944 közötti magyarországi alkotmányjog-tudomány vázlata, II. rész. Közjogi Szemle, 2014/2. 
Shoham, Shlomo - Lamay, NiRA: Commission for Future Generations in the Knesset: lessons learnt. In: TREMMEL, JOERG CHET (szerk.): The Handbook of Intergenerational Justice. Edward Elgar, 2006.

SIEgel, Reva B.: Heller \& Originalism's Dead hand - In Theory and Practice, Yale Law School, Yale Law School Legal Scholarship Repository. 1-1-2009. = SIEGEL 2009 Simon, Jonathan: Columbus in the Twilight Zone: Bruce Ackerman's Discovery of the Constitution. Berkeley Law, Berkeley Law Scholarship Repository, Faculty Scholarship, 1-1-1992.

SMith, EIVIND: Old and Protected? on the ,supra-constitutional” clause in the constitution of Norway. Israel Law Review, 2011, Vol. 44. = SMITH 2011

SMUK PÉTER: A szuverenitás jelképei és alkotmányos védelmük. MTA Law Working Papers 2014/37. = SMUK2014

SMUK PÉTER: Nemzetfogalom és történeti narrativa az Alaptörvényben. In: KECSKÉS GÁBOR (szerk.): Doktori Mühelytanulmányok, Széchenyi Egyetem Állam- és Jogtudományi Doktori Iskola, Győr, 2013. = SMUK 2013

SÓlyom LÁszLÓ: A jövő nemzedékek jogai és ezek képviselete a jelenben. In: JÁvoR BENEDEK (szerk.): A jövő nemzedékek jogai. kiadja: Védegylet, Rexprint Nyomda, Budapest, 2000. = SÓLYOM 2000

SÓlYOM LÁSZLÓ: Az alkotmánybíráskodás kezdetei Magyarországon. Osiris, 2001. = SÓLYOM 2001

SólyOM LÁSZLó: Normahierarchia az alkotmányban. Közjogi Szemle 2014/1. = SóLYOM 2014

SÓlyom PÉTER: Alkotmánymódositás mint alkotmánysértés? A Verfassungsdurchbrechung problémája a német alkotmányos hagyományban. in: GÁRDOs-Orosz FrUZSINA - SZENTE ZoLTÁN (szerk.): Alkotmányozás és alkotmányjogi 
változások Európában és Magyarországon, Nemzeti Közszolgálati Egyetem Közigazgatás-tudományi Kar Budapest, 2014.

SomeK, AleXANDER: The Constituent Power in a National and in a Transnational Context 3(1) Transnational Legal Theory (2012) U Iowa Legal Studies Research Paper No. 12-35.

StRAuss, DAVID A.: The Irrelevance of Constitutional Amendments. Harvard Law Review, Vol. 114, 2001.

SulyoK MÁRTON - TRÓcsÁNYi LÁszló: Preambulum. In: JAKAB ANDRÁs (szerk.): Az Alkotmány kommentárja, I., Századvég Kiadó, Budapest, 2009. = SULYOK TRÓCSÁNYI 2009

SULYOK MÁRTON: Értelem és érzelem vagy büszkeség és balitélet? Alkotmánybíráskodás és alkotmányos identitás. Fontes Juris, 1. évf., 2015/1. = SULYOK 2015

SulyoK MÁrton: Kettő az egyben? Alkotmány és identitás In: BALOGH ElemÉR (szerk.): Számadás az Alaptörvényröl, Magyar Közlöny Lap- és Könyvkiadó Kft., Budapest, 2016. = SULYOK 2016

Sulyok MÁRton: Magánszféravédelem a tisztességes eljárásban - Az alapjogsértö bizonyitás összehasonlitó alkotmányjogi vizsgálata $\mathrm{PhD}$ értekezés $=$ SULYOK 2017

SULYOK MÁRTON: Nemzeti és alkotmányos identitás a nemzeti alkotmánybíróságok gyakorlatában. In: JAKÓ MIRA ANNA (szerk.): Nemzeti identitás és alkotmányos identitás az Európai Unió és a tagállamok viszonylatában. Nemzetközi és Regionális Tanulmányok 10., Generál, Szeged, 2014. = SULYOK 2014

SulyoK MÁRton: The Crystal Ball of Constitution-Making? The Historical Constitution Clause of the Fundamental Law of Hungary and Its Effects on 
Constitutional Interpretation. 2013. november 26-án az Exeteri Egyetem jogi karán tartott előadás írásos anyaga, kézirat

SulyoK TAMÁS - SZAKÁLY ZSUZSA: Az alkotmányjogi panasz jogorvoslati jellegének bővülése. in BALOGH ElEMÉR (szerk.): Számadás az Alaptörvényről Tanulmányok a Szegedi Tudományegyetem Állam- és Jogtudományi Kar oktatóinak tollából. Magyar Közlöny Lap- és Könyvkiadó Kft., 2016.

SZABADFALVI JózSEF: Szuverenitás-koncepciók a 20. század elsö felének magyar jogirodalmában. Pro Publico Bono - Magyar Közigazgatás, I. évf., 2013/1. = SZABADFALVI 2013

SzABÓ MÁTÉ DÁNIEL: Az alapjogok információs jogi rétege. Jogi tanulmányok, 2010/1, Ünnepi konferencia az ELTE megalakulásának 375. évfordulója alkalmából (2010. április 23.) I. kötet.

SZAKÁly ZsuZSA: The Models of Constitutional Amendment in the Member States of the European Union. in: European Legal Studies and Research, International Conference of PhD Students in Law, 7th Edition, Timisoara, 2015.

SZAKÁLy ZsUZSA: A történeti alkotmány és az alkotmányos identitás az Alaptörvény tükrében. Pro Publico Bono, 2015/2. = SZAKÁLY 2015

SZAKÁLY ZSUZSA: Az alkotmánymódositási eljárás típusai az Európai Unió tagállamaiban. in: TóTH JUDIT (szerk.): Ünnepi kötet dr. Tóth Károly címzetes egyetemi tanár 70. születésnapjára, Acta Universitatis Szegediensis Acta Juridica et Politica, Tomus LXXVII., Szeged, 2015.

SZAKÁLY ZSUZSA: Az intergenerációs igazságosság megjelenése alkotmányi szinten. Pro Futuro 2017/2. szám 
SZAKÁly ZsuZSA: Human Rights, Civil Rights and Eternity Clauses. in: MARCEL SZABÓ ET AL. (szerk.): Hungarian Yearbook of International Law and European Law 2014, Eleven International Publishing, Hague, 2015.

SZAKÁLY ZSUZSA: Múlt és jövő értékei az Európai Unió tagállamaiban az alkotmány preambulumában, különös tekintettel a Nemzeti Hitvallásra. Fontes Iuris, 2017/4. szám SZAKÁly ZsUZSA: Transitional or Permanent? The Transitional Provisions of the Fundamental Law of Hungary. Days of Law 2013 Konferenciakötet, http://www.law.muni.cz/sborniky/dny_prava_2013/07_Soudy_a_soudnictvi_v_historick em_kontextu.pdf = SZAKÁLY 2013

SZALMA JÓZSEF: A történelmi/történeti és a kartális alkotmány teljességéröl és jogalkalmazási kérdéseiröl. Jogelméleti Szemle 2017/2. = SzALMA 2017

Szent István király intelmei Imre herceghez, VI. A vendégek befogadásáról és gyámolitásáról, http://mek.oszk.hu/00200/00249/00249.htm

SZEnTE Zoltán - JAKAB AndRÁs - PATYi ANDRÁs - SulyoK GÁbor: [Az Országgyülés hatáskörei] In: JAKAB ANDRÁs (szerk.): Az Alkotmány kommentárja, I., Századvég Kiadó, Budapest, 2009. = SzENTE ET AL. 2009

SZENTE ZolTÁN: A historizáló alkotmányozás problémái - a történeti alkotmány és a Szent Korona az új Alaptörvényben. Közjogi Szemle, 2011/3. = SzENTE 2011

SzENTE ZoLtÁN: Az „alkotmányellenes alkotmánymódositás” és az alkotmánymódositások bírósági felülvizsgálatának dogmatikai problémái a magyar alkotmányjogban. in: GÁRdos-Orosz FrUZSINA - SZENTE ZOLTÁN (szerk.): Alkotmányozás és alkotmányjogi változások Európában és Magyarországon, Nemzeti Közszolgálati Egyetem Közigazgatás-tudományi Kar Budapest, 2014. = SzENTE 2014 
SzEnTE Zoltán: Az Alaptörvény (2012-2015) in: JAKAB ANDRÁs - GAJDUSCHEK GYÖRGY (szerk.): A magyar jogrendszer állapota MTA Társadalomtudományi Kutatóközpont, 2016. = SZENTE 2016

SZENTE ZOLTÁN: Az Alkotmánybiróság döntése Magyarország Alaptörvényének Átmeneti rendelkezései alkotmányosságáról - Az Alaptörvény integritása és az alkotmányozó hatalom korlátai. Jogesetek Magyarázata, 2013/2. = SZENTE 2013

SZENTPÉTERI ISTVÁN: Az alkotmány társadalmi legitimitása. In: KovÁCS ISTVÁN (szerk.): Alkotmány és alkotmányosság, Akadémiai Kiadó, Budapest, 1989.

SZMODIS JENŐ: Az alkotmány magja és annak védelme. Jogelméleti Szemle, 2013/2. 1. $=$ SZMODIS 2013

SZMODIS JENŐ: Az alkotmányos történelmi vívmányok szerepéröl a normakontrollban Széljegyzetek Vörös Imre akadémiai székfoglaló elöadásához. Jogelméleti Szemle 2016/4. = SZMODIS 2016

TAKÁCS IMRE: Az alkotmány és az alkotmányosság fogalma. in: Kukorelli István (szerk.): Alkotmánytan I., Alapfogalmak, alkotmányos intézmények 2., átdolgozott kiadás, Osiris Kiadó, Budapest, 2007.

TATTAY SZILÁRD: Képtelen „képes beszéd”? A jövö nemzedékek jogainak képviseletéről. Állam- és Jogtudomány, 2016/3. = TATTAY 2016

TAYlor Young, DAniEl: How Do You Measure a Constitutional Moment? Using Algorithmic Topic Modeling To Evaluate Bruce Ackerman's Theory of Constitutional Change. 122 Yale Law Journal, 1990 (2013).

Teleki Pál országgyülési beszédei. II. kötet A „Stádium” kiadása, Budapest.

Teschner, NaAma: Official Bodies that Deal With the Needs of Future Generations and Sustainable Development. Comparative Review 3. https://www.knesset.gov.il/mmm/data/pdf/me03194.pdf 
The Collected Works of F. A. Hayek Volume XVII. The Constitution of Liberty The Definitive Edition, HAMOwy, Ronald (szerk.): The University of Chicago Press, 2011. $=$ HAYEK 2011

The Letters of Thomas Jefferson 1743-1826: To Samuel Kercheval Monticello, July 12, 1816, http://www.let.rug.nl/usa/presidents/thomas-jefferson/letters-of-thomasjefferson/jefl246.php = JEFFERSON 1816

The Oxford Handbook of Comparative Constitutional Law. (szerk.): RosENFELD, Michel - SAJÓ ANDRÁs Oxford University Press, 2012.

The Papers of James Madison. Hutchinson, William T. ET AL. (szerk.) Chicago and London: University of Chicago Press, 1962-77 (vols. 1-10); Charlottesville: University Press of Virginia, 1977- (vols. 11-) = HUTCHINSON 1977

The Papers of Thomas Jefferson. BOYD, JULIAN P. ET AL. (SZERK.): Princeton: Princeton University Press, 1950- The Founders' Constitution Volume 1, Chapter 2, Document 23, http://press-pubs.uchicago.edu/founders/documents/v1ch2s23.html The University of Chicago Press; = BOYD 1950

TLADI, DIRE: Sustainable development in international law an analysis of key enviroeconomic instruments. Pretoria University Law Press, 2007.

TóTH GÁBOR ATTILA: Túl a szövegen Értekezés a magyar alkotmányról Osiris, 2009.

TóтH JuDIT: Jogalkotástan. Egyetemi jegyzet, Szegedi Tudományegyetem, ÁJTK, 2016.

TóTH KÁROLY: Címszavak alkotmányjogi kislexikonhoz. Szeged, 2010.

TREMmel, JOERG CHET: An extended separation of powers model as the theoretical basis for the representation of future generations. http://www.futurejustice.org/wpcontent/uploads/2013/11/Paper_Future-Branch_Tremmel.pdf 
TREMMEL, JOERG CHET: Establishing intergenerational justice in national constitutions. In: Tremmel, Joerg CHeT (szerk.): The Handbook of Intergenerational Justice, Edward Elgar, 2006. = TREMMEL 2006

Tremmel, Joerg Chet: The "Generational Justice Principle": A Vision for the 21st Century. in: HeRrhausEn, AlfRED (szerk.): Gesellschaft für internationalen Dialog (Hg.): Generations in conflict, München (Piper Verlag), 2000.

TRIBL NORBERT: Az alkotmányos identitás fogalomrendszere jogelméleti megközelitésben. (megjelenés alatt)

TRIBL NORBERT: Az alkotmányos identitás természetének vizsgálata: a nemzeti és európai alkotmányos identitás,.XXXII. OTDK, Budapest, 2015. április 1.

TrIBL NoRBERT: Nincsen alkotmány identitás nélkül? A 22/2016 (XII. 5.) AB határozat jelentösége. (megjelenés alatt)

TRÓCSÁNYI LÁSZLÓ - SCHANDA BALÁZS: Bevezetés az alkotmányjogba. HVGOrac Lapés Könyvkiadó, 2015. = TRÓCSÁNYI - SCHANDA 2015

TRÓCSÁNYi LÁSZLÓ: Az alkotmányozás dilemmái Alkotmányos identitás és európai integráció. HVGOrac Lap- és Könyvkiadó, 2014. = TRÓCSÁNYI 2014

TRÓCsÁNYi LÁSZLÓ: Az alkotmányozás elvi kérdései. Acta Universitatis Szegediensis: Acta juridica et politica, 47. Tom. 1-18. Fasc. / 1996, Az alkotmányozás elvi, történeti, tételes és összehasonlító jogi problémái: a kar munkatársainak tanulmányai 1. rész. = TRÓCSÁNYI 1996

TRÓCSÁNYI LÁSZlÓ: Tagság, jogállamiság, Európai Unió. in: JAKÓ MIRA ANNA(szerk.): Nemzeti identitás és alkotmányos identitás az Európai Unió és a tagállamok viszonylatában, Generál Nyomda Kft, Szeged, 2014.

Tsebelis, GeORge: Veto Players: How Political Institutions Work. New York, Russel Sage Foundation and Princeton NJ: Princeton University Press, 2002. 
Tushnet, MARK V.: Constitutional Hardball. 37 J. Marshall L. Rev. 523-553 (2004)= TUSHNET 2004

Tushnet, MARK V.: Living in a Constitutional Moment: Lopez and Constitutional Theory. Case Western Reserve Law Review Volume 46. Issue 31996.

Tushnet, Mark V.: Peasants with pitchforks, and toilers with Twitter: Constitutional revolutions and the constituent power. International Journal of Constitutional Law (2015), Vol. 13 No. 3.

Tushnet, MARK V.: Potentially Misleading Metaphors in Comparative Constitutionalism: Moments and Enthusias. Jean Monnet Working Paper 5/04. 2004. = TUSHNET 2004

VAN PARJIS, PhILIPPE: The Disfranchisement of the Elderly, and Other Attempts to Secure Intergenerational Justice Philosophy and Public Affairs. Vol. 27, No. 4, Autumn, 1998. = VAN PARJIS 1998

VARGA ATTILA: A román alkotmányozás és alkotmánymódositás sajátosságai (néhány formai, eljárási és tartalmi elem). Közjogi Szemle, 2014/3.

VARGA CsABA: Preambulumok az alkotmányi gyakorlatban. Iustum Aequum Salutare, 2010/4. = VARGA 2010

VARGA NORBERT: Ideiglenesség és jogfolytonosság - Történeti jogintézmények szerepe a magyar alkotmányozásban. De iurisprudentia et iure publico, V. évf. 2011/2.

VARGa Zs. ANDRÁs: A mag-alkotmány védelmében. Pázmány Law Working Papers, 2011/2. = VARGA Zs. 2011

VARGA Zs. ANDRÁs: Alkotmányunk értékei. Fogalmi keretek. Iustum Aequum Salutare, 2009/1. = VARGA Zs. 2009

VARGA Zs. ANDRÁs: Eszményből bálvány? A joguralom dogmatikája. Századvég Kiadó, 2015. = VARGA Zs. 2015 
VARGA ZS. ANDRÁS: Történeti alkotmányunk vívmányai az Alaptörvény kógens rendelkezésében. Iustum Aeuum Salutare, 2016/4.

VARGHA FERENCZ: Jogfolytonosság. Jogtudományi Közlöny, 1925/9.

VArol, Ozan O., Temporary Constitutions. (April 29, 2013). 102 California Law Review 409 (2014) = VAROL 2014

VAROL, Ozan O.: The Democratic Coup d'État. Harvard International Law Journal / Vol. 53, Number 2, Summer 2012.

VERESS EMŐD: Az alkotmánymódositás céljai és eredményei Romániában. Jura 2004/1.

VincZe AtTILA ET AL, 32/A. § [Az Alkotmánybíróság] In: JAKAB ANDRÁs (szerk.): Az Alkotmány kommentárja, I., Századvég Kiadó, Budapest, 2009.

VINCZE AtTILA: Az Alkotmánybíróság határozata az Alaptörvény negyedik módositásáról Az alkotmánymódositás alkotmánybirósági kontrollja. Jogesetek Magyarázata 2013/3. = VINCZE 2013

VIROZSIL ANTAL: Magyarország nyilván- vagy közjoga mint az alkotmánya eredetétöl 1847/8-ig fennállott: történelmi szempontból tekintve s röviden elöadva - Budán, Magyar Kir. Egyetemi Nyomda betűivel, 1861. = VIROZSIL 1861

VISSY BEATRIX: Az individuális alapjogvédelem kilátásai az alkotmánybiráskodásban Merre mutat az alkotmányjogi panasz iránytüje? Magyar Közigazgatás 2012/2.

VÖRÖS IMRE: A történeti alkotmány az Alkotmánybíróság gyakorlatában. Jogtudományi Közlöny 2016/10. = VöRÖS 2016b

VÖRÖS IMRE: A történeti alkotmány az Alkotmánybíróság gyakorlatában. Közjogi Szemle, 2016/4. = VÖRÖS 2016a

VÖRÖS IMRE: Csoportkép Laokoónnal A magyar jog és az alkotmánybíráskodás vívódása az európai joggal., HVGOrac Lap- és Könyvkiadó Kft., 2012. 
VÖRÖS IMRE: Preambulumot az alkotmányhoz - de milyet? In: LAMM VANDA MAJTÉNYI BALÁZS - PAP ANDRÁS LÁSZLÓ (szerk.): Preambulum az alkotmányokban, Complex, 2011.

WALKER, NeIL: The return of constituent power: A reply to Matthias Kumm. International Journal of Constitutional Law 2016 Vol. 14.

Webster, NoAH (as "Giles Hickory”): On the Absurdity of a Bill of Rights. American Magazine (New York), December 1787, from the Debate on the Constitution (two volumes, Library of America, 1993), Volume 1. = WEBSTER 1787

Weintal, Sharon: The Challenge of Reconciling Constitutional Eternity Clauses with Populer Sovereignty: Toward Three-track Democracy in Israel as a Universal Holistic Constitutional System and Theory, Israel Law Review, 2011, Vol. 44, (449-497) = WEINTAL 2011

WESTRA, LAURA: Environmental Justice and the Rights of Unborn and Future Generations Law. Environmental Harm and the Right to Health, Earthscan, 2006. = WESTRA 2006

Williams, Jerre S: Stability and Change in Constitutional Law. Vanderbilt Law Review, Vol. 17. 1963.

WINTER, STEVEN L.: Indeterminacy and Incommensurability in Constitutional Law. California Law Review Volume 78, Issue 6, Article 2, December 1990.

Wolf, Clark: Justice and Intergenerational Debt. Intergenerational Justice Review. Vol. 2.

ZÉTÉNYI ZSOLT: Történeti alkotmányunk esélyei (részlet egy nagyobb tanulmányból). Balaton Akadémia Kiadó, 2015.

ZLINSZKY JÁnOS: Történeti alkotmányunk fejlödése 1. rész és 2. rész. Magyar Szemle Új folyam XI. 3-4., 5-6. rész = ZLINSZKY 2002 
ZSUGYÓ VIRÁG: Az Alkotmánybiróság határozata az alkotmánymódositások alkotmányossági felülvizsgálatáról Fogalmilag kizárt-e az alkotmányellenes alkotmánymódositás? Jogesetek Magyarázata Hallgatói különszám 2011. = ZSUGYÓ 2011

ZsUGYÓ VIRÁG: Az alkotmánymódositások birói felülvizsgálata Török-magyar párhuzamok. Fundamentum 2014/1-2. = ZSUGYÓ 2014

\section{Internetes források}

Az utolsó megtekintés időpontja egységesen 2018. március 11.

A jövő nemzedékek országgyülési biztosának beszámolója 2008-2009, Budapest, 2010.

A magyar zöld ombudsman volt világszerte a példakép Lukács András interjúja Catherine Pearce-el https://www.levego.hu/kapcsolodo-anyagok/a-magyar-zoldombudsman-volt-vilagszerte-a-peldakep

An EU mechanism on democracy, the rule of law and fundamental rights http://www.europarl.europa.eu/thinktank/en/document.html?reference=EPRS_IDA(201 6)579328

Az Alaptörvény hetedik módositásának javaslata http://www.parlament.hu/irom40/12458/12458.pdf

Beszámoló a jövő nemzedékek országgyülési biztosának 2010. évi tevékenyégéről, Budapest, 2011.

Beszámoló a jövő nemzedékek országgyülési biztosának 2011. évi tevékenyégéről Beszámoló az alapvető jogok biztosának és helyetteseinek 2012. évi tevékenységéről, Alapvető Jogok Biztosának Hivatala, 2013. 
Beszámoló az alapvető jogok biztosának és helyetteseinek tevékenységéről 2013, Alapvető Jogok Biztosának Hivatala, 2014.

Beszámoló az alapvető jogok biztosának és helyetteseinek tevékenységéről 2014, Alapvető Jogok Biztosának Hivatala, 2015.

Beszámoló az alapvető jogok biztosának és helyetteseinek tevékenységéröl 2015, Alapvető Jogok Biztosának Hivatala, 2016.

BLOOM, DAN: Young voters wanted Brexit the least - and will have to live with it the longest http://www.mirror.co.uk/news/uk-news/young-voters-wanted-brexit-least-8271517

BoOThroyd Rojas, RACHAEL: Tentative Talks Begin Between Venezuelan Government and Opposition https://venezuelanalysis.com/news/13363

Council on Environmental Quality https://www.whitehouse.gov/administration/eop/ceq DER, BERTIL EMRAH: Populism and the Turkish Constitutional Court: the Game Broker, the Populist and the Popular, VerfBlog http://verfassungsblog.de/populism-and-theturkish-constitutional-court-the-game-broker-the-populist-and-the-popular/

DEZSÖ ANDRÁS: Kilenc órán át tartották blokád alatt a venezuelai parlamentet http://index.hu/kulfold/2017/07/06/kilenc_oran_at_tartottak_blokad_alatt_a_venezuelai _parlamentet/

DRAVECZKI-URY ÁDÁM: Venezuela: diktatúra vagy polgárháború? http://www.honvedelem.hu/cikk/64973

European Neighbourhood Policy And Enlargement Negotiations https://ec.europa.eu/neighbourhood-enlargement/policy/conditions-

membership/chapters-of-the-acquis_en

Fő fenntartások Magyarország Alaptörvényének negyedik módosításával kapcsolatban https://tasz.hu/files/tasz/imce/fo_fenntartasok_magyarorszag_alaptorvenyenek_negyedi k_modositasaval_kapcsolatban_fin.pdf

GALIERO, EMMANUEL: Révision constitutionnelle par référendum: les éclairages d'un constitutionnaliste http://www.lefigaro.fr/politique/le-scan/2018/01/29/2500120180129ARTFIG00265-revision-constitutionnelle-par-referendum-les-eclairages-dun-constitutionnaliste.php 
GALTIER, LUdOVIC: Réforme constitutionnelle : les 5 mesures phares prévues par Macron http://www.rtl.fr/actu/politique/reforme-constitutionnelle-les-5-mesures-pharesprevues-par-macron-7790235836

Gettleman, JefFrey: Kenyans Approve New Constitution, New York Times http://www.nytimes.com/2010/08/06/world/africa/06kenya.html?mcubz=3

Guarding our Future How to include future generations in policy making http://www.futurejustice.org/wp-

content/uploads/2013/04/Ombudspersons_for_Future_Generations_Broshure_WFC.pdf; Gungen, DenIZ - BAg, Tolga: The 2017 Turkish Constitutional Referendum. http://www.apcoworldwide.com/blog/detail/apcoforum/2017/04/19/the-2017-turkishconstitutional-referendum

Helm, ToBy: Poll reveals young remain voters reduced to tears by Brexit result: http://www.theguardian.com/politics/2016/jul/02/brexit-referendum-voters-survey http://public.mkab.hu/dev/dontesek.nsf/0/f6a5c5aa83e6483fc1257be3001b8de8/\$FILE/I V_1198_0_2013_inditvany_anonim.pdf http://www.futurejustice.org/ http://www.government.is/constitution/ http://www.intergenerationaljustice.org/ http://www.pce.parliament.nz/about-us/our-role http://www.pce.parliament.nz/about-us/the-commissioner http://www.presidency.gov.cy/presidency/presidency.nsf/DMLindex_en/DMLindex_en ?OpenDocument

http://www.senate.gov/civics/constitution_item/constitution.htm http://www.venice.coe.int/WebForms/documents/by_opinion.aspx?lang=EN https://index.hu/kulfold/2017/12/18/a_romanoknal_felvetodott_a_kiralysag_visszaallita $\mathrm{sa} /$

https://www.ajbh.hu/jelenlegi-biztos-eshelyettesek;jsessionid=F387B122D9FEFC38ABA3867FB155A4D8 https://www.worldfuturecouncil.org/ Intergenerational solidarity and the needs of future generations Report of the SecretaryGeneral https://sustainabledevelopment.un.org/content/documents/2006future.pdf Internetes források 
Irish voters reject EU treaty http://www.theguardian.com/world/2008/jun/13/ireland Kirk, Ashley - Coles, Malcolm - Krol, Charlotte: EU referendum results and maps: Full breakdown and find out how your area voted. http://www.telegraph.co.uk/news/2016/06/23/leave-or-remain-eu-referendum-resultsand-live-maps/

M. LÁSZLÓ FERENC: Törvénytervezet a jövő nemzedékek ombudsmanjáról: Gyámhatóság.

2007/15. http://magyarnarancs.hu/belpol/torvenytervezet_a_jovo_nemzedekek_ombudsmanjarol_ gyamhatosag-66964

Ma még láthatatlan alkotmány http://nol.hu/archivum/archiv-431485-240727

Már nem olyan vonzó az amerikai alkotmány http://multkor.hu/20120222_mar_nem_olyan_vonzo_az_amerikai_alkotmany

MilÁNKOVICH ANDRÁS - SzENTGÁli-TóTH BoldizSÁR: Vívmányok a gyakorlatban. http://arsboni.hu/vivmanyok-a-gyakorlatban/

Models for Protecting the Environment for Future Generations. Science and Environmental Health Network The International Human Rights Clinic at Harvard Law School, October 2008, http://www.law.harvard.edu/programs/hrp

NAGY BoLDIZSÁR: Védőbeszéd a jövő nemzedékekért http://ligetmuhely.com/nagy-ajovo-nemzedekekert/

NOLT, JOHN: Arguments for and against Obligations for Future Generations. http://web.utk.edu/ nolt/courses/346/futurgen.htm

O'MAHONY, CONOR: Having regard for our children http://www.irishexaminer.com/viewpoints/analysis/having-regard-for-our-children208565.html

Réforme de la Constitution: le spectre du référendum https://www.publicsenat.fr/article/politique/reforme-de-la-constitution-le-spectre-dureferendum-81858

SAAD, LYDIA: Americans Would Swap Electoral College for Popular Vote http://www.gallup.com/poll/150245/Americans-Swap-Electoral-College-Popular-

Vote.aspx

SCAlia, Antonin: Common-Law Courts in a Civil-Law System: The Role of United States Federal Courts in Interpreting the Constitution and Laws, The Tanner Lectures on 
Human Values, Delivered at Princeton University March 8 and 9, 1995. http://tannerlectures.utah.edu/_documents/a-to-z/s/scalia97.pdf

SHAHEEN, KAREEM: Erdoğan clinches victory in Turkish constitutional referendum https://www.theguardian.com/world/2017/apr/16/erdogan-claims-victory-in-turkishconstitutional-referendum

Shuster, SIMON: The UK's Old Decided for the Young in the Brexit Vote http://time.com/4381878/brexit-generation-gap-older-younger-voters/

SiEYÉS, EMMANUEL-JosePH: What is the Third Estate? 1789, http://pages.uoregon.edu/dluebke/301ModernEurope/Sieyes3dEstate.pdf

SÓLYOM LÁSzLÓ: Alkotmány és alkotmányos kultúra Magyarországon. http://tte.hu/solyom-laszlo-alkotmany-es-alkotmanyos-kultura-magyarorszagon/ SÓlYOM LÁSZLÓ: Az alkotmánybírák nem másolnak, hanem gondolkodnak http://mandiner.hu/cikk/20130207_solyom_az_alkotmanybirak_nem_masolnak_hanem _gondolkodnak

SPARROW, AlEX: Girondin Constitution. http://www.democracyinprinciple.com/blog/articles/girondin-constitution/

Szülői szavazati jog - érvek pro és kontra http://alkotmany.reblog.hu/szuloiszavazatijog The High Commissioner for Future Generations: the Future We Want Center for International, Environmental Law, World Future Council http://www.worldfuturecouncil.org/inc/uploads/2016/01/WFC_CIEL_2012_High_Com missioner_for_Future_Generations.pdf

ThORTON, LiAM: The Children's Referendum: the Oireachtas Debates http://humanrights.ie/constitution-of-ireland/childrens-amendment-blog-carnival-theoireachtas-debates/

Turkey referendum: Key reactions. http://www.bbc.com/news/world-europe-39615403 Turkey's constitution: 18 current and proposed changes http://www.trtworld.com/referendum/18-ways-the-turkish-constitution-might-change334921

VAJDA ZoltÁN: Republikanizmus az Amerikai Egyesült Államok 18-19. századi történetében. http://www.aetas.hu/1998_4/republikanizmus.htm 


\section{Hivatkozott jogszabályok, jogesetek jegyzéke}

\section{Alkotmánybírósági határozatok}

23/1990 (X. 31.) AB határozat

1359/B/1990. AB határozat

11/1992. (III. 5.) AB határozat

30/1992. (V. 26.) AB határozat

10/1993. (II. 27.) AB határozat

2/1994. (I. 14.) AB határozat

23/1994. (IV. 29.) AB végzés

46/1994. (X. 21.) AB határozat

293/B/1994. AB végzés

1/1995. (II. 8.) AB határozat

4/1997. (I. 22.) AB határozat

27/1995. (V. 15.) AB határozat

30/1997. (IV. 29.) AB határozat

515/B/1997. AB határozat

1260/B/1997 AB határozat

16/1998. (V. 8.) AB határozat

4/1999. (III. 31.) AB határozat

18/2000. (VI. 6.) AB határozat

167/B/2000. AB határozat

31/2001. (VII. 11.) AB határozat

2/2002. (I. 25.) AB határozat

801/B/2002. AB határozat 
41/2003. (VII. 2.) AB határozat

3/2004. (II. 17.) AB határozat

14/2004. (V. 7.) AB határozat

673/B/2004. AB határozat

3/2006. (II. 8.) AB határozat

12/2006. (IV. 24.) AB határozat

51/2007. (IX. 15.) AB határozat

90/2007. (XI. 14.) AB határozat

32/2008. (III. 12.) AB határozat

131/2008. (XI. 3.) AB határozat

61/2011 (VII. 13.) AB határozat

22/2012. (V. 11.) AB határozat

33/2012. (VII. 17.) AB határozat

45/2012. (XII. 29.) AB határozat

1/2013 (I. 7.) AB határozat

6/2013. (III. 1.) AB határozat

12/2013 (V. 24.) AB határozat

21/2013 (VII. 19.) AB határozat

31/2013. (X. 28.) AB határozat

27/2013. (X. 9.) AB határozat

3160/2013. (VII. 24.) AB végzés

28/2014. (IX. 29.) AB határozat

29/2014. (IX. 30.) AB határozat

34/2014. (XI. 14.) AB határozat

35/2014. (XII. 18.) AB határozat 
3024/2014. (II. 11.) AB végzés

16/2015. (VI. 5.) AB határozat

17/2015 (VI. 5.) AB határozat

3074/2015. (IV. 23.) AB végzés

3081/2015. (V. 8.) AB határozat

22/2016 (XII. 5.) AB határozat

3038/2016. (III. 3.) AB határozat

3127/2017. (V. 30.) AB végzés

3218/2016. (XI. 14.) AB végzés

12/2017. (VI. 19.) AB határozat

17/2017. (VII. 18.) AB határozat

3070/2017. (IV. 19.) AB határozat

3191/2017 (VII. 21.) AB határozat

\section{A Velencei Bizottság döntései}

CDL-INF(1996)002

CDL-INF(2001)15

CDL-AD(2002)001

CDL-AD(2007)047

CDL-AD(2010)001

CDL-AD(2011)001

CDL-AD(2011)016

CDL-AD(2012)001

CDL-AD(2012)008

CDL-AD(2012)010

CDL-AD(2012)020 
CDL-AD(2013)010

CDL-AD(2013)012

CDL-AD(2013)029

CDL-PI(2015)023

CDL-AD(2017)005

CDL-AD(2017)010

CDL-AD(2017)015

\section{Nemzeti alkotmányok}

A vizsgált alkotmányok forrásszövegei az Európai Unió tagállamai esetében a Nemzeti Alkotmányok az Európai Unióban (2016, Wolters Kluwer) könyvböl kerültek feldolgozásra, a többi ország alkotmánya egységesen a Constitute Project (www.constituteproject.org) internetes oldalon hozzáférhető hatályos forrásszövegekből, valamint az adott ország parlamentjének angol nyelvü felületeiről származnak.

\section{Külföldi bírói gyakorlat}

Brown v. Board of Education of Topeka, 347 U.S. 483 (1954)

Dissenting Opinion of Judge Weeramantry Reports of Judgments, Advisory Opinions and Orders Case Concerning the Gabcikovo-Nagymaros Project (Hungary-Slovakia) Judgment of 25 September 1997.

Dissenting Opinion of Judge Weeramantry Threat or Use of Nuclear Weapons Farooque v. Government of Bangladesh International Court of Justice Report of Judgments, Advisory Opinions and Orders Legality of the Threat or Use of Nuclear Weapons Advisory Opinion of 8 July 1996 
Internationale Handelsgesellschaft $\mathrm{GmbH}$ kontra Einfuhr- und Vorratsstelle für Getreide und Futtermittel.

Jacobson v. Massachusetts, 197 U.S. 11 (1905)

James Obergefell, et al., Petitioners v. Richard Hodges, Director, Ohio Department of Health, et al. 2015

Jane Roe, et al. v. Henry Wade, District Attorney of Dallas County, 1973

Kesavananda Bharati ... vs State Of Kerala And Anr on 24 April, 1973

Marbury v Madison 5 U.S. 137 (1803)

Minors Oposa v. Secretary of the Department of Environment and Natural Resources

Terminiello v. City of Chicago

\section{Hivatkozott jogszabályok}

1989. évi XXXI törvény az Alkotmány módosításáról

a Magyar Köztársaság hosszú távú fenntartható fejlődésével kapcsolatos tervezési és egyeztetési folyamat feladatairól szóló 100/2007. (XI. 14.) országgyülési határozat 5. pont

Magyarország Alaptörvénye (2011. április 25.)

\section{Nemzetközi jogi dokumentumok}

2749 (XXV). Declaration of Principles Governing the Sea-Bed and the Ocean Floor, and the Subsoil Thereof, beyond the Limits of National Jurisdiction

Convention Concerning the Protection of the World Cultural and Natural Heritage Adopted by the General Conference at its seventeenth session Paris, 16 November 1972; Report of the United Nations Conference on Environment and Development, (Rio de Janeiro, 3-14 June 1992) 
Lisszaboni Szerződés az Európai Unióról szóló szerződés és az Európai Közösséget létrehozó szerződés módosításáról 


\section{Mellékletek}

\begin{tabular}{|c|c|c|c|c|c|c|c|c|}
\hline Ország & $\begin{array}{l}\text { Többségi } \\
\text { rendszer }\end{array}$ & $\begin{array}{c}\text { Kétkamarás } \\
\text { rendszer }\end{array}$ & $\begin{array}{c}\text { Kezdemé } \\
\text { nyezés } \\
\text { joga }\end{array}$ & $\begin{array}{c}\text { Késleltetési } \\
\text { eljárás }\end{array}$ & $\begin{array}{l}\text { Alkotmány } \\
\text { ozó } \\
\text { nemzetgyül } \\
\text { és }\end{array}$ & $\begin{array}{c}\text { Morató } \\
\text { rium }\end{array}$ & $\begin{array}{c}\text { Népszava } \\
\text { zás }\end{array}$ & Egyéb \\
\hline Ausztria & $\mathrm{x}$ & $\mathrm{x}$ & & & & & $S$ & \\
\hline Belgium & $\mathrm{x}$ & $\mathrm{x}$ & & $\mathrm{x}$ & & & & $E$ \\
\hline Bulgária & $\mathrm{x}$ & & $\mathrm{x}$ & $\mathrm{x}$ & $S$ & & & \\
\hline Ciprus & $\mathrm{x}$ & & & & & & & \\
\hline $\begin{array}{c}\text { Csehorsz } \\
\text { ág }\end{array}$ & $\mathrm{x}$ & $\mathrm{x}$ & & & & & & \\
\hline Dánia & & & & $\mathrm{x}$ & & & $\mathrm{x}$ & \\
\hline $\begin{array}{l}\text { Egyesült } \\
\text { Királyság }\end{array}$ & & & & & & & & \\
\hline $\begin{array}{c}\text { Észtorszá } \\
\mathrm{g}\end{array}$ & $\mathrm{x}$ & & $\mathrm{x}$ & $\mathrm{x}$ & & S & S & E \\
\hline $\begin{array}{c}\text { Finnorszá } \\
\mathrm{g}\end{array}$ & $\mathrm{x}$ & & & $\mathrm{x}$ & & & & E \\
\hline $\begin{array}{c}\text { Franciaor } \\
\text { szág }\end{array}$ & $\mathrm{x}$ & $\mathrm{x}$ & $\mathrm{x}$ & & & & $S$ & E \\
\hline $\begin{array}{l}\text { Görögors } \\
\text { zág }\end{array}$ & $\mathrm{x}$ & & & $\mathrm{x}$ & & $\mathrm{x}$ & & E \\
\hline Hollandia & $\mathrm{x}$ & $\mathrm{x}$ & & $\mathrm{x}$ & & & & \\
\hline $\begin{array}{l}\text { Horvátor } \\
\text { szág }\end{array}$ & $\mathrm{x}$ & & $\mathrm{x}$ & & & & & \\
\hline Írország & & $\mathrm{x}$ & & & & & $\mathrm{x}$ & \\
\hline $\begin{array}{l}\text { Lengyelo } \\
\text { rszág }\end{array}$ & $\mathrm{x}$ & $\mathrm{x}$ & $\mathrm{x}$ & $\mathrm{x}$ & & & $S$ & \\
\hline $\begin{array}{c}\text { Lettorszá } \\
\mathrm{g}\end{array}$ & $\mathrm{x}$ & & $\mathrm{x}$ & & & & S & \\
\hline Litvánia & $\mathrm{x}$ & & $\mathrm{x}$ & $\mathrm{x}$ & & $\mathrm{x}$ & $S$ & \\
\hline $\begin{array}{c}\text { Luxembu } \\
\text { rg }\end{array}$ & $\mathrm{x}$ & & & $\mathrm{x}$ & & $S$ & $S$ & \\
\hline $\begin{array}{l}\text { Magyaror } \\
\text { szág }\end{array}$ & $\mathrm{x}$ & & $\mathrm{x}$ & & & & & \\
\hline Málta & $\mathrm{x}$ & & & & & & $S$ & \\
\hline $\begin{array}{l}\text { Németors } \\
\text { zág }\end{array}$ & $\mathrm{x}$ & $\mathrm{x}$ & & & & & & \\
\hline $\begin{array}{l}\text { Olaszorsz } \\
\text { ág }\end{array}$ & $\mathrm{x}$ & $\mathrm{x}$ & & $\mathrm{x}$ & & & $S$ & \\
\hline $\begin{array}{c}\text { Portugáli } \\
\text { a }\end{array}$ & $\mathrm{x}$ & & $\mathrm{x}$ & & & $\mathrm{x}$ & & E \\
\hline Románia & $\mathrm{x}$ & $\mathrm{x}$ & $\mathrm{x}$ & & & & $\mathrm{x}$ & E \\
\hline $\begin{array}{l}\text { Spanyolo } \\
\text { rszág }\end{array}$ & $\mathrm{x}$ & $\mathrm{x}$ & $\mathrm{S}$ & $\mathrm{x}$ & S & & $\mathrm{S}$ & E \\
\hline $\begin{array}{l}\text { Svédorsz } \\
\text { ág }\end{array}$ & & & & $\mathrm{x}$ & & & S & E \\
\hline
\end{tabular}




\begin{tabular}{|l|l|l|l|l|l|l|l|}
\hline Szlovákia & $\mathrm{x}$ & & & & & & \\
\hline Szlovénia & $\mathrm{x}$ & & $\mathrm{x}$ & & & & $\mathrm{S}$ \\
\hline
\end{tabular}

\begin{tabular}{|l|l|}
\hline $\mathrm{x}$ & $\begin{array}{l}\text { van az adott országban ilyen eljárási eszköz az alkotmánymódosítás során } \\
\text { alapesetben }\end{array}$ \\
\hline $\mathrm{S}$ & $\begin{array}{l}\text { speciális esetben igénybe vehető/veendö eljárási eszköz } \\
\text { pl. megváltoztathatatlan részek, a többi kategóriába nem illeszkedő } \\
\text { kiegészítő szabályok }\end{array}$ \\
\hline Egyéb & $\begin{array}{l}\text { Szlovénia az egyetlen vizsgált ország, ahol kétkamarás a parlament, de csak } \\
\text { az egyik kamarának kell elfogadnia az alkotmánymódosítást }\end{array}$ \\
\hline & Nem értelmezhető \\
\hline
\end{tabular}

2. táblázat. Az egyes eljárási eszközök elöfordulása az Európai Unió tagállamainak alkotmányaiban.

A táblázat az egyes eljárási eszközök elöfordulását mutatja az európai uniós tagállami alkotmányokban (forrás: Nemzeti alkotmányok az Európai Unióban, saját feldolgozás). 


\begin{tabular}{|c|c|c|}
\hline Ország & $\begin{array}{l}\text { Múltra utaló } \\
\text { rendelkezés }\end{array}$ & $\begin{array}{l}\text { Jövőre utaló } \\
\text { rendelkezése }\end{array}$ \\
\hline \multicolumn{3}{|l|}{ Ausztria } \\
\hline \multicolumn{3}{|l|}{ Belgium } \\
\hline \multicolumn{3}{|l|}{ Bulgária } \\
\hline \multicolumn{3}{|l|}{ Ciprus } \\
\hline Csehország & $\mathrm{x}$ & $\mathrm{x}$ \\
\hline \multicolumn{3}{|l|}{ Dánia } \\
\hline \multicolumn{3}{|l|}{ Egyesült Királyság } \\
\hline Észtország & $\mathrm{x}$ & $\mathrm{x}$ \\
\hline \multicolumn{3}{|l|}{ Finnország } \\
\hline Franciaország & $\mathrm{x}$ & \\
\hline \multicolumn{3}{|l|}{ Görögország } \\
\hline \multicolumn{3}{|l|}{ Hollandia } \\
\hline Horvátország & $\mathrm{x}$ & $\mathrm{x}$ \\
\hline Írország & $\mathrm{x}$ & \\
\hline Lengyelország & $\mathrm{x}$ & $\mathrm{x}$ \\
\hline Lettország & $\mathrm{x}$ & $\mathrm{x}$ \\
\hline Litvánia & $\mathrm{x}$ & \\
\hline \multicolumn{3}{|l|}{ Luxemburg } \\
\hline Magyarország & $\mathrm{x}$ & $\mathrm{x}$ \\
\hline \multicolumn{3}{|l|}{ Málta } \\
\hline \multicolumn{3}{|l|}{ Németország } \\
\hline \multicolumn{3}{|l|}{ Olaszország } \\
\hline Portugália & $\mathrm{x}$ & $\mathrm{x}$ \\
\hline \multicolumn{3}{|l|}{ Románia } \\
\hline Spanyolország & & $\mathrm{x}$ \\
\hline \multicolumn{3}{|l|}{ Svédország } \\
\hline Szlovákia & $\mathrm{x}$ & $\mathrm{x}$ \\
\hline Szlovénia & $\mathrm{x}$ & \\
\hline
\end{tabular}

\section{nem értelmezhető}

3. táblázat. A múlt és a jövő megjelenése az Európai Unió tagállamainak alkotmányaiban.

A táblázat a múlt és jövő megjelenését mutatja az Európai Unió tagállami alkotmányok preambulumaiban (forrás: Nemzeti alkotmányok az Európai Unióban, saját feldolgozás). 


\begin{tabular}{|c|c|c|}
\hline Elv & $\begin{array}{c}\text { Megjelenés más EU-s } \\
\text { országok } \\
\text { örökkévalósági } \\
\text { klauzuláiban }\end{array}$ & Ország \\
\hline Szabadságjogok & igen & $\begin{array}{c}\text { Románia } \\
\text { Németország }\end{array}$ \\
\hline Hatalommegosztás & igen & $\begin{array}{c}\text { Görögország } \\
\text { Portugália }\end{array}$ \\
\hline Köztársasági államforma & igen & $\begin{array}{c}\text { Franciaország } \\
\text { Görögország } \\
\text { Olaszország } \\
\text { Németország } \\
\text { Portugália } \\
\text { Románia }\end{array}$ \\
\hline Közjogi autonómiák tisztelete & hasonló & $\begin{array}{l}\text { Portugália: az Azori-szigetek } \\
\text { és Madeira politikai és } \\
\text { közigazgatási autonómiája }\end{array}$ \\
\hline Vallásszabadság & hasonló & $\begin{array}{c}\text { Portugália: állam és egyház } \\
\text { elválasztása } \\
\text { Görögország: lelkiismereti } \\
\text { szabadság }\end{array}$ \\
\hline Törvényes hatalomgyakorlás & nincs & \\
\hline Parlamentarizmus & igen & Görögország \\
\hline Jogegyenlőség & hasonló & $\begin{array}{c}\text { Görögország: törvény elötti } \\
\text { egyenlőség }\end{array}$ \\
\hline Bírói hatalom elismerése & igen & $\begin{array}{c}\text { Portugália } \\
\text { Görögország } \\
\text { Románia }\end{array}$ \\
\hline $\begin{array}{l}\text { Velünk élő nemzetiségek } \\
\text { védelme }\end{array}$ & nincs & \\
\hline
\end{tabular}

4. táblázat. A történeti alkotmány vívmányai és az örökkévalósági klauzulák közötti kapcsolódási pontok forrás: saját feldolgozás 


\begin{tabular}{|c|c|c|c|c|c|c|}
\hline Csehország & Franciaország & Görögország & Olaszország & Németország & Portugália & Románia \\
\hline \multirow[t]{5}{*}{$\begin{array}{l}\text { demokratikus } \\
\text { jogállam } \\
\text { lényeges elemei }\end{array}$} & $\begin{array}{l}\text { köztársasági } \\
\text { államforma }\end{array}$ & $\begin{array}{l}\text { parlamentáris } \\
\text { köztársaság mint } \\
\text { kormányforma }\end{array}$ & $\begin{array}{l}\text { köztársasági } \\
\text { államforma }\end{array}$ & $\begin{array}{l}\text { demokratikus és szociális } \\
\text { szövetségi állam }\end{array}$ & $\begin{array}{l}\text { köztársasági } \\
\text { államforma }\end{array}$ & $\begin{array}{l}\text { köztársasági } \\
\text { kormányforma }\end{array}$ \\
\hline & $\begin{array}{l}\text { terület } \\
\text { sérthetetlensége }\end{array}$ & $\begin{array}{l}\text { törvényhozó } \\
\text { hatalom a } \\
\text { Parlamenté és a } \\
\text { köztársasági } \\
\text { elnöké }\end{array}$ & & $\begin{array}{l}\text { Szövetség tartományokra } \\
\text { való felosztása }\end{array}$ & $\begin{array}{c}\text { nemzeti függetlenség } \\
\text { és egység }\end{array}$ & $\begin{array}{c}\text { az állam egységes és } \\
\text { oszthatatlan }\end{array}$ \\
\hline & & $\begin{array}{l}\text { Végrehajtó } \\
\text { hatalom a } \\
\text { köztársasági } \\
\text { elnöké és a } \\
\text { kormányé }\end{array}$ & & $\begin{array}{l}\text { a tartományok alapvető } \\
\text { közremüködése a } \\
\text { törvényhozásban }\end{array}$ & $\begin{array}{l}\text { az államhatalmi ágak } \\
\text { elválasztása és } \\
\text { kölcsönös függősége }\end{array}$ & a terület integritása \\
\hline & & $\begin{array}{l}\text { Bírói hatalom a } \\
\text { bíróságoké }\end{array}$ & & $\begin{array}{l}\text { (3) A törvényhozást az } \\
\text { alkotmányos rend, a } \\
\text { végrehajtó hatalmat és az } \\
\text { igazságszolgáltatást a } \\
\text { törvény és jog köti. }\end{array}$ & a bírói függetlenség & $\begin{array}{l}\text { igazságszolgáltatás } \\
\text { függetlensége }\end{array}$ \\
\hline & & $\begin{array}{c}\text { személyiség } \\
\text { szabad } \\
\text { kibontakoztatása }\end{array}$ & & ellenállási jog & $\begin{array}{c}\text { a véleménynyilvánítás } \\
\text { és a politikai } \\
\text { szervezetek } \\
\text { sokfélesége }\end{array}$ & $\begin{array}{c}\text { állampolgárok } \\
\text { alapvető jogainak és } \\
\text { azabdságainak vagy } \\
\text { ezek biztosítékainak } \\
\text { védelme }\end{array}$ \\
\hline
\end{tabular}




\begin{tabular}{|c|c|c|c|c|c|c|}
\hline Csehország & Franciaország & Görögország & Olaszország & Németország & Portugália & Románia \\
\hline & & $\begin{array}{c}\text { személyi } \\
\text { szabadság } \\
\text { sérthetetlensége }\end{array}$ & & $\begin{array}{c}\text { emberi jogok } \\
\text { sérthetetlensége és } \\
\text { elidegeníthetetlensége }\end{array}$ & $\begin{array}{l}\text { a munkavállalók } \\
\text { jogai, bizottságai és a } \\
\text { szakszervezetek }\end{array}$ & politikai pluralizmus \\
\hline & & $\begin{array}{c}\text { lelkiismereti } \\
\text { szabadság } \\
\text { sérthetetlensége }\end{array}$ & & $\begin{array}{l}\text { alapjogok közvetlenül } \\
\text { hatályosak, kötik az } \\
\text { államhatalami ágakat }\end{array}$ & $\begin{array}{l}\text { az állampolgárok } \\
\text { jogai, szabadságai és } \\
\text { azok biztosítékai }\end{array}$ & hivatalos nyelv \\
\hline & & $\begin{array}{l}\text { törvény előtti } \\
\text { egyenlőség }\end{array}$ & & $\begin{array}{l}\text { népszuverenitás, } \\
\text { hatalomgyakorlás formái }\end{array}$ & $\begin{array}{l}\text { állam és egyház } \\
\text { elválasztása }\end{array}$ & \\
\hline & & közhivatal viselése & & $\begin{array}{l}\text { Az emberi méltóság } \\
\text { sérthetetlenségének } \\
\text { védelme }\end{array}$ & $\begin{array}{l}\text { termelési eszközök } \\
\text { tulajdona }\end{array}$ & \\
\hline & & $\begin{array}{l}\text { nemesi vagy más } \\
\text { megkülönböztető } \\
\text { címek tilalma }\end{array}$ & & & vegyes gazdálkodás & \\
\hline
\end{tabular}




\begin{tabular}{|c|c|c|c|c|c|c|}
\hline Csehország & Franciaország & Görögország & Olaszország & Németország & Portugália & Románia \\
\hline & & $\begin{array}{l}\text { emberi méltóság } \\
\text { tiszteletben tartása } \\
\text { és védelme }\end{array}$ & & & bírói felülvizsgálat & \\
\hline & & & & & $\begin{array}{c}\text { a helyi } \\
\text { önkormányzatok } \\
\text { önrendelkezési joga }\end{array}$ & \\
\hline & & & & & $\begin{array}{c}\text { általános, közvetlen, } \\
\text { titkos és rendszeres } \\
\text { választások, arányos } \\
\text { képviselet }\end{array}$ & \\
\hline & & & & & $\begin{array}{c}\text { az Azori-szigetek és } \\
\text { Madeira politikai és } \\
\text { közigazgatási } \\
\text { autonómiája }\end{array}$ & \\
\hline
\end{tabular}

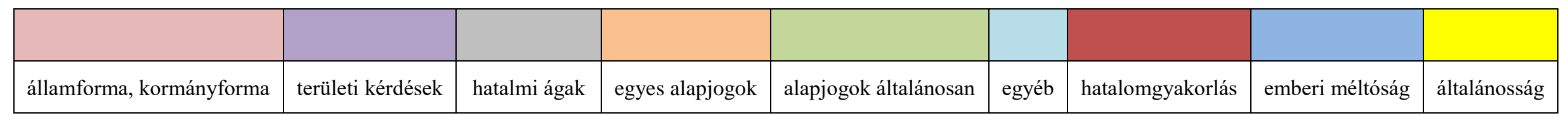

5. táblázat. Az örökkévalósági klauzulák megjelenése az Európai Unió tagállamainak alkotmányaiban.

Ez a táblázat bemutatja, hogy az európai uniós tagállami alkotmányokban mely országok és milyen rendelkezéseket tekintettek olyan fontosnak, hogy örökkévalósági klauzulaként konzerválták a jövő törvényalkotói számára (forrás: Nemzeti alkotmányok az Európai Unióban, saját feldolgozás). 


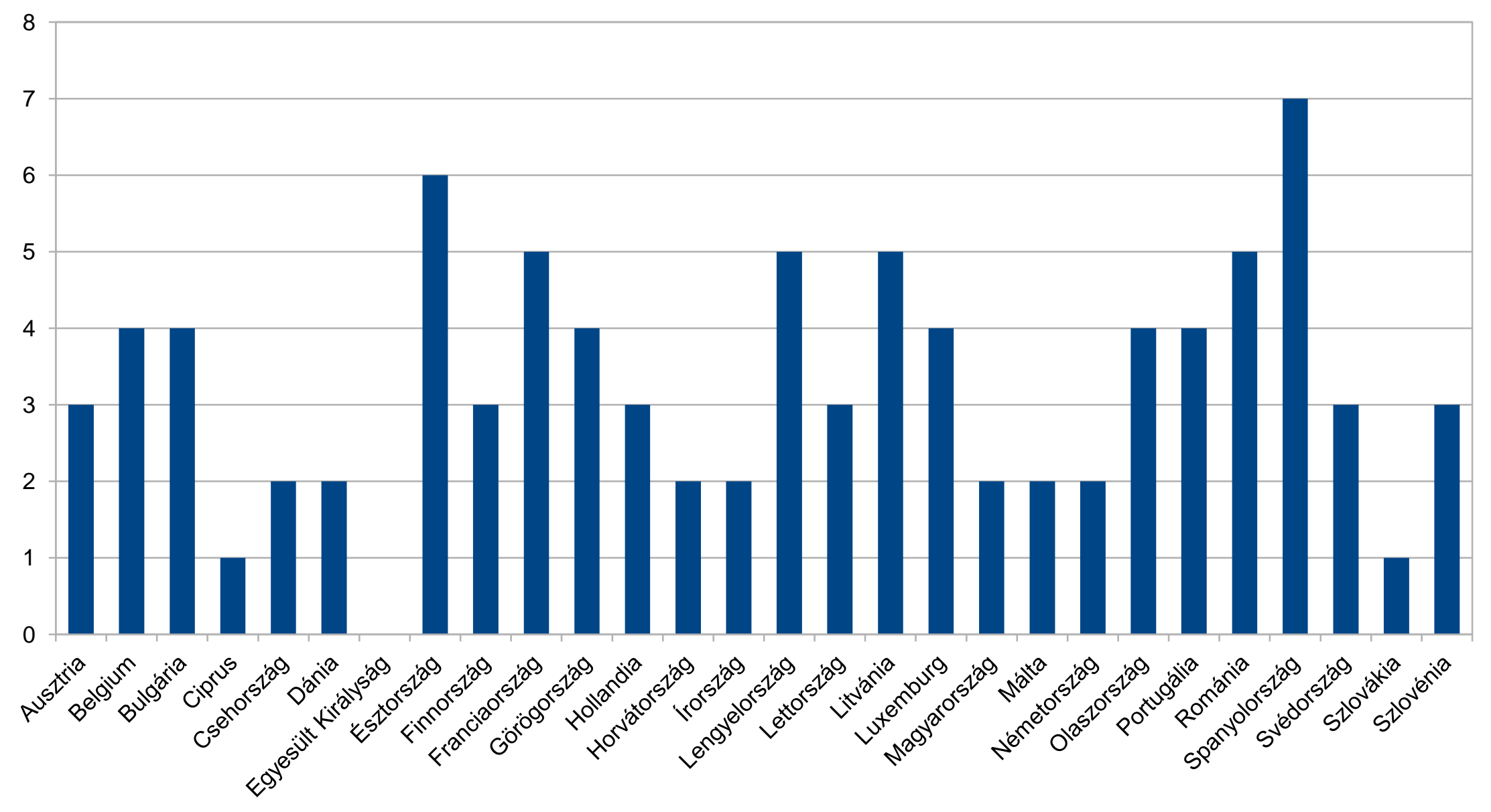

2. ábra. Az egyes eljárási eszközök előfordulásának gyakorisága az Európai Unió tagállamainak alkotmányaiban.

A grafikon az egyes eljárási eszközök számát mutatja országonként (forrás: Nemzeti alkotmányok az Európai Unióban, saját feldolgozás) 